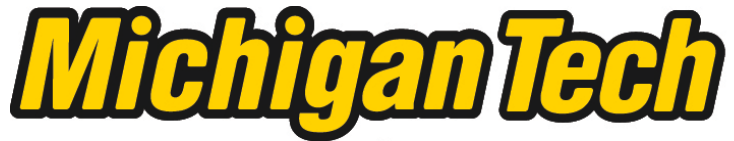 \\ Michigan Technological University Create the Future Digital Commons @ Michigan Tech
}

\section{Technology, mining methods and landscapes of a placer mining district in Fairbanks, Alaska, 1900-1930}

John P. Baeten

Michigan Technological University

Follow this and additional works at: https://digitalcommons.mtu.edu/etds

Part of the Archaeological Anthropology Commons

Copyright 2012 John P. Baeten

\section{Recommended Citation}

Baeten, John P., "Technology, mining methods and landscapes of a placer mining district in Fairbanks, Alaska, 1900-1930", Master's Thesis, Michigan Technological University, 2012.

https://doi.org/10.37099/mtu.dc.etds/305

Follow this and additional works at: https://digitalcommons.mtu.edu/etds

Part of the Archaeological Anthropology Commons 


\title{
THE TECHNOLOGY, MINING METHODS AND LANDSCAPES OF A PLACER MINING DISTRICT IN FAIRBANKS, ALASKA, 1900-1930
}

\author{
By \\ John P. Baeten
}

\begin{abstract}
A THESIS
Submitted in partial fulfillment of the requirements for the degree of MASTER OF SCIENCE

(Industrial Archaeology)
\end{abstract}

MICHIGAN TECHNOLOGICAL UNIVERSITY

2012

(c) 2012 John P. Baeten 
This thesis, "The Technology, Mining Methods and Landscapes of a Placer Mining District in Fairbanks, Alaska, 1900-1930," is hereby approved in partial fulfillment of the requirements for the Degree of MASTER OF SCIENCE IN INDUSTRIAL ARCHAEOLOGY.

Department of Social Sciences

Signatures:

Thesis Advisor

Patrick Martin

Department Chair

Patrick Martin

Date 


\section{Acknowledgements}

Parts of this thesis are the result of two summers of field work in the Fairbanks Mining District, Alaska. The fieldwork was part of a joint project undertaken by Michigan Technological University, the University of Alaska at Anchorage and the Bureau of Land Management - Central Yukon Field Office.

This project funded my research and fueled my interest in historic placer mining in Alaska and for this I am grateful.

In Fairbanks thanks to BLM staff archaeologists Bill Hedman and Steve Lanford for sharing their vast knowledge of the Fairbanks region and assisting with logistics along the way. In the field I had the pleasure of working and learning with a number of fellow archaeologists, whom battled through alder, black flies and mosquitoes recording the ever present prospect pits along the way. Special thanks to Paul White, Kelsey Anderson, Tamara Holman, Mark Rollins, Zach Lasiter, Ayla Aymond, Danielle Ellis, Jessica Peterson and Alfonso Tinoco.

At Michigan Technological University, I am indebted to committee chair Patrick Martin who provided helpful critique and encouragement during this process and for including me in the Alaska project. Special thanks to committee member Fredric Quivik for helping me hone my writing and for introducing me to mining landscapes and broader theoretical concepts in IA. Special thanks to committee member Paul White of UAA, who broadened my appreciation for industrial sites and documentation during our time in Fairbanks and for making me a better archaeologist. Tim Goddard and Mike Hyslop provided valuable GIS assitance throughout the project.

Thanks to faculty and staff in the Social Sciences department at Michigan Tech for making my graduate experience a great one! Also, thanks to fellow 
students in the Industrial Archaeology program, who have fostered a truly fun learning experience.

Lastly, thanks to my wonderful wife and fellow archaeologist Tesa, who's keen eye for detail and words of encouragement have helped me along the way. 
Table of Contents

Acknowledgements ...................................................................................

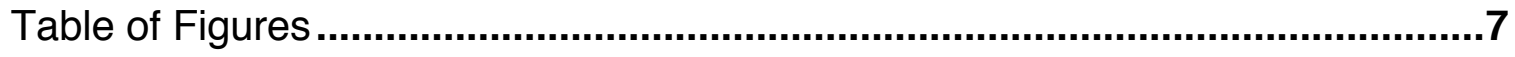

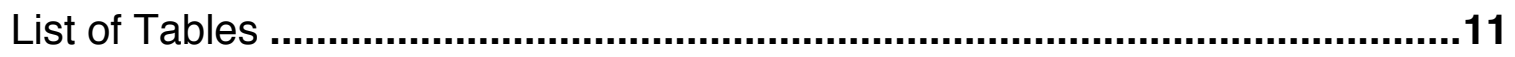

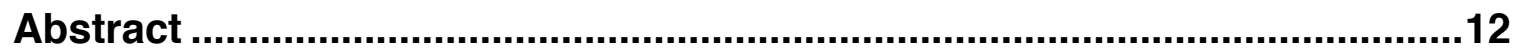

Chapter 1: Research Questions and Methods...........................................13

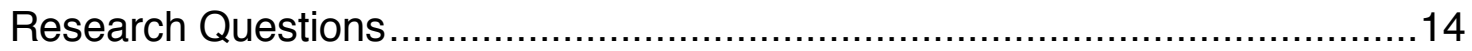

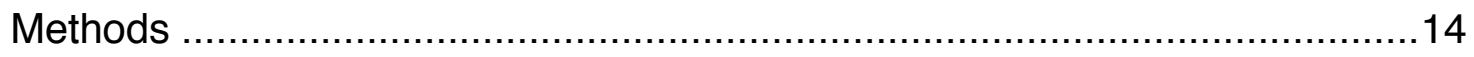

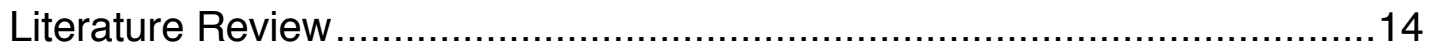

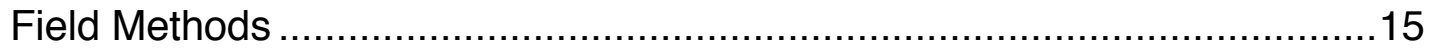

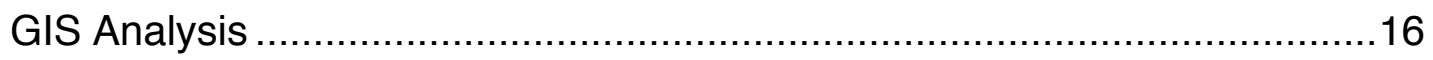

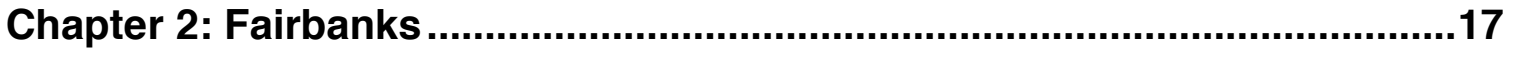

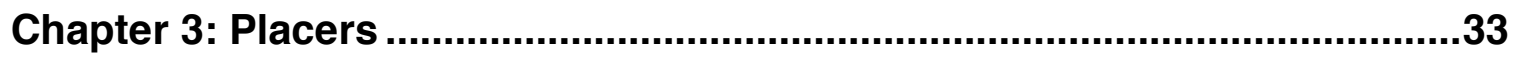

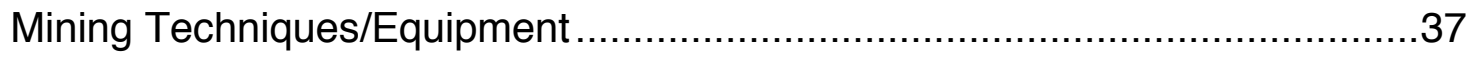

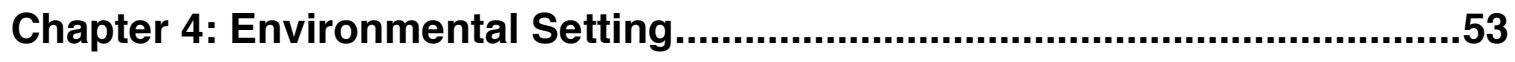

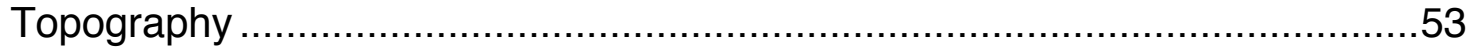

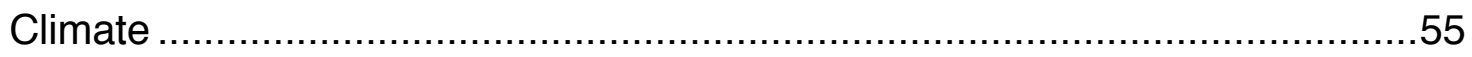

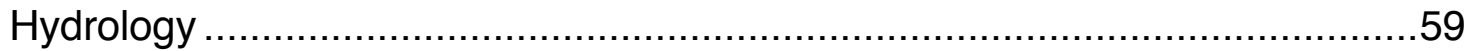

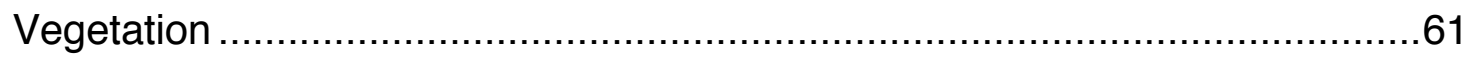

Chapter 5: Mining Methods and Technologies at Fairbanks .......................64

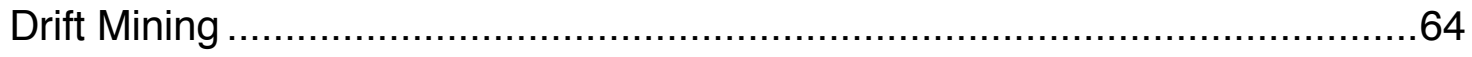

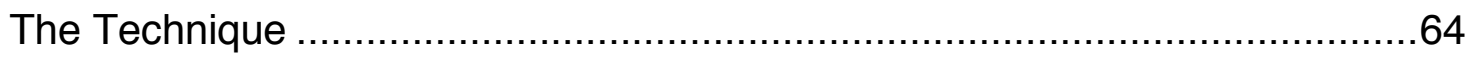

The Process: Prospecting, Development, Sluicing, Winter Mining …..............65

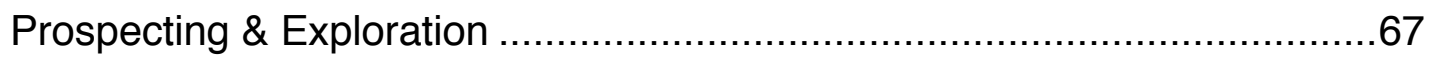

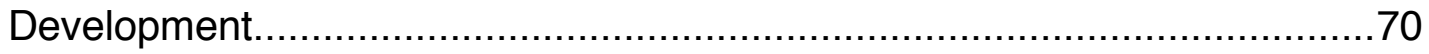


The Equipment: Boilers, Hoists, Self-Dumping Carriers, Headframes, and

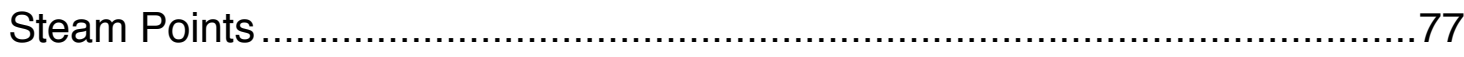

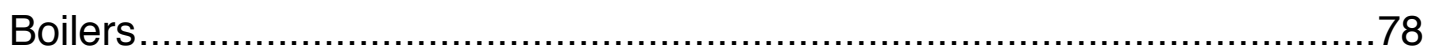

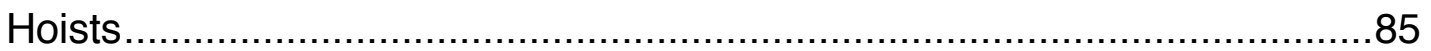

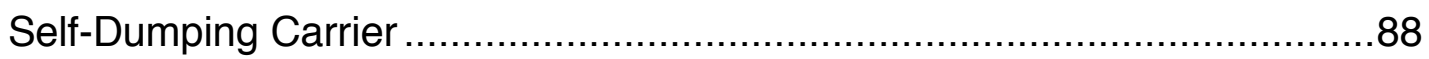

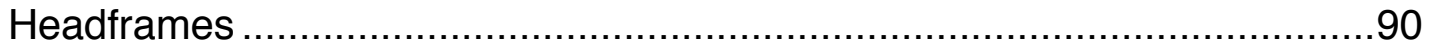

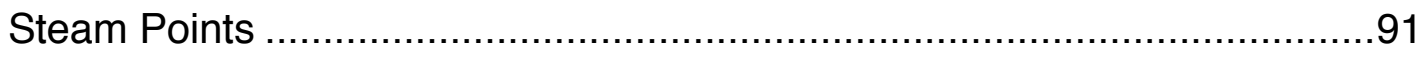

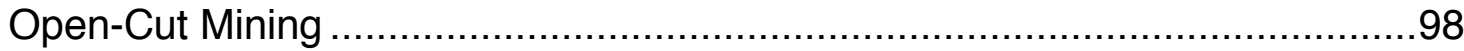

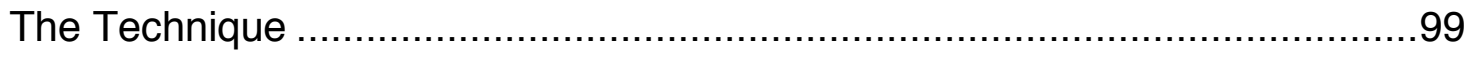

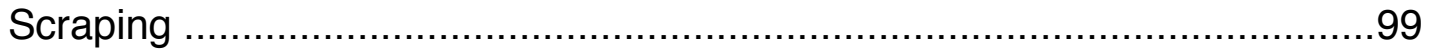

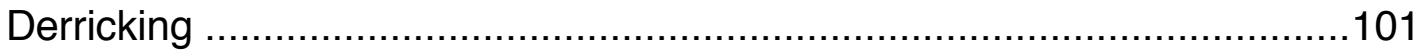

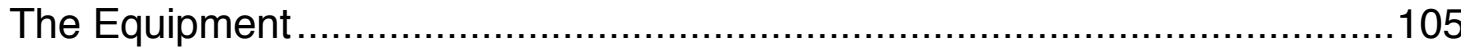

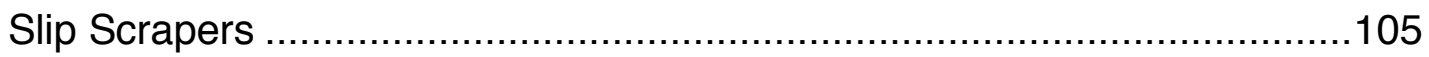

Bagley or Bottomless Scraper .........................................................107

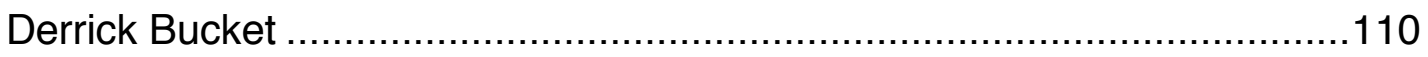

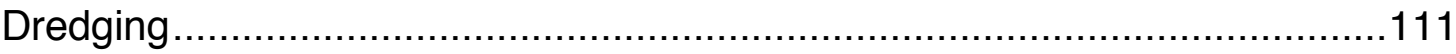

Chapter 6: The Placer Mining Landscape ............................................119

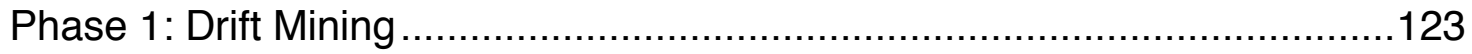

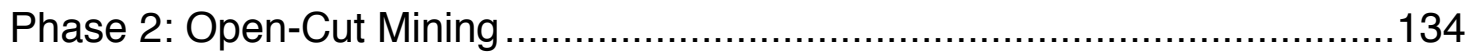

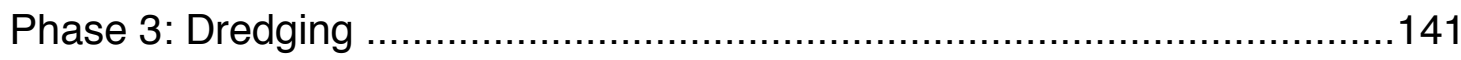

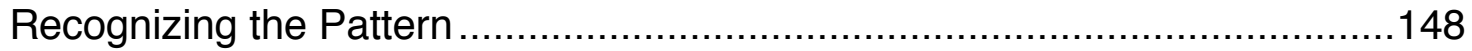

Chapter 7: Summary and Conclusions....................................................149

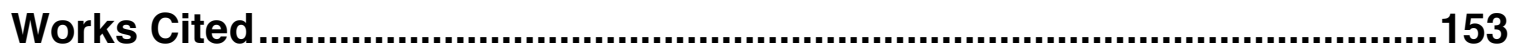




\section{Table of Figures}

Figure 2.1: Location of the Yukon and Tanana Rivers (Baeten: 2012) ..............18

Figure 2.2: Barnette's Trading Post, 1902 (Courtesy of Alaska State Library,

Alaska Purchase Centennial Collection, Accession \#ASL-P20-106) ............20

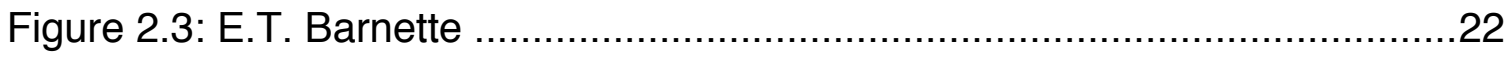

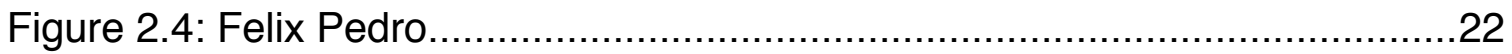

Figure 2.5: Overview of the Fairbanks Mining District (Baeten: 2012) ...............23

Figure 2.6: Fairbanks in 1904 (Courtesy of University of Alaska Fairbanks,

Alaska and Polar Regions Collection, Robert Jones Collection, Accession

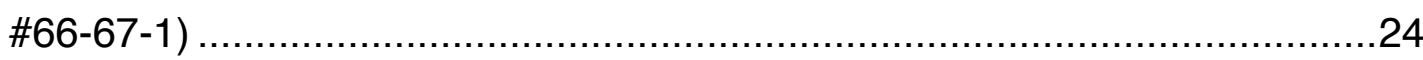

Figure 2.7: Hauling Supplies on the Fairbanks-Valdez Trail (Courtesy of University of Alaska Fairbanks, Alaska and Polar Regions Collection, Albert Johnson Collection, Accession \#UAF-1989-166-544) …............................26

Figure 2.8: Tanana Valley Railroad (Baeten: 2012 - Digitized from Prindle \& Katz, 1913) .27

Figure 2.9: Overview of Settlements Within the Fairbanks Mining District (Baeten: 2012)

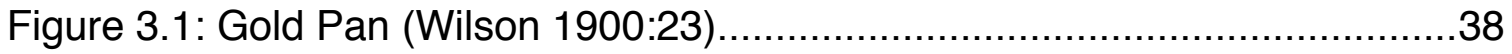

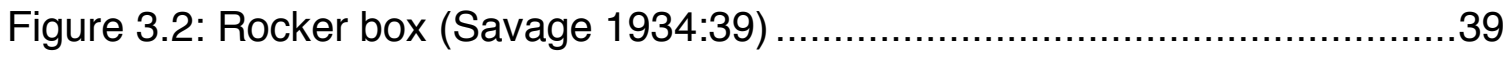

Figure 3.3: Examples of riffles (Jackson 1938:36) .........................................40

Figure 3.4: Long tom (Bowie 1905:204).........................................................

Figure 3.5: Sluicing arrangement (Jackson 1938:40) .....................................42

Figure 3.6: Typical sluice box (LaLande 1985:32) ........................................43

Figure 3.7: Profile of undercurrent (Bowie 1905: Figure 68) ............................44

Figure 3.8: Undercurrent arrangement (Wilson 1900:36) .................................45

Figure 3.9: Sluice with cobblestone riffles in Alaska (Purington 1905:Plate XXIV)

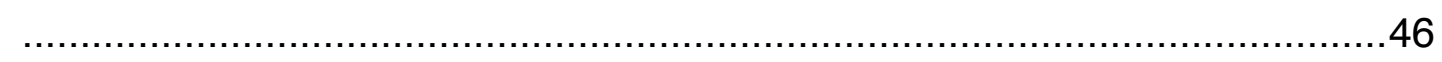

Figure 3.10: Boomer dam (Purington 1905:Plate V) .......................................47 
Figure 3.11: Hydraulic Monitor (Bowie 1905:183) ........................................49

Figure 3.12: Hydraulic pipe segments (Purington 1905:131)...........................50

Figure 3.13: Profile of dredge (Courtesy Library of Congress, Historic American

Engineering Record, AK, 19-EGL.V,4A) ..................................................

Figure 3.14: Cast iron dredge buckets (Purington 1905:Plate XXXII) ................51

Figure 4.1: Map showing the location of the Yukon-Tanana Uplands (Baeten:

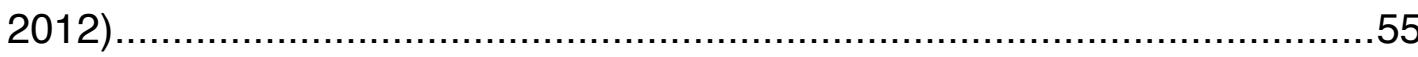

Figure 4.2: Distribution of Permafrost in the Fairbanks Region (Baeten: 2012) ..57

Figure 4.3: Road Construction Technique in the Klondike (Purington, 1905:225)

Figure 4.4: Overview of Ditches in the Fairbanks District (Baeten: 2012 - Digitized Map by Prindle, Katz \& Hill, 1933) .......................................................6

Figure 4.5: Distribution of Timber in the Fairbanks District in 1908 (Baeten: 2012 Digitized Map by Prindle \& Katz, 1908) .................................................62

Figure 5.1: Winter dump in the Fairbanks district (Courtesy of University of Alaska Fairbanks, Alaska and Polar Regions Collection, Albert Johnson Collection, Accession \#UAF-1989-166-634)................................................66

Figure 5.2: Thawing a prospect pit (Ellis 1915:10) .........................................69

Figure 5.3: Square set cribbing (Ellis 1915:19) .............................................

Figure 5.4: Cross section of drift mine, note sluice within dump (Wimmler

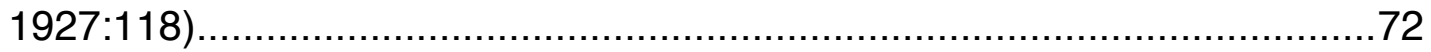

Figure 5.5: Plan view of drift mine (Wimmler 1927:119) .................................74

Figure 5.6: Underground drift mining in Fairbanks (Courtesy of University of Alaska Fairbanks, Alaska and Polar Regions Collection, Albert Johnson Collection, Accession \#UAF-1989-166-30)................................................76

Figure 5.7: Porcupine boiler (Goddard 2010) ................................................

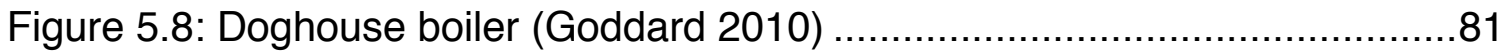

Figure 5.9: Locomotive Boiler (International Library of Technology 1924:13) .....83 
Figure 5.10: Hand windlass above shaft (Courtesy of University of Washington Libraries, Special Collections, William E. Meed Collection, UW16633)........86

Figure 5.11: Diagram of carrier (Ellis 1915:14) ............................................8

Figure 5.12: Operation of carrier while dumping (Ellis 1915:15) .......................90

Figure 5.13: Typical Fairbanks Headframe (Ellis 1915:18)..............................91

Figure 5.14: Steam point (Purington 1905:90) ............................................93

Figure 5.15: Sweaters in the drift (Courtesy of University of Alaska Fairbanks, Alaska and Polar Regions Collection, Albert Johnson Collection, Accession

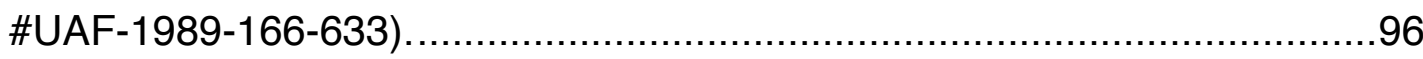

Figure 5.16: Example of steam pipe manifold (Ellis 1915:24). ........................97

Figure 5.17: Plan of scraper operation (Wimmler 1927:97) ............................101

Figure 5.18: Overview of Derricking plant, note tailings derrick (Purington

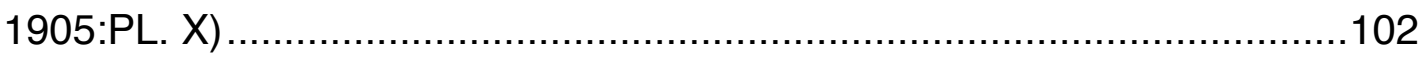

Figure 5.19: Elevation of derrick plant showing pulley system (Purington 1905:

PL. X). 103

Figure 5.20: Miner emptying derrick bucket into sluice next to dump box

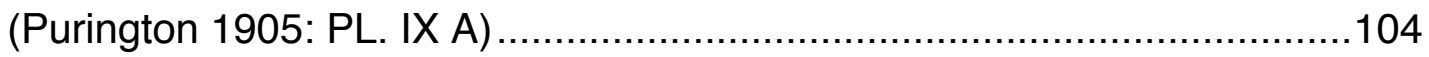

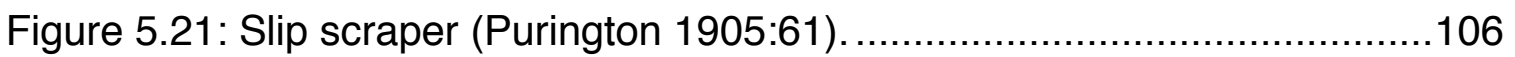

Figure 5.22: Bottomless Scraper, note rear apron and tackle arrangement

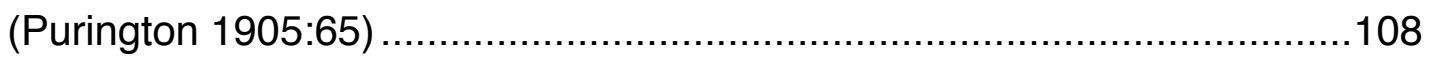

Figure 5.23: Elevation of scraper operation with car in station (Wimmler

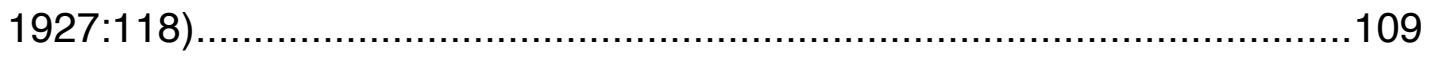

Figure 5.24: Derrick bucket with catch (Purington 1905: PL. XIII B) .................110

Figure 6.1: Overview of Claims in the Fairbanks District. ...............................121

Figure 6.2: Landscape features recorded in 2011, note the abundance of prospecting features and ditches.

Figure 6.3: Modern open-cut landscape in foreground with historic workings in background marked by linear vegetation patterns. (Baeten: 2011) ............123 
Figure 6.4: Washing a winter dump (Courtesy of University of Alaska Fairbanks, Alaska and Polar Regions Collection, Albert Johnson Collection, Accession \#UAF-1989-166-22). 126

Figure 6.5: Cribbed shaft and ladder (Lassiter: 2011) ..................................127

Figure 6.6: Chatham Creek Drift Mine Site (Baeten: 2012) ...........................128

Figure 6.7: Chatham Creek Site Engine House (Baeten: 2011) .....................129

Figure 6.8: Cribbed Shaft (Baeten: 2011) .................................................130

Figure 6.9: Collapsed Gin pole (Baeten: 2011) ........................................132

Figure 6.10: Modified fuel drum bailer (Baeten: 2011) ..................................133

Figure 6.11: Slip scraper bucket at Cleary Creek (Anderson: 2012) ................135

Figure 6.12: Overburden piles (Baeten: 2011) ............................................136

Figure 6.13: Kokomo Creek Open-cut Site (Baeten: 2012) ….........................137

Figure 6.14: Crew members stand on the conveyance route of the scraper in the Eastern Foci (Peterson: 2011) .......................................................139

Figure 6.15: Steam powered winching engine (Baeten: 2011) .......................140

Figure 6.16: Typical Dredge Landscape in Ester (Boswell, 1979:85) ...............142

Figure 6.17: Thawed and prepared dredging area, showing intact cribbed shaft from prior drifting (Courtesy Anchorage Museum of History \& Art, Ickes Collection, Accession \#B75-175-259).................................................143

Figure 6.18: Dredged landscape at Fairbanks Creek (Tinoco 2012) ...............144

Figure 6.19: Gilmore Creek Dredging Site (Baeten:2012) …........................145

Figure 6.20: Linear dredge tailings (Peterson: 2011)..................................146

Figure 6.21: Damaged trommel screens (Baeten: 2011) ...............................147

Figure 7.1: Total placer output from 1903-1929 (Digitized from Hill, 1933) .......151

Figure 7.2: Chart shows the eventual shift from drift mining to open-cut mining and dredging (Digitized from USGS Bulletins and Alaska Annual Reports) 


\section{List of Tables}

Table 6.1: Equipment used in the Fairbanks placer mines .......................... 128 
"It was the river that fashioned the land, and the river that ground down the gold."

Klondike Fever, Pierre Berton 1958

\section{Abstract}

Placer miners in Alaska's interior were part of the last great gold rush in North America. As word of gold in the Fairbanks Mining District traveled down the Yukon River, a wave of miners from the Klondike placer fields in Dawson, along with a assortment of speculators and inexperienced green horns from the Lower 48 converged on the confluence of the Tanana and Chena rivers hoping to strike it rich. The steamers coming from Dawson were integral; they carried miners with experience working the frozen subarctic placer deposits of the Klondike. These miners encountered new environmental challenges that required the development of new technologies and mining methods to efficiently harvest gold. These methods and machines were brought into Fairbanks and further perfected to account for the local conditions. This thesis describes the local mining technologies and methods employed in the Fairbanks district and the landscape patterns created during the placer mining boom years of 1903-1909, decline years of 1910-1923 and recovery of 1923-1930. 


\section{Chapter 1: Research Questions and Methods}

Starting in the summer of 2010, archaeologists from Michigan Technological University (MTU) and the University of Alaska Anchorage (UAA) have worked together on a joint project with the Bureau of Land Management (BLM) in Fairbanks, Alaska. A central focus of the project is conducting archaeological surveys within historic mining claims in lands managed by the Central Yukon Field Office of the BLM. The purpose of these surveys is twofold; the primary aim is identifying potential hazards, or Abandoned Mine Lands (AMLs) features created during past mining activity, while additionally inventorying cultural features within the historic mining claims.

During the summers of 2011 and 2012 field crews spent a total of 14 weeks in the Fairbanks District conducting intensive archaeological investigations in the historic mining claims. This work has produced quantifiable data that provides information detailing the material culture and the landscape features left behind from past mining activity. These inventories generate meaningful numbers for the BLM, with a focus on the physical description and location of the features. These inventories can also be used to answer many questions beyond the AML questions, among them questions such as: who created the mining feature and when was the feature created, why was the mining feature created and how was the feature constructed, and what technology or mining method was responsible for the feature's construction? These questions led to broader research objectives, such as how can archaeological field data be used to give us a better understanding of the cultural landscape of an historic mining district? This objective is addressed in the following research questions. 


\section{Research Questions}

What mining methods and technologies helped make Fairbanks the preeminent producer of placer gold in Alaska?

What, if any, distinctive mining trends or patterns occurred in the Fairbanks district? What impact, if any, did these trends have on the region? How do these impacts compare to each other?

Are the historic mining methods still evident on the cultural landscape? How does the cultural landscape in Fairbanks compare to the mining landscape in other mining districts in Alaska? Are the mining methods and surface arrangements described in secondary source material visible in the cultural landscape?

\section{Methods}

My methods for this thesis entailed literature reviews, field survey and Geographical Information Systems (GIS) analysis. My objective was to review historic literature and apply this knowledge to field surveys, hoping to be able to identify mining methods and technologies by the surface layout and character of the mining landscape. Features located in the field often appear random, but by analyzing these data in a GIS, patterns become apparent and assist in the identification of a mining landscape.

\section{Literature Review}

The majority of the literature I reviewed consisted of government documents, both federal and state, along with period mining manuals. Bulletins published by the United States Geological Survey (USGS) from 1903-1930 proved to be extremely helpful in identifying historic mining locations, as well as defining the method of mining occurring at the mines. Purington's 1905 bulletin, Gravel and Placer Mining in Alaska, and Wimmler's 1927 bulletin, Placer-Mining Methods and Costs in Alaska, provided detailed accounts of mining methods and 
costs in the Fairbanks region. Annual reports, Report of the Mine Inspector for the Territory of Alaska, published from 1913-1930 provided quantitative data regarding numbers of mines operating in the Fairbanks district and the mining method employed. Peele, Lewis and Young, in their handbooks published for mining engineers and students, describe the contemporary technologies used in the Fairbanks mines. Their descriptions of the historic equipment and technological processes lent to my understanding of the surface features seen in both the open-cut and drift mining landscapes features and artifacts.

In addition to the government publications and mining handbooks, period dissertations and theses provided helpful insight into early Fairbanks placer mining. Parker's thesis, The Evolution of Placer Mining Methods in Alaska, Robe's dissertation, The Penetration of an Alaskan Frontier: The Tanana Valley and Fairbanks and especially Ellis's thesis, Mining Methods at Fairbanks, describe in detail early mining methods, local technologies and circulation within the Fairbanks Mining District. Ellis expands his thesis coverage of Fairbanks in articles published in The Engineering and Mining Journal, describing in greater detail drift mining in the winter, thawing equipment and mine development.

Comparable studies of other mining districts in Alaska were found in: Mary Barry's A History of Mining on the Kenai Peninsula, Paul White's Cultural Landscape Report of the Bremner Historic District, Carol Feldman's ChisanaGold Hill Landscape and Becky Saleeby's CRMIM: The Quest for Gold. These reports explained mining trends prevalent in placer mining districts and were useful in my designation of the phases of mining seen in the Fairbanks region.

\section{Field Methods}

Staff archaeologists at the BLM identified priority areas to investigate during our archaeological survey. These priority areas were those most likely to be subject to active mining in the near future, making the inventory of cultural features a focus for the BLM. Prior to conducting pedestrian surveys through 
these areas, we consulted historic USGS Bulletins that helped us identify what types of cultural features we might find. In addition to searching historic documents, we also examined aerial imagery, looking for signs of human activity in abandoned machinery, structures or surface work. Areas appearing to contain cultural features were then subject to higher intensity surveys.

\section{GIS Analysis}

After field data is collected on a Geographical Positioning System (GPS) this information is entered into a GIS. The GIS helps show patterns that were ambiguous in the field; in the field ditches may appear as unconnected routes, but within a GIS their articulation on the landscape becomes apparent. In addition to the field data entered into the GIS, I also georeferenced historic maps from USGS bulletins that helped with my creation of some of the maps seen in this thesis. 
"With the aid of field glasses the name on her pilot house, Lavelle Young, was readable" The Evolution of Placer Mining Techniques in Alaska, Genevieve Parker 1929

\section{Chapter 2: Fairbanks}

This chapter describes the geographical location, founding and development of the Fairbanks region, with special attention placed on the natural and cultural elements influential in the settling of Fairbanks and how they led to its success as the most profitable placer-mining district in Alaska. This chapter provides an historical context for early twentieth century subarctic placer mining, examining the methods, costs and transportation systems used in the Fairbanks Mining District from 1902-1910.

The Yukon River originates in the Pelly Mountains of the Yukon Territory. From there, its course runs across Alaska for nearly 2,000 miles, terminating at the Bering Sea. It flows generally west across the Yukon Territory and bisects Alaska. Thousands of years ago the Athabascans settled along its banks. The Athabascans used the Yukon River as a gateway into the interior of present-day Alaska, trading and pursuing food sources.

The 1896 gold rush into the Yukon Territory created an influx of EuroAmericans entering the far north, settling along the Yukon River, primarily at Dawson. These later arrivals were searching for fortune, and the Yukon River, "the great artery of the north" (Berton 1959), acted as a major transportation route for prospectors traveling from the Klondike and into interior Alaska. ${ }^{1}$ From Dawson and St. Michael prospectors boarded steamers and sternwheelers, and set off to explore the virgin stream gravels of Alaska's interior. ${ }^{2}$

\footnotetext{
${ }^{1}$ Pierre Berton, The Klondike Fever (New York: Alfred A. Knopf, 1959) 437.

${ }^{2}$ St. Michael is a small port town located just south of Nome, Alaska. St. Michael was used as a staging area for prospectors arriving by ship from Seattle at the turn of the century. From here prospectors rented steamers and traveled up the Yukon River.
} 
Nearly 600 miles east of St. Michael the Yukon River forms a confluence with its major tributary, the Tanana River (see Figure 2.1). The Tanana River originates in eastern Alaska, it flows northwest for nearly 600 miles until it enters the Yukon River. The first American expedition up the Tanana River occurred in 1885, when Lieutenant Henry Allen and four others, searched for an-all water passage through Alaska. ${ }^{3}$

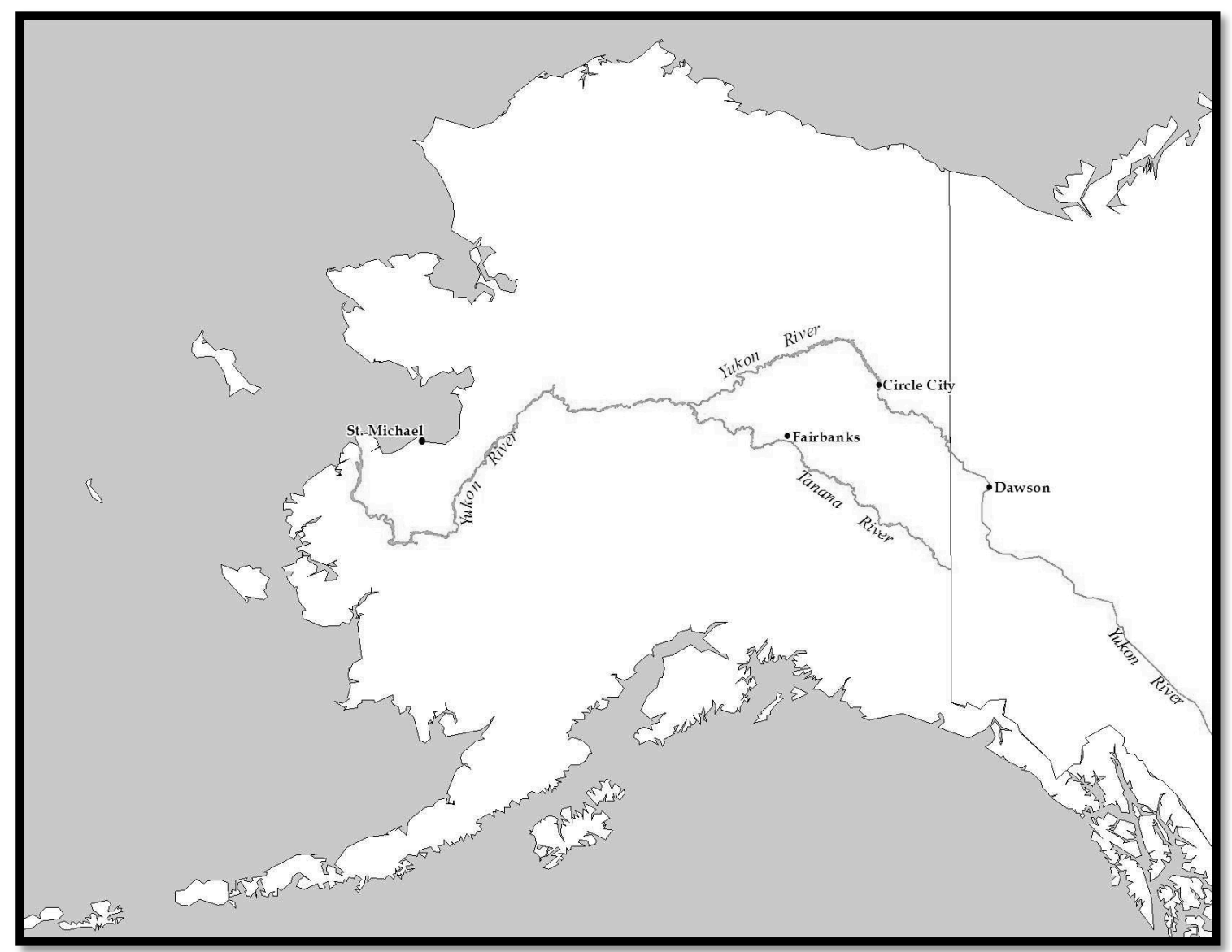

Figure 2.1: Location of the Yukon and Tanana Rivers (Baeten: 2012)

\footnotetext{
${ }^{3}$ Alfred Brooks, Blazing Alaska's Trails (Washington: University of Alaska and the Arctic Institute of North America, 1953) 276-277.
} 
The Tanana is a wide, heavily braided river that at times appears more like a swamp than a body of running water. ${ }^{4}$ A notably shallow spot is located approximately 170 miles from its confluence with the Yukon, where the Chena River flows into the Tanana. Fairbanks is located along the south bank of the Chena River, about 3 miles east of its confluence with the Tanana. The settling of Fairbanks was due to the shallowness of the Tanana and Chena Rivers, the determination of a few prospectors and the miscalculations by the earliest speculator in the Tanana Valley, E.T. Barnette.

In 1901, the steamer Lavelle Young, carrying Barnette, traveled east from St. Michael aiming to set up a trading post on the banks of the Tanana River. ${ }^{5}$ Barnette was familiar with the area; he previously attempted to take a steamer from St. Michael to the Dawson gold fields in 1897, but only made it as far as Circle City. At Circle City, his reputation soured with the local miners when he created a monopoly on the local flour market during a food shortage. ${ }^{6}$ Barnette leased the Lavelle Young, and filled her with 100 tons of provisions intended to supply a potential railroad camp near present day Delta Junction. The Lavelle Young ran aground nearly 300 miles west of her destination on a shallow bank near the confluence of the Chena and Tanana. ${ }^{7}$ At this point Barnette had the

\footnotetext{
${ }^{4}$ Terrence Cole, Crooked Past: The History of a Frontier Mining Camp: Fairbanks, Alaska (Fairbanks: University of Alaska Press, 1984) 20.

${ }^{5}$ Genevieve Parker, The Evolution of Placer Mining Methods in Alaska (Fairbanks: Unpublished Thesis, 1929) 10.

${ }^{6}$ William R. Hunt, North of 53', The Wild Days of the Alaska-Yukon Mining Frontier 1870-1914 (New York: MacMillen Publishing Co. Inc, 1974) 166-167. Barnette, mayor, convict-banker, and "rogue of the river", has a well-documented, at times nefarious past. For in depth accounts of Barnette, see the above mentioned 166-175, Terrance Cole's Crooked Past and the University of Alaska Anchorage's Digital Archives, E.T. Barnette: Fortune Seeker, Fortune Taker 1860-1930. ${ }^{7}$ T.A. Rickard, Through the Yukon and Alaska (San Francisco: Mining and Scientific Press, 1909) 263.
} 
boat push north up the Chena but was grounded again. Unable to press further, The Lavelle Young dropped anchor near an elevated, densely forested area, and Barnette's supplies were unloaded (see Figure 2.2). ${ }^{8}$

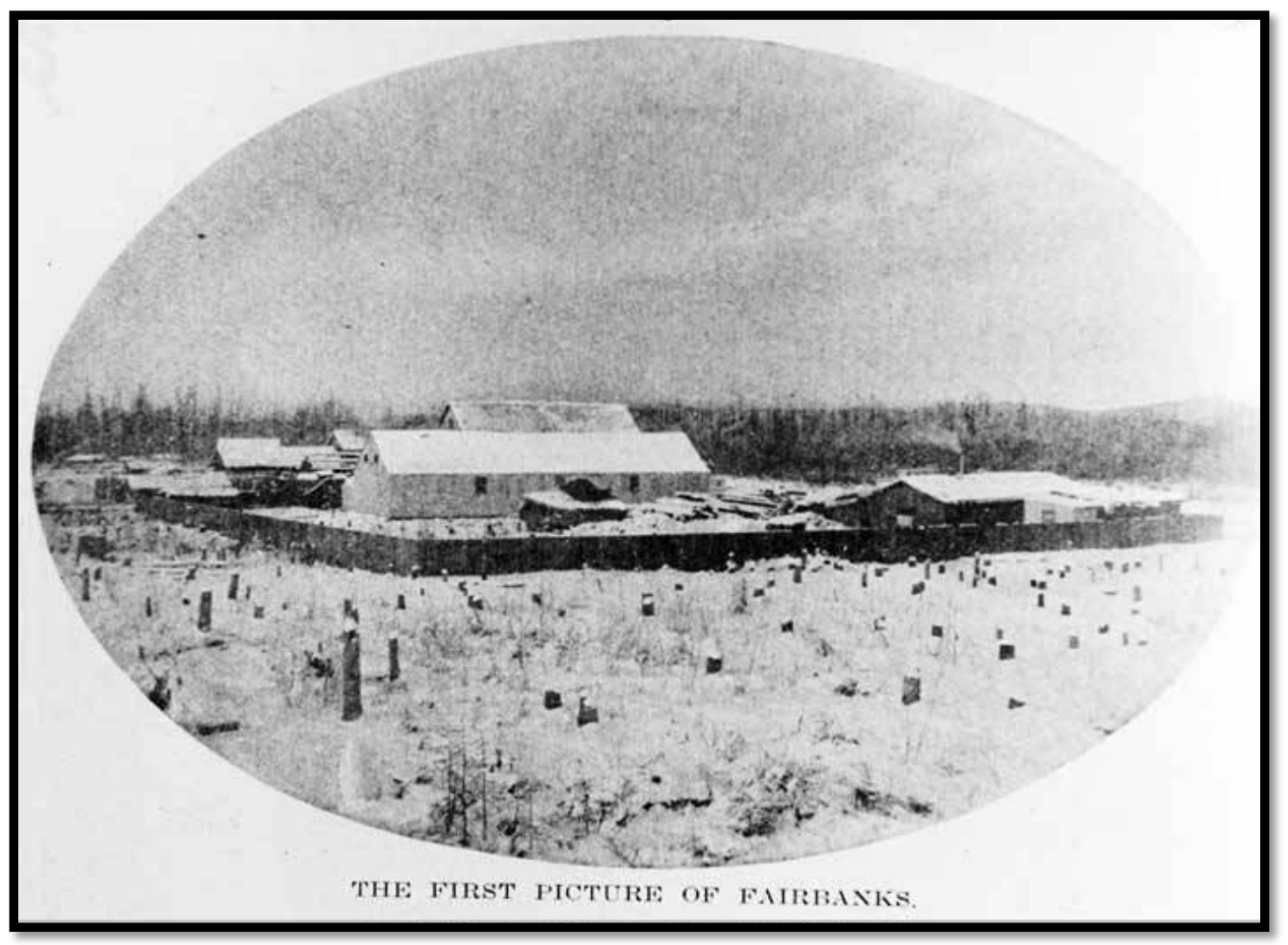

Figure 2.2: Barnette's Trading Post, 1902 (Courtesy of Alaska State Library, Alaska Purchase Centennial Collection, Accession \#ASL-P20-106)

As the ship was steaming up the Chena, a group of prospectors were reaching the apex of a hill, later known as Pedro Dome, to survey the surrounding country. The prospectors, nearly out of supplies, spotted the Lavelle Young through field glasses and made the roughly fifteen mile trek to where she was docked. ${ }^{9}$ Upon arrival, the prospectors, Felice Pedroni and Tom Gilmore,

${ }^{8}$ T.A. Rickard, Through the Yukon and Alaska, 262.

9 James C. Hildebrandt, History of Placer Mining in Alaska (Fairbanks: Unpublished Thesis, 1917) 33. 
purchased supplies from Barnette and informed him of the potential value in the local placer deposits (see Figure 2.3, 2.4). Seeing that active prospecting was occurring in the area, Barnette choose to erect a trading post, gambling on the future success of the area. ${ }^{10}$ The preemptive grounding of the Lavelle Young turned out to be a serendipitous event for Barnette, as "Felix Pedro" (Pedroni) discovered gold near the trading post in 1902. ${ }^{11}$ As word of gold in the Tanana Valley spread to Circle and Dawson, the small trading post on the Chena spawned a larger development.

The winter of 1903 saw hundreds of men making the overland dogsled journey from Circle and Dawson, with the main rush ensuing that summer. By the summer of 1903 the population of Fairbanks was 800 and by 1904 it reached 3,000 . The expectations of the initial stampeders to Fairbanks were exaggerated, as Barnette spread word to Dawson that the creeks were ripe with gold. Instead, prospectors found a ramshackle town, lacking the amenities of Dawson, with nearly all of the claims around Pedro's discovery staked out (see Figure 2.5). At this time, claims in Alaska could be staked through a power of attorney. Speculators exploited this clause by staking claims for friends and relatives thousands of miles away. The speculators themselves had little interest in exploring and leased the claims out to actual miners. The men working the claims, would in-turn, pay the speculators up to $50 \%$ of the total output from the mine. Also lacking was modern high-capacity mining equipment; the deep frozen placers were worked by pick, pan, portable boilers and wood-fires, discouraging many of the stampeders to the point of retreat.

\footnotetext{
${ }^{10}$ Hunt, North of $53^{\circ}, 137$.

${ }^{11}$ Hunt, North of $53^{\circ}, 137$. For a complete history on Felix Pedro and the original prospectors in the Fairbanks region see Genevieve Parker's, The Evolution of Placer Mining Methods in Alaska (7-15) and Terrence Cole's, Crooked Past (13-44).
} 


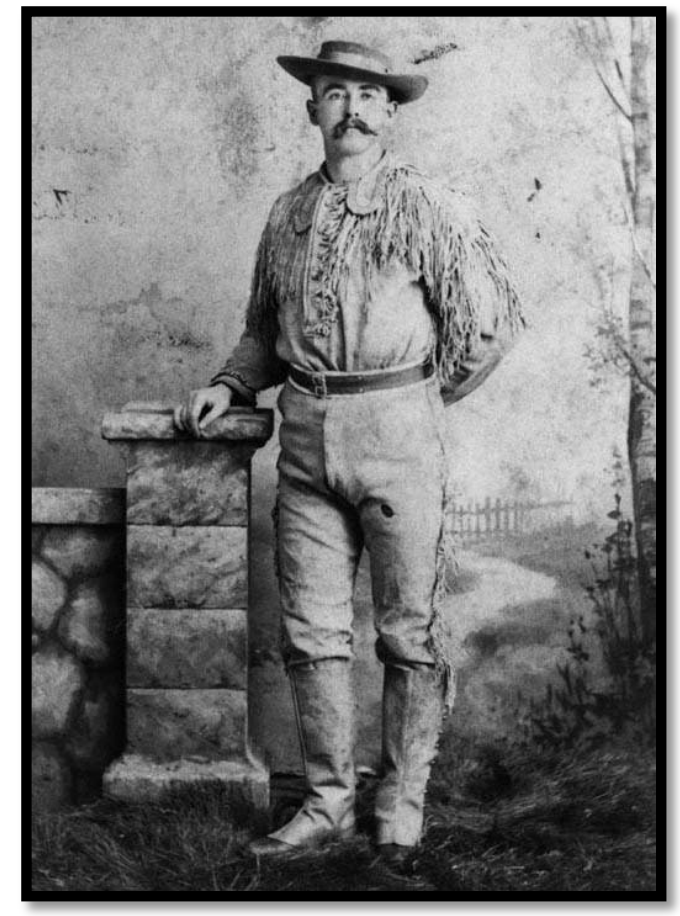

Figure 2.3: E.T. Barnette

(Courtesy of University of Alaska Fairbanks, Alaska and Polar Regions Collection, Accession \#UAF-1989-12-102)

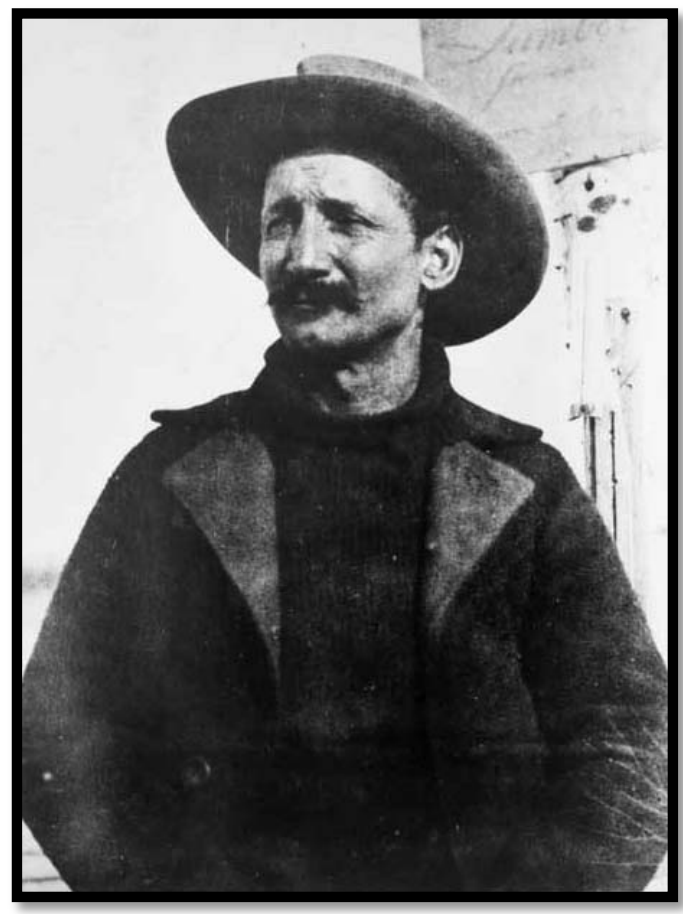

Figure 2.4: Felix Pedro

(Courtesy of University of Alaska Fairbanks, Alaska and Polar Regions Collection, Accession \#UAF-65-2)

Most of the prospectors arriving from Dawson had experience working frozen placers from their time in the Klondike. The Klondike miners were versed in the use of boilers as thawing agents that emitted hot water and steam that was sent through hoses to attached steam points (described later). Boilers acted as the main energy converters, creating steam that efficiently thawed the frozen alluvium. Boilers generated a constant supply of regulated heat and with the steam points the miners effectively directed the heat downward into the shaft. 


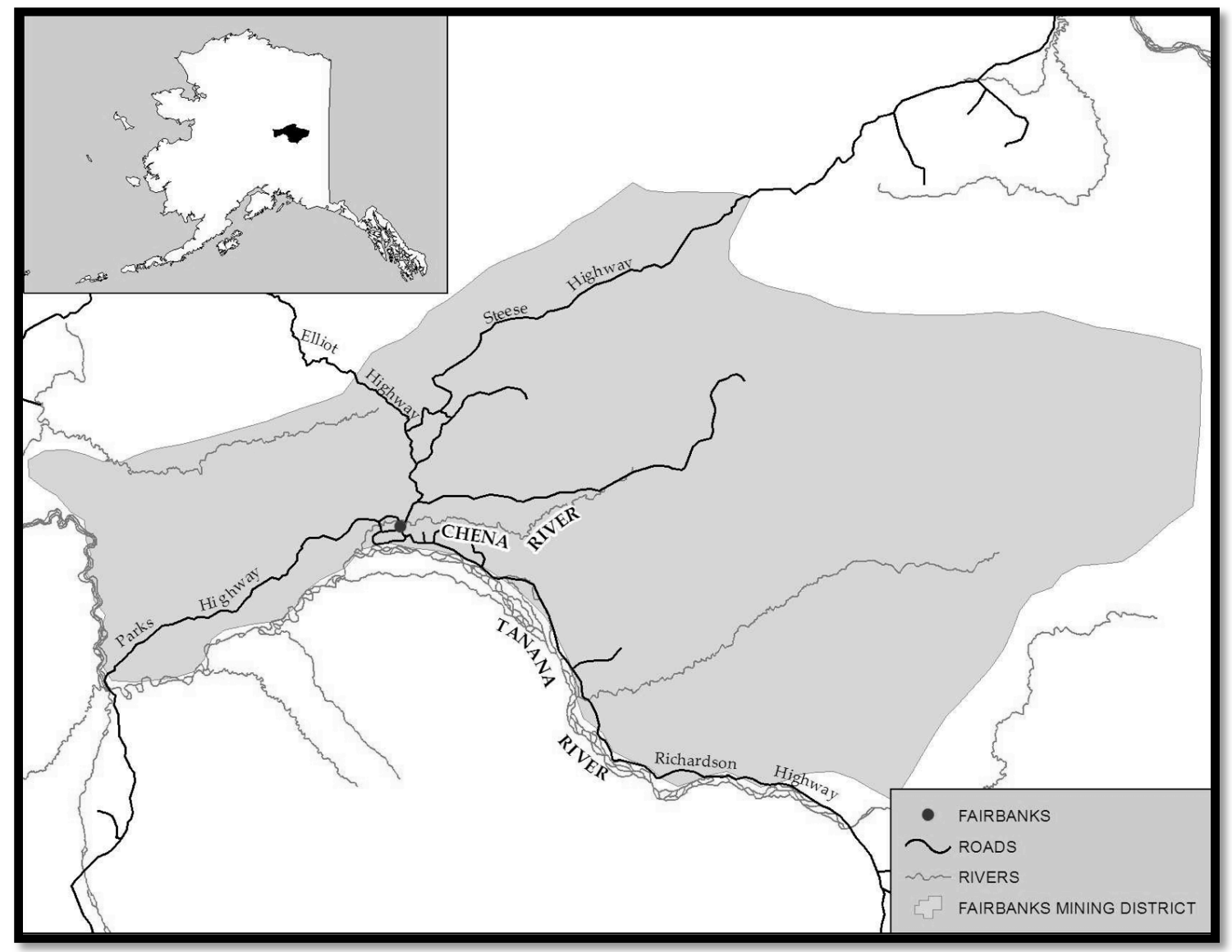

Figure 2.5: Overview of the Fairbanks Mining District (Baeten: 2012)

Early prospectors lacked portable boilers, and in turn, had built wood fires directly on top of the frozen deposit they planned to extract. Although the wood fires were successful at thawing the deposit, they tended to thaw both vertically and horizontally, creating an amorphous pit that was expensive to extract and also prone to subsidence. ${ }^{1}$ With a crew of two men, the wood-fire thawing technique allowed for the successful extraction of about one foot of frozen gravel per day. ${ }^{2}$ In comparison, two men using a boiler with steam points could thaw

\footnotetext{
${ }^{1}$ Parker, The Evolution of Placer Mining Methods in Alaska, 22.

${ }^{2}$ Hildebrandt, History of Placer Mining in Alaska, 36.
} 
about five times as much alluvium per day. ${ }^{3}$ The initial prospecting boilers brought into the Fairbanks district had a low capacity and were portable. As more miners entered the region, they brought with them new technologies and larger machines. By the spring of 1904, larger, high-capacity boilers and hoists were installed on many of the claims, replacing the manual technologies. ${ }^{4}$ The introduction of these improved technologies and intense prospecting increased the production and profits of the district, resulting in increasing development of the Fairbanks region (see Figure 2.6). By 1903, government offices and three sawmills were constructed in Fairbanks, and a telephone system connected the mines to Fairbanks, while telegraph connected Fairbanks to Seattle. ${ }^{5}$

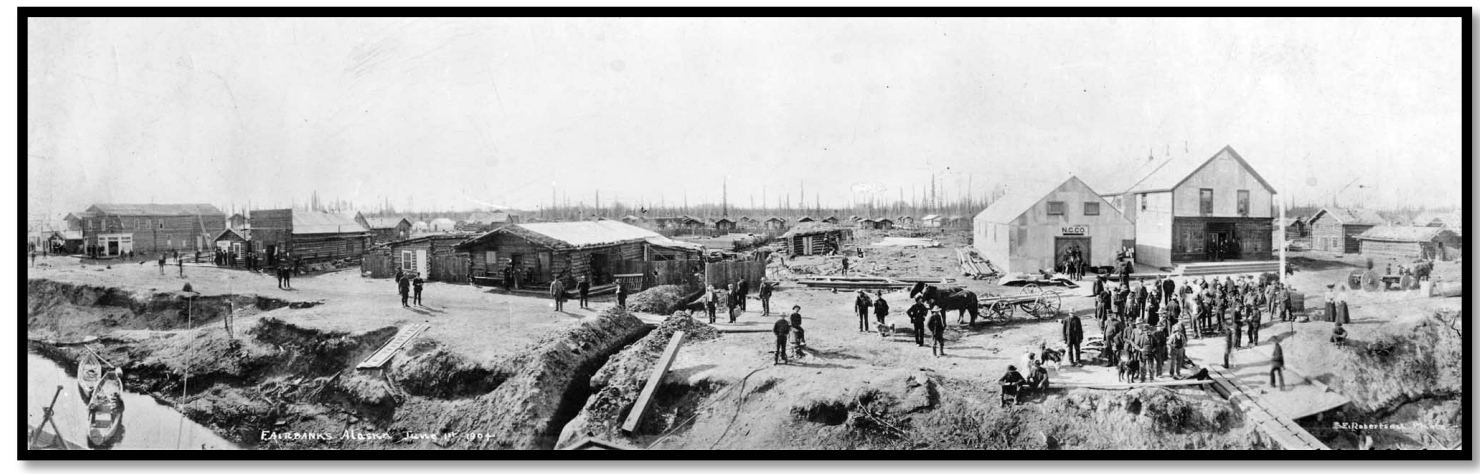

Figure 2.6: Fairbanks in 1904 (Courtesy of University of Alaska Fairbanks, Alaska and Polar Regions Collection, Robert Jones Collection, Accession \#66-67-1)

\footnotetext{
${ }^{3}$ Chester Wells Purington, "Methods and Costs of Gravel and Placer Mining in Alaska", USGS Bulletin No. 263 (Washington: GPO, 1905) 84-85.

${ }^{4}$ Hildebrandt, History of Placer Mining in Alaska, 38. Boilers and hoists were most likely brought in the previous fall before final freeze up of the creeks and assembled during the winter down time.

${ }^{5}$ L.M. Prindle, "Gold Placers of the Fairbanks Mining District, Alaska", Contributions to Economic Geology, USGS Bulletin No. 225 (Washington: GPO, 1903) 66.
} 
The Fairbanks mines were proving to be profitable, but their production was hampered by an expensive and limited system of transportation. The transportation systems within the Fairbanks region were limited to boat or pack trail. Pack trails were used efficiently during the winter months with teams of dogs or horse-drawn sleighs towing supplies from Fairbanks to the mines. During the summer months pack trails were overtaken with thick muck, making travel slow and expensive, especially with heavy loads. The summer saw steamers and sternwheelers on the Chena and Tanana bringing in goods from the outside. By 1904, miners, businessmen and government geologists began advocating for the construction and maintenance of roads within the Tanana Valley. The same year the newly enacted Alaska Road Commission appropriated funds to create a 365-mile addition to the Valdez-Eagle Trail, running to Fairbanks. ${ }^{6}$ The Fairbanks-Valdez trail was originally used as a winter route since it suffered from the same poor summer conditions as other pack trails (see Figure 2.7). By 1909, the Fairbanks-Valdez trail was significantly improved converting much of the pack trail into a wagon road. In 1910, 3,500 people and 2,400 tons of freight traveled overland on the trail. ${ }^{7}$

\footnotetext{
${ }^{6}$ Janet Matheson and F. Bruce Haldemen, "Historic Resources in the Fairbanks North Star Borough", A Report of the Fairbanks North Star Borough Planning Department (Fairbanks: The Borough, 1981) 22.

${ }^{7}$ Matheson and Haldeman, Historic Resources in the Fairbanks North Star Borough, 23.
} 


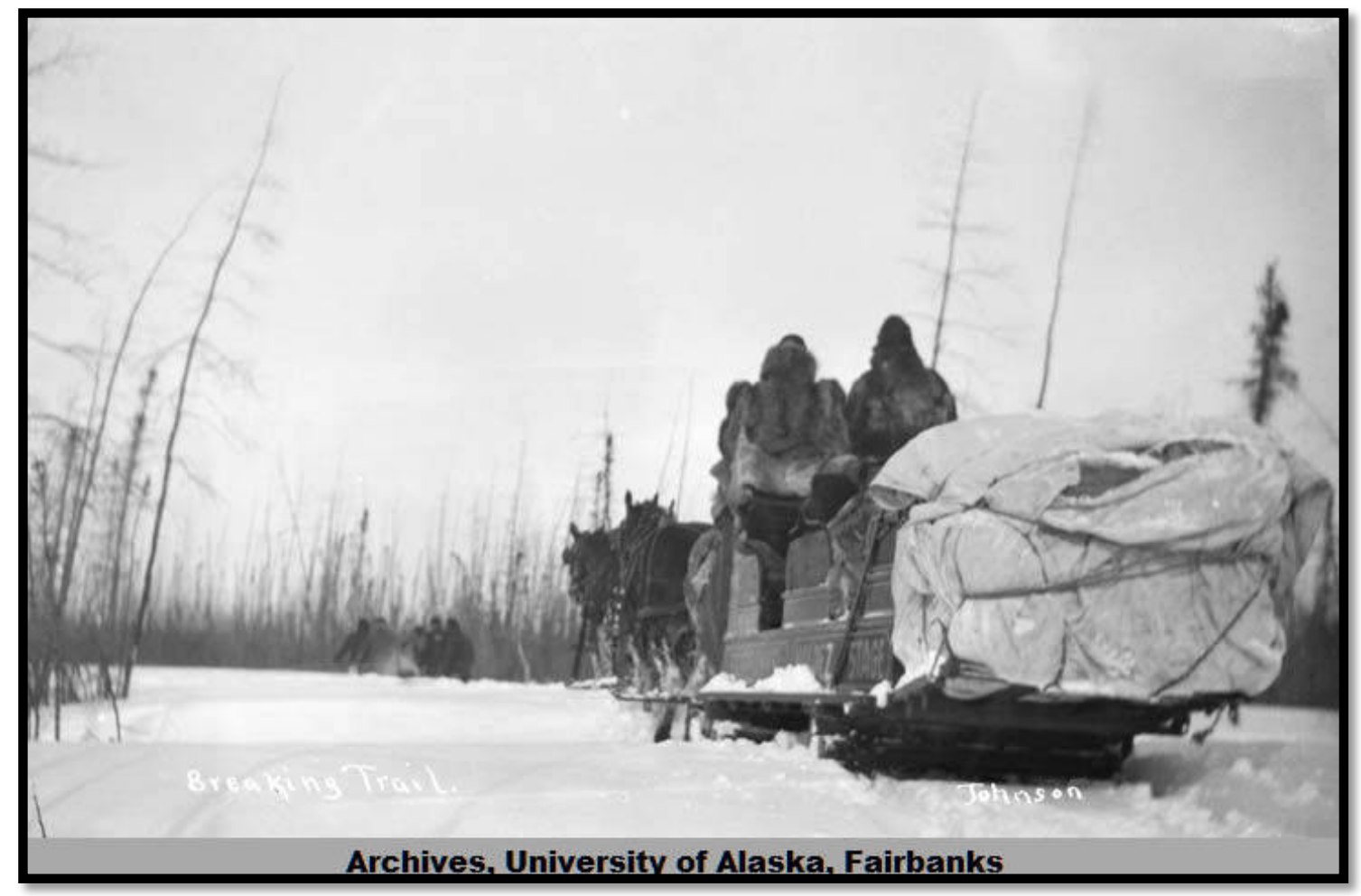

Figure 2.7: Hauling Supplies on the Fairbanks-Valder. Trail (Courtesy of University of Alaska Fairbanks, Alaska and Polar Regions Collection, Albert Johnson Collection, Accession \#UAF-1989166-544)

In1905, railway supplies were shipped into Fairbanks for the construction of the Tanana Valley Railroad, a privately-owned and operated narrow-gauge railway that connected the mines with Fairbanks (see Figure 2.8). ${ }^{8}$ The Tanana Valley Railroad alleviated some of the financial pressures placed on the miners by the high costs charged by Fairbanks freighting outfits for shipping supplies to the mines. Shipping from Fairbanks to the mines, a distance of about twenty miles, cost almost the same as the shipping cost of the item from Seattle to

\footnotetext{
${ }^{8}$ Alfred Brooks, Alaska, The Engineering and Mining Journal, Vol 79 (1905) 16-18.
} 
Fairbanks. ${ }^{9}$ The lower cost of shipping initiated by Tanana Valley Railroad increased the purchase and transportation of large boilers, hoists and other machinery to the mines, which accelerated the development of the Fairbanks district.

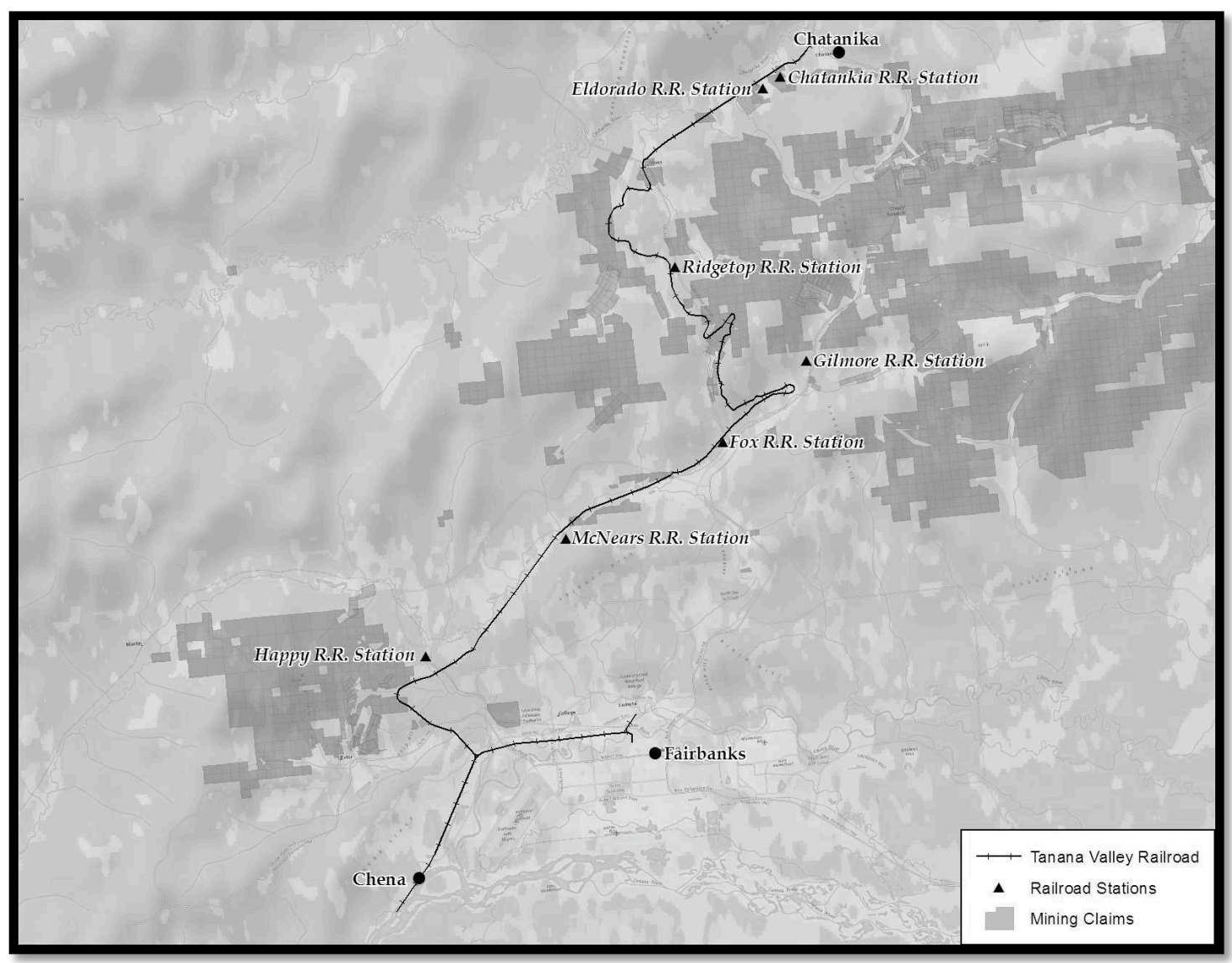

Figure 2.8: Tanana Valley Railroad (Baeten: 2012 - Digitized from Prindle \& Kat2, 1913)

The advent of the Tanana Valley Railroad and the introduction of large machinery to the mines sparked an increase in production and exploration within the Fairbanks Mining District. In 1903, placer mining in the Fairbanks district

\footnotetext{
${ }^{9}$ Purington, Methods and Costs of Gravel and Placer Mining in Alaska, 227. Purington states that in 1903, a miner shipped a boiler to Pedro Creek at a loss of $\$ 300$. By 1908 the cost of shipping supplies to the mines dropped from " 25 cents a pound in the summer to just a few cents"
} 
yielded a total of around $\$ 40,000$, by 1906 that number grew to $\$ 9,000,000 .^{10}$ Additionally, active mining increased from mines on six creeks producing placer gold 1903 to mines on twenty creeks, four years later. ${ }^{11}$ In 1907, the mining activity in the Fairbanks district was still relatively low-capacity, most of the technologies implemented were similar to those used in 1903. Of the roughly 300 operating mines in 1907, $85 \%$ were involved with drifting while the remainder conducted open-cut mining. ${ }^{12}$ Drift mining operations were more cost intensive and employed more men per mine on average than open-cut mining. ${ }^{13}$ Drift mines required underground and surface infrastructures, making the initial investment much higher than open-cut mining. By 1907, foundries and machine shops had opened in Fairbanks that tailored equipment specifically for the local mining conditions, further reducing the overhead cost of equipment for the mines. $^{14}$

The output of placer gold in the Fairbanks district remained nearly the same until 1910, when it tapered off to about $\$ 6,000,000$. After 1910 , the production of placer gold in the Fairbanks Mining District continued to fall,

\footnotetext{
${ }^{10}$ L.M. Prindle, "A Geologic Reconnaissance of the Fairbanks Quadrangle, Alaska", USGS Bulleting No. 525 (Washington: GPO, 1913) 111-112.

${ }^{11}$ L.M. Prindle, "Gold Placers of the Fairbanks District, Alaska", USGS Bulletin No. 225, Series A Economic Geology, 33 (Washington: GPO, 1904) 68. The 6 producing creeks in Fairbanks in 1903 were: Pedro, Twin, Cleary, Chatham, Wolf and Fairbanks Creek. By 1907 many small tributaries of Cleary, Pedro and Fairbanks Creek were opened to mining along with the Ester region in the Eastern region of the Fairbanks Mining District.

${ }^{12}$ L.M. Prindle and F.J. Katz, "The Fairbanks Gold Placer Region”, USGS Bulletin No. 379 (Washington: GPO, 1908) 192.

${ }^{13}$ L.M. Prindle and F.J. Katz, "The Fairbanks Gold Placer Region”, 195. To get a new drift mine operation started in 1907, cost around \$12,000. A drift mine on Ester Creek employed 46 men in 1907.

${ }^{14}$ L.M. Prindle and F.J. Katz, "The Fairbanks Gold Placer Region”, USGS Bulletin No. 379,193.
} 
reaching a low of about 17,000 ounces valued at $\$ 350,000$ in $1927 . .^{15}$ The decrease in production reflected the local conditions of the area. Water shortage, labor unrest from declining wages and the exhaustion of some of the richest deposits were all contributing factors to the decline of the district. Additionally, miners practiced selective mining; they were concerned only with the richest paystreak, and often discarded lower grade auriferous material with the tailings. ${ }^{16}$ Early miners' also utilized sluice boxes untreated with mercury as their primary means of gold recovery, losing fine gold that would have been captured with the introduction of mercury, which produces an amalgam.

Mines generally experience a boom period followed by a period of decline. The period of decline often defines a mining district, as it generally lasts longer than the boom period; miners can continue utilizing traditional techniques and technologies, or adapt new technologies to the changing conditions of the deposit. Placer miners in Fairbanks followed the latter, incorporating new technologies geared towards harvesting the waste-gold found in lower-grade auriferous material. Post-1910 placer mining in the Fairbanks region saw the introduction of dredges and large earthmovers and the construction of intricate systems of ditches. By 1928, six large dredges were installed in the Fairbanks district that brought the gold value for that year back to nearly a million dollars. ${ }^{17}$ These innovations helped the Fairbanks district become Alaska's leading producer of placer gold.

Settlements were established adjacent to many of the paying creeks in the Fairbanks Mining District. Gilmore, Golden City, Meehan, Cleary, Olness, Dome,

\footnotetext{
${ }^{15}$ James M. Hill, "Lode Deposits of the Fairbanks District, Alaska", USGS Survey Bulletin 849-B, (Washington: GPO,1933) 48.

${ }^{16}$ Norman L. Wimmler, "Placer-Mining Methods and Costs in Alaska", Bureau of Mines Bulletin No. 259 (Washington: GPO, 1927) 8.

${ }^{17}$ Philip Smith, "Mineral Resources of Alaska, 1928”, USGS Survey Bulletin 813 (Washington: GPO, 1930)47.
} 
Eldorado and Vault were all towns incorporated by 1907 (see Figure 2.9). Many of the settlements were supplied with electricity and were connected to Fairbanks and the mines by phone service, rail line and wagon road. They had roadhouses, hospitals, fire departments, jails, banks, saloons, hotels, post offices, churches and supply stores. ${ }^{18}$ Populations in these towns varied from fifty to a thousand residents consisting of prospectors, speculators, miners and their families. These settlements grew quickly and dissipated at a similar speed. The prospectors who called towns like Golden City home followed a transient lifestyle. They chased ephemeral deposits from creek to creek, with the majority working as wage laborers for the wealthy speculators who staked the majority of the claims in the Fairbanks region. The prospectors' history, like the fine gold they mined, was also ephemeral. The landscape reflects only a small footprint of their residency: small tent pads and lean-tos, collapsed one-room cabins and can dumps, privy holes. Traditional manual placer mining methods leaves little telltale signs of excavation, transportation or processing on the landscape. However, the social and economic effects of placer mining in the Fairbanks Mining District had lasting effects.

\footnotetext{
${ }^{18}$ Matheson and Haldmen, "Historic Resources in the Fairbanks North Star Borough", 40-45.
} 


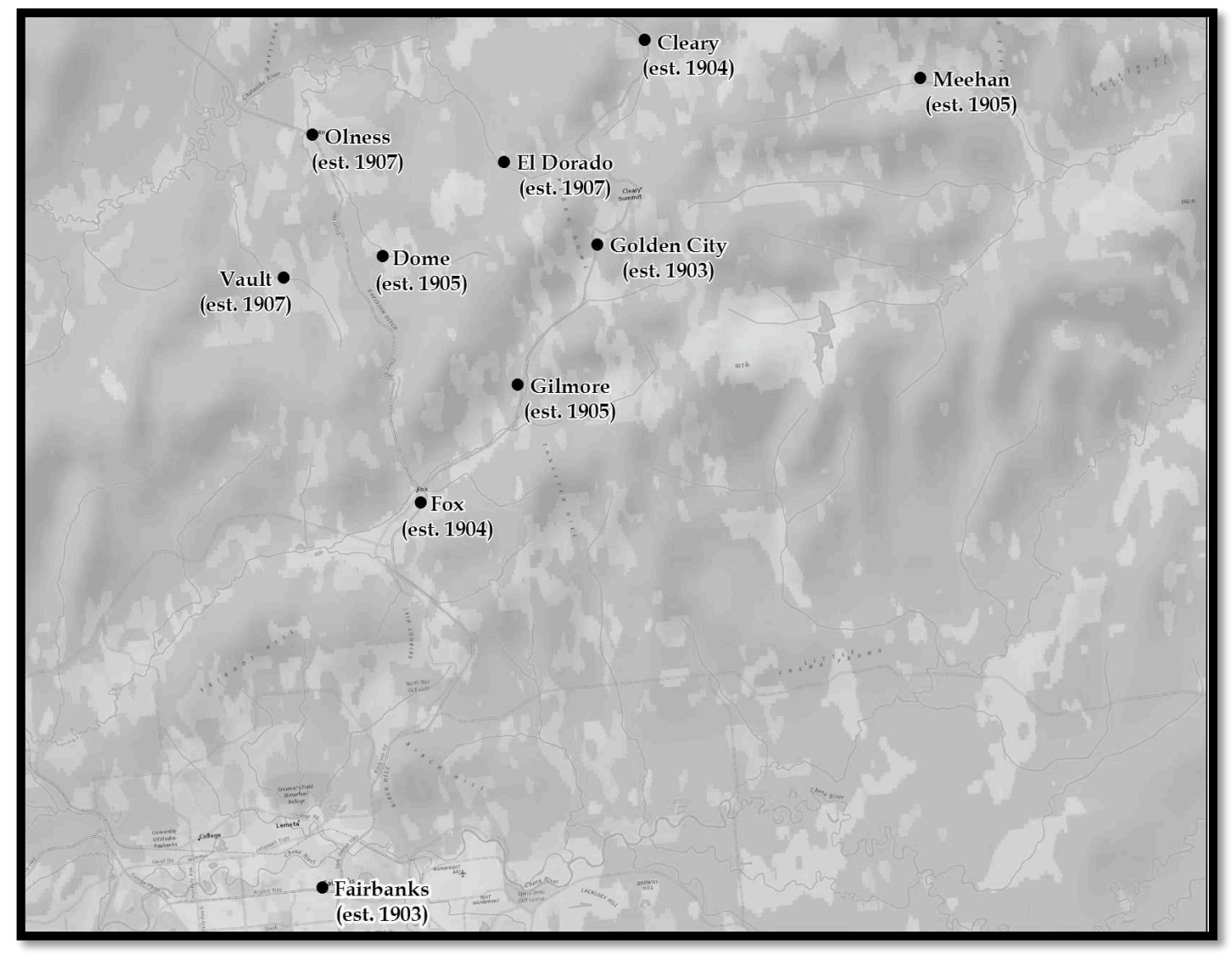

Figure 2.9: Overview of Settlements Within the Fairbanks Mining District (Baeten: 2012)

By 1960, the placer gold output of the Fairbanks Mining District outproduced the total beach diggings at Nome by over a million ounces, and made up about $40 \%$ of the total placer gold production in Alaskan history. ${ }^{19}$ The success of the district was due to three factors: the miners of the early years, who prospected with pick and pan up the valleys of the Tanana; the advent of transportation systems that facilitated the introduction of boilers, hoists and thawing implements to the mines; finally the introduction of large-scale dredging

${ }^{19}$ Edward H. Cobb, "Placer Deposits of Alaska", USGS Survey Bulletin 1374 (Washington: GPO, 1973) 128. Nome, located in the Seward Peninsula, was one of the first mining districts to actively dredge in Alaska, and in turn, was a leading producer of placer gold from the turn of the century until the 1940s. 
operations in 1928. Felix Pedro and E.T. Barnette are credited as the founders of Fairbanks, but it was the miners from Dawson, whose years of experience digging in the frozen gravels of the Klondike that made the Fairbanks District a success. 
"Even the lowly earthworm does his part toward preparing the placer deposit for the lucky miner"

Prospecting for Gold and Silver, Eros M. Savage 1934

\section{Chapter 3: Placers}

This chapter describes the geological processes responsible for the creation of placer deposits found in Alaska. Emphasis is placed on the formation of placers; the history of their formation often impacted the mining technologies used to exploit them. A placer is a concentrated deposit of valuable minerals that has been displaced form its original source vein and redeposited elsewhere. A placer deposit is the result of the displacement of minerals by the natural weathering of the earth's surface. Placers are formed when wind, water or gravity displace the mineral deposit and redeposit it elsewhere. The primary force involved in the creation of placers in the Fairbanks district is running water, with the resulting deposit referred to as alluvium. Alluvial deposits occur when mineral bodies are eroded, displaced and redeposited by running water. ${ }^{1}$ In the United States these deposits are called placers, and I will use the term placer when describing mineral deposits that are unconsolidated. The minerals within the placer deposit will be described as alluvium or gravels and the material that is economically valuable as auriferous material. ${ }^{2}$

The native gold found within a placer deposit originally was part of a larger rock body, a quartz vein, which contained lode gold. Running water disintegrated the rock body, loosening chunks of gold bearing rock and transporting them along the bottom of the creek bed. The natural weathering of the placer deposit milled the gold over thousands of years of erosion, liberating the precious metal

\footnotetext{
${ }^{1}$ S.V. Griffith, Alluvial Prospecting and Mining (London: Pergamon Press, 1960) 1.

${ }^{2}$ Donald J. Cook, "Placer Mining in Alaska", Mineral Industry Research Laboratory Report No. 65 (Fairbanks: University of Alaska - Fairbanks) 13.
} 
from its adjoining valueless minerals, called gangue. As the stream changes its course, the kinetic energy of the stream lessens, making the heaviest particles of streambed sediment lag behind and concentrate. ${ }^{3}$ Gold is roughly seven times denser than other particles within placer sediments. In its pure state gold has a specific gravity of 19.3 , but gold found within placers is never pure, as it is generally alloyed with some amount of silver. ${ }^{4}$ Placer gold averages a specific gravity between $14-19$, still much heavier than the 2.6 specific gravity found within the remaining sediment matter of the placer. ${ }^{5}$

The weight and density of placer gold lend to its eventual weathering. The heavy gold particles resist moving with the stream flow, and at the same time, their high density assists with in the deposition within the auriferous deposit. ${ }^{6}$ As placer gold settles and concentrates at the bottom of the streambed, water continually rushes over the gold, modifying its shape and pushing it downward towards bedrock. Placer gold varies in size from small particulate matter, called colors or fines, to large globule nuggets. ${ }^{7}$ The heavier pieces of placer gold tend to rest closer to bedrock than the smaller fines, making the most concentrated "pay-dirt" generally nearest to bedrock. ${ }^{8}$ The thickness, or depth to bedrock, of placers can be as little as a few inches to over 600 feet. $^{9}$

\footnotetext{
${ }^{3}$ Savage, Prospecting for Gold and Silver, 4-8.

${ }^{4}$ Theodore F. Van Wagenen E.M., Manual of Hydraulic Mining for the use of The Practical Miner (New York: D. Van Nostrand, 1880) 14.

${ }^{5}$ Cook, Placer Mining in Alaska, 25.

${ }^{6}$ Louis M. Prindle, "The Fairbanks and Rampart Quadrangles Yukon-Tanana Region, Alaska", USGS Bulletin No. 337 (Washington: GPO, 1908) 34.

${ }^{7}$ John S. Hittell, Mining in the Pacific States of North America (San Francisco: H.H. Bancroft \& Co., 1861) 44-45.

${ }^{8}$ Augustus J. Bowie, A Practical Treatise on Hydraulic Mining in California (New York: D. Van Nostrand Co., $1905,10^{\text {th }}$ ed.) 71.

${ }^{9}$ Eugene B. Wilson, Hydraulic and Placer Mining (New York: John Wiley \& Sons, 1900) 16-17.
} 
The depth of the placer reveals information for determining if the deposit could be profitably exploited as well as what mining technique should be employed; these varying techniques and technologies will be discussed in detail later.

Placers occur in a variety of locations dependent on where the stream courses concentrated them. Types of placers include: creek, bench, gulch, beach, lakebed, conglomerate, deep lead, and broad-valley deposits. ${ }^{10}$ Placer deposits in Alaska can be categorized into three primary groups: residual, sorted and resorted, based on how they originally became unconsolidated. These groups can be further classified based on the age of the deposit and its location. ${ }^{11}$

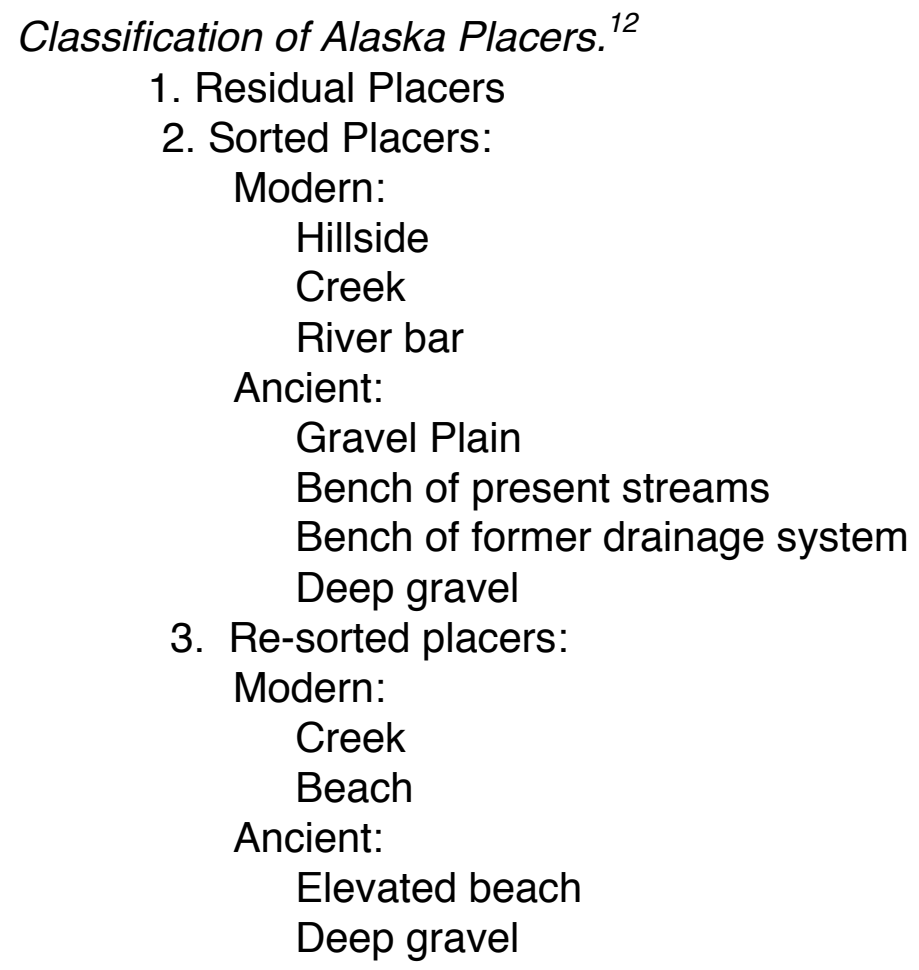

\footnotetext{
${ }^{10}$ Eros M. Savage, Prospecting for Gold and Silver (New York: McGraw-Hill, 1934)10-16.

${ }^{11}$ Alfred H. Brooks, "Mineral Resources of Alaska, Report on Progress of Investigations in 1913", United States Geological Survey (USGS) Bulletin 592 (Washington: GPO, 1914) 27-32.

${ }^{12}$ Brooks, Mineral Resources of Alaska 29.
} 
Residual placers are deposits that have undergone extreme weathering, where the rock body has experienced physical and chemical changes, generally comprising of the loss of non-valuable material. ${ }^{13}$ Residual placers generally experience little displacement from running water and are found at a close proximity to the source vein. ${ }^{14}$

Sorted placers are those that have been dispersed and concentrated by water. ${ }^{15}$ Sorted placers dominate the deposits found in most stream and bench placers, as well as the extremely deep ancient placers exploited by underground methods. Sorted placers are the predominant form found in the Fairbanks Mining District.

Resorted placers are sorted placers that have undergone multiple periods of erosion prior to their final deposition. ${ }^{16}$ Resorted placers occur due to modern alluvial activity displacing placers and reconcentrating them. ${ }^{17}$ These types of deposits are most common in beach and creek placers, where tidal action creates a constant displacement.

Placer deposits give clues to where potential lode gold deposits, found in a vein body, might be located, generally upstream of the placer deposit. ${ }^{18}$ The relative shape of the gold found within the placer deposit provides information on the proximity of the original host rock, called the mother lode. Angular gold and large nuggets tend to be closer to the primary source, as they have been worn

\footnotetext{
${ }^{13}$ Eoin H. MacDonald, Alluvial Mining, The geology, technology and economics of placers (London: Chapman \& Hall, 1983) 113-115.

${ }^{14}$ Brooks, Mineral Resources of Alaska 29.

${ }^{15}$ Brooks, Mineral Resources of Alaska 28.

${ }^{16}$ Brooks, Mineral Resources of Alaska 28-31.

${ }^{17}$ Brooks, Mineral Resources of Alaska, 30.

${ }^{18}$ Edward Cobb, "Placer Deposits of Alaska", USGS Survey Bulletin 1374 (Washington: GPO, 1973) 1.
} 
down to a lesser degree by the erosive streambed than the small fines. ${ }^{19}$ However, a large deposit of angular placer gold does not necessarily mean that a primary lode source is adjacent. Additionally, the primary source of the placer gold could be a lower-grade deposit, or even completely disintegrated, depending on the extent of the weathering. ${ }^{20}$ Nevertheless, prospectors who discovered gold in streambeds worked the placer upstream searching for the mother lode.

\section{Mining Techniques/Equipment}

Traditional placer mining is commonly referred to as poor-man's mining, due to the lack of sophisticated tools necessary to successfully obtain the precious metal. ${ }^{21}$ Placer miners utilize a variety of techniques and equipment to exploit the local deposit. Differences in placer mining techniques generally relate to the depth of the deposit to bedrock, the availability of water and the grade of the alluvium being mined. This section will focus on the general techniques and equipment used in the small-scale extraction of stream and bench placers. In addition, a brief description of hydraulic mining and dredging is included.

Panning: Panning utilizes simple hand tools and is the preferred method used in initial prospecting. ${ }^{22}$ The main tool in panning is its namesake, the gold pan. The gold pan is a shallow metal dish, generally 10 "-18" in diameter, with sloping sides and a concave or flat bottom (see Figure 3.1).

\footnotetext{
${ }^{19}$ Robert Peele, Mining Engineers' Handbook (New York: John Wiley \& Sons, 1927) 886.

${ }^{20}$ Cook, Placer Mining in Alaska, 14.

${ }^{21}$ A.C. Harris, Alaska and the Klondike Gold Fields (Toronto: Coles Publishing Co., 1897, facsimile published1972) 375-376.

${ }^{22}$ Chas. F. Jackson, "Small Scale Placer-Mining Methods", Bureau of Mines Technical Paper 591 (Washington: GPO 1938). Miners also applied mercury to copper pans, rocker plates and sluice boxes. Mercury creates an amalgam with fine gold that is easily recovered. For an overview on treating plates with mercury see Savage (42) and Peele (1927-1931).
} 


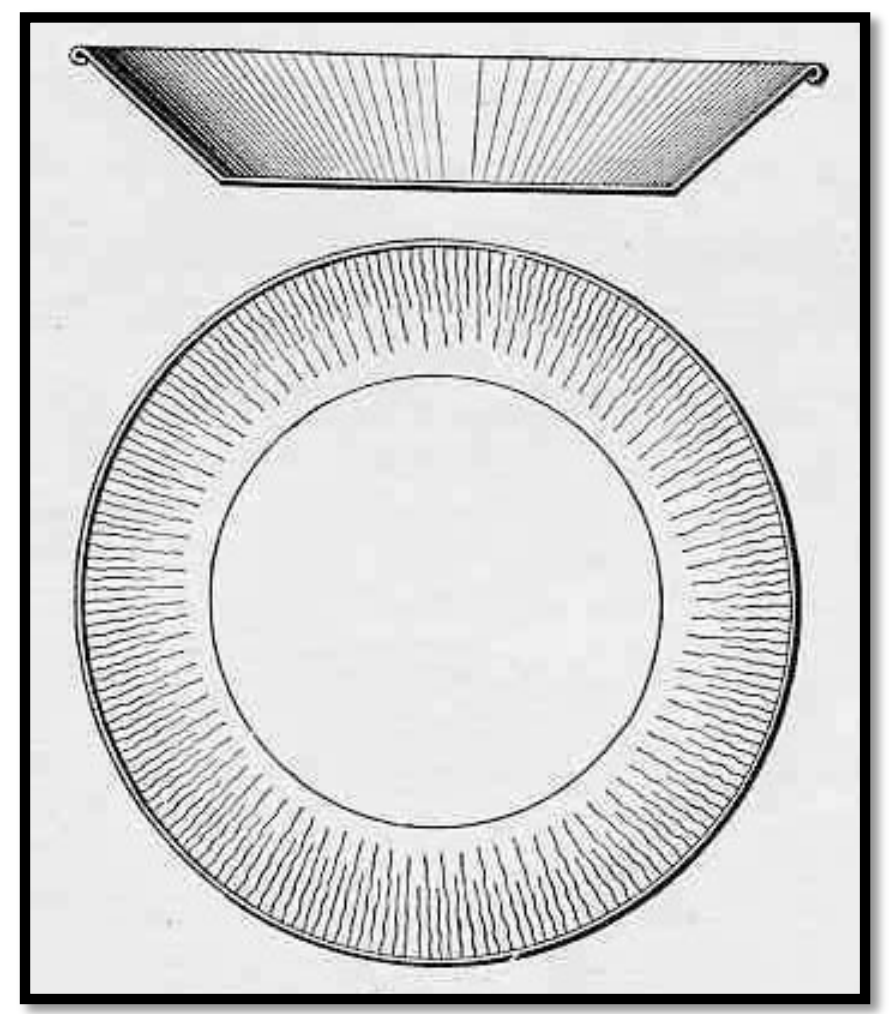

Figure 3.1: Gold Pan (Wilson 1900:23)

Gold panning consists of filling the pan with alluvium, placing it in water and agitating the sediment by hand. Doing so breaks up the clay and conglomerate sand and assists the gold in settling to the bottom of the pan. Next, the pan is grasped with two hands, and in a circular motion the miner shakes the pan sideto-side. This process allows the lighter gangue sediment to dissipate and spill over the sides of the pan, while the heavier valuable particles remain in the pan's base. This process is repeated until there is only a small amount of material left in the pan. The miner sorts through this material with his fingers, examining it for pieces of gold larger than fines. The remaining matter, consisting primarily of gold and black sand, is left in the pan to dry. Once dry, the gold is separated from the gangue material by either blowing or by running a magnet across the 
material. ${ }^{23}$ An experienced miner with an ample water supply can work around 100 pans in a day, about 0.6 cubic yards of dirt. ${ }^{24}$

Rocker: The rocker is a tiered wooden box, situated on an incline, used to wash and sort alluvium (see Figure 3.2).

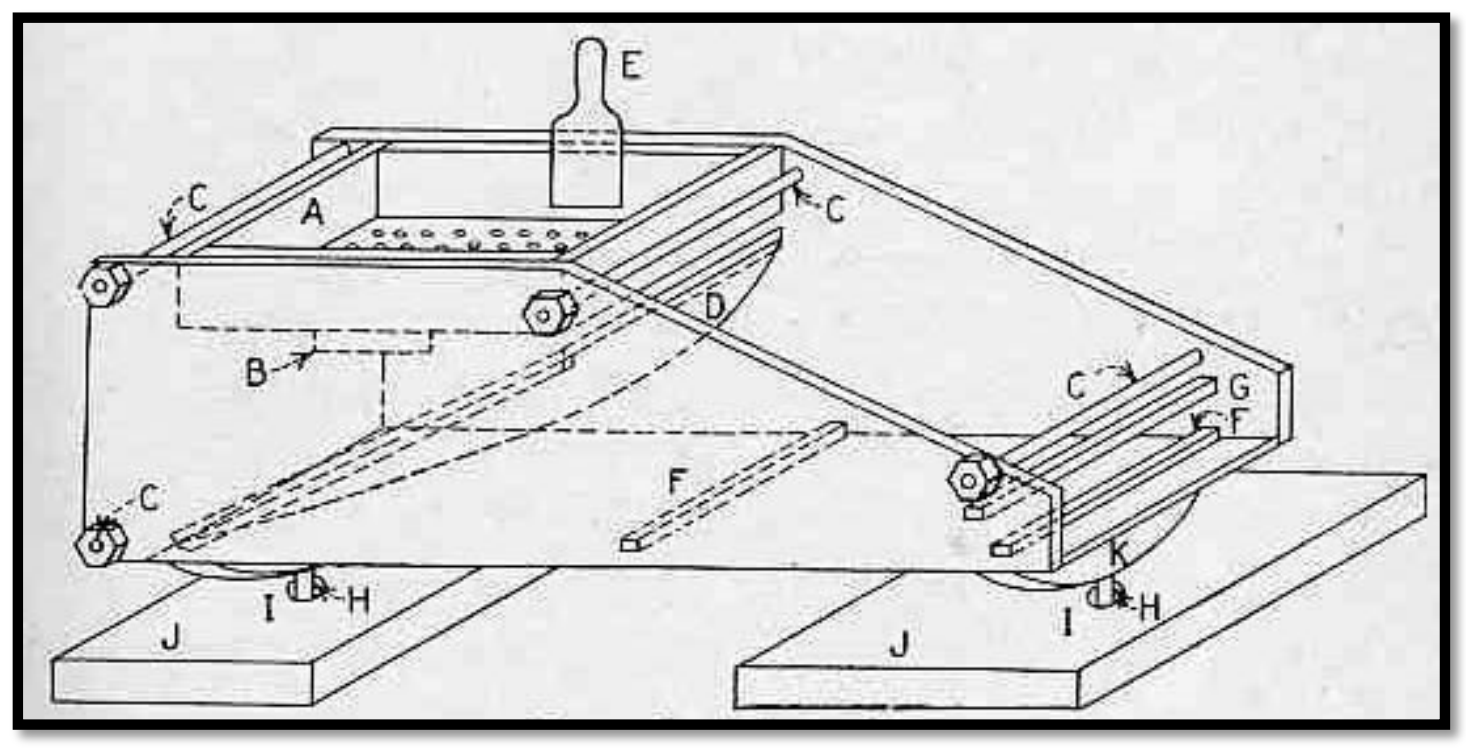

Figure 3.2: Rocker box (Savage 1934:39)

The rocker box functions best when used by two miners, one engaging the box, while the other shovel alluvium into the box. The upper level of the rocker box is basically a screen, an open tray with a perforated bottom (see A, Figure 3.2). ${ }^{25}$ The alluvium is shoveled onto the screen of the rocker and miners add water to help disintegrate the mixture. A handle located on the side of the screen is used to agitate the device in a rocking motion (see E, Figure 3.2). As the screen is

\footnotetext{
${ }^{23}$ Peele, Mining Engineers' Handbook, 887.

24 Peele, Mining Engineers' Handbook, 887.

${ }^{25}$ Historically the screen in the rocker could be constructed out of either perforated iron or a series of parallel bars, known as a grizzly. The latter of the two seems to have become less popular as mining techniques progressed. For detailed descriptions see Wilson, Savage and Peele.
} 
shaken the alluvium passes through the screen and falls onto a sloping surface called an apron (see D, Figure 3.2). The apron is used to catch the heavier pieces of alluvium that pass through the screen. The apron is covered with canvas, miner's moss, or carpet, which is left loose, creating small pockets that capture most of the gold. ${ }^{26}$ The alluvium that passes over the apron falls onto the inclined base of the rocker box. The base is a flat surface that is affixed with 2-3 perpendicular strips, called riffles (see F, Figure 3.2, Figure 3.3).

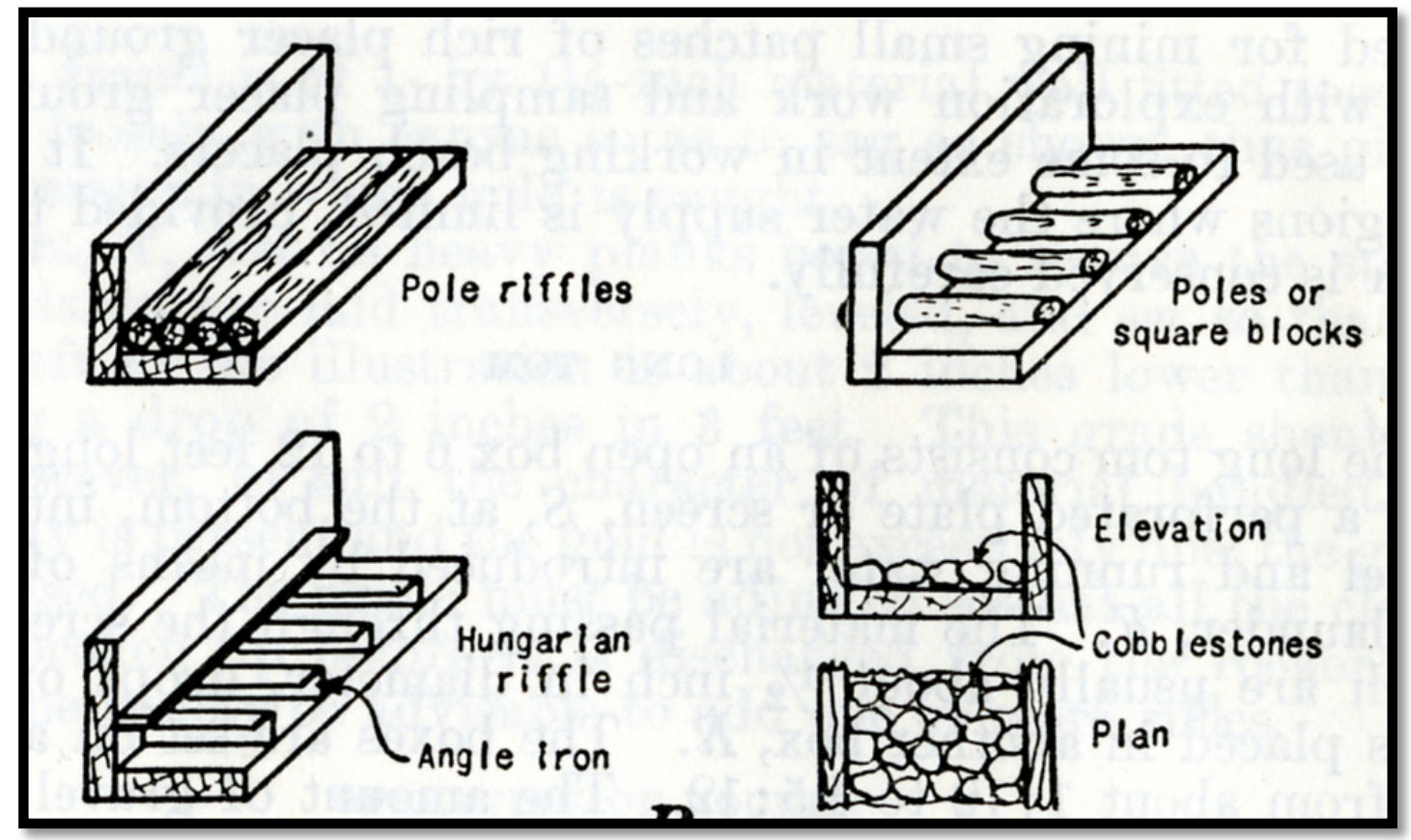

Figure 3.3: Examples of riffles (Jackson 1938:36)

These riffles are generally 1" wide and 3/4" high and are used to collect the remaining heavy material that passes through the screen and apron. ${ }^{27}$ The base of the rocker box is affixed to a plank that is bolted onto 1-2 "rockers". The rockers are rounded blocks of wood that assist in agitating the alluvium, allowing

\footnotetext{
${ }^{26}$ Savage, Prospecting for Gold and Silver, 41.

27 Jackson, Small-Scale Placer Mining, 34. Riffles vary in composition, from wooden planks to rough stones. For a complete overview of riffles see Peele (915-921) and Jackson (40-41).
} 
the device to move both front-to-back and side-to-side. After the alluvium runs through the rocker box, and the water exiting the screen is clear, the apron is removed and its contents, along with the build-up behind the riffles, are transferred to the gold pan for the final cleanup. The debris from the rocker is generally captured either in a pit, dug adjacent to the discharge end, or by a trench that sends the debris away from the washing point. Two men working a rocker can process between three to five cubic yards of gravel in a 10-hour day. ${ }^{28}$

Long Tom: The long tom consists of three, tiered components situated on an incline; a flume that feeds water into the apparatus, a 6-12 foot long open-box with a perforated screen at its discharge end (long tom), and a riffle box that traps the gold (see Figure 3.4). ${ }^{29}$

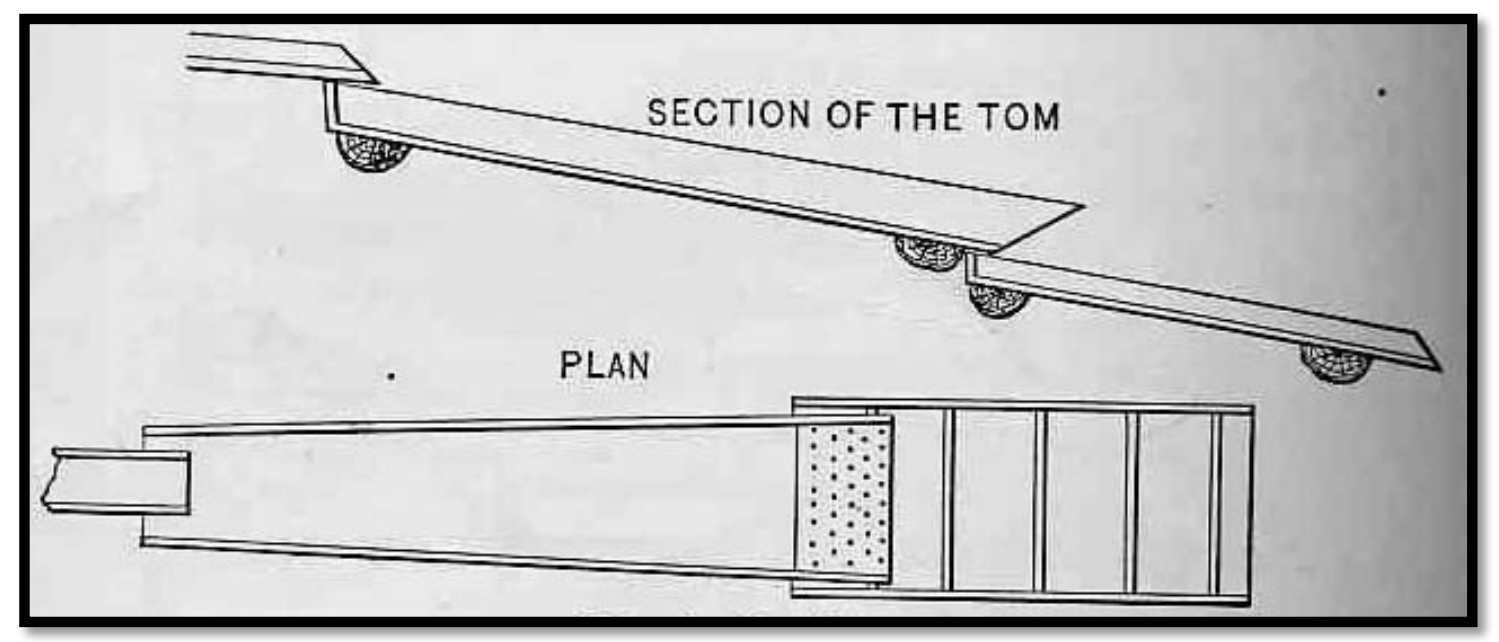

Figure 3.4: Long tom (Bowie 1905:204)

The discharge end of the long tom is about $1 / 3$ wider than its opening, allowing the alluvium to disperse as it runs toward the perforated screen. The tiered organization of the long tom assists in the breaking down of the alluvium, as the

\footnotetext{
${ }^{28}$ Chester Wells Purington, "Methods and Costs of Placer Mining in Alaska", USGS Bulletin Number 263 (Washington: GPO, 1905) 56.

29 Jackson, Small-Scale Placer Mining, 35.
} 
larger chunks of alluvium drop, their impact with the lower components of the long tom cause them to further separate. The long tom requires an ample supply of water and up to 4 men for continued use. In addition to shoveling in the alluvium, miners are required to fork-out large rocks caught in the screen and to shovel out the riffle box. Two men working a long tom can process an estimated six cubic yards of gravel in a 10-hour day. ${ }^{30}$

Sluicing: Sluicing is the washing of gravels through a channel used to collect the valuable material (see Figure 3.5). Sluicing essentially replicates and accelerates the natural processes that occurred during the formation of placer deposits in a controlled setting.

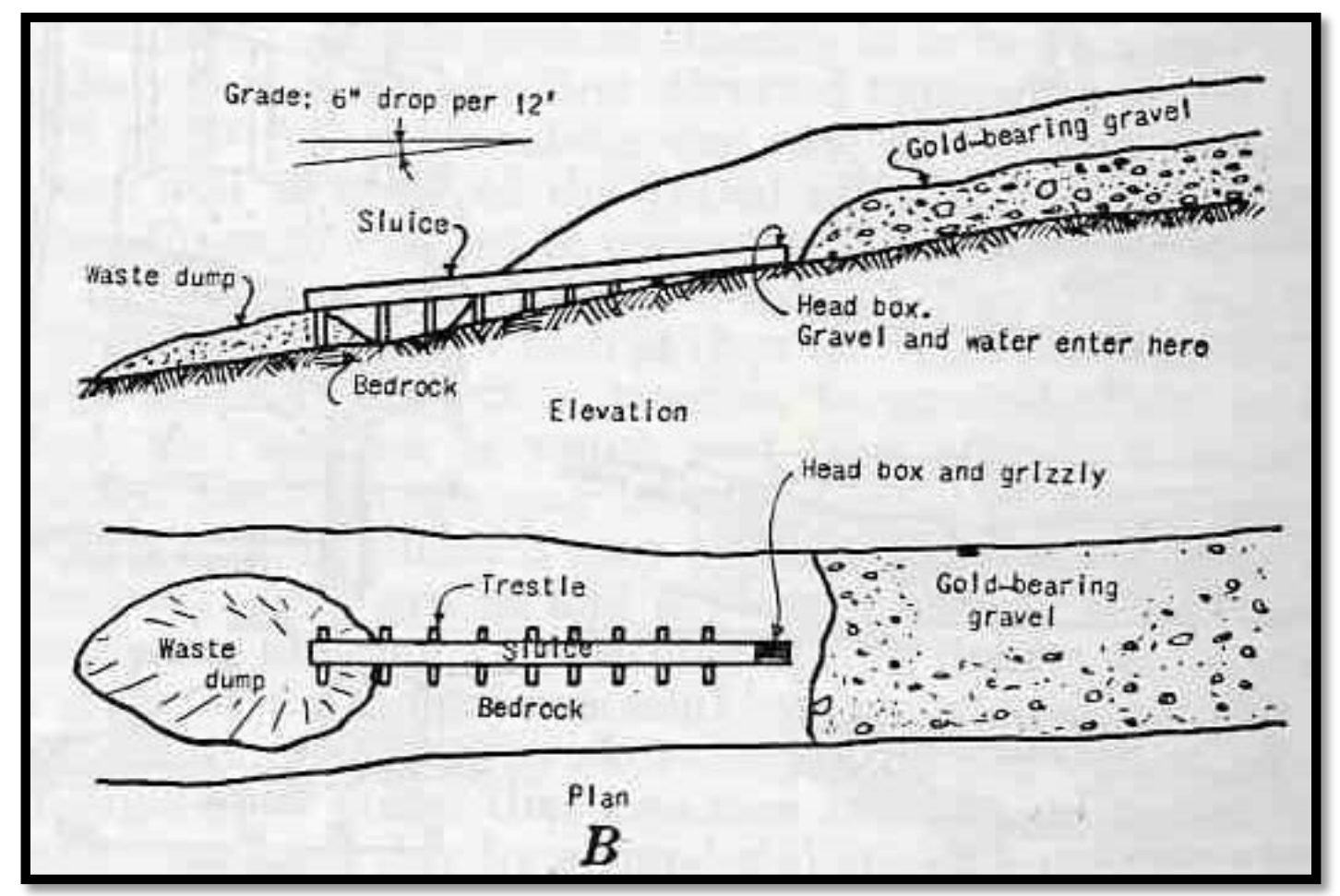

Figure 3.5: Sluicing arrangement (Jackson 1938:40)

${ }^{30}$ Peele, Mining Engineers' Handbook, 889. 
Sluicing occurs on a continual, slight slope, utilizing the forces of gravity to assist in washing the alluvium. Employment of the sluicing method is dependent on an ample supply of water. The sluice box (see Figure 3.6) is the apparatus that captures the valuable material, and is generally an open trough constructed of wood, metal or earth. ${ }^{31}$

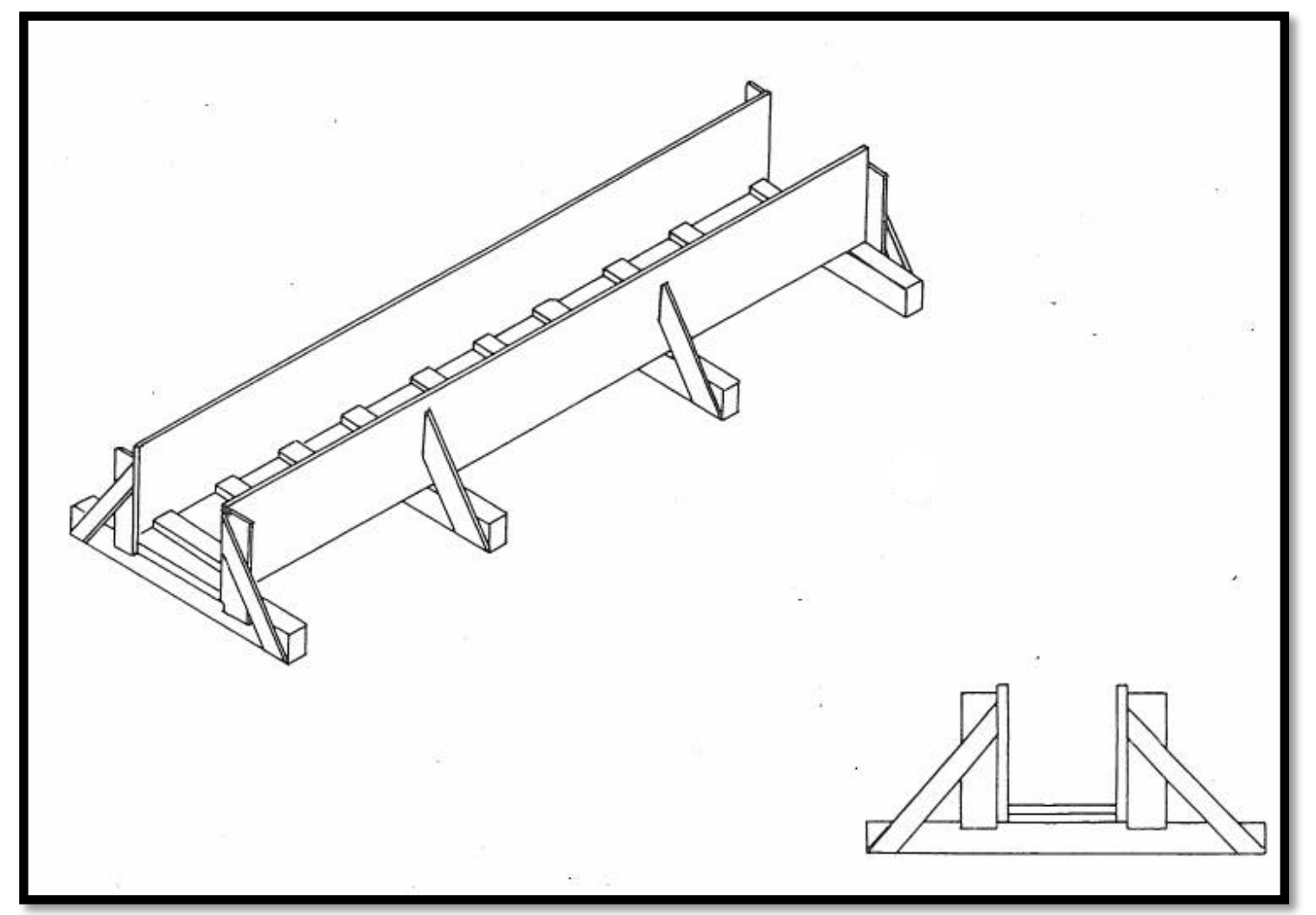

Figure 3.6: Typical sluice box (LaLande 1985:32)

The length of the sluice box is often dependent on the composition of the alluvium being washed. If the alluvium is loose, a shorter sluice box will suffice, if the alluvium is compact, a longer sluice is required. ${ }^{32}$ The typical sluice box is about 24 feet in length with riffles located near the discharge end. Depending on

\footnotetext{
${ }^{31}$ Savage, Prospecting for Gold and Silver, 46.

${ }^{32}$ Robert S. Lewis, Elements of Mining, (New York: John Wiley \& Sons, Inc, 1933) 201. Savage (46) states that the average length of a sluice box varies from 20 to 2,000 feet.
} 
conditions, the sluice is the most efficient means of washing large amounts of alluvium. A variety of methods including: shovel, water, scraper-buckets, wheelbarrows, cars on tracks, buckets and excavators are used to feed the sluice with alluvium.

Undercurrents are a form of sluice used to capture fine gold and to assist the main sluice in further distribution of the gravels. Undercurrents (see Figure 3.7) are much wider than the main sluice, are situated on a steeper grade, and are completely filled with riffles, wood blocks and cobbles. ${ }^{33}$

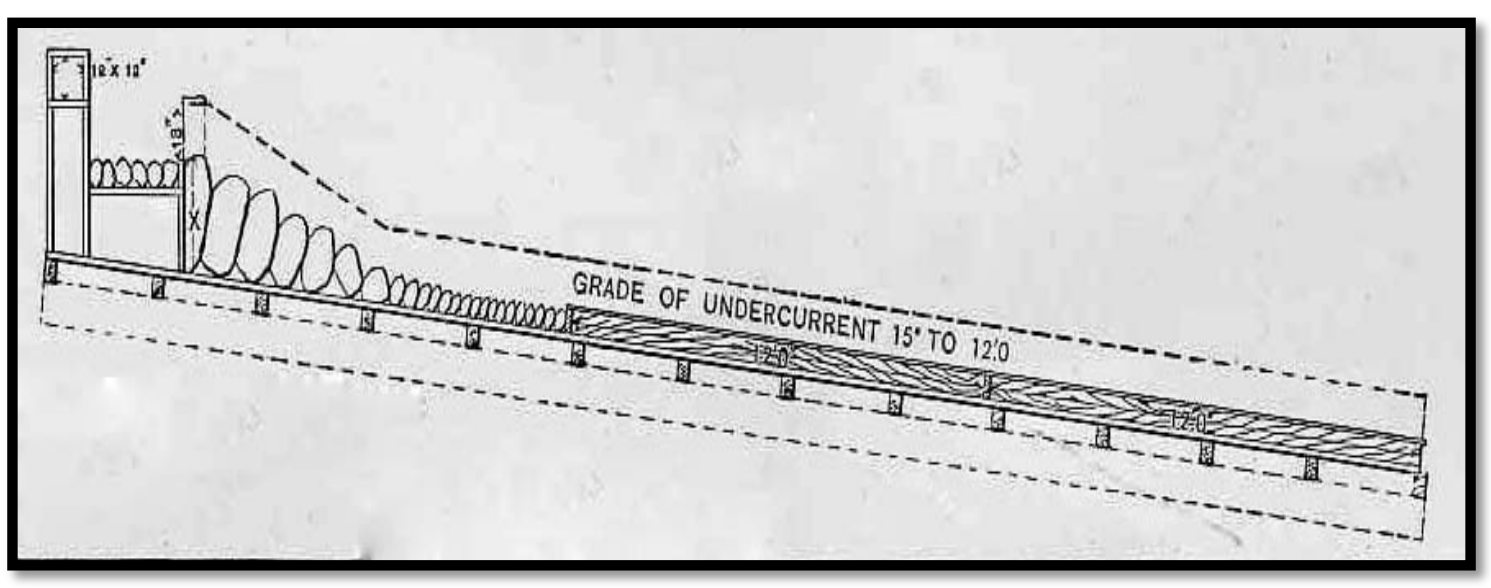

Figure 3.7: Profile of undercurrent (Bowie 1905: Figure 68)

Undercurrents are placed adjacent to the main sluice and partially below. At the intersection of the undercurrent and the sluice a grizzly is placed on the main sluice, allowing the larger rocks to pass over and the finer material to drop into the undercurrent (see Figure 3.8).

${ }^{33}$ Jackson, Small-Scale Placer Mining, 42. 


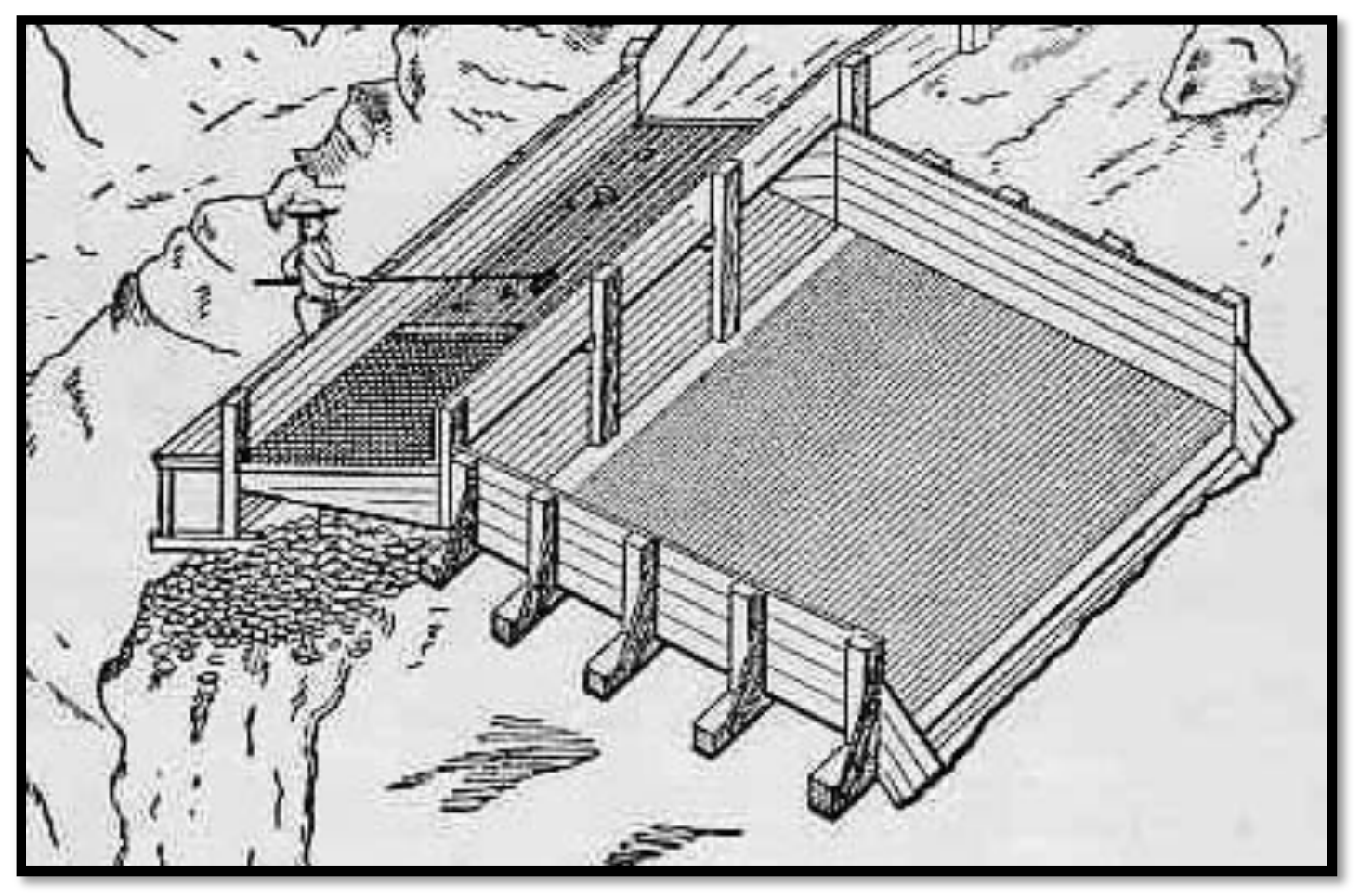

Figure 3.8: Undercurrent arrangement (Wilson 1900:36)

Ground sluicing is a favorable method of washing alluvium depending on the depth of the deposit and the degree of slope. Ground sluicing uses only water and gravity as its means of transporting alluvium through a trench. If an area has a general depth of less than 12 feet to bedrock, ground sluicing is a viable option. ${ }^{34}$ Ground sluicing is often employed as means of preparing the placer ground for scraping or shoveling-in by stripping the area of its overburden, the surface layer of the deposit. ${ }^{35}$ In other instances, the alluvium is either collected by the rough surface of the bedrock, or by the use of a sluice located at the terminus of the trench (see Figure 3.9). If no sluice is used, a rocker works the valuable material left behind in the trench's exposed bedrock. ${ }^{36}$

\footnotetext{
${ }^{34}$ Purington, Methods and Costs of Gravel and Placer Mining in Alaska, 56.

${ }^{35}$ Jackson, Small-Scale Placer mining Methods, 38.

${ }^{36}$ Bowie, Practical Treatise on Hydraulic Mining, 81.
} 


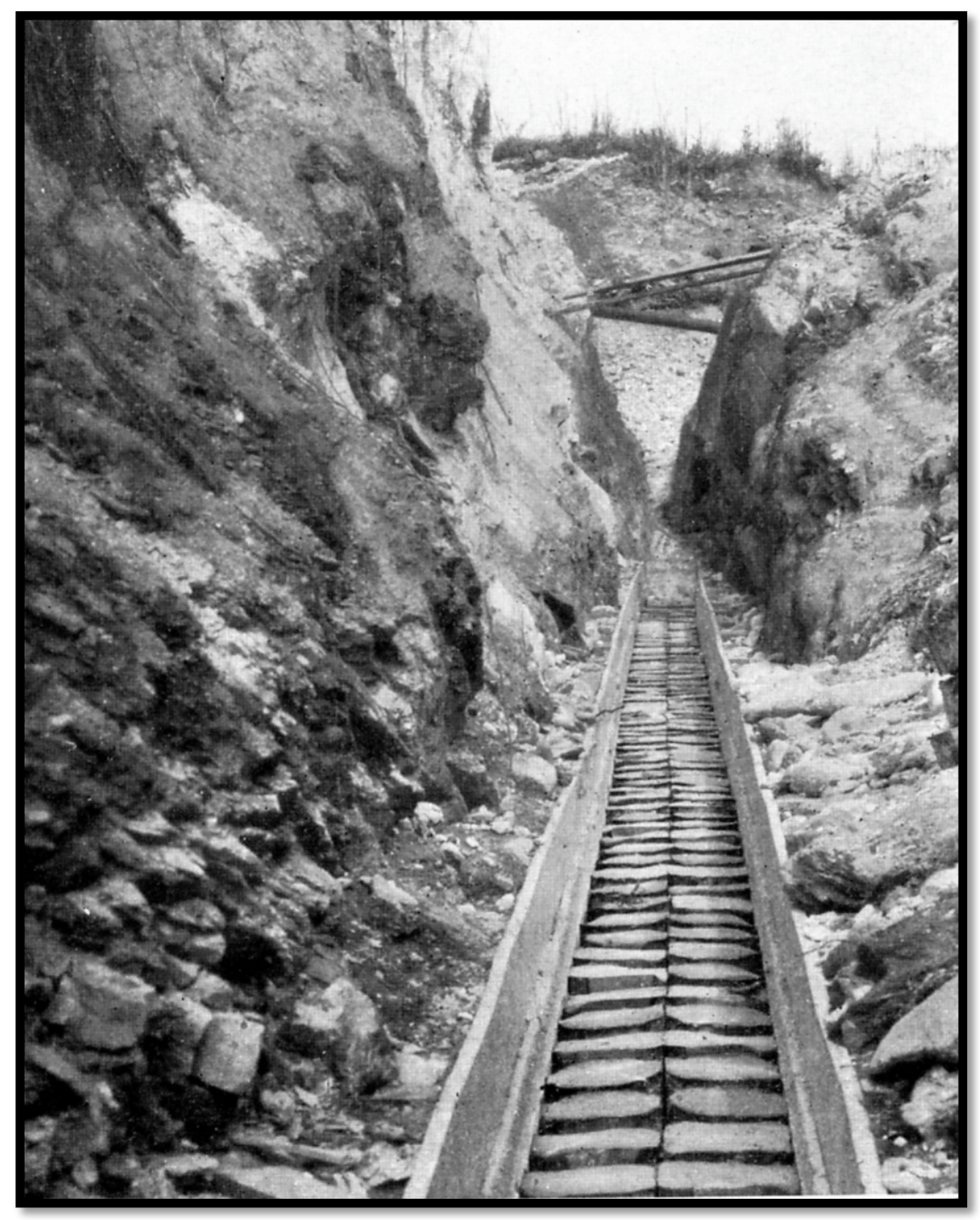

Figure 3.9: Sluice with cobblestone riffles in Alaska (Purington 1905:Plate XXIV)

Booming: Booming is a form of ground sluicing that introduces water to the alluvium through a dam or water battery, located up slope of the placer deposit, which stores water used to wash the alluvium (see Figure 3.10). Once a sufficient amount of water is acquired, a gate is lifted and the water is released. The gate is lifted either by an automated system or manually, sending the turbulent water rushing towards the alluvium in series of torrents called 'booms' ${ }^{37}$

\footnotetext{
${ }^{37}$ Jackson, Small-Scale Placer Mining, 38.
} 


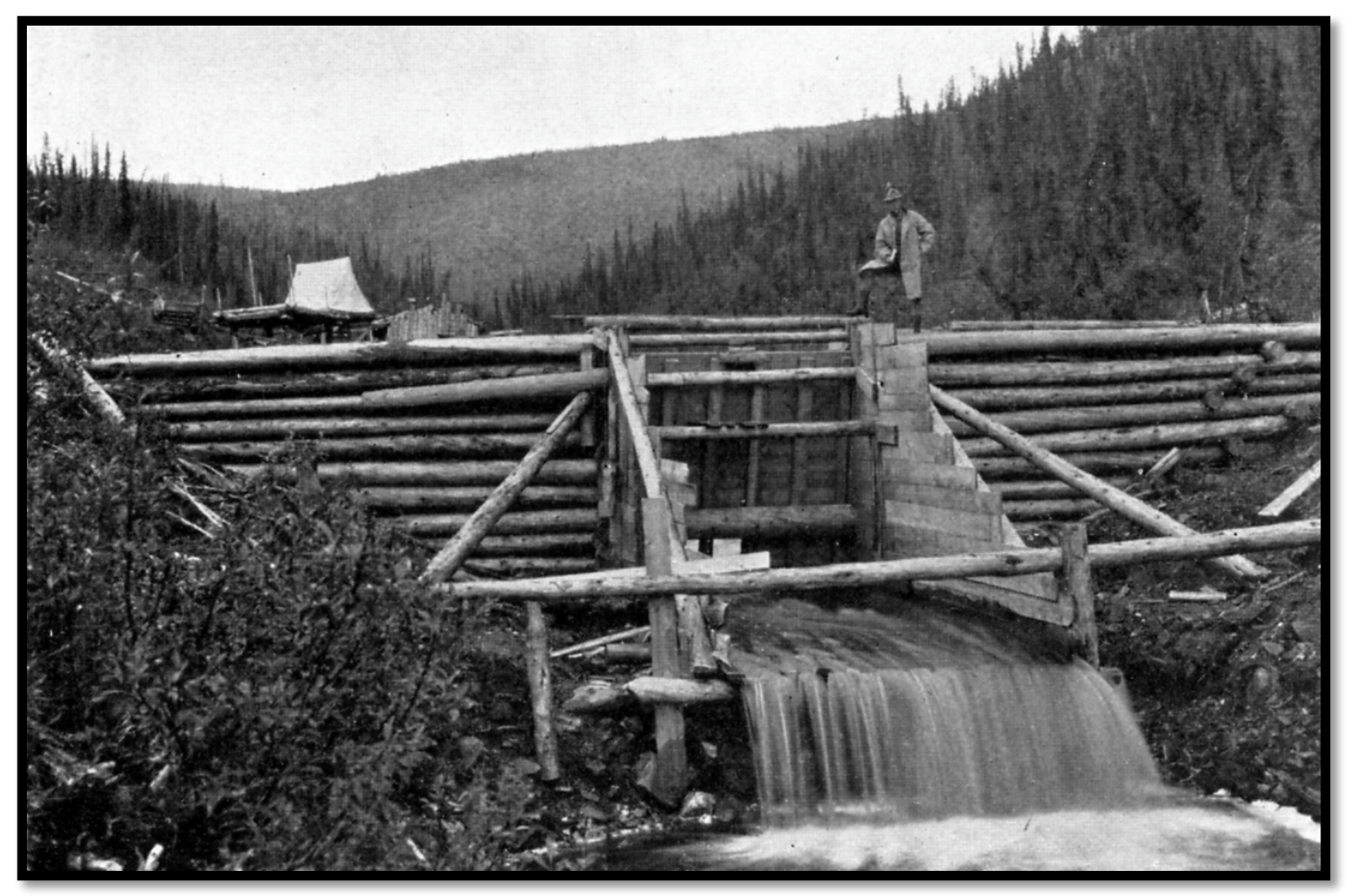

Figure 3.10: Boomer dam (Purington 1905:Plate V)

Drifting: Drifting is a technique used to exploit placer deposits through underground mining techniques. A drift is a horizontal underground mine working that generally runs just above bedrock. Drifting can be carried out either through running a horizontal adit into the side of a bench placer deposit, or by sinking a vertical shaft to bedrock and running horizontal drifts along the paystreak. The latter technique, specifically its implementation in the North, will be covered in detail in Chapter 4. Drifting incorporates similar techniques used in underground hard rock mines, including: the timbered ground-support systems, hoisting apparatus, haulage equipment and dewatering pumps. ${ }^{38}$ The mining technique most often employed in drifting is the retreating longwall method, also called breasting, used extensively in coal mines. ${ }^{39}$ The longwall technique consists of

\footnotetext{
${ }^{38}$ Peele, Mining Engineers' Handbook, 950.

${ }^{39}$ Peele, Mining Engineers' Handbook, 950.
} 
digging crosscuts, perpendicular from the main drift towards the end of the pay streak. Off of the crosscuts additional ancillary drifts are cut, running parallel with the main drift. The sides of the ancillary drifts are mined out and the roof is allowed to collapse as the miners retreat. ${ }^{40}$ The auriferous material that is extracted is hauled out of the main drift by wheelbarrow or mine cars and washed through a sluice. If a shaft was sunk, the material is hauled to the base of the shaft opening and lifted out by a hoist and cable system in an ore bucket. At the surface, the material is either dumped adjacent to the shaft or carried along a cable toward a large pole where it is dumped into an ore chute.

Hydraulic Mining: Hydraulic mining uses a high-pressured stream of water to disintegrate placer deposits. ${ }^{41}$ Hydraulic mining requires an ample amount of water under high head to be economically viable. Additionally, a steep grade of bedrock is required for the alluvium to be moved towards the sluice boxes. ${ }^{42}$ Water for hydraulicking is generally acquired through dams, ditches and flumes that convey water into a series of pipes. These pipes carry the water down to the work area, increasing the pressure of the water as it moves toward the nozzle at the discharge end, called the giant or monitor (see Figure 3.11).

\footnotetext{
${ }^{40}$ Peele, Mining Engineers' Handbook, 950.

${ }^{41}$ For an in-depth overview of hydraulic mining, costs and equipment see Bowie, Purington and Wilson.

${ }^{42}$ Purington, Costs and Methods of Gravel and Placer Mining in Alaska, 99-101.
} 


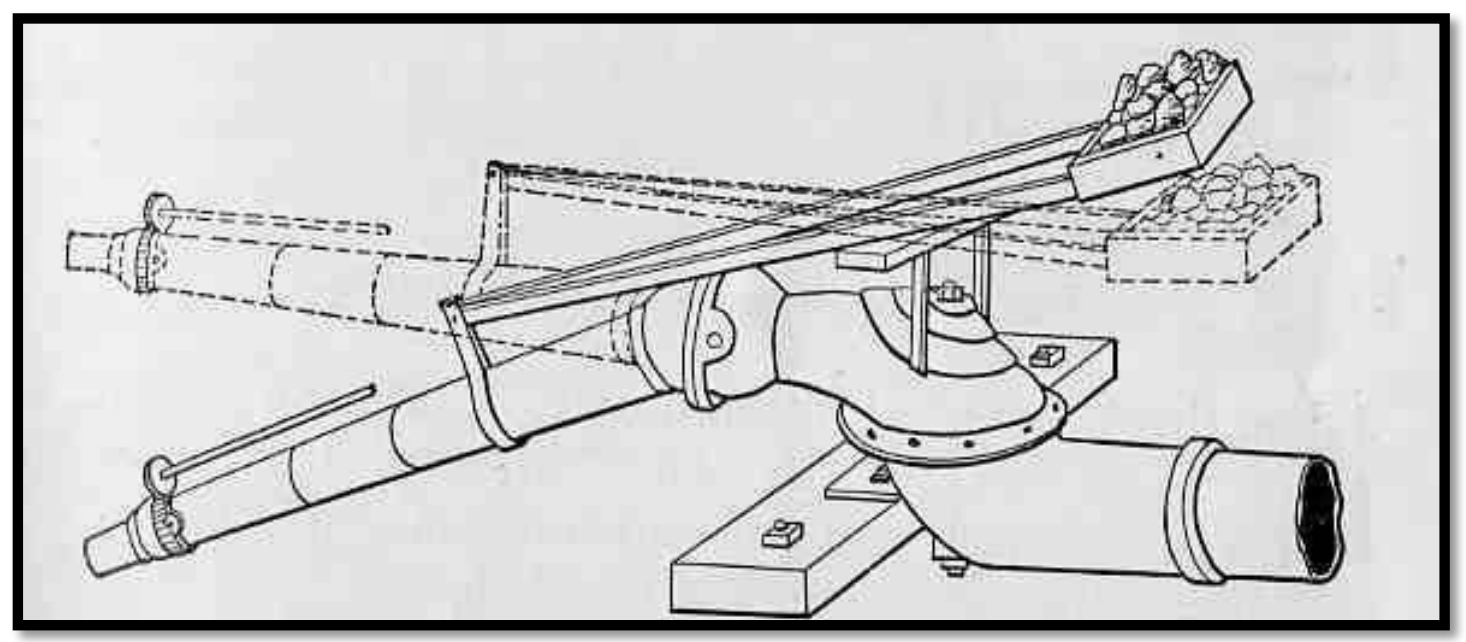

Figure 3.11: Hydraulic Monitor (Bowie 1905:183)

The monitor expels the high-pressure stream of water directly at the face of the placer deposit, tearing off the overburden and caving the alluvium. The flowing water then carries the gravel downslope over the bedrock to a sluice box. The greatest expense in hydraulic mining is generally related to creating the infrastructure used in transporting the water to the pressure pipes (see Figure 3.12). ${ }^{43}$ Once the infrastructure is complete, hydraulic mining is an extremely economically efficient form of washing a large volume of alluvium, since the transportation and excavation are carried out by the same technical procedure. In arid locations this initial expense is generally too great to invest in a hydraulic mining operation.

${ }^{43}$ Jackson, Small-Scale Placer Mining Methods, 44. 


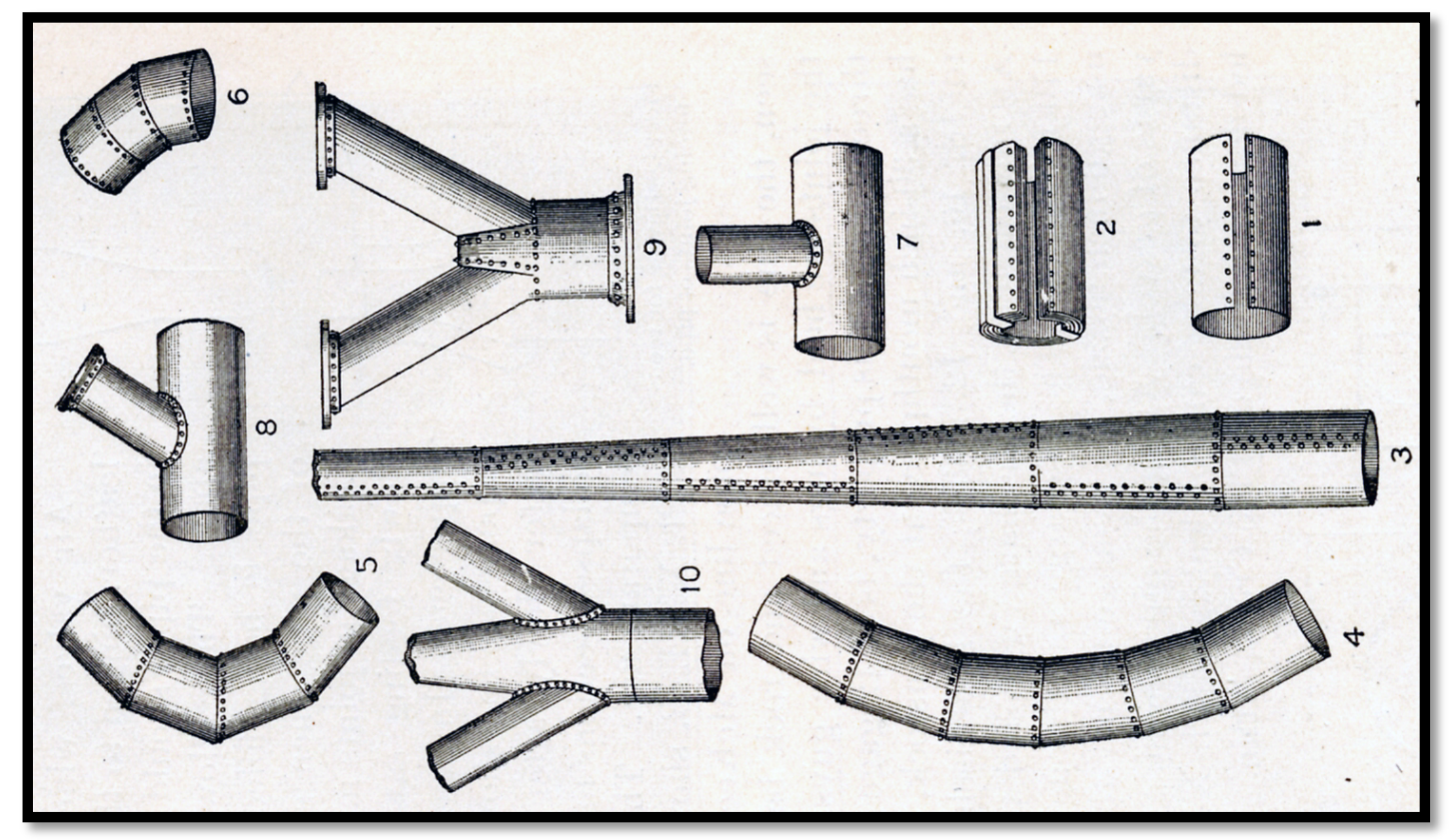

Figure 3.12: Hydraulic pipe segments (Purington 1905:131)

Dredging: Dredging is an advanced form of placer mining that is undertaken in areas with moderately deep deposits that are too flat to work hydraulically. ${ }^{44} \mathrm{~A}$ dredge is an all-encompassing washing plant that excavates, sorts, washes the alluvium, and discards the tailings in a single stream process (see Figure 3.13). The majority of dredges are located on water, especially those in the Alaskan placer fields, where they are affixed to a barge or scow. Dredges are a high cost, high output form of mining. ${ }^{45}$ The elevator bucket dredge is the most prevalent form associated with large-scale placer mining, while the suction dredge is common in smaller operations. ${ }^{46}$ The elevator bucket dredge utilizes a line of

\footnotetext{
${ }^{44}$ Purington, "Costs and Methods of Gravel and Placer Mining in Alaska", 157-158.

${ }^{45}$ For a comparative analysis of dredging output and cost see Peele (930-949) and Purington (167-173).

${ }^{46}$ Eugene D. Gardner, "Placer Mining in the Western United States", U.S. Bureau of Mines Information Circular 6788 (Washington: GPO, 1935) 47.
} 
large steel buckets attached to a belt or chain conveyor system (elevator), scraping the bottom of the subaqueous deposit (see Figure 3.14). ${ }^{47}$

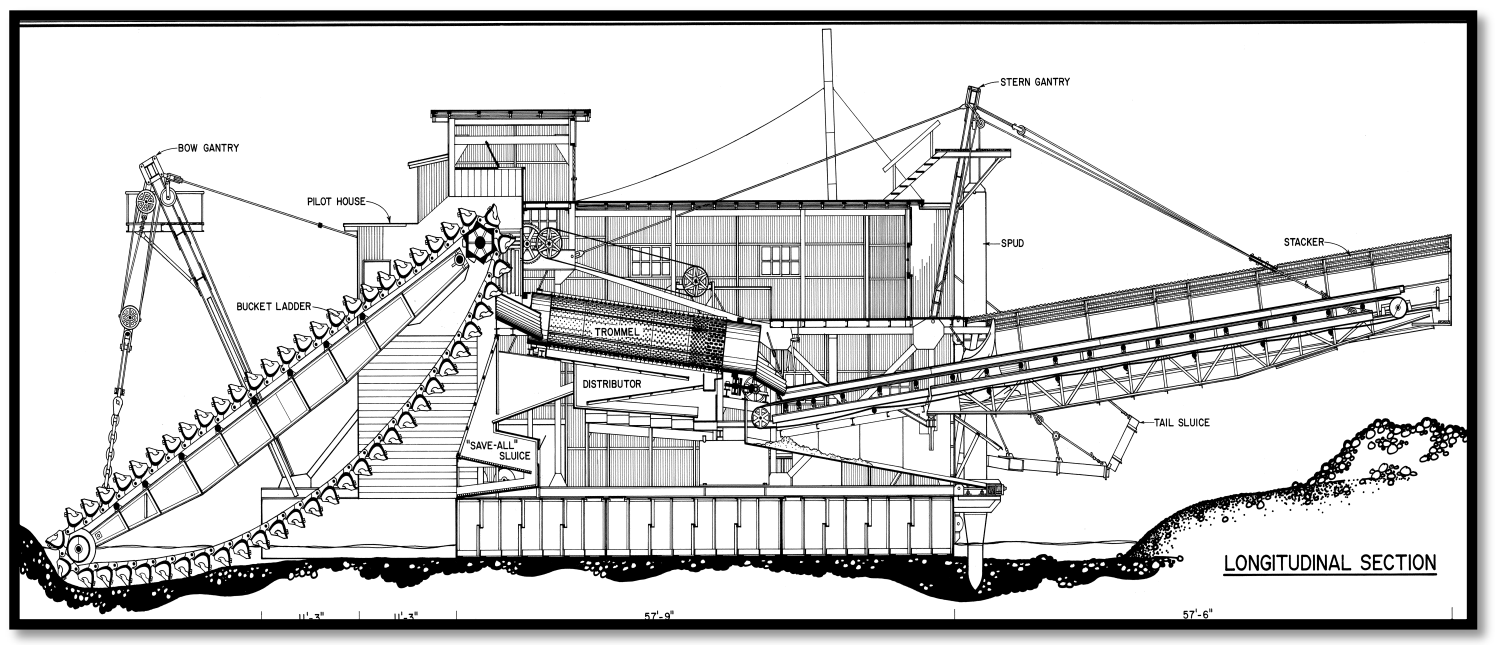

Figure 3.13: Profile of dredge (Courtesy Library of Congress, Historic American Engineering Record, AK,19-EGL.V,4A)

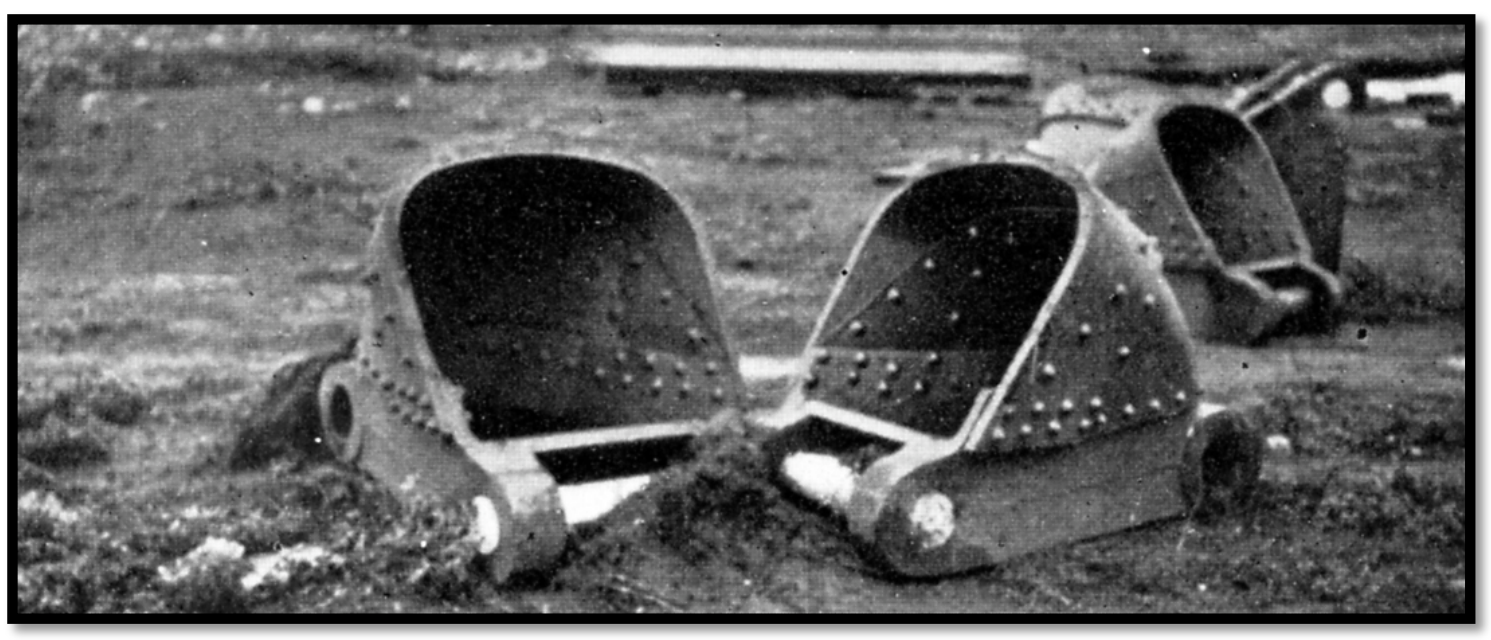

Figure 3.14: Cast iron dredge buckets (Purington 1905:Plate XXXII)

The buckets carry material up the elevator and dump it into a chute, which sends the material into classifying trommels. Trommels are revolving screens that sort the material by size by rotating along their longitudinal axis. As they

${ }^{47}$ Peele, Mining Engineers' Handbook, 930. 
rotate, water is introduced to the alluvium within the trommel, which helps break down the material. The smaller material passes through the openings in the screen and is sent to a sluice, while the larger material is discarded. The tailings from the sluice and trommel are sent out the rear of the machine by another conveyor and stacked in the previously worked area. ${ }^{48}$ The bucket dredge is secured by a system of guy lines attached to a mast located at the rear of the ship. Additionally, a digging spud acts as an anchor that the dredge pivots on as the guy lines are winched. The bucket line dredge starts digging at the surface of the deposit and continually drops until it reaches bedrock. Once the dredge hits bedrock, it releases its spud and moves forward continuing to dig through the auriferous deposit. ${ }^{49}$

The type of placer often dictated the tools and techniques that miners chose to exploit these deposits. Miners in the Fairbanks district found both shallow low-grade deposits and deep high-grade deposits, deposits that miners worked with different methods. The shallow placers were exploited with open-cut mining techniques, processes that exposed the largest amount of bedrock in the shortest amount of time, allowing for expedited extraction of the deposit. The deeper placers were subject to drifting, a mining technique focused on handling the smallest amount of valueless material possible, allowing for a greater profit by concentrating more on the auriferous material at bedrock than removing the overburden.

\footnotetext{
${ }^{48}$ Peele, Mining Engineers' Handbook, 932. Peele describes the tailings stacker running for nearly $200 \mathrm{ft}$. past the end of the dredge. The stacker handles the largest material, while the slimes and fine tailings are deposited out of a chute nearly adjacent to the spud.

${ }^{49}$ Cook, Placer Mining in Alaska, 128.
} 
"In Alaska, as a rule, alluvial gold is almost entirely lacking where timber and water are

plentiful, grades are steep, and the ground is unfrozen." Methods and Costs of Gravel and Placer Mining in Alaska, Chester Wells Purington 1905

\section{Chapter 4: Environmental Setting}

This chapter describes the topography, climate, hydrology and vegetation within the Fairbanks mining district. The placer mining techniques of the Fairbanks region were dictated by these local conditions. The lack of precipitation in Fairbanks, created little water with head, which forced miner to construct elaborate systems of ditches to bring water to the mines. The subarctic climate created dense layers of permafrost, ground resistant to drilling and dynamite that forced placer miners to adopt techniques suitable to penetrate the frozen deposit. The climate also affected the transportation systems in the district, producing conditions favorable for overland winter transport and prohibitive for overland summer travel. Dense stands of spruce were lacking near the placer fields; spruce was used as construction materials for structures, material for roadbeds, cribbing for shafts, support for underground drifts and fuel for the boilers, and due to its finite nature, miners were forced to adapt to the dwindling resource. This chapter provides an overview of the natural setting of the Fairbanks Mining District, focusing on the interplay between culture and the environment and how the two shape the decision making practice.

\section{Topography}

The Fairbanks Mining District is located in the Yukon-Tanana Uplands, a geographic region in central Alaska. The Yukon-Tanana Uplands are located 
between the Tanana River and the Yukon River (see Figure 4.1). South of the Yukon-Tanana Uplands are the Tanana Lowlands, and the Yukon Lowlands are located to the north. Small ridges characterize the Yukon-Tanana Uplands, averaging an elevation between 2,000-3,500 feet. The ridgeline patterns follow a northeast-southwest trend and are interspersed with prominent landscape features, referred to locally as domes. Domes rise from a few hundred to over a thousand feet above the ridgeline and are characterized by generally flat tops and gently sloping sides. " "V" shaped valleys undulate between the ridgelines and drop in elevation up to 2,000 feet below the tops of the ridges. ${ }^{2}$

The topographic conditions in the Fairbanks district were far from favorable for the placer miner; they were in fact, "inimical" (Purington 1905) to his success. ${ }^{3}$ However, the moderate topography of the district allowed for comparatively inexpensive construction of roadways, in contrast to those built in more rugged areas of Alaska. The subtle contours of the region provided little water with head, forcing some miners to construct expensive systems of ditches to bring water with head to the mines.

\footnotetext{
${ }^{1}$ James Hill, "Lode Deposits of the Fairbanks District, Alaska”, USGS Survey Bulletin 849-B (Washington: GPO, 1933) 35.

${ }^{2}$ L.M. Prindle and F.J. Katz, "A Geologic Reconnaissance of the Fairbanks Quadrangle, Alaska”, USGS Bulletin 525 (Washington: GPO, 1913) 20.

${ }^{3}$ Chester Wells Purington, "Methods and Costs of Gravel and Placer Mining in Alaska", USGS Bulletin No. 263 (Washington: GPO, 1905) 31.
} 


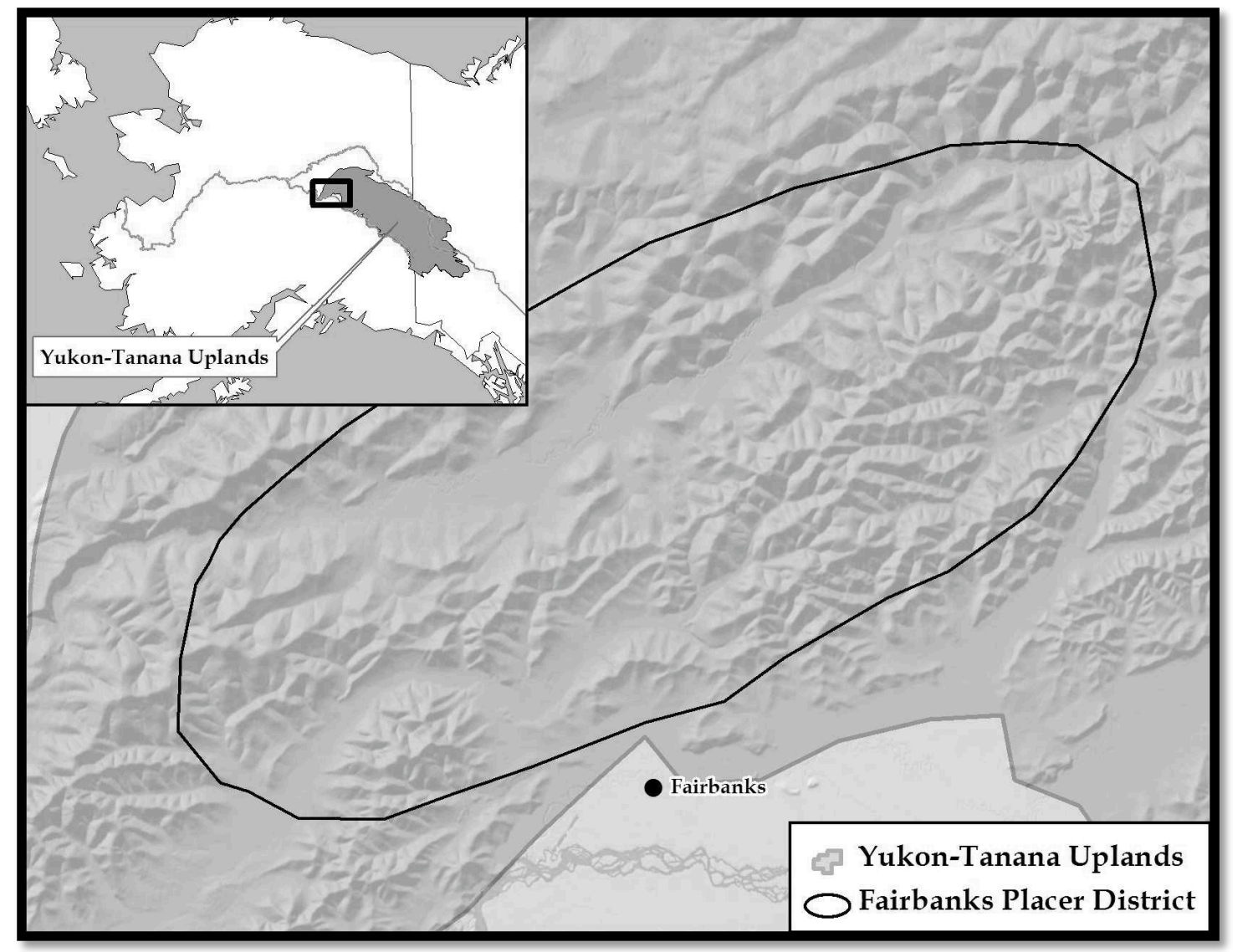

Figure 4.1: Map showing the location of the Yukon-Tanana Uplands (Baeten: 2012)

\section{Climate}

The climate in the Fairbanks Mining District played as crucial a role in the techniques and technologies employed by placer miners as the deposits themselves. Typical of regions located at high latitudes and far from coastal zones, the climate of the Fairbanks Mining District is arid and subarctic. Average precipitation in the Fairbanks region from 1904-1929 was a mere 11.45 inches per year. ${ }^{4}$ The majority of precipitation came sporadically in the summer, occurring in rainfalls of less than a half of an inch. ${ }^{5}$ Winter snowfall

\footnotetext{
${ }^{4}$ Hill, Lode Deposits of the Fairbanks District, Alaska, 36.

${ }^{5}$ Prindle and Katz, A Geologic Reconnaissance of the Fairbanks Quadrangle, Alaska, 27.
} 
was also sporadic, occurring sometimes as early as August, and as late as May. The average snowfall for the Fairbanks region was roughly 50-70 inches, with the heaviest amount falling in January. ${ }^{6}$ Although the quantity of the snowfall was not excessive it provided additional waterpower during the summer months.

The Fairbanks area also owes its temperature to its high latitude and elevation. The Fairbanks region can see a temperature range of over 150 degrees in a year. During the summer months the temperature can reach nearly 100 degrees, and during the winter it can fall to 60 degrees below zero. ${ }^{7}$ The extreme cold of the winter was an obvious detriment to the miner's quality of life, but it also facilitated winter mining. The subarctic climate led to the formation of permafrost, freezing the alluvium as deep as 300 feet (see Figure 4.2). The permafrost acted as a support system for underground mining, essentially creating an underground hard-rock mining environment within a placer deposit. The permafrost alleviated much of the overhead cost required for placer drift mining in other locales, which required an extensive underground timber support infrastructure. The permafrost solidified and stabilized the alluvium, making extensive timbering of the drifts unnecessary.

\footnotetext{
${ }^{6}$ This statistic differs from the above-mentioned average of annual precipitation, due to the composition of snow. The Natural Resource Conservation Service of the USDA provides a Snow Water Equivalent (SWE) measurement. The SWE factors snow depth multiplied by snow density. Due to the extremely cold winter months in Fairbanks, the density of the snow is quite low. This creates a fairly low SWE. January may produce 10 inches of snow, but the resulting SWE is less than an inch. See :<http://www.or.nrcs.usda.gov/Snow/about/swe.html>.

${ }^{7}$ Hill, Lode Deposits of the Fairbanks District, Alaska, 36.
} 


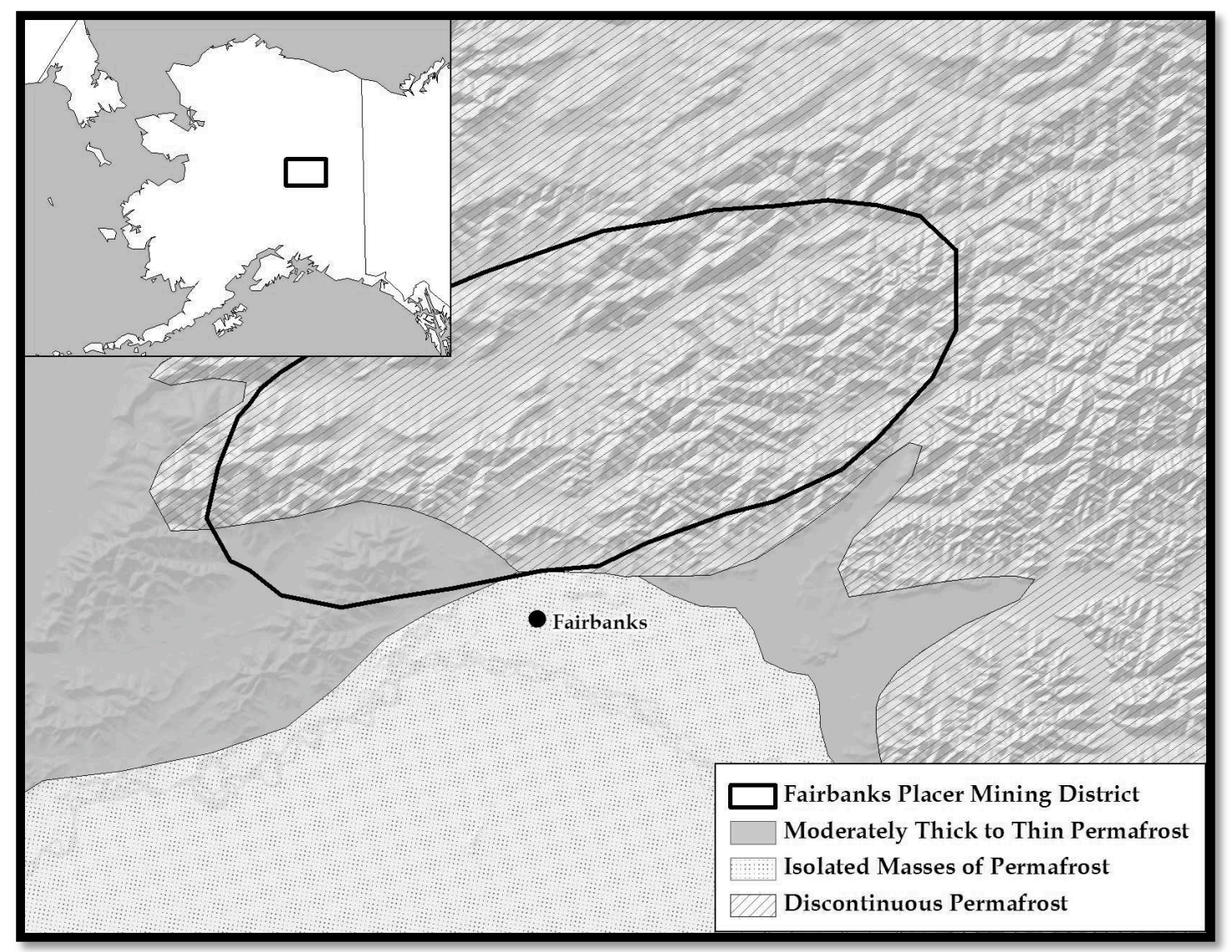

Figure 4.2: Distribution of Permafrost in the Fairbanks Region (Baeten: 2012)

In some ways, the subarctic climate facilitated overland winter transportation. The overland winter transportation routes relied on snowfall, to provide a good surface for dog sled or horse-drawn sleigh. If the snow cover was too light, the trails became prohibitive for winter travel to the mines. The subarctic environment also affected summer transportation. Most heavy supplies entered the Fairbanks region via sternwheeler or steamer from St. Michael or Dawson. Water transportation had a limited season due to ice buildup from late September until early May, when the "break-up" occurred. ${ }^{8}$ The subarctic climate also discouraged summer transportation due to the

\footnotetext{
${ }^{8}$ Prindle and Katz, A Geologic Reconnaissance of the Fairbanks Quadrangle, Alaska, 24.
} 
composition of the ground cover of moss, which insulated the permafrost. Once this layer of moss is cut, thawing could commence. Road construction in these conditions was costly.

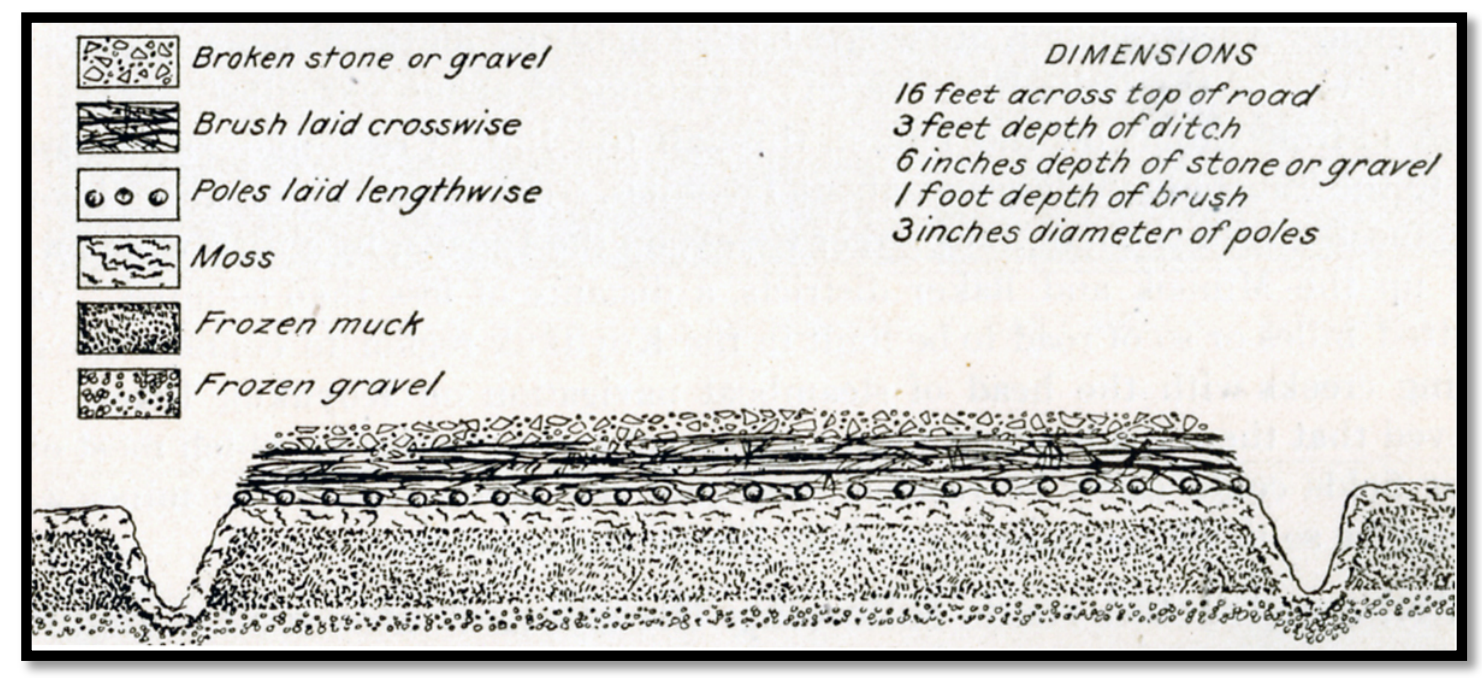

Figure 4.3: Road Construction Technique in the Klondike (Purington, 1905:225)

Traditionally, trails were developed by frequent travel. In areas with permafrost, this traditional method created a "filthy, slimy, mass of mud, roots and broken stones, a difficult route for men on foot, a slow and tiresome road for loaded animals, and an impassable obstacle to any sort of vehicle" (Purington 1905). ${ }^{9}$ To compensate for the composition of the ground, roadbuilders in Fairbanks region developed a method building-up of the roadbed with layers of various material (see Figure 4.3). The method of constructing roads in the Fairbanks district drew upon similar practices used in the Klondike. These techniques were initially expensive, but the practice increased the roadbed's longevity and led to less frequent repair and maintenance costs. ${ }^{10}$

\footnotetext{
${ }^{9}$ Purington, Methods and Costs of Gravel and Placer Mining in Alaska, 219.

${ }^{10}$ Purington, Methods and Costs of Gravel and Placer Mining in Alaska, 225.
} 


\section{Hydrology}

The streams within the Yukon-Tanana Uplands are generally uniform in their grade, quantity of water and layout, owing to the relatively moderate topography. The main placer producing, or paying, drainages of the District: Cleary, Pedro and Fairbanks are all relatively short (less than 10 miles in length), carry little water and have subtle grades. ${ }^{11}$ The drainages meander over shallow grades, consistently braiding along their path, expelling their overflow into side tributaries dissecting the ridges. As the streams run their generally level course they gradually lose what little head they had. This continual loss of head creates unfavorable conditions for the placer miner and eliminates the possibility of full-scale hydraulic mining. In addition to the lack of head, the semi-arid conditions hindered placer mining. From 1908-1920, numerous reports are published decrying the shortage of water for mining purposes, including the eventual full shutdown of mining operations in the Fairbanks district in $1910 .^{12}$

Water plays an essential role in placer mining; it is used for excavation, transportation, and processing of the alluvium. This process, specifically excavation, is expedited if the available water has sufficient head. Due to the lack of head, miners in the Fairbanks district created linear systems of ditches, used to carry water from a drainage to a mine site (see Figure 4.4). During its course, the ditch runs at a grade suitable for creating enough head in the water for mining purposes. The construction of ditches was originally undertaken by small groups of miners, starting in 1904. By 1905 about 3 miles of ditches were in use in the Fairbanks district, dropping in grade by about 2 feet-per-mile. ${ }^{13}$ As

\footnotetext{
${ }^{11}$ Alfred Brooks, "Alaska", The Engineering and Mining Journal, Vol. LXXIX (01-05-1905) 16-18.

12 "Mining News", The Engineering and Mining Journal Vol. XC (09-17-1910) 574. Also see Vol. $\mathrm{XCI}, \mathrm{XCIII}$, and XCV.

${ }^{13}$ Purington, Methods and Costs of Gravel and Placer Mining in Alaska, 105.
} 
the district developed, ditch building companies were incorporated to pursue grand undertakings, ending with the construction of the roughly 90 mile long Davidson Ditch in $1925 .{ }^{14}$ The Davidson Ditch was designed by professional engineers and maintained by full time ditch tenders.

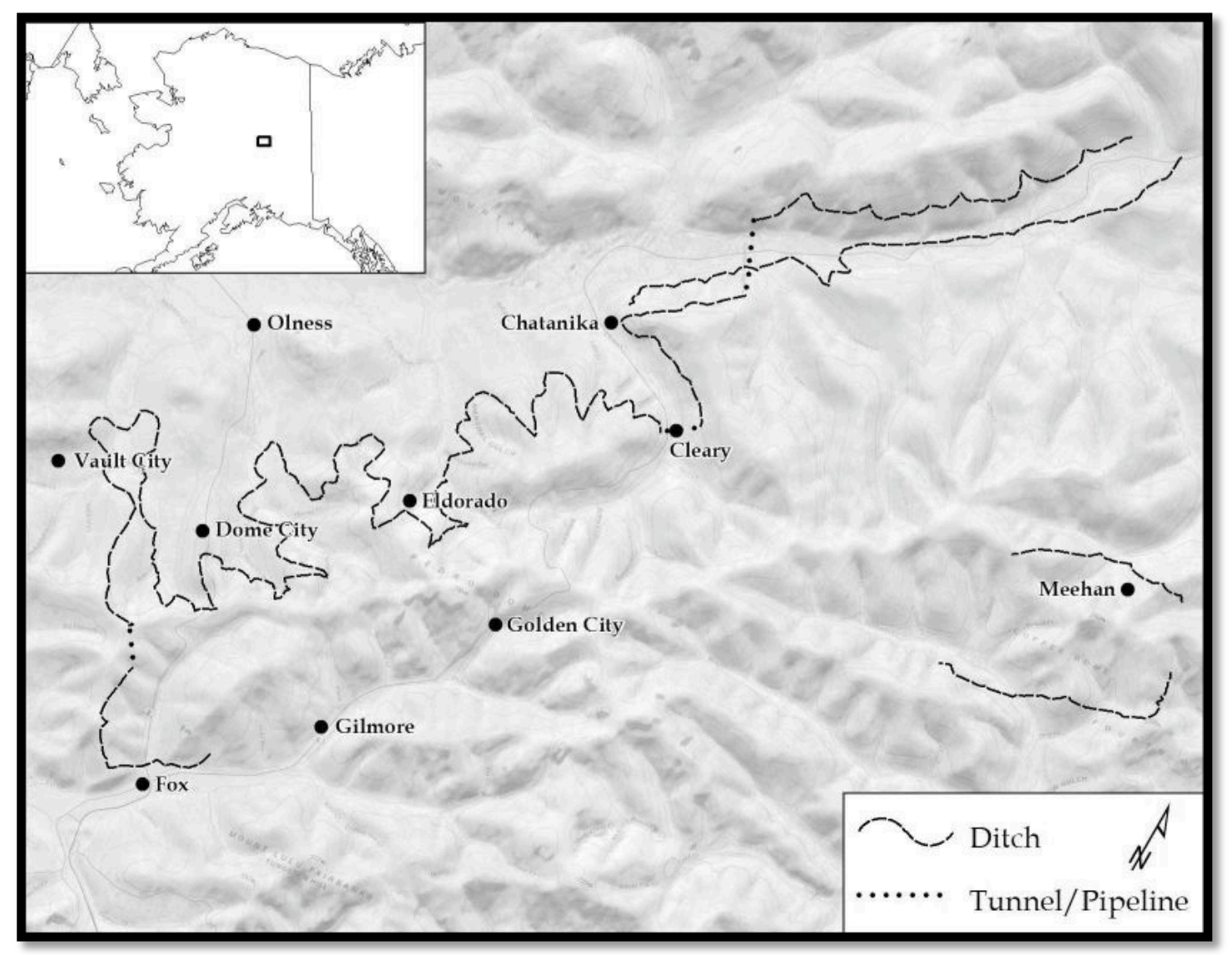

Figure 4.4: Overview of Ditches in the Fairbanks District (Baeten: 2012 - Digitized Map by Prindle, Katz \& Hill, 1933)

\footnotetext{
${ }^{14}$ Catherine M. Williams, Joshua D. Reuther and Peter M. Bowers, History of the Davidson Ditch, North of Fairbanks, Alaska (Unpublished report prepared for Fairbanks Gold Mining, Inc., 2003) 9-17.
} 


\section{Vegetation}

The altitude of the region defines the density and distribution of vegetation in the Fairbanks Mining District. Generally speaking, the lower the altitude, the denser and more diverse the vegetation. Residents of the Fairbanks region utilized the local vegetation in a number of ways; berries were consumed for nourishment, dwarf birch for heat and cabin insulation, and moss, the utilitarian species of the understory, used for roofing and chinking of cabin walls, repair material for leaking ditches and a filter for water added to boilers. ${ }^{15}$ The most important species for mining was the spruce tree. The spruce tree was the primary material used for shelter, fuel for boilers, construction materials for above-ground mining equipment, stabilization for underground drifts, corduroy for wagon trails and ties for railroads. Spruce thrives at lower altitudes and is rarely found large enough for mining purposes at elevations over 2500 feet (see Figure 4.5). ${ }^{16}$

\footnotetext{
${ }^{15}$ Prindle and Katz, A Geologic Reconnaissance of the Fairbanks Quadrangle, Alaska, 28.

${ }^{16}$ Prindle and Katz, A Geologic Reconnaissance of the Fairbanks Quadrangle, Alaska, 28.
} 


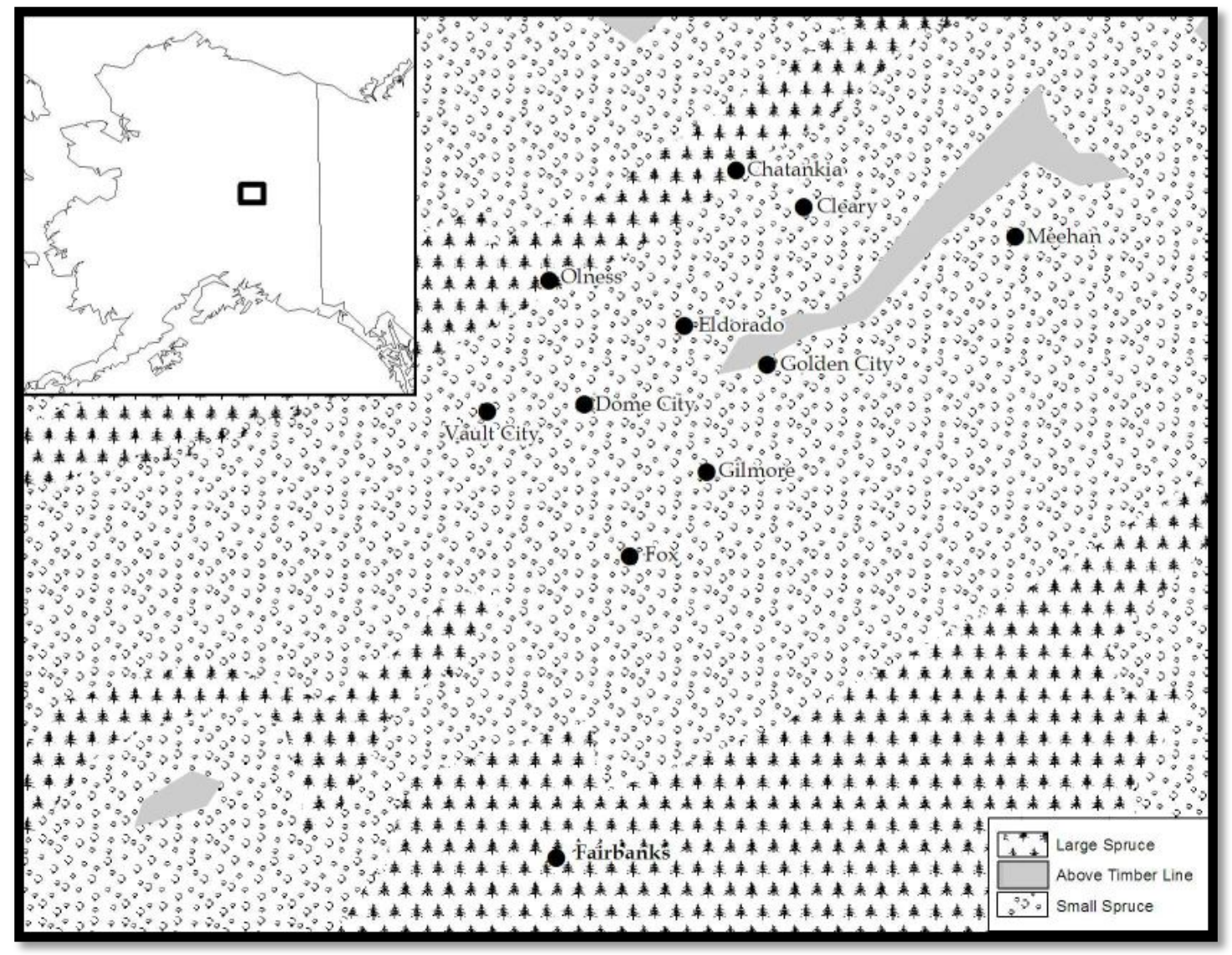

Figure 4.5: Distribution of Timber in the Fairbanks District in 1908 (Baeten: 2012 - Digitized Map by Prindle \& Kať, 1908)

The Fairbanks Mining District, and the entire Yukon-Tanana Uplands, produces very little timber suitable for mining purposes, with the majority of large spruce stands found in the outside of the district in the adjacent southern Tanana Lowlands. Adequate timber for mining purposes was located solely in the valleys often near the placer mines themselves. The local sources of timber were quickly exhausted as the mines developed, with some mines using up to a cord of wood per-day to fuel their boilers. ${ }^{17}$ By 1908, nearly all of the timber supply of the Fairbanks Mining District was depleted, forcing miners to seek

\footnotetext{
${ }^{17}$ Alfred Brooks, Report on Progress of Investigations of Mineral Resources of Alaska in 1904, USGS Bulletin No. 259 (Washington: GPO, 1905) 27.
} 
elsewhere for mining timbers, beginning with the Tanana Lowlands and eventually farther coastal zones. ${ }^{18}$ The rapid deforestation of the district from the development of the mines ultimately increased the cost of fuel for mining by as much as three times. ${ }^{19}$ By 1914 , standing timbers in the district were completely exhausted and miners actively dug stumps to fuel their boilers. Coal was introduced to the region in the 1920s with the completion of the Alaska Railroad, allowing for the native spruce to grow and repopulate the YukonTanana Uplands.

\footnotetext{
${ }^{18}$ Norman L. Wimmler, "Placer Mining Methods and Costs in Alaska", Bureau of Mines Bulletin No. 259 (Washington:GPO, 1927) 28.

${ }^{19}$ Alfred Brooks, "Mineral Resources of Alaska, 1916", USGS Bulletin 262 (Washington: GPO, 1916) 52.
} 
"Fairbanks was never a Cheechako camp. From the outset it was filled with longexperienced, well-toughened miners, with only a sprinkling of greenhorns.”

Pay Dirt, Glenn Chesney Quiett 1971

\section{Chapter 5: Mining Methods and Technologies at}

\section{Fairbanks}

This chapter focuses on the systems of mining employed in the Fairbanks district during its golden years of 1902-1909, when small-scale mining methods prevailed and again in 1927-1959, when large dredges took over as the primary mining technology in the region. This chapter is broken into three parts: drift mining, open-cut mining and dredging. The final section on dredging differs from the prior two as it focuses on the economic impacts of dredging in the Fairbanks region and the individual businesses responsible for the widespread development and use of this technique.

\section{Drift Mining}

\section{The Technique}

Drift mining is a technique used to extract gold bearing alluvium within deep placers. Drift mining entails sinking a shaft to bedrock and running perpendicular drifts from the shaft along the paystreak. The depth of the paystreak within the placer deposits in the Fairbanks Mining District shaped the regions' early mining history, forcing miners to adapt the system of drift mining used in the Klondike to local conditions. Extracting within the drifts is generally organized in a manner similar to the longwall retreating method used in underground coal mining. Using the longwall retreating method, miners first extract material from the farthest reaches of the drift and then work back towards the shaft in a broader pattern. Miners in the Fairbanks district employed drift 
mining extensively, reaching proportions that trumped those seen in California drift mining. ${ }^{1}$ By $1908,85 \%$ of the 300 placer mining operations in the Fairbanks district were engaged in drift mining. ${ }^{2}$ Although the technique was nearly abandoned by the 1920s, due to the depletion of the valuable deep placers and introduction of dredges, the development of drift mining in the region defined early placer mining in Alaska's interior.

\section{The Process: Prospecting, Development, Sluicing, Winter Mining}

Drift mining can be separated into winter mining and summer mining. Winter mining is principally extractive, focusing on underground development and the removal of auriferous material. The gravels extracted during the winter months are hoisted from the shafts and dumped onto large conical piles called winter dumps. Winter dumps (see Figure 5.1) are continually built up until thawing commences and water begins to flow in the adjacent ditches.

\footnotetext{
${ }^{1}$ Genevieve Parker, The Evolution of Placer Mining Methods in Alaska (Unpublished Thesis: Alaska Agricultural College and School of Mines, 1929) 31.

${ }^{2}$ L.M. Prindle \& F. Katz, A Geologic Reconnaissance of the Fairbanks Quadrangle Alaska, USGS Bulletin 525 (Washington: GPO, 1913) 115-116.
} 


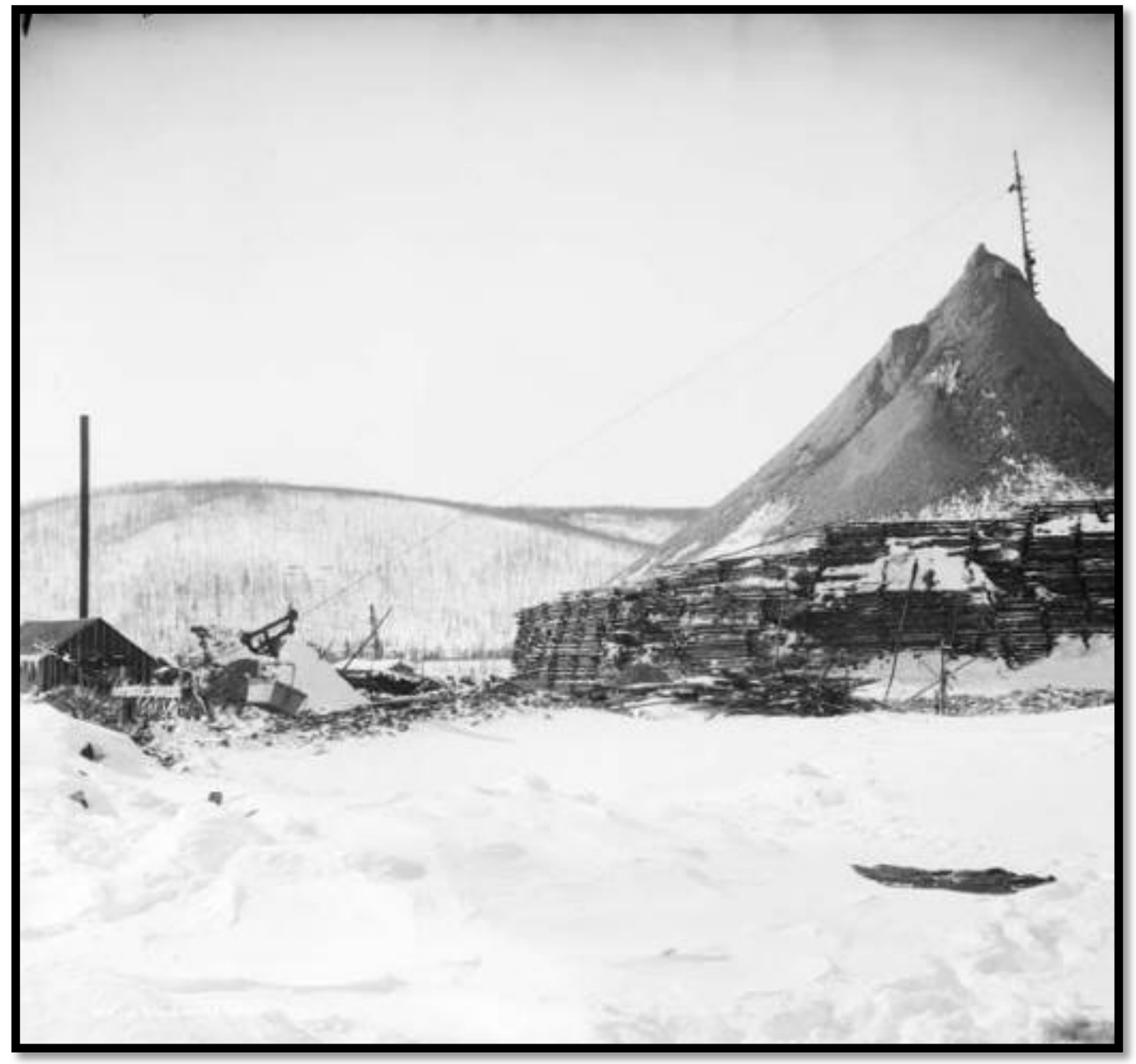

Figure 5.1: Winter dump in the Fairbanks district (Courtesy of University of Alaska Fairbanks, Alaska and Polar Regions Collection, Albert Johnson Collection, Accession \#UAF-1989-166-634)

Once present, the water is used to thaw the still frozen auriferous material in the dumps as well as wash it over sluice boxes that are built into the dumps, eliminating the need for additional transport. The water from the ditches also transports the waste matter, or debris, away from the mine through flumes. ${ }^{3}$ Winter mining is less cost intensive than summer mining; the underground

\footnotetext{
${ }^{3}$ Prindle \& Katz, A Geologic Reconnaissance of the Fairbanks Quadrangle Alaska, 129.
} 
development work generally required no timbering and winter wages were roughly half that of summer pay. ${ }^{4}$

Summer mining also includes surface and subsurface development, extracting and washing the alluvium. The subsurface development undertaken during the summer in drift mining required constructing a timbered infrastructure even though the deposits being mined were within the permafrost. This underground infrastructure was constructed to counter the introduction of warm summer air that could cause slumping and subsidence of the underground workings. This chapter will focus on the summer mining process and equipment used to develop, extract and wash auriferous material ${ }^{5}$.

\section{Prospecting \& Exploration}

Prospecting is the initial process used while searching for profitable ground. After staking a claim, placer miners needed to prospect the area in order to find locations with favorable auriferous material prior to full-scale development. Prospecting is undertaken through a variety of methods using both inexpensive techniques, like pick and pan, and more technologically advanced equipment, like the churn drill. The objective of prospectors in the Fairbanks District was digging through the valueless overburden until hitting bedrock. In the Fairbanks district, prospecting can require excessive time and expensive equipment due to the extreme depth of the deposits. Equipment used for prospecting included material for: extraction, (like pick and shovel), hoisting (a hand windlass) and testing (a gold pan).

In the Fairbanks district additional steps were required in sinking the prospect due to the frozen state of the alluvium. Early miners in the Fairbanks

\footnotetext{
${ }^{4}$ Chester Wells Purington, Methods and Costs of Gravel and Placer Mining in Alaska, USGS Bulletin 263 (Washington: GPO, 1905) 82.

${ }^{5}$ Summer mining methods involve the same techniques used in winter mining, with the addition of washing the alluvium stockpiles. Attention is paid to summer mining for this reason.
} 
district relied on thawing techniques used in the Klondike, including, fires, heated rocks, and buckets of hot water. ${ }^{6}$ However, steam-thawing equipment reached the area relatively quickly and aided the miners in thawing the deep frozen deposits. Steam became the primary thawing agent employed in the placer fields of the arctic, generated through a system of portable boilers and steam points, hoses and pipes. This thawing equipment will be described in further detail below.

The common prospecting technique used by early Fairbanks miners incorporated prospect pits rather than mechanized core sampling churn drills, which appeared at a much later date in the area. ${ }^{7}$ The paystreak's depth made the cost of prospecting extremely high, as miners sometimes had to extract up to 300 feet of overburden just to reach the auriferous material. The frozen state of the alluvium added additional costs to the prospecting process, with miners spending an exorbitant amount of money and time fueling the boilers to thaw the recalcitrant muck prior to hitting paydirt (see Figure 5.2).

\footnotetext{
${ }^{6}$ Prindle \& Katz, A Geologic Reconnaissance of the Fairbanks Quadrangle Alaska, 116-117.

${ }^{7}$ Hubert Ingersoll Ellis, Mining Methods at Fairbanks (Unpublished Thesis: University of Washington, 1915) 10.
} 


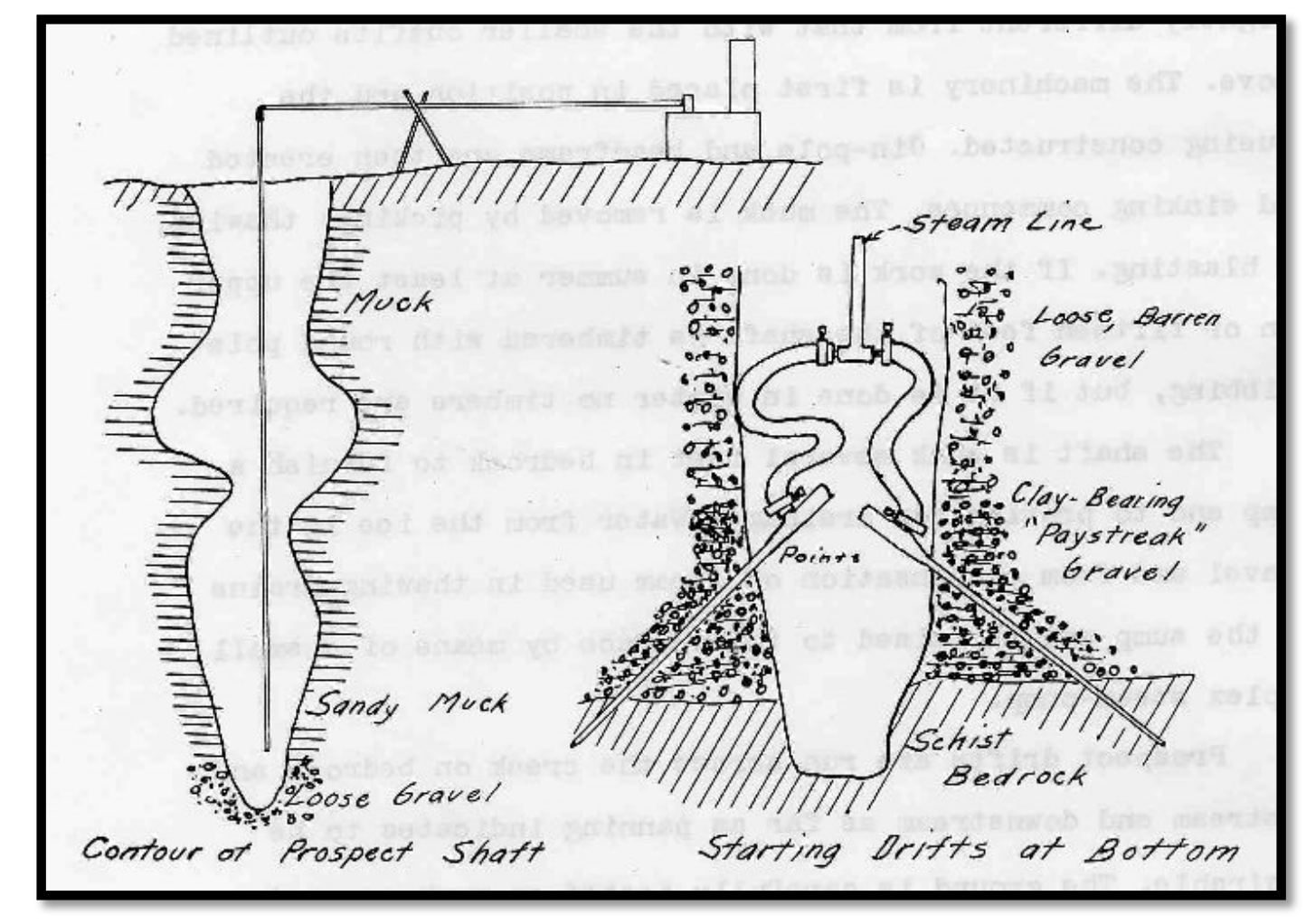

Figure 5.2: Thawing a prospect pit (Ellis 1915:10)

Once the prospect pit or shaft is sunk, miners panned samples of the alluvium found near the bedrock. If the samples prove to be promising, development of the area ensued; if the prospect yielded poor results, more prospects were sunk within the claim area. Sinking a test pit 300-feet to bedrock with the possibility of locating an unprofitable paystreak was a costly risk for miners in the Fairbanks district. Most regions in Alaska averaged around 20 prospects per claim, but due to its deep placers, miners in the Fairbanks district routinely sunk an average of only four prospects per claim. ${ }^{8}$ The lack of prospecting and the selective sampling of only the most valuable alluvium located at bedrock led to the initial failure of many mines. Selective sampling entailed miners testing only the auriferous material located near bedrock, giving them

\footnotetext{
${ }^{8}$ Purington, Methods and Costs of Gravel and Placer Mining in Alaska, 40.
} 
results with promising, high returns. In doing so, many miners forgot or failed to account for the additional material and cost needed to fully develop a mine.

\section{Development}

Once a favorable paystreak was located, the full-scale development of the area could commence. Unlike prospecting, where miners haphazardly thawed and excavated the pit as quickly as possible, the sinking of shafts required patience to ensure they retained stability during their operation. Shafts in Fairbanks are sunk, or "squared-up", through a technique that relied on steam points that are driven into the center and the four corners of the prospective shaft, thawing the muck, which is loosened out with a pick. ${ }^{9}$ The dimensions of the shafts vary, but most measure between 6-7 feet square. On average, shafts can be sunk at a pace of 5-8 vertical feet per day, during a two-man shift. ${ }^{10}$ At this pace, the shaft was sunk to bedrock and then into it, creating a void at the bottom of the shaft. This void at the bottom of the shaft acted as a sump, to provide drainage within the mine and permitted the hoisting bucket to sit flush with the ground level of the adjacent drifts, allowing for easier dumping from the tramline.

Shafts used primarily for winter mining are rarely cribbed extensively, since the permafrost within the shaft adequately retains the shape and dimensions of the shaft. If the shaft will be used during the summer, or if it will function for more than one season, framing the shaft with timbers is necessary. Lining the shaft with timbers supports the structural integrity of the shaft, preventing it from slumping while the exposed permafrost thaws in the summer heat. Cribbing in the Fairbanks district consists of lining the shaft horizontally with spruce poles between three inches and eight inches in diameter. Moss and

\footnotetext{
${ }^{9}$ Ellis, Mining Methods at Fairbanks, 18.

${ }^{10}$ Norman L. Wimmler, Placer-Mining Methods and Costs in Alaska, USGS Bulletin 259 (Washington: GPO, 1927) 115.
} 
gravel are used as chinking in the shaft, filling the spaces left in between pieces of the cribbing. The most important cribbing are located at the top end of the shaft, called the collar, and near its bottom end, called the station. At the station the cribbing is made in a square-set arrangement (see Figure 5.3).

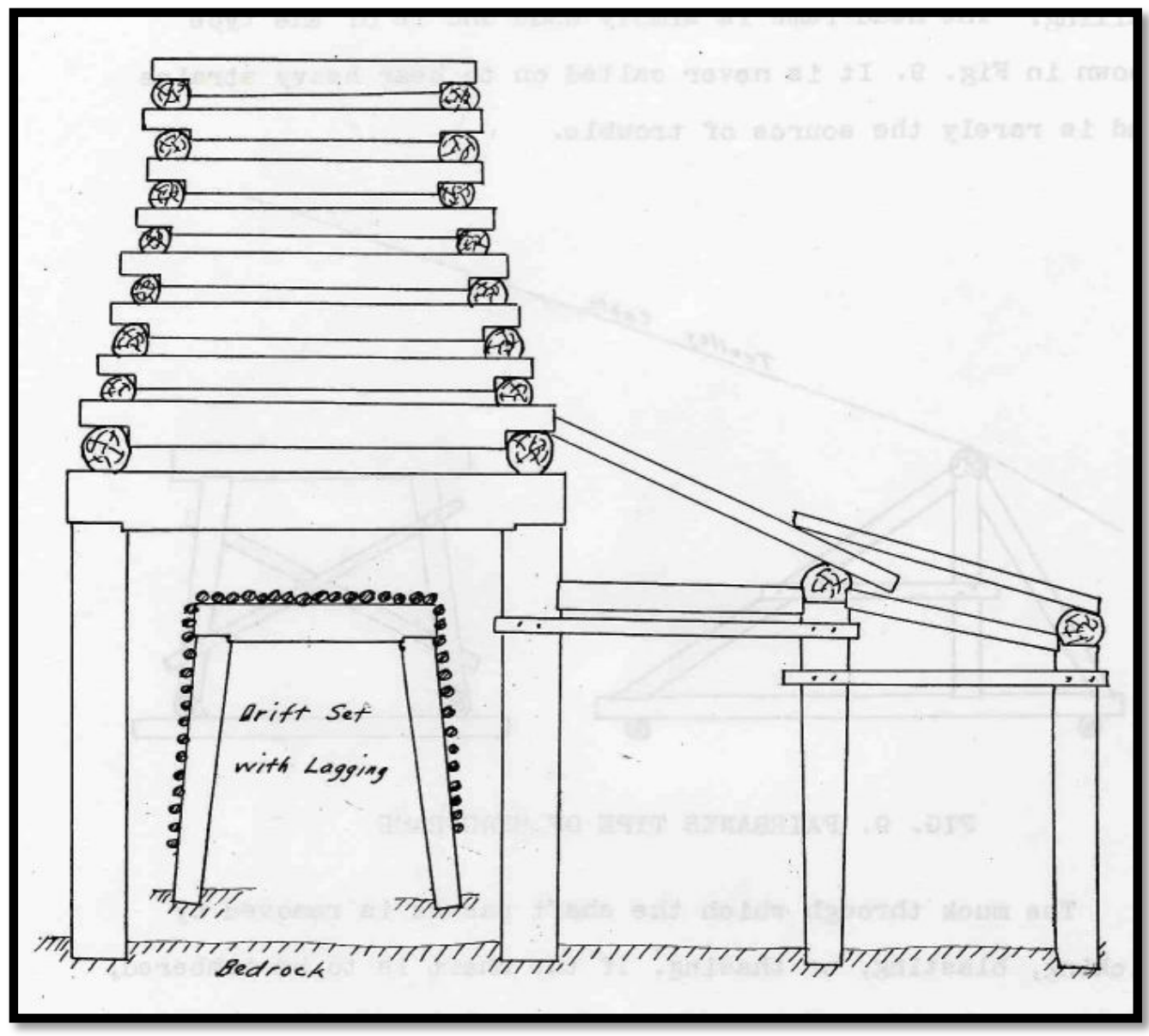

Figure 5.3: Square set cribbing (Ellis 1915:19)

The square-set is composed of larger timbers, up to 20 inches in diameter that are placed vertically at the four corners of the shaft. These vertical timbers are braced with equally large timbers running horizontally across their tops. A square-set assists the ancillary drift portals in retaining their shape where they intersect the shaft. At the surface, the shaft's collar is built up above the ground, typically 1-2 courses higher than the surface. The summer heat causes the 
permafrost to retract. Due to wear and tear from use, the collar and adjoining top cribbing need to be replaced or added to frequently in order to retain the portal's integrity.

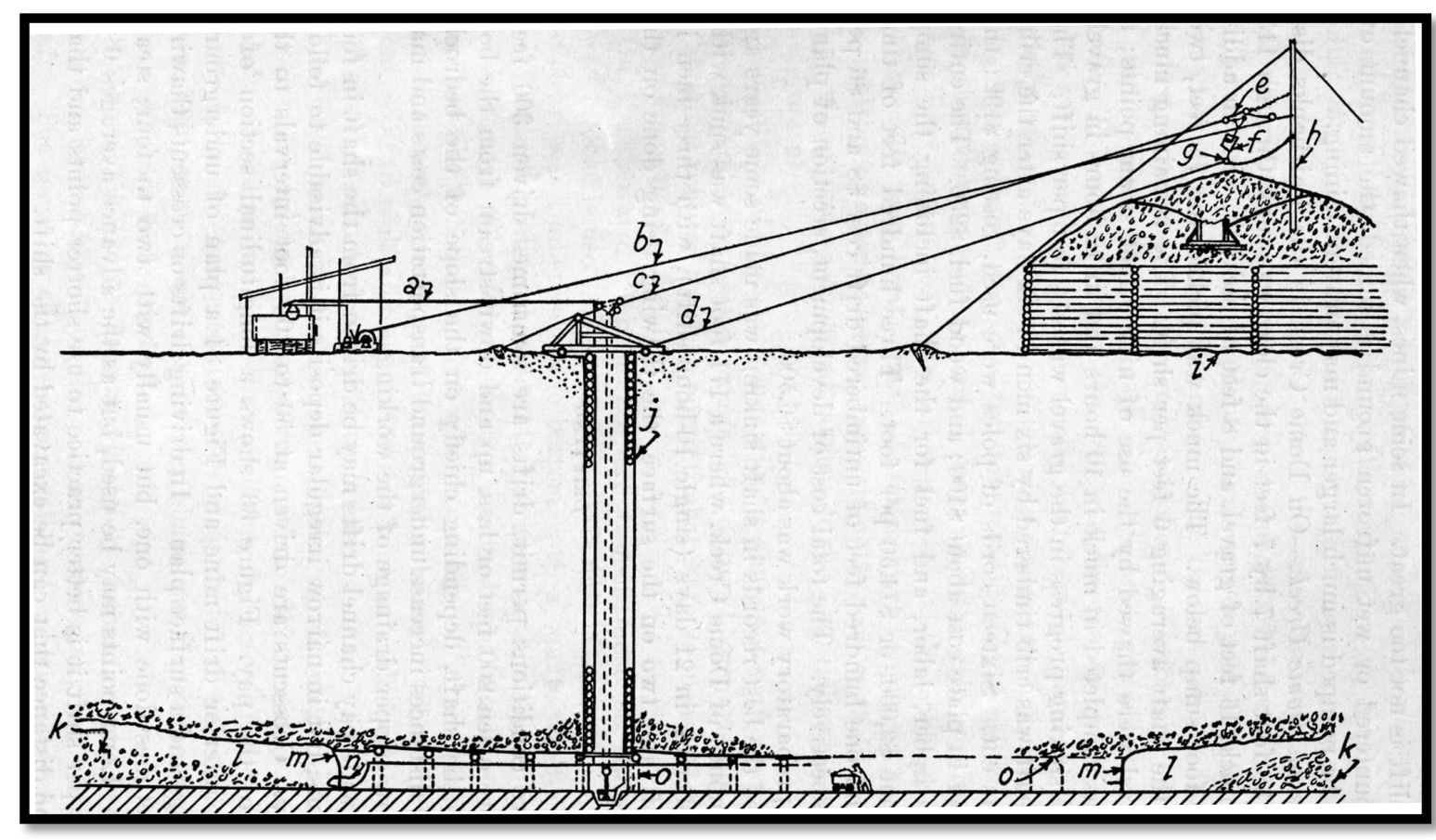

Figure 5.4: Cross section of drift mine, note sluice within dump (Wimmler 1927:118)

Running horizontally from the shaft station is the main drift, or gangway, that acts as the primary conduit for the transportation of paydirt (see Figure 5.4). The gangway, which measures roughly 6 feet $x 6$ feet, runs off of the timbered square-set, and is heavily timbered with 8-inch diameter, 6 foot logs. ${ }^{11}$ If the composition of the gravel tends to be loose, the entire gangway is framed with small spruce poles; if it is solid it is left unframed. ${ }^{12}$ The gangway runs the entire length of the proposed working area, as much as 200 feet from the shaft. Excavation of the gangway occurs in a similar manner as the shaft, but working horizontally, with steam points thawing and picks dislodging the gravels. In 1905,

\footnotetext{
${ }^{11}$ Purington, Methods and Costs of Gravel and Placer Mining in Alaska, 83.

${ }^{12}$ Prindle \& Katz, A Geologic Reconnaissance of the Fairbanks Quadrangle Alaska, 122.
} 
the development of a tunnel cost $\$ 6.25$ per foot, including thawing, excavating, timbering, laying track and tramming, or moving the paydirt from the point of excavation to the shaft's station for hoisting. ${ }^{13}$

Running transversely off of the gangway are linear excavations known as drifts (see Figure 5.5). Drifts occur at intervals of about 50 to 100 feet along the gangway. ${ }^{14}$ Drifts, like the gangway and shaft, also need to be thawed in their development. Drifts are generally subject to less stabilizing infrastructure than the gangway, as miners were only concerned with extraction within the drift. Drifts run to the end of the paystreak, up to 300 feet in length from the main tunnel, and are excavated in a retreating method back towards the main tunnel. The retreating method involves the excavation, or stoping, of the drifts at points located farthest from the shaft first. The active stoping areas are supported by unthawed pillars of gravel or are occasionally timbered. The miners excavate the face of the drift, generally focusing on the 4-5 feet above bedrock and about 1-3 feet within the bedrock floor. ${ }^{15}$ Once the area is stoped out, the support system is removed or allowed to cave as the miners continue excavating back towards the main tunnel. The retreating method allowed the miners to excavate one drift while simultaneously thawing and developing another, working their way back to the shaft.

\footnotetext{
${ }^{13}$ Purington, Methods and Costs of Gravel and Placer Mining in Alaska, 84.

${ }^{14}$ Wimmler, Placer-Mining Methods and Costs in Alaska, 117.

${ }^{15}$ Wimmler, Placer-Mining Methods and Costs in Alaska, 119.
} 


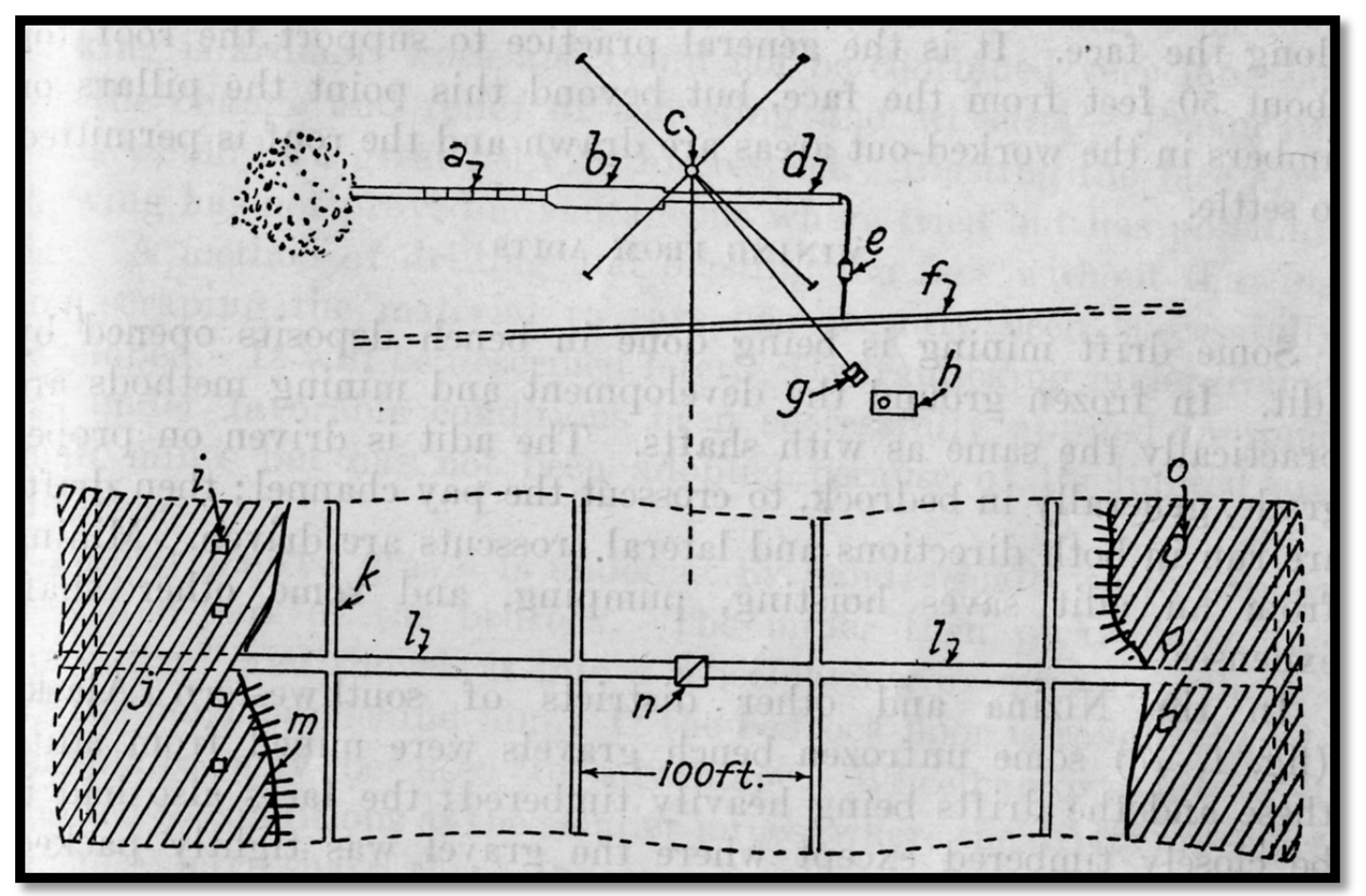

Figure 5.5: Plan view of drift mine (Wimmler 1927:119)

Excavation within the drift involves steam points being driven into the auriferous material just above bedrock and placed at intervals of approximately three-feet. $^{16}$ Thawing and excavating occur at different times, with thawing generally occurring at night and excavation during the day. Steam points, placed within the drift overnight, thaw an average of six-feet depth, three-feet width and four-feet height. ${ }^{17}$ During the thawing process a nominal amount of steam and heat escape from the steam-pipe fittings or from the working face itself. This released heat rises and contacts the roof, which begins to thaw creating loose slabs that can potentially fall into the drift. The slabs continue to form during the thawing process and the waste created from their subsidence is hauled back into the previously worked area. ${ }^{18}$ The escaped heat and steam from the thawing

\footnotetext{
${ }^{16}$ Prindle \& Katz, A Geologic Reconnaissance of the Fairbanks Quadrangle Alaska, 122.

${ }^{17}$ Purington, Methods and Costs of Gravel and Placer Mining in Alaska, 92.

${ }^{18}$ Ellis, Mining Methods at Fairbanks, 28.
} 
apparatus creates sauna-like conditions for the miners, turning the already dim candle-lit drift into a hazardously space filled with fog. The excavation tapers off as the miners retreat back towards the shaft, leaving a sufficient block of frozen gravel supporting the gangway.

As the miners developed their workings, so did they develop their underground transportation network, which evolved from fully manual methods to semi-automated. Traditional transportation involved manually loading a wheelbarrow and pushing it from the drift into the gangway and towards the shaft. Once at the shaft, the wheelbarrow was dumped into a bucket that was hoisted to the surface by windlass powered either by hand or animal. As development in the Fairbanks district increased, underground transportation methods became more sophisticated. With drifts extending over 300 feet from the shaft, the hauling of paydirt with wheelbarrows became exceedingly inefficient. To compensate for this, small-gauge tracks and mine cars were installed on the floor of the gangway. Small, elevated platforms were constructed within the drift, at the intersection of the gangway that effectively allowed miners to dump the contents of the wheelbarrows directly into the mine cars below. The mine cars varied in size, but on average would hold five to six wheelbarrow loads of paydirt, which on average ran equivalent to the full capacity of the hoisting bucket. ${ }^{19}$

The majority of workers in drift mining operations were engaged in underground digging, or at the surface, tending the hoist, dump box and ancillary equipment. The hoisting system at the mine dictated the size of the workforce. If the mine was equipped with a large hoisting system it could process a greater amount of paydirt, leading to an increase in employment of underground miners. Underground workers were divided into teams of 5-6 miners, each of whom was responsible for picking, loading and hauling material (see Figure 5.6).

\footnotetext{
${ }^{19}$ Prindle \& Katz, A Geologic Reconnaissance of the Fairbanks Quadrangle Alaska, 124 (see n. 2).
} 
Underground laborers were paid a flat wage and were expected to process between 75-125 wheelbarrows of paydirt per day. ${ }^{20}$ Assuming that an underground miner was working a drift 200 feet from the shaft and handling 100 wheelbarrows a day, that miner would push his wheelbarrow nearly 10 miles in a given day in addition to excavating the drift. ${ }^{21}$

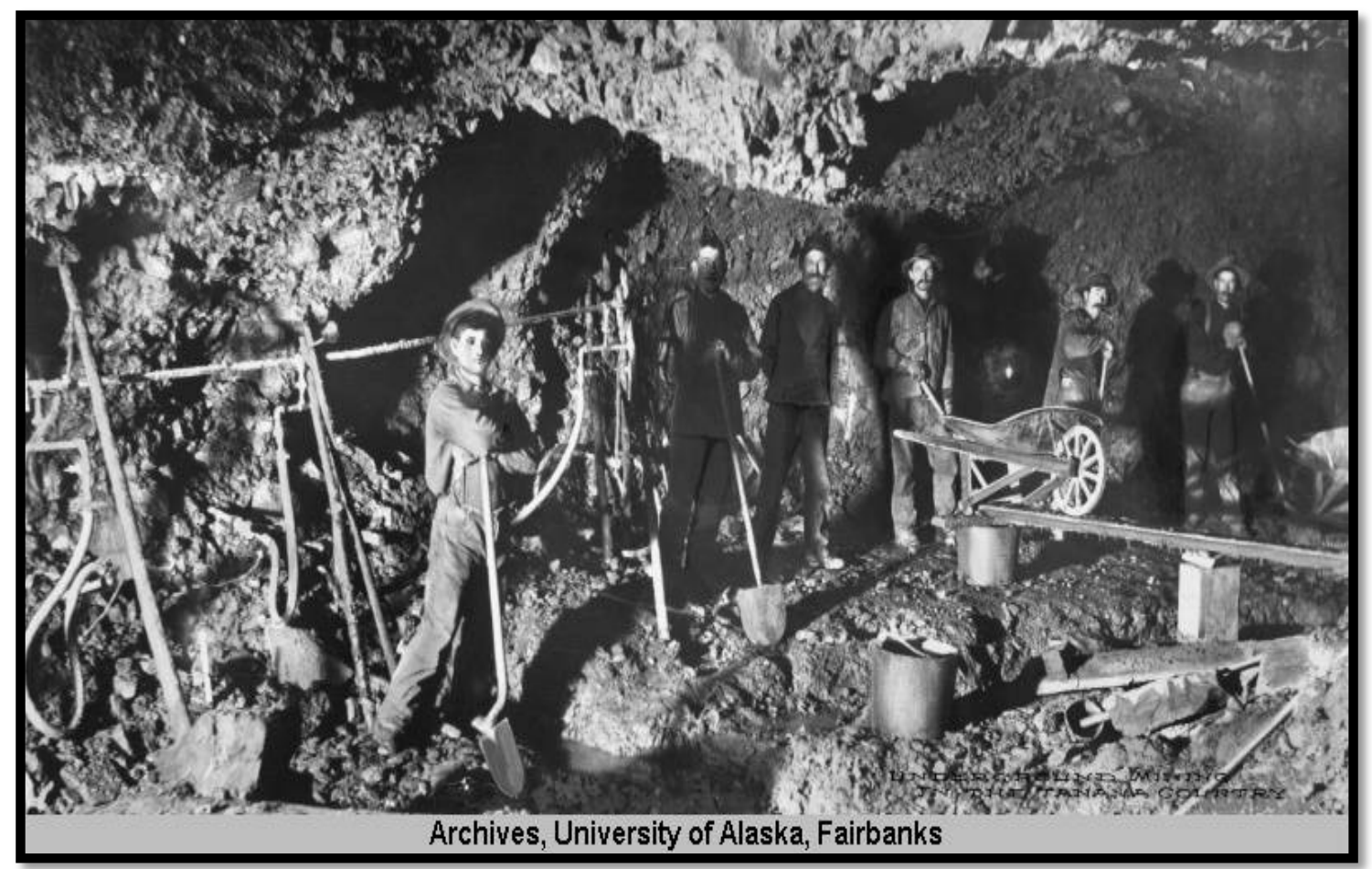

Figure 5.6: Underground drift mining in Fairbanks (Courtesy of University of Alaska Fairbanks, Alaska and Polar Regions Collection, Albert Jobnson Collection, Accession \#UAF-1989-166-30)

During the mining boom years from 1902-1910, miners in the Fairbanks district avidly practiced drift mining. During this time, drift mines employed up to 50 workers underground and excavated up to 200,000 square feet of alluvium in

\footnotetext{
${ }^{20}$ Wimmler, Placer-Mining Methods and Costs in Alaska, 113 (see n. 10). Also see Prindle \& Katz pg. 124, Purington pg. 86-88.

${ }^{21}$ Huber I. Ellis, "Development Methods at Fairbanks", The Engineering \& Mining Journal, Vol.
} 99, No. 24 (06-12-1915) 1028. This workload is obviously less intensive and time consuming with the introduction of small gauge rails and mine cars. 
a season. ${ }^{22}$ At the surface, labor was defined by machinery, as workers were hoist men or dump box tenders. Surface laborers filled skilled professions and were generally paid higher wages than their underground colleagues, as they were responsible for making the operation run smoothly. The hoist operator, along with fueling the boiler, controlled the flow of material into and out of the shaft. Depending on the size of the hoist and the efficiency of the dumping system the hoist system could receive and dump a bucket of paydirt in less than a minute, requiring a proficiently efficient hoist operator. ${ }^{23}$

\section{The Equipment: Boilers, Hoists, Self-Dumping Carriers, Headframes, and Steam Points}

The equipment used for drift mining in the Fairbanks region evolved as the district developed, becoming more advanced as the transportation systems moved from small dirt trails into wagon roads and rail lines. Traditional drift mining equipment needed to be both portable and easy to fix, allowing miners to move the equipment from one prospect to the next, and to repair it themselves with materials found on site. The development of roads, rails and businesses in the area increased the availability of larger and more efficient mining equipment. Small, portable boilers were replaced with large, stationary locomotive boilers. Single-drum hoists replaced hand-cranked windlasses. Steam thawing equipment extinguished primitive wood-fires. This section will focus on the mining equipment that allowed the Fairbanks miners to extensively develop the local placers, creating a highly profitable mining district.

\footnotetext{
${ }^{22}$ Wimmler, Placer-Mining Methods and Costs in Alaska, 113.

${ }^{23}$ Wimmler, Placer-Mining Methods and Costs in Alaska, 123.
} 


\section{Boilers}

Fairbanks placer miners relied on boilers to create steam and power for nearly all equipment used during the boom years of 1902-1909. Boilers powered the hoists that lowered miners into shafts and raised paydirt out of them. Boilers sent steam to the thawing points and powered centrifugal pumps that sucked the seeping ground water and condensation out of the shafts during the summer months. A boiler is a container that is partially filled with water and heated, resulting in the generation of steam. ${ }^{24}$ Boilers, in the most generic sense, are composed of a shell, furnace, and the internal reservoir where water is stored and heated creating steam. The boiler's furnace is filled with either wood or coal (the former being the primary source in Fairbanks), which is ignited, heating the water in the partially filled reservoir, that is located above or adjacent to the furnace, and creating steam in the empty void above the water line. The steam rises and is harnessed from the boiler through a steam pipe, where it transferred and its energy is used to either power ancillary mechanisms through its pressure or used to heat adjacent buildings. Boilers are used within a number of industrial and domestic ventures and are found on land, sea and rail. This section will detail only the boilers that were used within the Fairbanks Mining District, specifically the portable prospecting boilers used in the early years and the mass produced, internally fired, stationary boilers that found employment later.

Early boilers in the Fairbanks district fell into two categories, the porcupine boiler and the doghouse boiler, both of which were constructed locally. These early boilers functioned only as producers for steam thawing, as hoisting was carried out by hand or animal windlass. The porcupine boiler was the lighter model of the two early boilers and its internal composition resembled the raised quills of a porcupine (see Figure 5.7). The porcupine boiler is an externally fired,

\footnotetext{
${ }^{24}$ C.B. Lindstrom, Steam Boilers and Equipment (International Textbook Company: Scranton, 1928) 1.
} 
single flue water-tube boiler. The porcupine boiler is housed in a shell similar to that of a vertical boiler, tapering off as it reaches the stack on the apex of the shell. ${ }^{25}$ Underneath the porcupine boiler a fire is built in a small pit, externally firing the boiler. Directly above the fire and within the boiler is a water box.

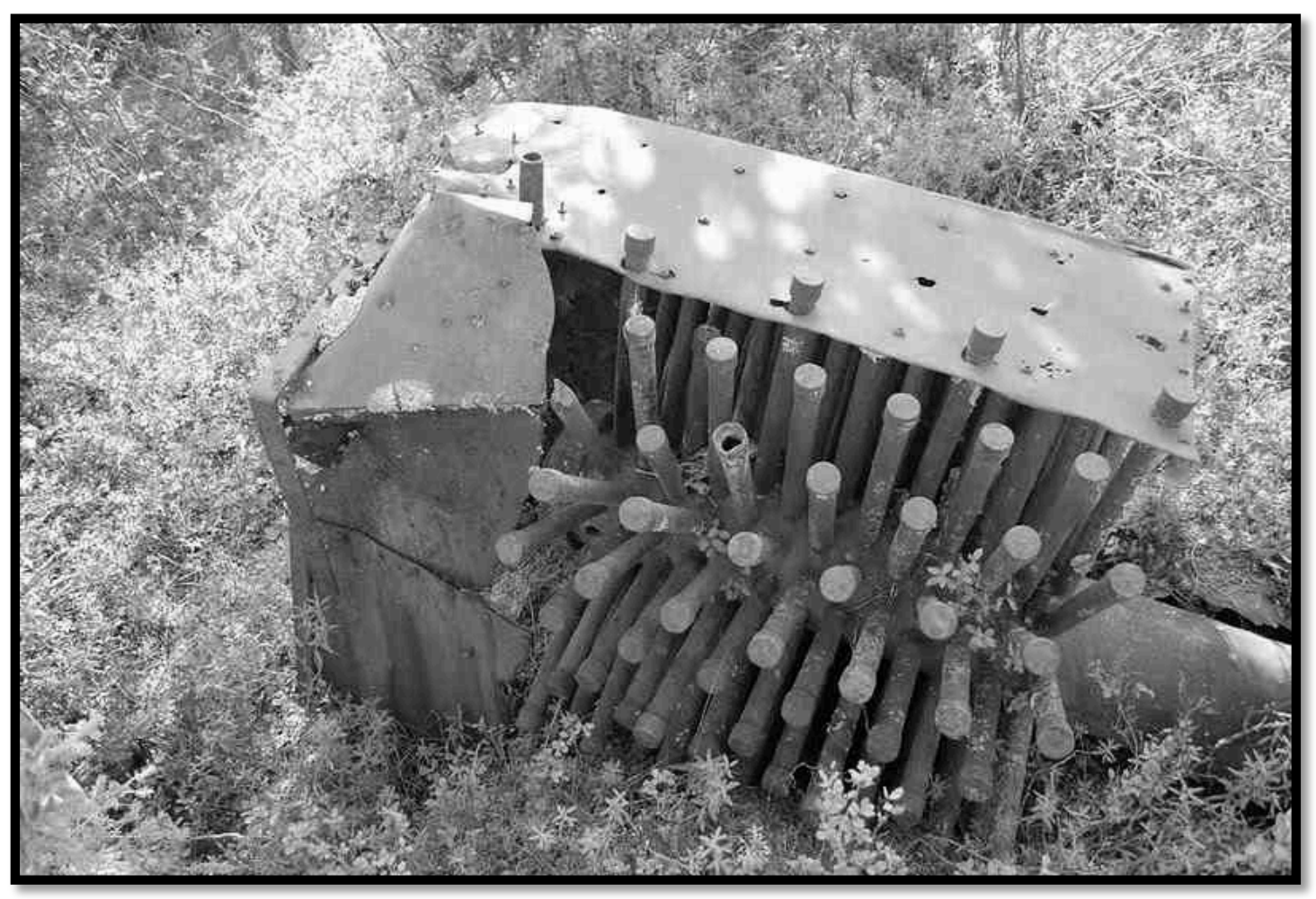

Figure 5.7: Porcupine boiler (Goddard 2010)

The heating core of the porcupine boiler consists of a main water-tube that is fitted with short pipes, or quills, running around its diameter. The pipes are capped and arranged in close proximity around the outside of the fire tube in all directions. ${ }^{26}$ The heating core is placed in the water box and fed water from a pump that injects water into the top of the main tube. ${ }^{27}$ The injected water seeps

\footnotetext{
${ }^{25}$ Ernest Wolff, "Handbook for the Alaskan Prospector", Mineral Industry Research Library (Fairbanks: University of Alaska, 1967) 217.

${ }^{26}$ Parker, The Evolution of Placer Mining Methods in Alaska, 30.

${ }^{27}$ Parker, The Evolution of Placer Mining Methods in Alaska, 30.
} 
into the smaller pipes running off of the main tube and begins to boil with the heating of the boiler. As the water in the quills boils, steam travels up the main water tube and is collected at the top by an additional hose or pipe that transfers the steam to thawing points. ${ }^{28}$

The other early prospect boiler in the district, the doghouse boiler, also received its name due to its appearance, resembling a small doghouse (see Figure 5.8). The doghouse boiler is an internally fired, single flue water-tube boiler. The shell of the doghouse boiler is composed of sheet metal and shaped like a rectangle, containing a fuel door at its front and stack located at the rear. Inside of the firebox, water-tubes are aligned horizontally and set around the entire surface of the firebox, connected together at their ends ${ }^{29}$. The water-tubes are connected to a larger, vertically placed tube, located at the rear of the boiler within the smoke stack. ${ }^{30}$ After the boiler is fired, water is injected into the water tubes, sending steam into the vertically placed tube near the boiler's end. The steam is harnessed in pipes located on the stack and then sent to steam points.

\footnotetext{
${ }^{28}$ Wolff, Handbook for the Alaskan Prospector, 217.

${ }^{29}$ Wolff, Handbook for the Alaskan Prospector, 217.

${ }^{30}$ Wolff, Handbook for the Alaskan Prospector, 217.
} 


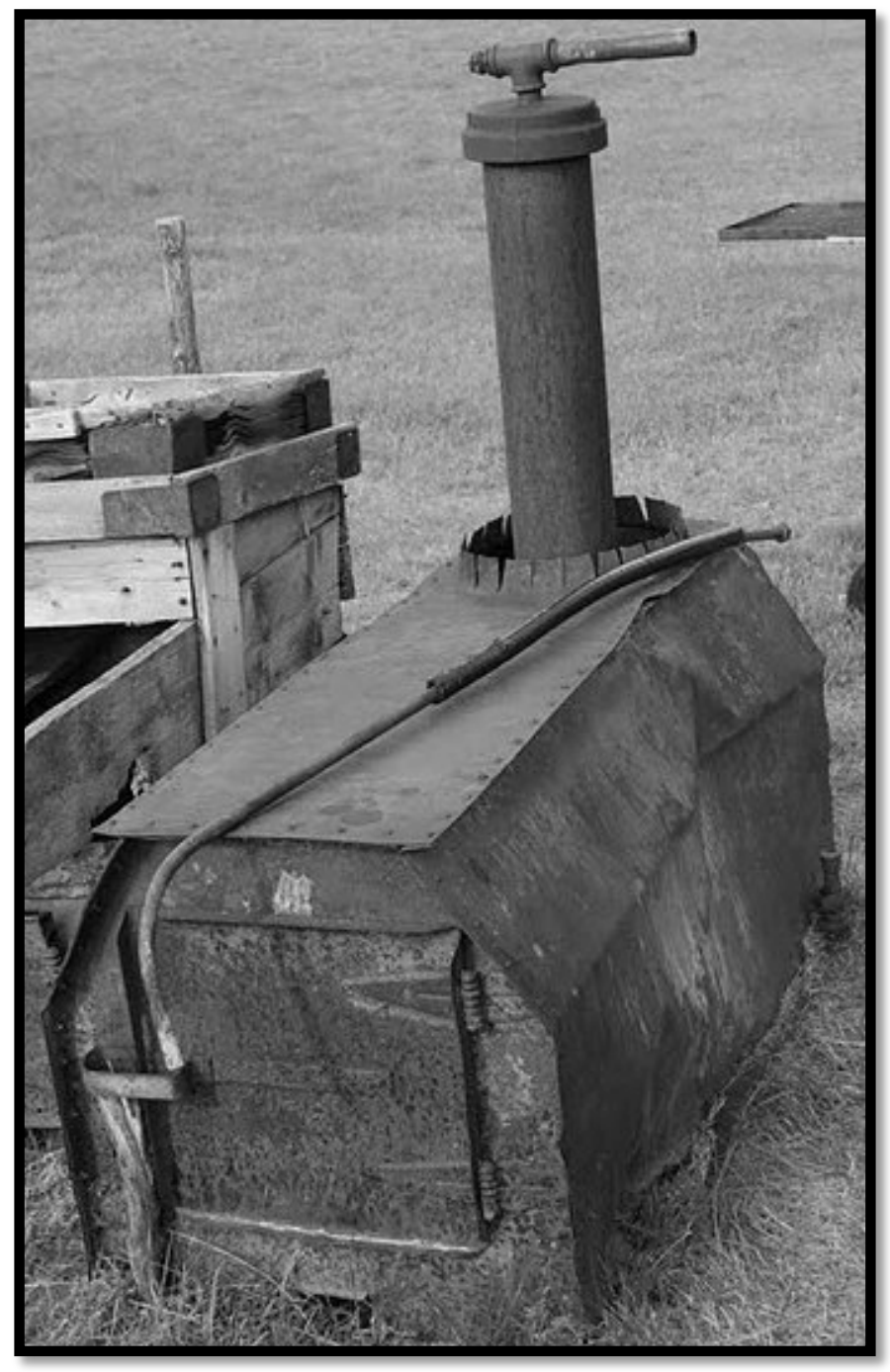

Figure 5.8: Doghouse boiler (Goddard 2010)

Mass produced boilers are classified by three characteristics: their physical orientation, internal composition and specified use. ${ }^{31}$ Boilers are first classified by their physical orientation as either vertical or horizontal. Vertical boilers are generally self-contained, meaning that no secondary structure is

\footnotetext{
${ }^{31}$ International Correspondence School Editorial Staff, "Steam Boilers: Settings, Trials, and Designs", International Library of Technology Vol. 357 (International Textbook Company: Scranton, 1924) S44-1. This volume is divided by sections each of which begins with a new numerical order, i.e., Section 44 page 1.
} 
needed to house their components. Due to their compact size, vertical boilers are primarily used in smaller mining operations, where they can be situated conveniently in the corner of a powerhouse or on a small foundation adjacent to the shaft. The bottom-up orientation of vertical boilers has drawbacks; they produce lower pressure steam and are inherently inefficient fuel burners as their arrangement encourages rapid combustion. ${ }^{32}$ Vertical boilers are prone to throw sparks and explode more frequently than horizontal boilers, posing significant risks to miners working nearby. ${ }^{33}$

Horizontal boilers generate a greater output of horsepower than their vertical cousins of comparable size, making them the ideal power source for larger and more advanced mining operations (see Figure 5.9). The head of the boiler is the main area of activity for the boiler operator (see N, Figure 5.9). At the head of the boiler fuel is added to the boiler's furnace through the fuel door. Below the fuel door the resulting ash from firing the boiler is removed through the pit door. The head of the boiler also contains gauges (see M, Figure 5.9) that display the current pressure and water level of the boiler. The fuel is heated in the furnace or firebox (see F, Figure 5.9), which is surrounded by enclosed spaces that are filled with water, called water legs. The combustion of the fuel creates gasses that pass through horizontally arranged fire-tubes (see T, Figure 5.9) that are surrounded by water. The water level needs to be carefully monitored; as steam is created the water level dissipates requiring the boiler tender to add water through a feed pipe attached to the head of the boiler, just above the furnace. ${ }^{34}$ After the gasses and smoke pass through the fire-tubes

\footnotetext{
${ }^{32}$ Ellis, Mining Methods at Fairbanks, 13.

${ }^{33}$ International Correspondence School Editorial Staff, Steam Boilers: Settings, Trials, and Designs, S44-16.

${ }^{34}$ International Correspondence School Editorial Staff, Steam Boilers: Settings, Trials, and Designs, S 45-30.
} 
they exit through the adjacent smoke box and are expelled through a stack, located on the top of the boiler. The hot gasses that pass through the fire-tubes heat the water surrounding them, causing the water to change from a liquid to a vapor, steam. As steam is created it rises and is collected in steam pipes located in a dome on the top of the boiler, opposite the stack. ${ }^{35}$ The dome is a capped cylinder, which functions as an additional space for steam storage (see H, Figure 5.9). The dome also contains a manhole cover that is used for access to clean and inspect the boiler.

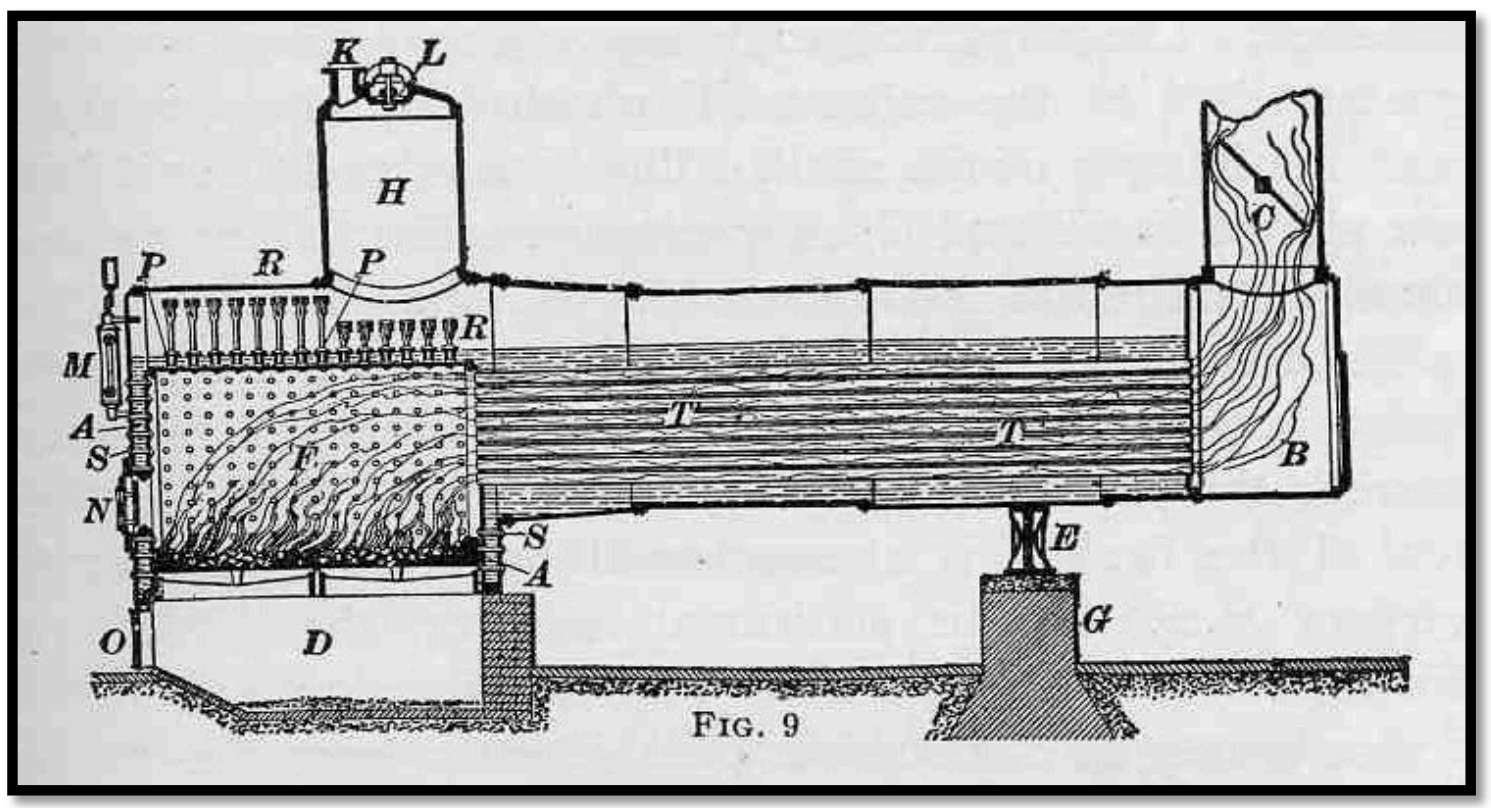

Figure 5.9: Locomotive Boiler (International Library of Technology 1924:13)

The typical horizontal boilers used within the Fairbanks district were the Scotch marine and the stationary locomotive boiler. ${ }^{36}$ The Scotch marine boiler is an internally fired, return-flue fire-tube boiler. Miners in the Fairbanks district employed the Scotch marine boiler at midscale placer mines, or those operating

\footnotetext{
${ }^{35}$ International Correspondence School, A Treatise on Metal Mining, Vol. II (Scranton: The Colliery Engineer Co., 1899) 30-32.

${ }^{36}$ Ellis, Mining Methods at Fairbanks, 13.
} 
plants at less than 30 horsepower. ${ }^{37}$ The Scotch marine boiler is generally found in seafaring vessels, but became a popular choice for miners in the Fairbanks district, possibly due to Scotch boiler's large quantity of small diameter fire-tubes that create a proportionately high area of surface heating in contrast to the overall size of the boiler. Scotch marine boilers are constructed in a variety of manners, composed of anywhere from one to four furnaces, single or double ends, and from 9 to 21 feet in diameter and lengths of up to 12 feet, with the Scotch boilers used in Fairbanks undoubtedly on the small end of the spectrum. ${ }^{38}$ The interior of the firebox is corrugated, assisting in reducing the expansion that occurs during the firing of the furnace and the creation of steam. ${ }^{39}$

The larger mines generally relied on stationary locomotive boilers that produced up to 100 horsepower outputs of steam. ${ }^{40}$ The stationary locomotive boiler, as its namesake suggests, resembles the boiler located on a train engine. The front of the locomotive boiler (see B,C in Figure 5.9) is the end that contains the stack and the rear is the end that contains the firebox, owing again to the resemblance to its mobile counterpart. Locomotive boilers occupied a greater surface area than vertical boilers, but also posed less threat of explosion, as "staybolts" and girders were aligned along the surface area of the firebox casing to help prevent bulging. ${ }^{41}$ The locomotive boiler's shell consists of two parts that are riveted together, a long cylindrical piece that hoses the fire tubes and a steel box that surrounds the furnace.

\footnotetext{
${ }^{37}$ Ellis, Mining Methods at Fairbanks, 13.

${ }^{38}$ International Correspondence School Editorial Staff, Steam Boilers: Settings, Trials, and Designs, S 44-30.

${ }^{39}$ Robert Peele, Mining Engineers' Handbook, $2^{\text {nd }}$ Edition (New York: John Wiley \& Sons, Inc., 1927) 2219.

${ }^{40}$ Ellis, Mining Methods at Fairbanks, 13.

${ }^{41}$ International Correspondence School Editorial Staff, Steam Boilers: Settings, Trials, and Designs, S 44-13,14.
} 


\section{Hoists}

Miners in the Fairbanks Mining District first used the hand windlass, a small-capacity primitive hoist. The hand windlass was operated by either one or two men and is located above a shaft or prospect (see Figure 5.10). The hand windlass consists of a horizontal base in which vertical beams are mortised into the center of opposing sides of the base, forming a triangle like shape. Diagonal posts, located next to the vertical members, are affixed to the base and support the upright members. ${ }^{42}$ A round pole, called a drum, is placed lengthwise inbetween the vertical members. On the ends of the drum are two pipes that are placed within slits cutout of the top of the vertical members. The drum is wound with rope and is rotated by a hand-crank that is attached to the pipe at the end of the drum. A hand windlass may have one or two hand-cranks, depending on the necessary capacity required at the mine. When the hand-crank is rotated, the windlass either lifts a bucket attached to the rope or allows the bucket to descend into the shaft.

\footnotetext{
${ }^{42}$ Wolff, Handbook for the Alaskan Prospector, 317.
} 


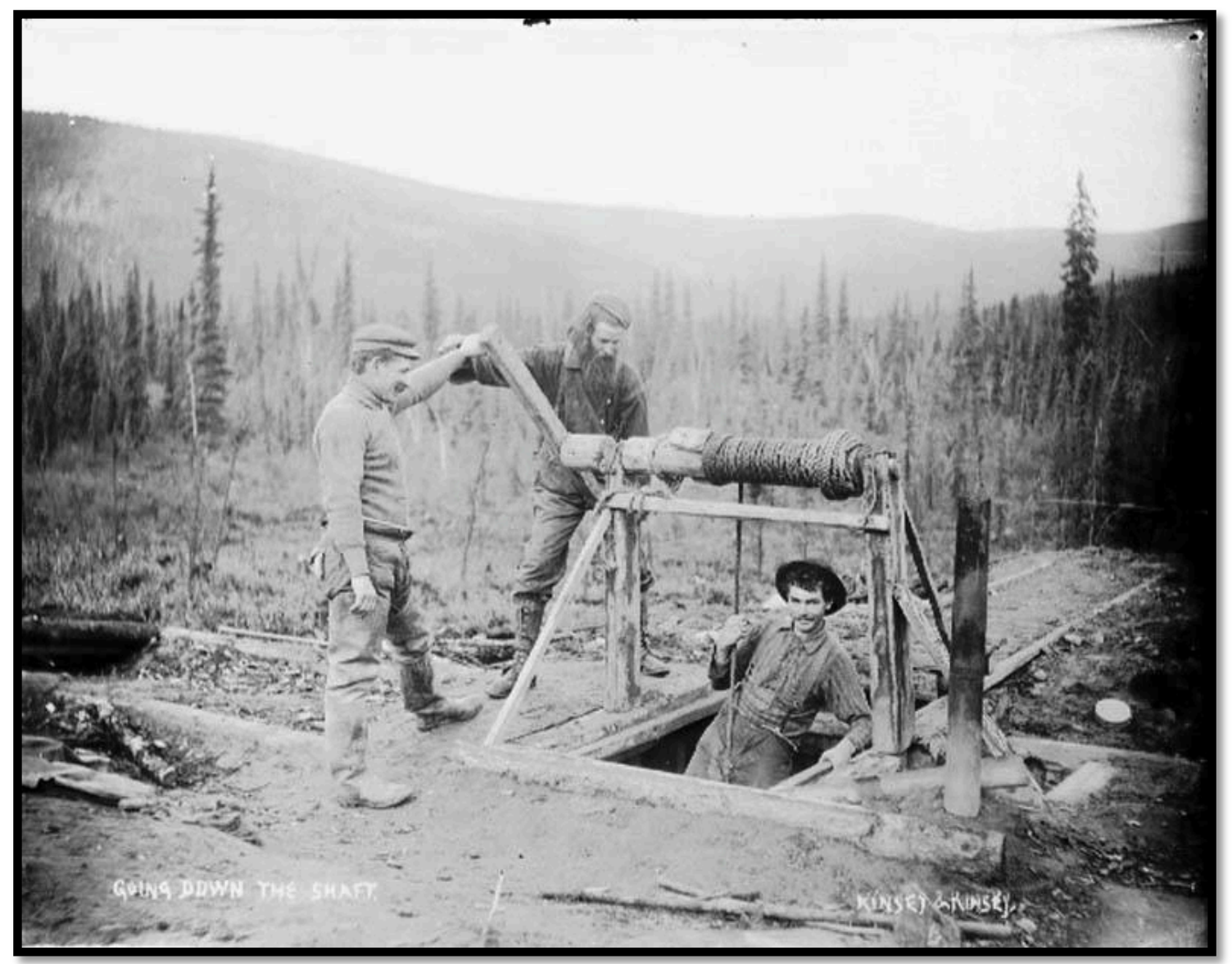

Figure 5.10: Hand windlass above shaft (Courtesy of University of Washington Libraries, Special Collections, William E. Meed Collection, UW16633).

As the Fairbanks district developed the hand windlass became relatively obsolete, except at small prospecting sites, due to the low capacity of the mechanism and its characteristically inefficient power source, the human. By 1908, less than 20 operators in the district were utilizing a windlass for hoisting purposes and these operations were focused primarily on prospecting or removing pillars from former drift mining locations. ${ }^{43}$ On average, miners operating the windlass could hoist 3.5 tons of material from a 100 -foot shaft in an

\footnotetext{
${ }^{43}$ Alfred Brooks, "The Mineral Resources of Alaska, 1908", USGS Bulletin 379 (Washington:GPO, 1909) 195.
} 
8-hour day, a quantity exceeded by the more technologically advanced steam hoists. $^{44}$

Steam hoists are also fundamentally inefficient mechanisms; they operate intermittently and commence while lifting a full bucket from great depths, utilizing excessive amounts of fuel from the get-go. Steam hoists, like all equipment in the area, varied in capacity, but the predominant type in the Fairbanks district tended to be the single-drum type. ${ }^{45}$ The single hoist is constructed in a similar manner to the previously described hand windlass. The lone drum is wound with cable that is affixed to a bucket. Instead of a hand crank, an engine powers the single drum hoist. The hoist's engine varied between one and two cylinders, which were oriented either horizontally or vertically. ${ }^{46}$ The number of drums per hoist grew proportionately with the size of the mine, with up to three drums being found in some of the larger open-cut mining operations. ${ }^{47}$

The hoisting drum is wound with braided or locked-coil cable, called the hoisting cable, and it runs through a sheave attached to the gin pole. From the gin pole, the hoisting cable runs back towards the shaft and runs through a sheave on the carrier then through an additional sheave located on the bucket's bail. The hoisting cable then runs back towards the carrier and is affixed to a hinged 'hammer' on the carrier's side nearest the hoist. ${ }^{48}$ The hoisting operation consists of four main components: the hoist, the bucket, the gin pole and the carrier. Of these components, the Fairbanks self-dumping carrier had the biggest impact in the hoisting practice during the drift mining boom years in the Fairbanks Mining District.

\footnotetext{
${ }^{44}$ Robert S. Lewis, E.M., Elements of Mining (New York: John Wiley \& Sons, 1933) 162.

${ }^{45}$ Ellis, Development Methods at Fairbanks, 1024.

${ }^{46}$ Ellis, Development Methods at Fairbanks, 1024.

${ }^{47}$ Ellis, Development Methods at Fairbanks, 1024.

${ }^{48}$ Ellis, Development Methods at Fairbanks, 1024.
} 


\section{Self-Dumping Carrier}

The self-dumping carrier is an apparatus that connects with the hoisting cable and transports a bucket to and from the shaft (see Figure 5.11, 5.12). Along with the hoisting cable, the Fairbanks self-dumping carrier utilizes an additional cable, the trolley cable, during its operation (see Figure 5.12). The trolley cable is anchored to the top of the gin pole, located just above the sheave that the hoisting cable runs through. From the gin pole the trolley cable passes through the carrier and runs just past the shaft where it is anchored to the ground. Two sheaves on the top of the carrier rest on top of the trolley cable and guide the carrier as it moves from the shaft to the gin pole.

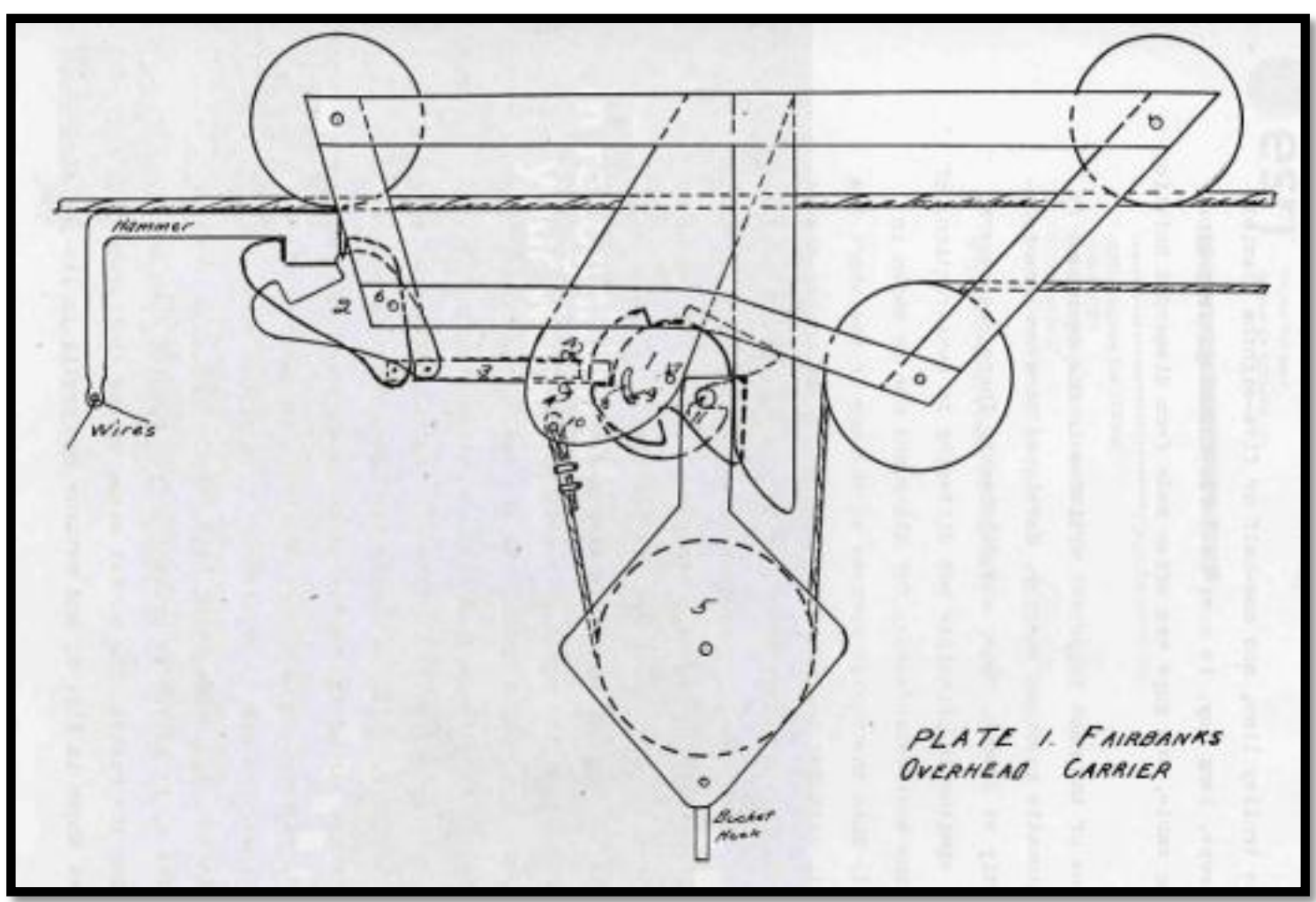

Figure 5.11: Diagram of carrier (Ellis 1915:14).

The Fairbanks self-dumping carrier's main improvement over the traditional bucket and cable hoist was based on its reliance on automation 
compared to manpower. Traditional hoisting apparatuses required a worker to be placed near the shaft, to transfer the bucket from the hoisting cable to the trolley cable, along with another worker near the dumping side, to flip the bucket and dispel its contents. The Fairbanks self-dumping carrier utilizes simple levers and locking mechanisms to transfer the bucket automatically from the hoisting cable to the trolley cable and releases its contents independently at the dumping site, making the process streamlined and cost effective.

After the bucket is filled in the shaft station it is lifted towards the surface, where the Fairbanks self-dumping carrier is situated, just above the shaft and adjacent to the headframe. The bucket's bale contains a sheave whose frame projects upward and past the sheave (see 5, Figure 5.11). Located at the top of this frame is a bolt that passes transversely through the frame. As the bucket is hoisted out of the shaft the bolt in the frame interacts with a cam, or tumbler, located on the carrier (see 1, Figure 5.11). The bolt contacts the cam and moves up its right side, rotating it counter clockwise until the bolt falls into a slot within the cam body (see 11, Figure 5.11). Once the bolt falls into the slot within the cam, the bucket is joined with the carrier and the trolley cable system. During the rotation of the cam a separate lever is engaged that releases a clasp that is attached to the headframe (see 2, Figure 5.11), freeing the carrier from its locked position and allowing it to travel up the trolley cable.

After the bucket is affixed to the carrier and the clasp released from the headframe the trolleying system begins. Adjacent to the shaft, on the side nearest the gin pole, an additional cable, a "tripping cable", is anchored to the surface. ${ }^{49}$ On the free end of the tripping cable a hook is attached that slides over a chain attached to the right side of the bucket. The length of the tripping cable is adjusted to compensate for the size of the dump around the gin pole, becoming shorter in length as the pile expands. When the tripping cable catches,

\footnotetext{
${ }^{49}$ Ellis, Development Methods at Fairbanks, 1024.
} 
the bucket pivots at the connection between the bale and the bucket, dumping the contents of the bucket onto the dump (see Figure 5.12). After the bucket dumps its contents the hoist discontinues its operations, allowing the bucket to freely travel back down the trolley line and stop above the shaft.

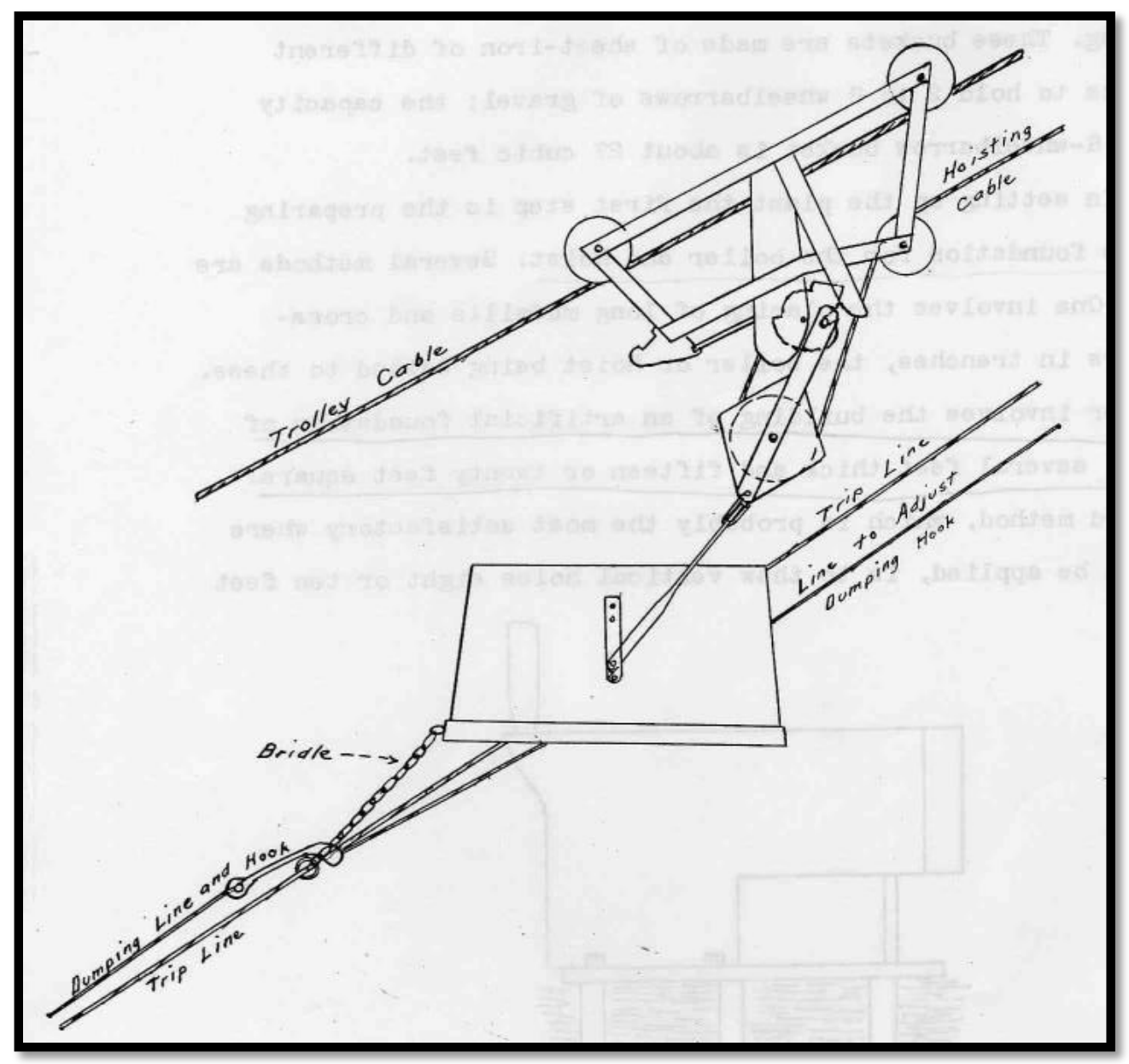

Figure 5.12: Operation of carrier wbile dumping (Ellis 1915:15)

\section{Headframes}

Headframes are supports constructed over shafts in the deeper and more developed drifting operations in the Fairbanks district, used to support the hoisting sheave, cables and carrier. The typical headframe in the Fairbanks district is constructed in a manner similar to the Montana Type, consisting of a 
lumber frame arranged around the shaft like a tripod (see Figure 5.13). ${ }^{50}$ The headframe is composed of a wooden base that extends past the edges of the shaft's sides and creates a square foundation above the shaft. On top of the headframe's foundation two logs are vertically arranged above the shaft, nearest to the hoist. The vertical logs measure roughly 1 -foot in diameter and stand 6 feet tall and are angled slightly inward over the shaft. The trolley sheave is affixed on top of an additional 6-foot log that is placed horizontally on top of the vertical posts. Supporting the vertical posts are front and back braces that extend diagonally from the top of the vertical members almost to the ends of the baseframe.

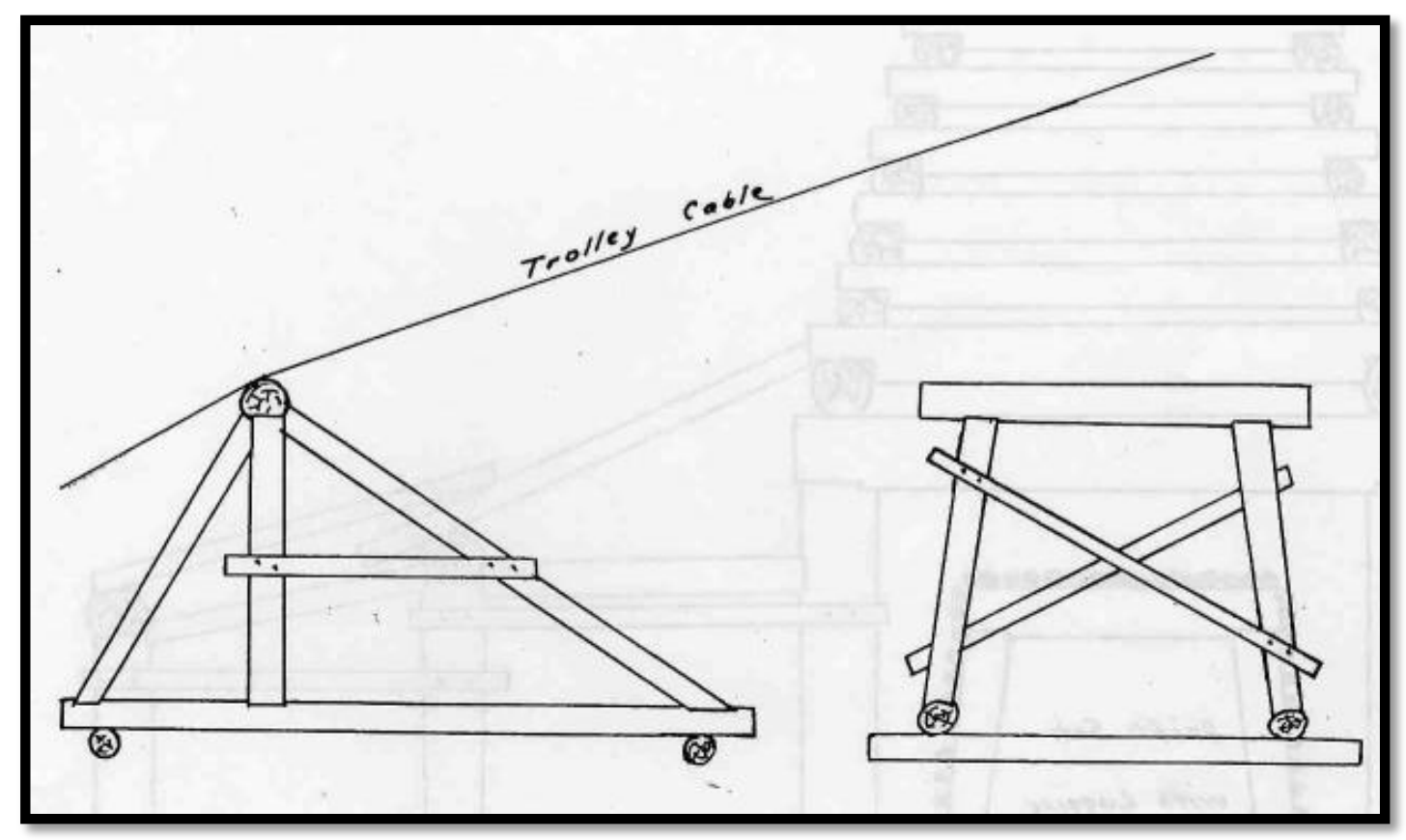

Figure 5.13: Typical Fairbanks Headframe (Ellis 1915:18).

\section{Steam Points}

The practice of thawing by steam in frozen gravels supposedly began by accident in the Klondike gold fields in the late 1890s. At this time miners were

\footnotetext{
${ }^{50}$ Peele, Mining Engineers' Handbook, 1091.
} 
still using fires, heated stones and hot water to thaw frozen gravels and overburden as they searched for paydirt. Clarence Berry, a miner in Dawson, employed a steam hoist at his placer mine, using it to haul logs to his boiler. While operating the hoist a hose from the boiler became loose or sprang a leak and subsequently emitted steam onto the surface. When Berry eventually located the dysfunctional hose, he found that the surrounding ground had been thawed and that he could push the ruptured hose into the thawed overburden accelerating the thawing process. ${ }^{51}$ Berry's misfortune turned out to be serendipitous, as the deviated hose led to the development of a variety of devices aimed at thawing the frozen gravels, culminating with the steam point.

The steam point is essentially a steel rod that receives steam at one end and expels steam at the other end (see Figure 5.14). Steam points have undergone numerous modifications from their invention, from crude devices, like welded rifle barrels, to hollowed drill steels and finally manufactured steam points. Steam points consist of a head, nipple, stem and bit. The head of the steam point is the end that receives steam from a hose connected to a boiler. The head originally was constructed out of cast or wrought iron, but as the development of the points progressed the composition of the head changed from iron to tool steel, a material more amenable to the super heated conditions. The head receives blows from a mallet while driving the point into the frozen gravels. Driving the point entails hammering the head of the point while slowly rotating the body until the point stops advancing. ${ }^{52}$ The point is rotated by a pipe that is inserted into a small hole drilled into the stem of the steam point just below the

\footnotetext{
${ }^{51}$ Parker, The Evolution of Placer Mining Methods in Alaska, 27.

52 George J. Young, Elements of Mining, $3^{\text {rd }}$ Edition (New York: McGraw-Hill Book Company, 1932) 466.
} 
head.

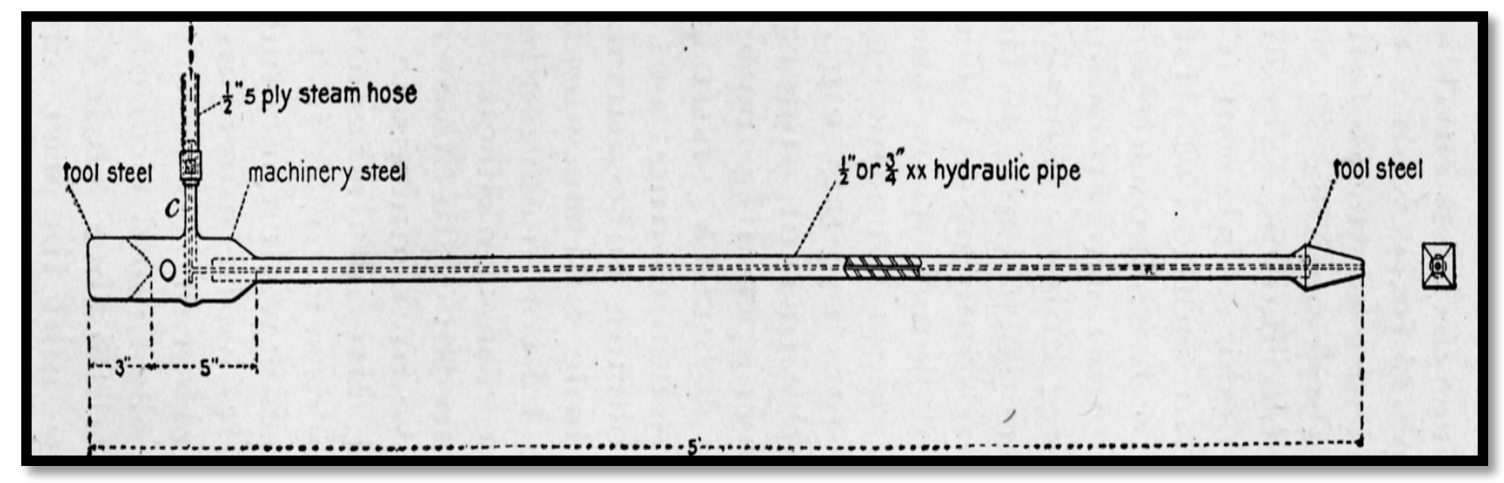

Figure 5.14: Steam point (Purington 1905:90).

On the head, near its juncture with the stem, a small pipe called a nipple is welded onto the steam point. The nipple runs perpendicular to the point and steam enters the nipple from a hose running from the boiler. The composition of the nipple changed over time with later versions being constructed out of modified boiler rivets or solid pipes that were hollowed out after being welded onto the head. ${ }^{53}$ While driving steam points miners often hit and dislodged the nipple requiring servicing from a blacksmith, adding a cost of upwards of $\$ 2.50$ to fix the nipple on top of the time lost of while the point was out of service. ${ }^{54}$ This problem led to the development of nipples that ran parallel with the stem, lessening the chance of being hit while driving.

Bits are the open tips of the steam point that expel steam and are located on the end opposite the head. Bits on steam points underwent numerous alterations in their development. The first bits were constructed out of cast iron and had a conical shape, a form amenable to piercing the frozen gravels during driving. Over time bits changed from cast iron to tool steel, as miners found that

\footnotetext{
${ }^{53}$ Huber I. Ellis, "Thawing Methods at Fairbanks", The Engineering \& Mining Journal, Vol. 100, No. 1 (07-03-1915) 3.

${ }^{54}$ Parker, The Evolution of Placer Mining Methods in Alaska, 34.
} 
the new material held up better under constant driving. Miners also experimented with the shape of the bit, modifying the original conical form into diamond, chisel and the four-cornered Burleigh bit. ${ }^{55}$ Each of these bits found use depending on the composition of the gravel. Miners used the diamond bit in the softest gravels and switched to the chisel and Burleigh bit as they encountered harder gravels.

In contrast to the head, nipple and bit, the stem of the steam point underwent the least amount of modifications. Its original design consisted of a single steel pipe, with later varieties consisting of hydraulic piping, rifle barrels and finally hollow drill-steel stems. This design change only affected the stem's composition while its original function remained the same. ${ }^{56}$ Steam points are roughly 1 inch in diameter with a length that varied from a few feet to upwards of twenty feet in length. ${ }^{57}$ Shorter pipes were utilized during the initial thawing of the frozen deposit, as their size is less susceptible to breaking during the compressive impact of driving.

Instead of steam, miners often pumped hot water through the steam point to initially soften the top few inches of ground, allowing for easier driving of the points. ${ }^{58}$ The driving process can be time consuming; points can only be driven as far as the gravel has thawed, which at times means leaving them in place for up to 14 hours of continual thawing. Once a hole is formed in the frozen gravels, the steam point is removed and replaced with another thawing device called a sweater. Sweaters are less technologically advanced then steam points, resembling the same early thawing devices used in the late 1890s. These early thawing apparatuses were essentially capped pipes, or sometimes gun barrels,

\footnotetext{
${ }^{55}$ Ellis, Thawing Methods at Fairbanks, 3.

${ }^{56}$ Ellis, Thawing Methods at Fairbanks, 2.

${ }^{57}$ Wimmler, Placer-Mining Methods and Costs in Alaska, 125.

${ }^{58}$ Purington, Methods and Costs of Gravel and Placer Mining in Alaska, 92.
} 
that were connected to a hose running to a boiler. ${ }^{59}$ Sweaters cost roughly half that of steam points and allowed miners to continue thawing an area while at the same time using steam points to begin thawing in another (see Figure 5.15). Steam points were an expensive piece of equipment; they cost upwards of $\$ 1200$ for a complete 60-point outfit and were difficult to straighten or mend, often requiring the attention of a blacksmith. ${ }^{60}$ In the dark, foggy haze of a thawing drift, miners often bumped into a projecting steam point, bending it into an inoperable state, delaying the thawing process. On the other hand, sweaters were often purposely bent aside to make room for excavation since they could be easily straightened.

Most thawing occurs at night, allowing the gravels to soften so they can be easily extracted the following morning. Between 50 and 60 points are used when thawing a drift. The points are arranged in groups of 4 , called batteries, with each point thawing an average of just over 3 cubic yards. ${ }^{61}$ A battery of steam points thaws gravels faster and burns less fuel than the traditional fire method employed for nearly a decade prior to the introduction of steam points. ${ }^{62}$ During thawing the face of the drift that surrounds the steam point or sweater expands around the point creating a void prone to heat loss. Plugging the void with vegetable matter or gunnysacks combats this heat loss and helps keep the heat within the hole, accelerating the thawing process. ${ }^{63}$

\footnotetext{
${ }^{59}$ Ellis, Mining Methods at Fairbanks, 32.

${ }^{60}$ Ellis, Thawing Methods at Fairbanks, 5.

${ }^{61}$ Purington, Methods and Costs of Gravel and Placer Mining in Alaska, 92.

62 Purington, Methods and Costs of Gravel and Placer Mining in Alaska, 89-92. A battery of steam points will thaw just over 13 cubic yards in a night using $3 / 4$ of a cord of wood, compared to the full cord of wood used during fire thawing which softens only about 9 cubic yards of gravels. ${ }^{63}$ Peele, Mining Engineers' Handbook, 958-959.
} 


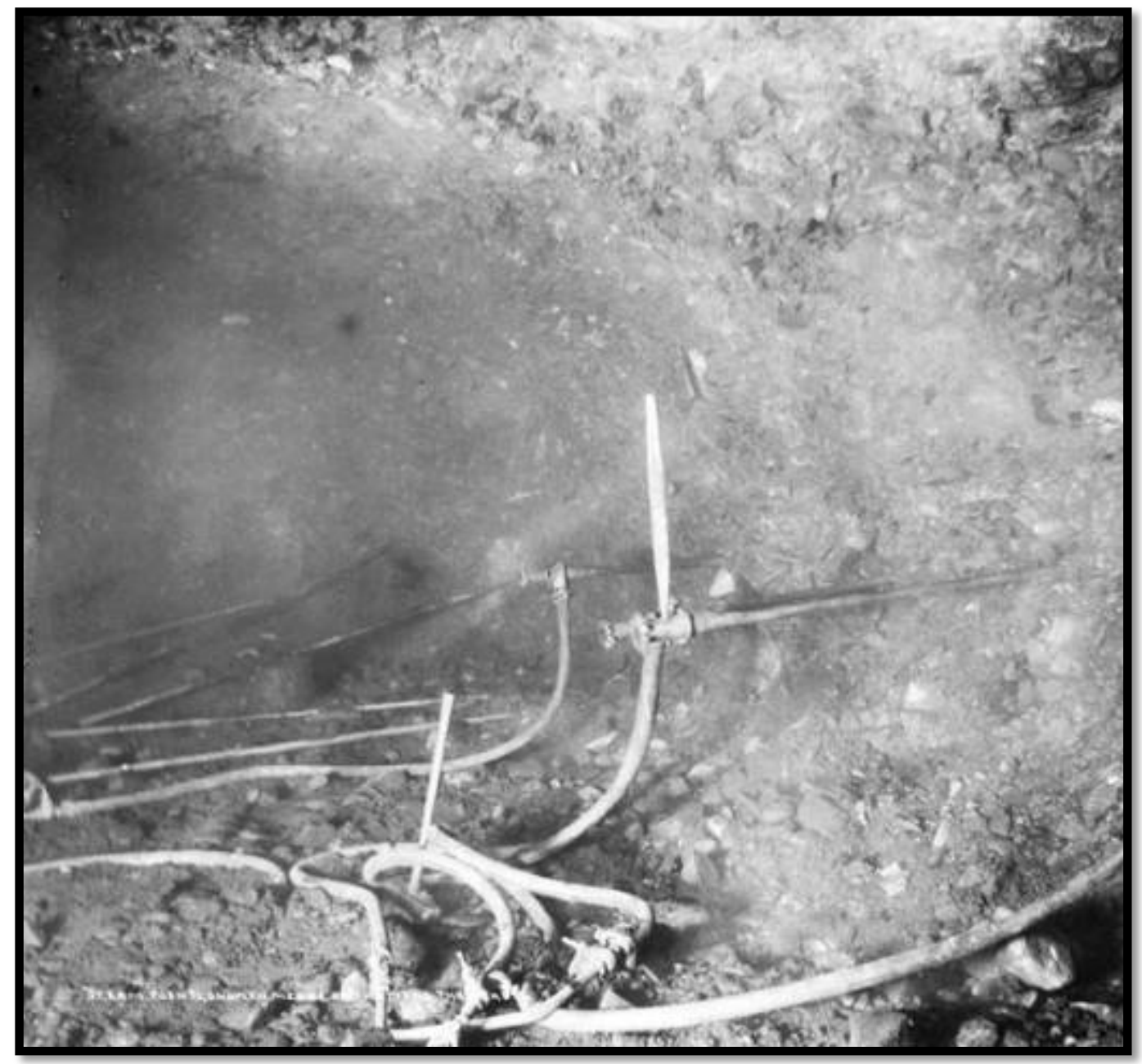

Figure 5.15: Sweaters in the drift (Courtesy of University of Alaska Fairbanks, Alaska and Polar Regions Collection, Albert Johnson Collection, Accession \#UAF-1989-166-633).

Within the drift, the hoses running from the battery of steam points are connected to the main boiler hose by a four-to-one manifold system consisting of valves, nipples and crossheads (see Figure 5.16). ${ }^{64}$ A clamp secures the hose that runs from the boiler to the steam point's nipple. The primary clamps used in the Fairbanks region were the Yoke clamp, similar to a U-Bolt, and the screw clamp, a modified version of the modern hose clamp. ${ }^{65}$

\footnotetext{
${ }^{64}$ Ellis, Mining Methods at Fairbanks, 24.

${ }^{65}$ Ellis, Thawing Methods at Fairbanks, 3.
} 


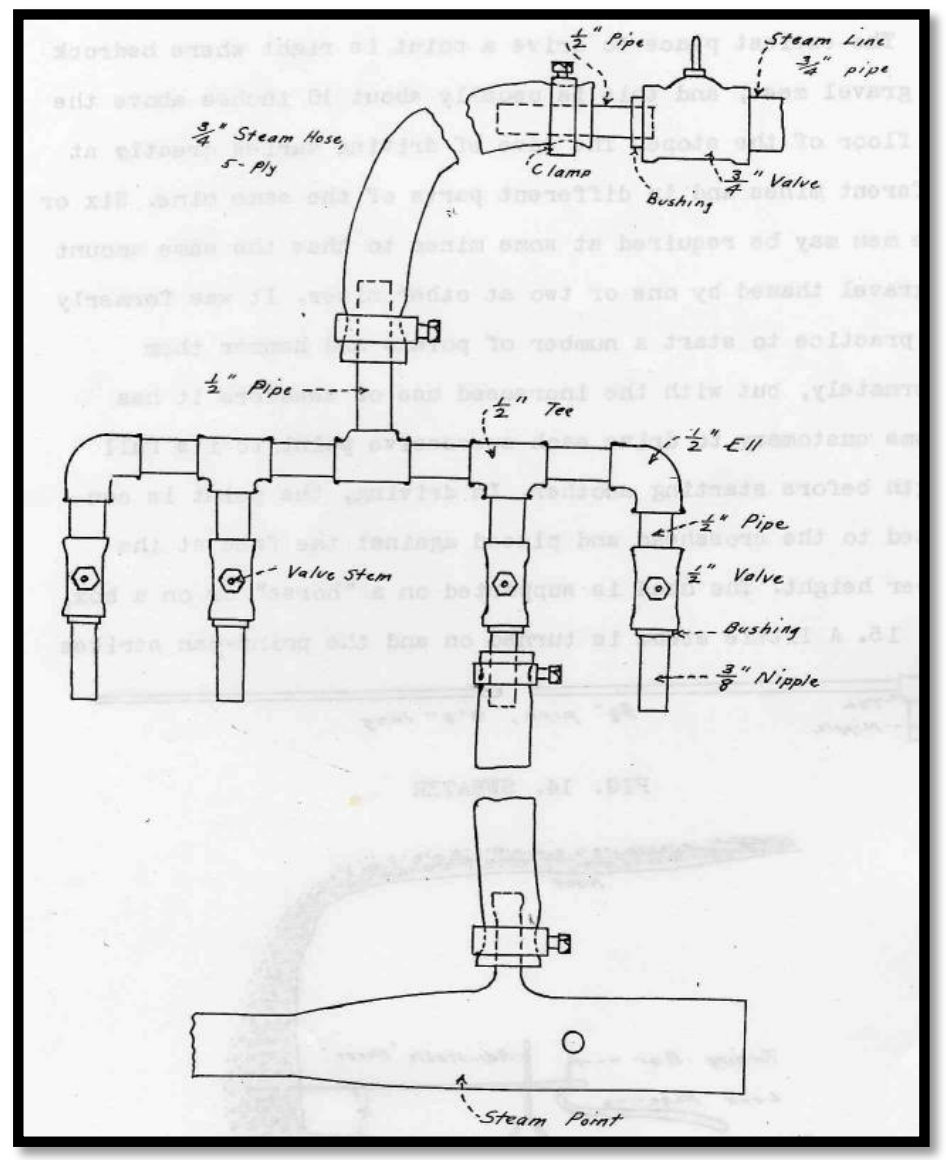

Figure 5.16: Example of steam pipe manifold (Ellis 1915:24).

The connection between the hose and the steam pipe's nipple required constant attention because the nuts securing the clamps would often loosen under the strain of driving.

Thawing frozen gravels was a costly affair for miners in the arctic; not only were the pieces of equipment costly to procure and maintain, but the immense amount of fuel needed to fire the mechanisms accounted for upwards of $20 \%$ of the total operating cost of the mine.$^{66}$ In 1907, miners in Fairbanks fed up with the high cost of thawing experimented with cold water, using unheated water in

\footnotetext{
${ }^{66}$ Wimmler, Placer-Mining Methods and Costs in Alaska, 128.
} 
the more loosely frozen gravels of the district. ${ }^{67}$ The results of these experiments showed some success, but cold water thawing wasn't fully implemented until the early 1920 s when the technique was patented in Nome. ${ }^{68}$ The cold water thawing technique utilized the majority of the same equipment used in steam thawing, with a gas-powered pump replacing the boiler as the feed source for the pipes. Cold water thawing created fewer environmental hazards within the drifts; omitting heat and steam made the roof more stable and the air within the drift less vitiated and foggy.

The shallow placers worked by dredges saw the most wide spread use of the cold water thawing technique. These shallow placers contained low-grade auriferous deposits unprofitable to exploit with traditional steam thawing techniques. A cost analysis study conducted by the Yukon Gold Co. in 1920 revealed that dredging operations utilizing steam thawing spent around $\$ 1$ to thaw 1 square yard, while cold water thawing cost less than $\$ 0.01$ per square yard. ${ }^{69}$

\section{Open-Cut Mining}

Open-cut mining is used to extract gold bearing alluvium from relatively shallow placer deposits. Open cut mining techniques include: shoveling-in, ground sluicing, derricking and mechanized scrapping. ${ }^{70}$ Chapter 2 describes the processes involving manual open-cut mining techniques; this section will focus solely on the prevalent mechanized open-cut mining techniques of scraping and derricking employed in the Fairbanks district during its boom years.

\footnotetext{
${ }^{67}$ Parker, The Evolution of Placer Mining Methods in Alaska, 39.

${ }^{68}$ Parker, The Evolution of Placer Mining Methods in Alaska, 40.

${ }^{69}$ Peele, Mining Engineers' Handbook, 961 . Note table 139. Steam thawing cost $\$ 52,844.88$ to thaw 61,832 square yards while cold-water thawing cost $\$ 89.12$ to thaw 27,188 square yards.

${ }^{70}$ Purington, Methods and Costs of Gravel and Placer Mining in Alaska, 55-82.
} 


\section{The Technique}

The focus in both drift mining and open-cut mining is reaching the auriferous material located at bedrock. Mechanized open-cut mining utilizes much of the same equipment as drift mining, including: boilers, hoists, and gin poles. Open-cut mining is employed when the alluvial deposit is located closer to the surface, up to 20 feet in depth, than those found in the deposits exploited by drift mining operations. The shallower deposit allows open-cut miners to still yield a profit, even while removing larger surface tracts of overburden. This section will describe the different methods of extraction and equipment used in placer mines employing the open-cut technique.

\section{Scraping}

Ground scraping originated as a technique to move and stack tailings from larger hydraulicking operations. As a tool for excavation in mines, the scraper had a relatively late introduction; it primarily functioned as a tool used to transport tailings in the early mines. A scraper is a large wedge, whose shallowest end is affixed with a bale that is connected to a cable running to a hoist. As the hoist winds the cable the shallow end of the scraper is pulled towards it, allowing the scraper to act as a tool of both excavation and transportation. The first step in the scraping process is the removal of the overburden and muck located above the paydirt. Removing the overburden consists of thawing the top layer of the surface and then either scraping it off or ground sluicing it towards an adjacent waste trench. ${ }^{71}$ After removing the overburden the equipment of the plant is installed and the mining operation can commence.

The hoist pulls the scraper by a length of braided cable that runs from the hoist to the top of a gin pole. From the gin pole the cable travels downward and connects with the bale of the scraper at ground level. On the opposite end of the

\footnotetext{
${ }^{71}$ Purington, Methods and Costs of Gravel and Placer Mining in Alaska, 66.
} 
scraper another length of braided cable is attached which passes through a ground anchor and back to the opposite drum of the hoist. The cable attached to the bale of the scraper pulls the scraper towards the gin pole along the surface of the deposit, while the cable attached to the scraper's back pulls the device back towards the excavation area. The cable attached to the back of the scraper can be adjusted to alter the path of the scraper across the excavation area by either shortening the cable or extending it. During the scraping operation, the hoist pulls the scraper across the surface of the deposit towards the gin pole, while one to two miners help guide the scraper along its path (see Figure 5.17). As the scraper approaches the gin pole it is raised off the ground and the contents in the scraper fall into a dump box that is adjacent to the gin pole. The dumpbox is lined with a series of parallel bars, called a grizzly, that functions to sort out the oversized material prior to sluicing. The material that passes through the grizzly falls into a sluice and is washed and sorted. This process continues until the scraper hits bedrock, with the entire length of the paystreak being exploited. Specific types of scrapers, like the Bagley bottomless and slip scraper will be discussed later in this section.

As the region's transportation system developed it became easier for larger machinery to enter the area. High powered steam shovels, bulldozers, backhoes and excavators replaced the traditional scraping equipment used to exploit the shallow placer deposits. Although the modern machinery is drastically different from the traditional ground scraping equipment the ground scraping technique is still essentially the same. The ground scraping technique experienced the greatest longevity of all open-cut placer mining methods in the Fairbanks region. 


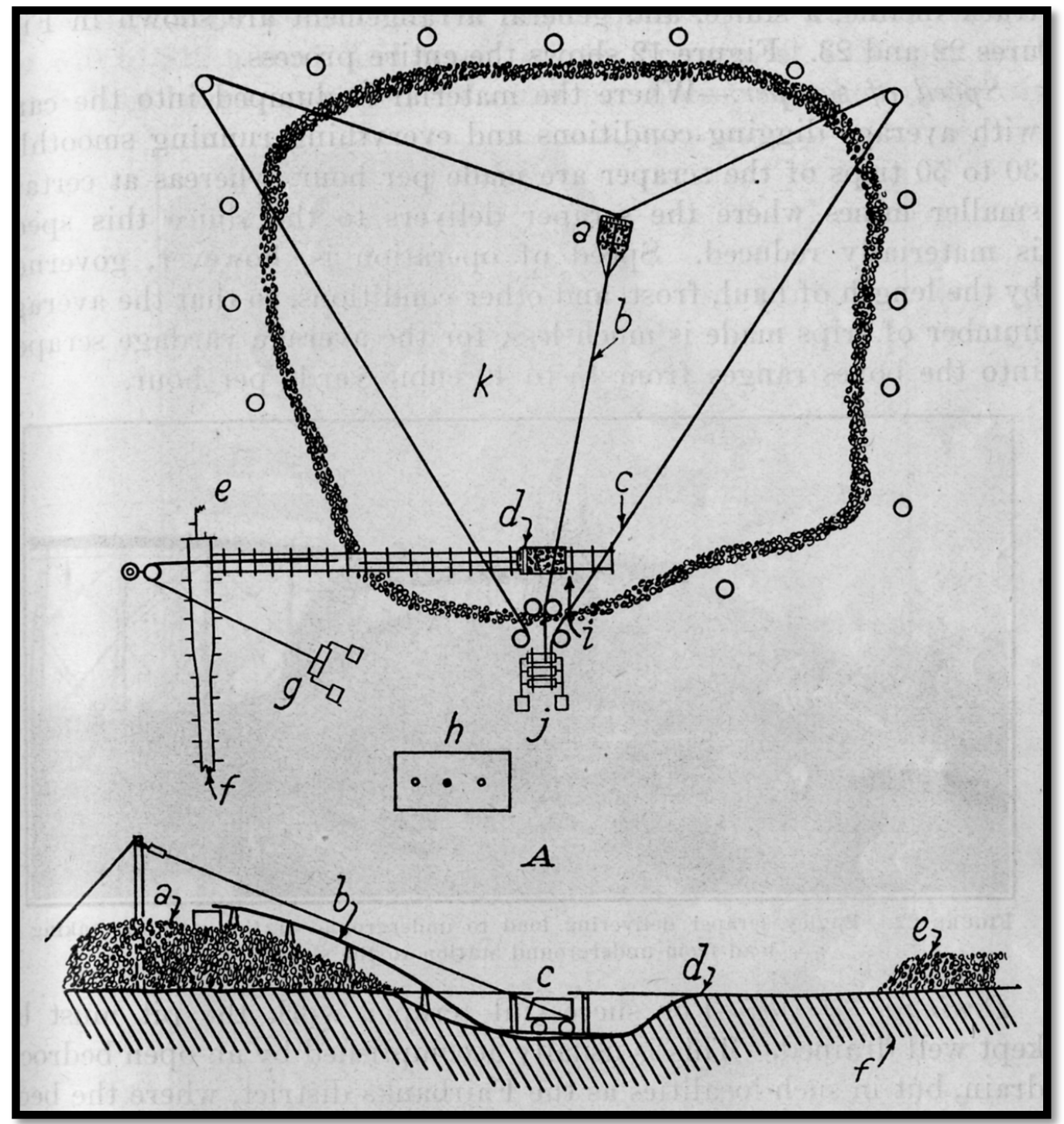

Figure 5.17: Plan of scraper operation (Wimmler 1927:97).

\section{Derricking}

Derricking is an open-cut mining technique that expedites the transportation of alluvial material from near the excavation site to the washing area. In derricking, miners extract the alluvium deposit manually with pick and shovel, basically digging up the deposit and then loading the alluvium into wheelbarrows that are pushed towards the derricking plant (see Figure 5.18). 


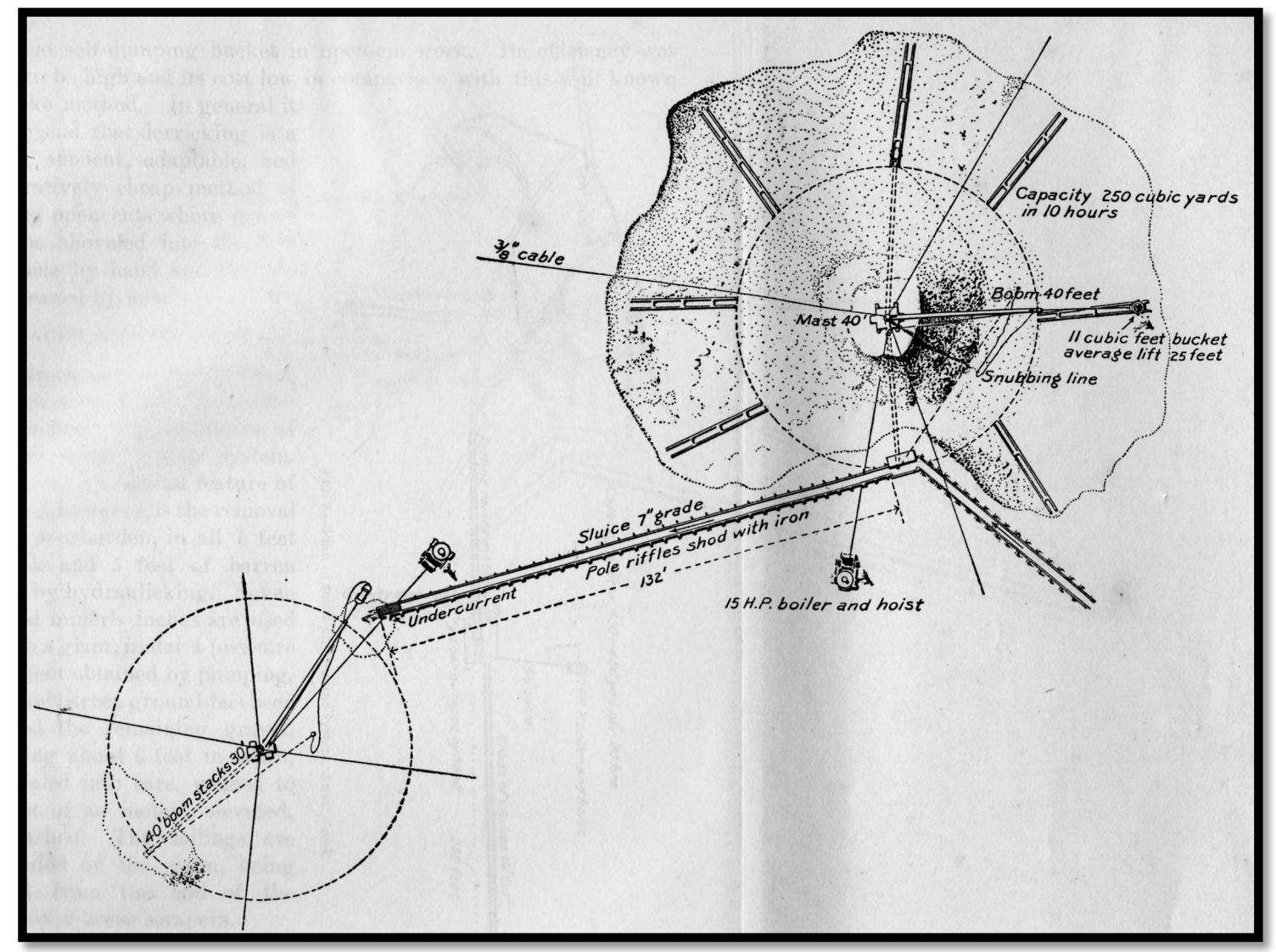

Figure 5.18: Overview of Derricking plant, note tailings derrick (Purington 1905:PL. X)

A derricking plant is composed of a main mast, located in the center of the excavation area, measuring around 40 feet in height that serves as an anchor for the operation. ${ }^{72}$ The mast is erected in a raised foundation and is stabilized by lengths of braided cable running from the top of the mast to anchors running along the outside of the main work area. Attached to the base of the mast is an identical 40-foot long pole, called a boom. The mast and boom are hinged together on a circular plate that allows the boom to move up, down and 360 degrees around the mast. On the top of the boom nearest the mast, a pulley system is attached that connects the boom with a corresponding pulley system on the mast (see Figure 5.19). A cable runs through these pulleys to raise and

\footnotetext{
${ }^{72}$ Purington, Methods and Costs of Gravel and Placer Mining in Alaska, 69.
} 
lower the boom to be raised or lowered. An additional cable and pulley system is located on top of the boom opposite the mast that attaches to a bale on a derrick bucket. A hoisting engine is connected to the pulley system attached to the derrick bucket. Attached to the apex of the boom is a rope, or snubbing line, that when pulled allows the boom to swing in a 360-degree route along the excavation area.

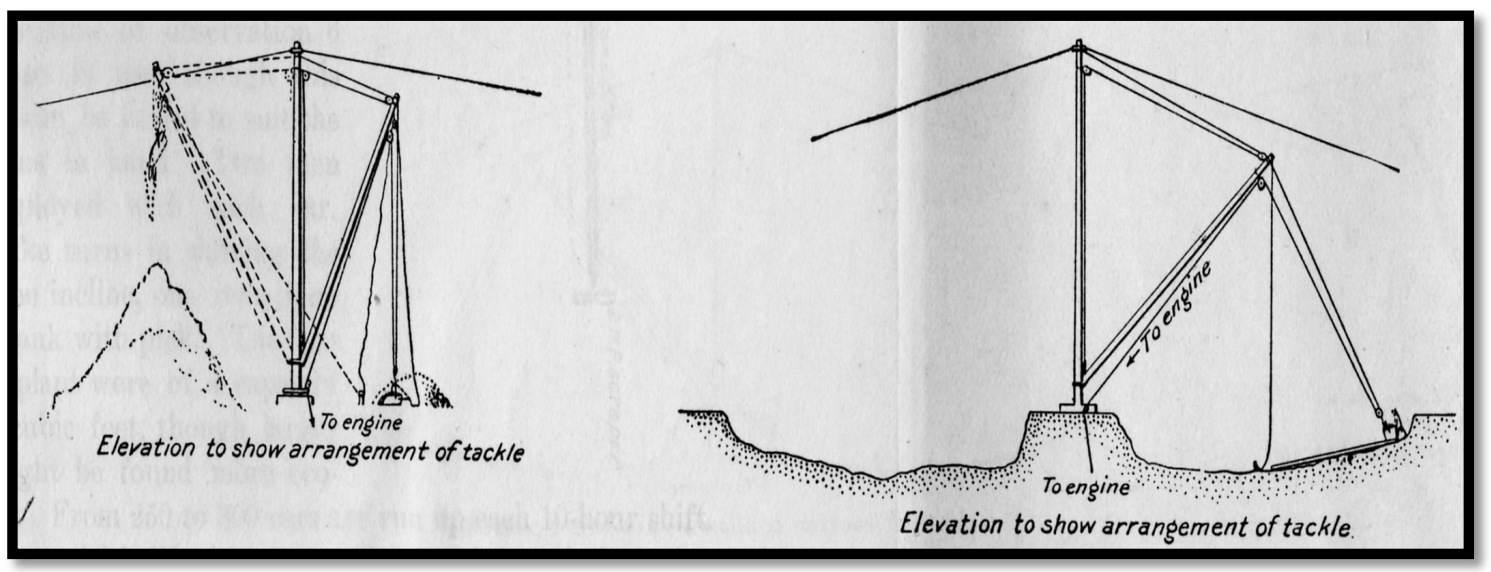

Figure 5.19: Elevation of derrick plant showing pulley system (Purington 1905: PL. X).

Timber skids are arranged in a circular pattern around the mast and placed at intervals along the edge of the excavation area. The skids are used to assist miners in transporting the derrick buckets from the excavation area to the derricking plant. Miners push the derrick buckets over skids towards the mast until the swinging boom can reach them. When the boom is situated above the bucket a hook from the boom is attached to the bucket's bale. After the bucket is attached, the snub line is pulled by hand and swings the boom towards the adjacent sluice box. The mast in this setup leans slightly toward the area where excavation is taking place, encouraging the boom to swing back towards the excavation area after the derrick box is emptied.

When the derrick bucket is above the sluice a miner located on a platform releases a catch located on the bale of the bucket that upends the bucket and 
empties its contents into a dump box (see Figure 5.20). ${ }^{73}$ The function of the dump box is to prevent loss and spillover of auriferous material during the upending of the bucket and to assist in transporting the paydirt to the lower line of sluice boxes. Ditches and flumes bring water to the sluices and carry the auriferous material across the box. The material that is not captured within the sluice travels over an undercurrent located at the end of the line of boxes that captures any remaining fines. The tailings that pass over the riffles and undercurrent spew out of the terminus of the sluice, where an additional tailings derrick is located.

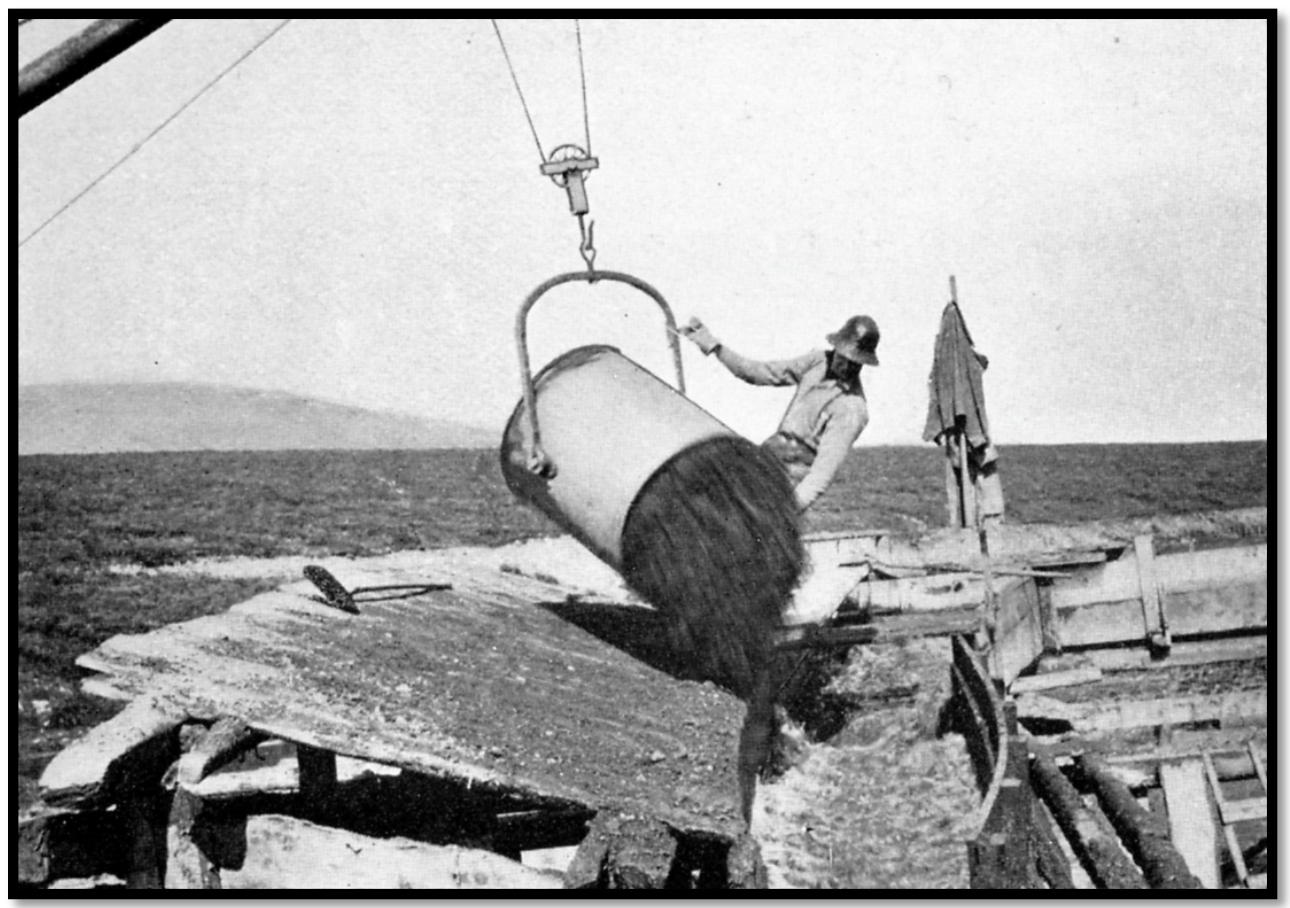

Figure 5.20: Miner emptying derrick bucket into sluice next to dump box (Purington 1905: PL. IX A)

The tailings derrick operates like an excavation derrick, but uses a selfdumping scraper to transport tailings rather than a derrick bucket. The tailings derrick transports waste from the sluice and deposits the tailings in piles opposite the washing area. The scraper is attached to a pulley system on the boom that

\footnotetext{
${ }^{73}$ Purington, Methods and Costs of Gravel and Placer Mining in Alaska, 68.
} 
runs to a hoist. The hoist pulls the scraper towards the tailings and is assisted by a miner guiding the scraper in the right direction. When full, the snub line is pulled and the scraper is swung away from the sluice where it empties its contents. Similar to the setup of the excavation derrick the mast in the tailings derricks leans towards the sluice box, encouraging the boom to return to the sluice after dumping its contents.

Derricking systems gained popularity early in the Fairbanks district; they provided to be an efficient and relatively inexpensive method for transporting alluvium. ${ }^{74}$ However, as the region developed miners began to acquire new machines and techniques to exploit the shallow placers. By 1908, approximately five years after its introduction into the Fairbanks district, the derricking technique was abandoned. ${ }^{75}$ Steam shovels and excavators replaced masts and booms, moving more gravel with efficiency that trumped the earlier techniques.

\section{The Equipment}

Boilers and hoists are used in both underground drift mining and open-cut surface mining. These pieces of equipment were described earlier. This section focuses on the pieces of equipment that excavated and moved the auriferous deposit from the point of excavation to the washing plant, specifically mechanically drawn steam scrapers and derricking buckets.

\section{Slip Scrapers}

Slip scrapers are full bottomed, small capacity scrapers (slip scrapers used in Alaska had an average capacity of about 1 cubic yard) used in the shallowest of open-cut mining operations (see Figure 5.21).

\footnotetext{
${ }^{74}$ Peele, Mining Engineers' Handbook, 895.

${ }^{75}$ Alfred Brooks, The Mineral Resources of Alaska, 1908, 194.
} 


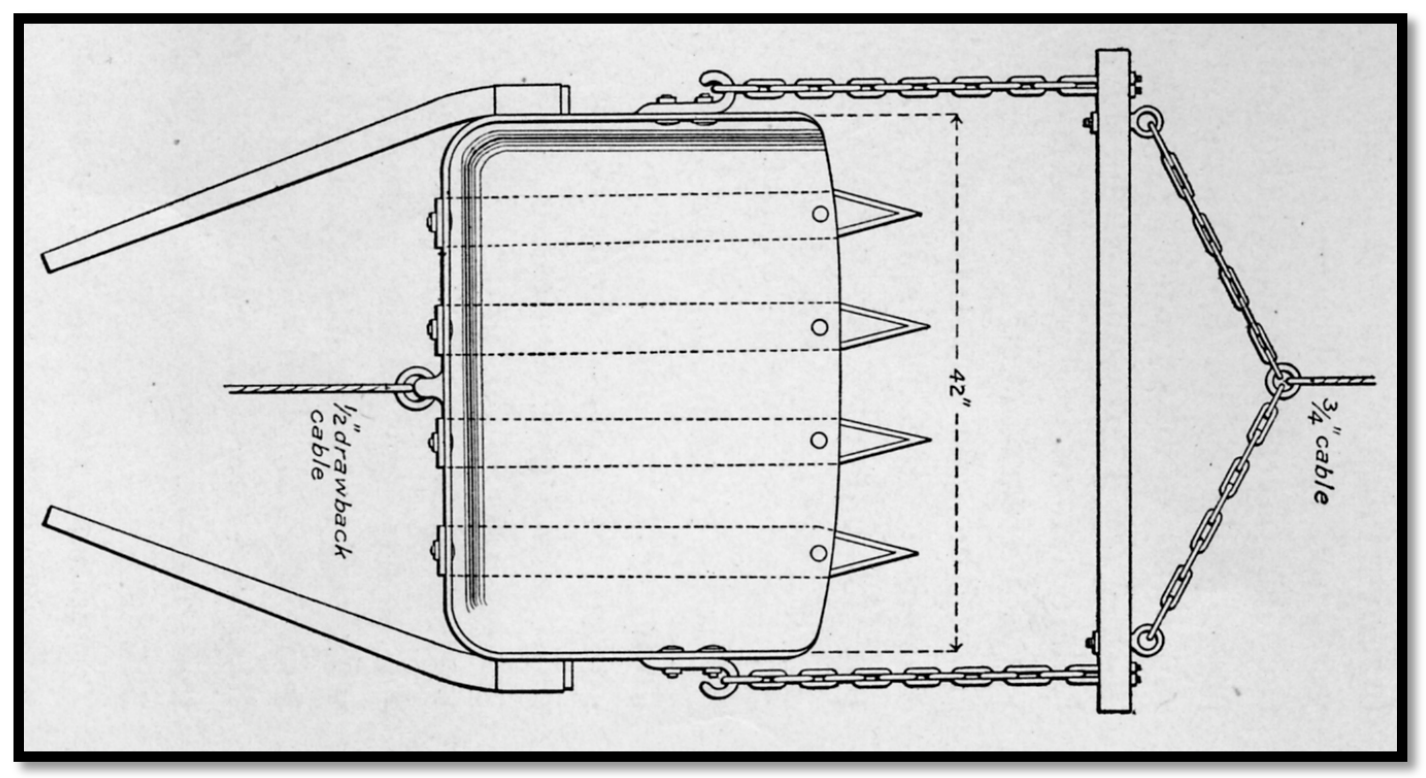

Figure 5.21: Slip scraper (Purington 1905:61).

The slip scraper is composed of a bale that is located on the front of the device, its digging edge, and attached to a cable running to the hoist. The digging edge is dressed with angled cast teeth that push through the surface and feed the loosened alluvium into the scraper. When operating, the hoist pulls the slip scraper towards an inclined timber skid while two workers place poles into holes located on the rear sides of the slip scraper. The poles are used as levers and lift the back of the slip scraper, forcing its teeth into the ground and digging up the alluvium. ${ }^{76}$ When the scraper is full its back is lowered and the scraper continues its path towards the inclined timber skids. As the scraper moves up the inclined timber skid the teeth of the scraper catch a lone timber placed perpendicularly across the top of the skid, effectively upending the scraper and dumping its load onto the dump box located below.

Slip scrapers proved to be adequate excavation tools in the shallow placers, effectively digging up the alluvium with their heavy cast teeth. During

\footnotetext{
${ }^{76}$ Parker, The Evolution of Placer Mining Methods in Alaska, 44.
} 
transportation slip scrapers became problematic, rarely making it to the timber skid with a full load. The slip scraper lost up to half of its contents during its final ascent to the skid. ${ }^{77}$ This faulty design forced the operators to run the hoists twice as long, burning expensive fuel to compensate for the slip scrapers spillover.

\section{Bagley or Bottomless Scraper}

The Bagley or bottomless scraper is an open bottom scraper that functioned similarly to the slip scraper (see Figure 5.22). Like the slip scraper, the Bagley scrapper functioned as an excavation and transportation tool. The Bagley found employment in the deeper open-cut scraping operations. Along with the Bagley's bottomless composition it also has an ancillary apron located on its back that adds weight to the scraper lessening spill-over during transport. The apron on the rear of the Bagley scraper is attached to the front hoisting tackle and when operated lifts the rear of the scraper slightly off the ground, automating the digging process that required individual manpower with the slip scraper.

\footnotetext{
${ }^{77}$ Wimmler, Placer-Mining Methods and Costs in Alaska, 102.
} 


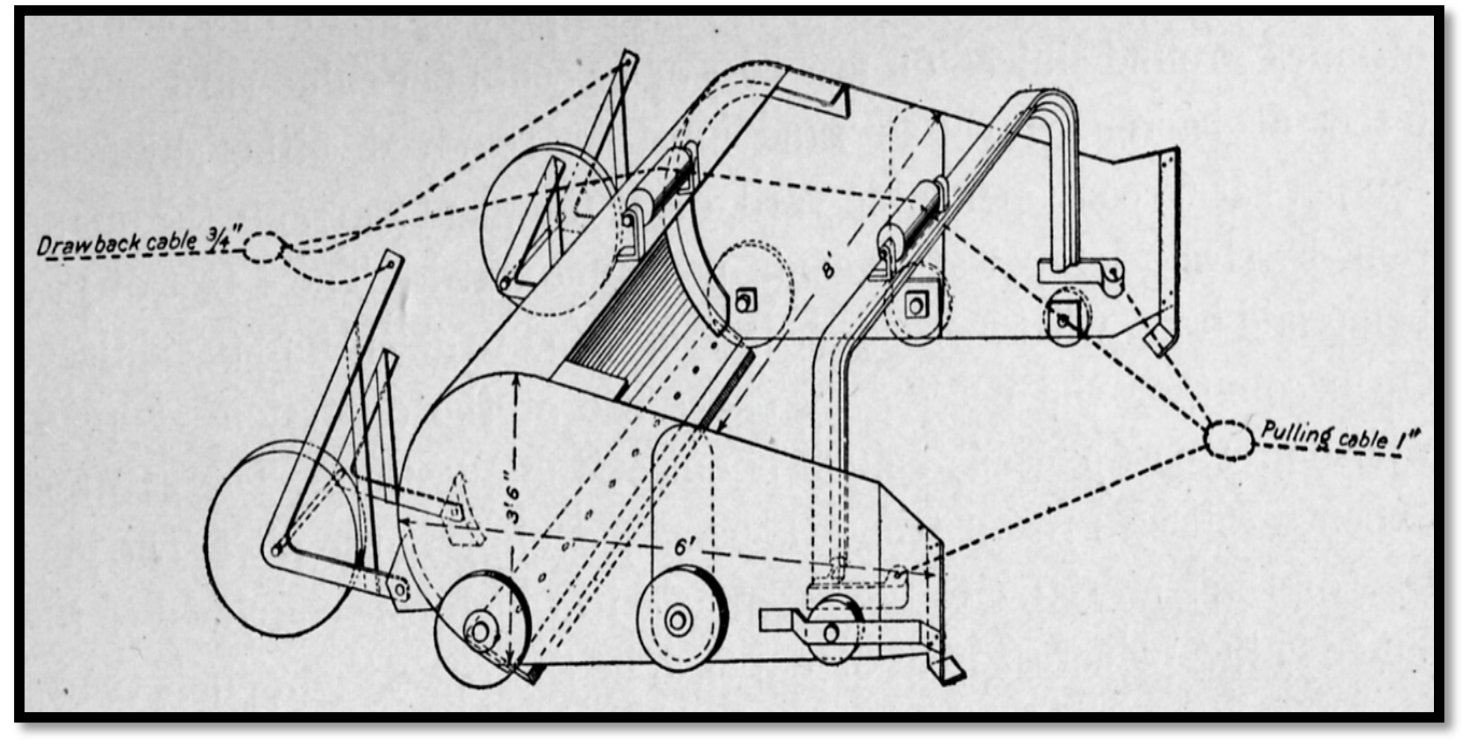

Figure 5.22: Bottomless Scraper, note rear apron and tackle arrangement (Purington 1905:65)

The Bagley scraper dumped its contents in different methods depending on the depth of the deposit. In shallower deposits the hoist pulled the Bagley towards a skid to a dump box and once at the dumping location the Bagley would be jerked backwards by the rear cable releasing the contents of the scraper. In the deeper deposits the Bagley would convey the material towards a dugout station containing a self-dumping car on tracks (see Figure 5.23). Once at the station the Bagley scraper is dumped in the same manner as the slip scraper, with the front of the Bagley scraper making contact with a timber and upended the scraper. ${ }^{78}$

\footnotetext{
${ }^{78}$ Wimmler, Placer-Mining Methods and Costs in Alaska, 97.
} 


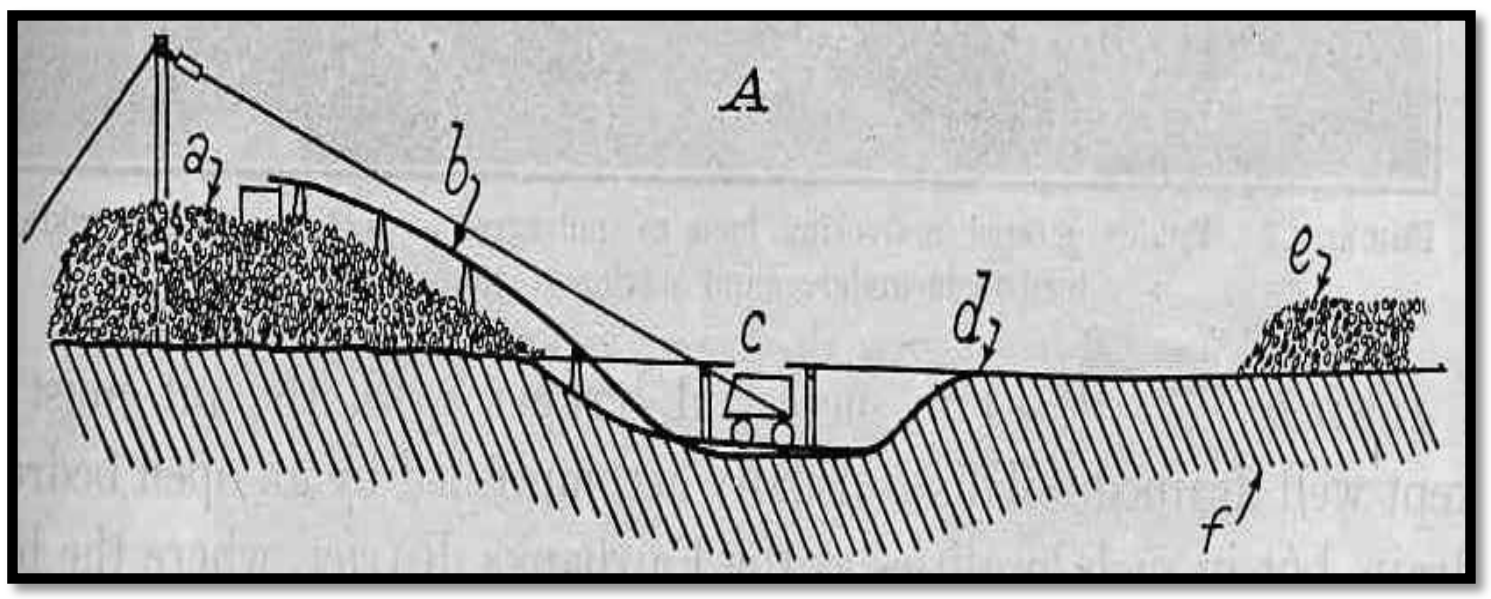

Figure 5.23: Elevation of scraper operation with car in station (Wimmler 1927:118)

Other industries utilized the Bagley scraper, most notably logging, railroading operations and underground coal mining, where the scraper ran through the drifts and delivered coal to the shaft stations. The capacity of Bagley scrapers used in interior Alaskan open-cut mining operations varied from 1.25 to 2.5 cubic yards, a smaller size than used in other mining operations where frozen gravels did not hinder larger capacity devices. The price of the scraper grew proportionately with the Bagley's size and accouterments. In 1928 the cost of a Bagley scraper in Alaska ranged from $\$ 375-\$ 525 .^{79}$ The teeth on the Bagley were chosen in regards to the composition of the alluvium being worked; knives, or extremely narrow teeth, were found suitable while working looser gravels, while heavy cast iron teeth found use in the more solidified alluvium.

\footnotetext{
${ }^{79}$ Wimmler, Placer-Mining Methods and Costs in Alaska, 97. Wimmler presents a chart on pg. 96 from a manufacturers catalog detailing the size, weight, price, type of engine required, etc. The chart also details if the Bagley is equipped with teeth or an apron, those without teeth or an apron cost significantly less.
} 


\section{Derrick Bucket}

Commonly found throughout Alaskan mining locations, the derrick bucket may be a product of reuse, often constructed out of used oil and fuel barrels (see Figure 5.24).

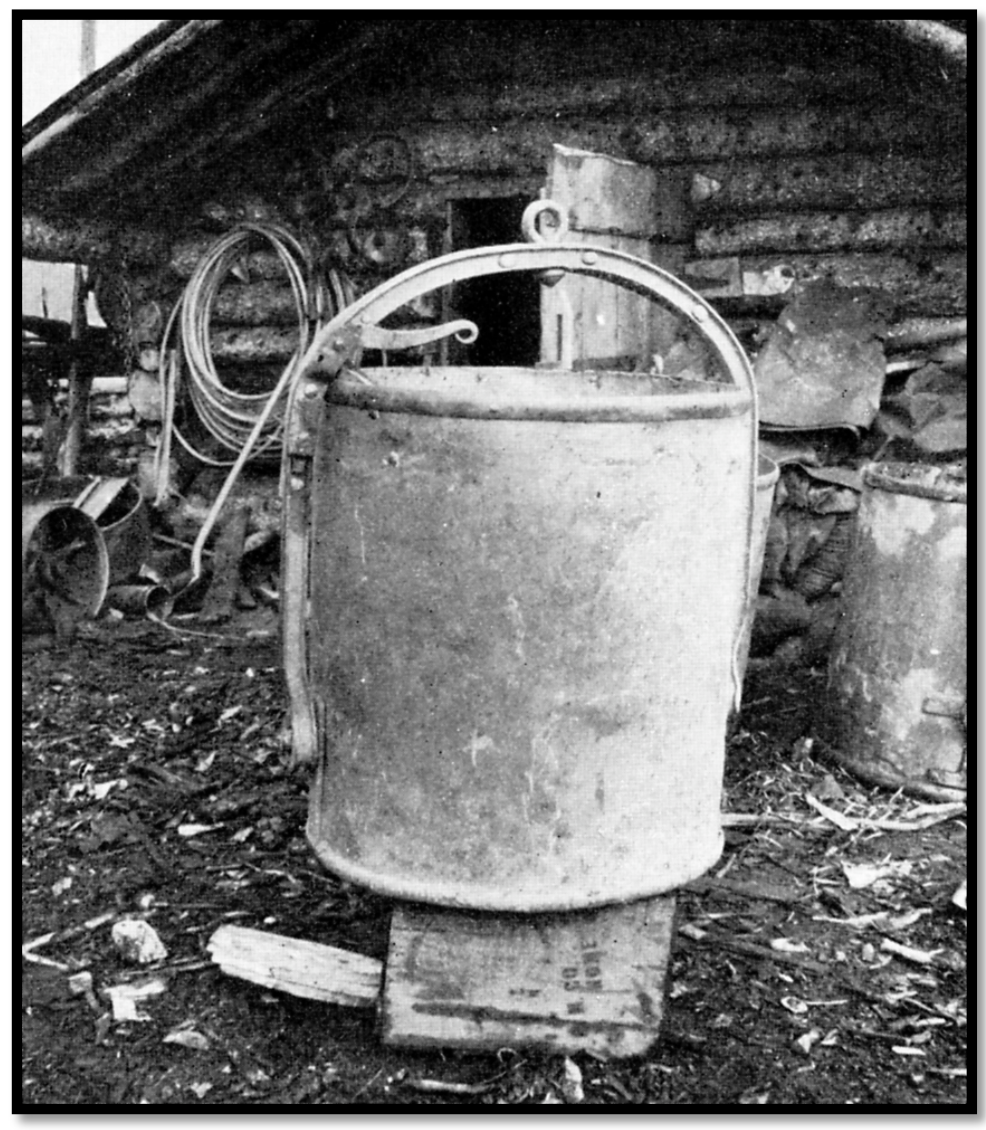

Figure 5.24: Derrick bucket with catch (Purington 1905: PL. XIII B)

These barrels are cut width-wise, creating a three-foot tall bucket with a two-anda-half-foot diameter opening. ${ }^{80}$ Two bolts affix a bale to the bucket, located roughly 8-10 inches from the bucket's bottom. The bale is the most elaborately designed feature on the bucket, consisting of a modified and reinforced hoop from the original fuel drum. A blacksmith bends the hoop into a u-shaped bale and rivets an eyebolt onto the apex of the bale, which is connected to the derrick

\footnotetext{
${ }^{80}$ Purington, Methods and Costs of Gravel and Placer Mining in Alaska, 68.
} 
system by a hook. A small catch is also riveted onto the side of the bale, projecting toward the inside of the bucket. ${ }^{81}$ The catch secures the bucket in an upright position until it reaches the dump box, where a worker releases the catch with a shovel, upending the bucket and dumping its contents. Although the buckets are of a fairly simple design, their cost was rather high; in 1905 they averaged around $\$ 25$ per bucket, which accounted for the cost of the original drum, blacksmith labor and fuel used to modify the bucket. ${ }^{82}$

\section{Dredging}

Traditional open-cut mining techniques, like scraping and derricking, were successful in exploiting the shallow high-grade deposits, yielding high profits for early miners in the Fairbanks district. The early miners who rushed into the area quickly exhausted these high-grade deposits, often with inefficient tools and techniques. With the highest-grade deposits exhausted, open-cut miners turned their attention to the plentiful low-grade deposits within and around the Fairbanks district. These miners attempted to turn a profit using the same traditional scrapers, but the cost of operating the plant coupled with inefficient washing plants proved to be economically unfavorable. Fairbanks miners knew that dredges could easily turn these low-grade deposits into profits for years to come; the problem lay in acquiring the dredges and actually getting them to the Fairbanks. The introduction of dredges into the Fairbanks area occurred in 1911, allowing the region to continue as a leader in placer gold production long after the highest-grade deposits were exhausted. I briefly described the dredging process in Chapter 2; this section will focus on the economic geology related to dredging in the Fairbanks Mining District.

\footnotetext{
${ }^{81}$ Purington, Methods and Costs of Gravel and Placer Mining in Alaska, 68.

${ }^{82}$ Purington, Methods and Costs of Gravel and Placer Mining in Alaska, 68.
} 
Bucket line dredges were introduced into the Fairbanks region fairly late, compared to the rest of Alaska, not appearing until 1911 on Fairbanks Creek, two years after the early placer mining boom years tapered off. ${ }^{83}$ Between 19091911 placer mining in the Fairbanks district experienced a cumulative drop of over 5 million dollars in total placer gold production, as the highest-grade bonanza strikes were exhausted and miners began turning their attention upstream to potential hard rock lode deposits. The presence of low-grade placers in the region was well known, but profitably extracting them was not an option due to the lack of high-capacity, efficient machines. The call for dredges in the area began much earlier, around 1905, when implementation of dredges in the Fortymile and Nome region brought successful results to their operators. Conditions similar to those of the Fortymile and Nome dredging areas were found in two regions around Fairbanks, specifically near Ester Dome to the west of Fairbanks and Pedro Dome located to the east.

Miners and geologists based in Fairbanks were well aware of the inefficient and wasteful practices conducted by small-scale mining operators and saw the potential in employing dredges in the area. The underlying problem in implementing dredges revolved around the limited and remote transportation system and a lack of men with capital ready to invest in the development of the area. ${ }^{84}$ However, investors and wealthy miners quickly converged in the Fairbanks region, forming nascent dredging companies, the first of which, The Lemons-Alaska, incorporated in 1910. The Lemons-Alaska dredging company had ambitious plans, taking out options on multiple creeks and seeking investors

\footnotetext{
${ }^{83}$ C.E. Ellsworth, "Placer Mining in the Fairbanks and Circle District", Mineral Resources of Alaska, Report on progress of investigations in 1911, USGS Bulletin 520-H (Washington: GPO, 1912) 240.

${ }^{84}$ Editorial Correspondence, The Engineering and Mining Journal, Vol. 80 (09-02-1905) 414.
} 
from as far away as London, sparking international interest in the Fairbanks region. ${ }^{85}$

The Alaska Exploration Co. constructed Fairbanks' first dredge in 1911, called the Fairbanks Gold No. 1. Located near Pedro Dome on Fairbanks Creek, the company shipped the dredge to Fairbanks from the Yukon Territory, where it operated on the Stewart River. ${ }^{86}$ The Stewart River flows northwest toward its junction with the Yukon River at Dawson. The dredge followed this watercourse from Dawson to Tanana and then onto Chena, where operators dismantled the 300-ton behemoth and loaded it onto train cars en route to the Gilmore Depot. At Gilmore, the dredge parts were unloaded from the train and repacked onto wagons that made the next leg of the trip to the "Number 8 Below" claim on Fairbanks Creek. On September 11, 1911, roughly three months after it left the Klondike for Fairbanks and costing an estimated $\$ 30,000$ in shipping, disassembling and reconstruction, the owners fired the dredge's steam powered engine and began digging. ${ }^{87}$

The Fairbanks Gold No. 1 was a Risdon dredge with a 1000 cubic yard capacity that ran on steam power and consisted of a 40-foot ladder comprised of 38 fairly small 3.5 cubic foot buckets. ${ }^{88}$ This dredge began its operation on the far eastern extent of Fairbanks Creek, just southeast of the settlement of Meehan. During its operation the dredge slowly moved downstream, excavating back and forth along the creek, generally moving towards the west. In 1918 the dredge resided on "Number 6 Above" on Fairbanks Creek near the western

\footnotetext{
${ }^{85}$ Mining News, "Lemons-Alaska", The Engineering and Mining Journal, Vol. 90 (12-17-1910) 1224. Lemons-Alaska quickly dissolved, however English backed dredge companies appeared on Fairbanks Creek soon after, referred to as "The English Company".

${ }^{86}$ Ellsworth, Placer Mining in the Fairbanks and Circle District, 242.

${ }^{87}$ Ellsworth, Placer Mining in the Fairbanks and Circle District, 242-243.

${ }^{88}$ Ellsworth, Placer Mining in the Fairbanks and Circle District, 242-243.
} 
extent of that paystreak. ${ }^{89}$ Around 1923, two, 75 horsepower Werkspoor Diesel engines replaced the wood fired boilers, increasing the horsepower of the dredge and its overall fuel efficiency. ${ }^{90}$ Ownership of the dredge followed the same pattern as the dredge's meandering movement around Fairbanks Creek, shifting from the Alaska Exploration Co to the Fairbanks Gold Mining Co. and finally the Fairbanks Gold Dredging Co. in a period of just over seven years. Although the results of the Fairbanks Gold No. 1 proved to be profitable, no other dredges appeared in the Fairbanks District until 1919.

In 1919 The Fairbanks Gold Dredging Co. constructed an additional higher-capacity, 4 cubic foot bucket line dredge on Fairbanks Creek, this time on the "Number 1 Below" claim. ${ }^{91}$ This dredge, the Fairbanks Gold No. 2, was located on a separate paystreak west of the original dredge and similarly worked its way downstream. The Fairbanks Gold No. 2 had a daily capacity of 2500 cubic yards, 1.5 times more than the first dredge in Fairbanks. Constructed by San Francisco's Union Construction Company and consisting of a ladder with 79 buckets, more than twice the amount on the Fairbanks Gold No. 1. Two, 120 horsepower Scandia-Pacific semi-diesel engines powered the Fairbanks Gold No. 2. The introduction of the technologically advanced Fairbanks Gold No. 2 denoted the development of Fairbanks from a fledgling small-scale dredging district to a growing one. ${ }^{92}$ By 1920 a total of 30 men were employed on these two dredges, with that number soon growing significantly.

\footnotetext{
${ }^{89}$ Thomas J. Riggs, "Report of the Governor of Alaska", Reports of the Department of the Interior, For the Fiscal Year Ended June 30 1919, Vol. II, (Washington: GPO, 1920) 422.

${ }^{90}$ B.D. Stewart, Annual Report of the Territorial Mine Inspector to the Governor of Alaska, 1923 (Juneau: Alaska Daily Empire Print, 1924) 38.

${ }^{91}$ Alfred Brooks, "Mineral Resources of Alaska, Report on Progress of Investigations in 1920", USGS Bulletin 722 (Washington: GPO, 1922) 44.

${ }^{92}$ B.D. Stewart, Annual Report of the Territorial Mine Inspector to the Governor of Alaska, 1920 (Juneau: Alaska Daily Empire Print, 1921) 30.
} 
Around the same time as the installation of the Fairbanks Gold No. 2, interest in developing parts of Cleary Creek for dredging became heightened and in 1924 the Chatham Gold Dredging Co. installed the third dredge in the Fairbanks district. Although all three dredges in Fairbanks were of the bucket line type, the Cleary Creek dredge dealt with tailings in a different manner, sending them astern through a flume. The two original dredges utilized an elevated conveyor that stacks the tailings astern of the dredge. The Cleary Creek dredge was the smallest capacity dredge in the area; constructed or built for the Alaskan "Nome Creek Dredging Company", the Cleary Creek dredge consisted of 60 buckets with 1.5 cubic foot capacity powered by two, 32 horsepower Delmon tractor gasoline engines with a daily capacity of around 1000 cubic yards. ${ }^{93}$ Two years later in 1926, the Tanana Valley Gold Dredging Co. constructed a fourth dredge in the Fairbanks region on Fish Creek.

Also in 1924, two of the larger companies invested in dredging in Alaska, the Hammon Consolidated Gold Fields and the United States Smelting, Refining and Mining Company (USSR\&M), consolidated their efforts into a single company known as the Fairbanks Exploration Company (FEC). ${ }^{94}$ Hammon Consolidated operated dredges in Nome and had holdings on claims in Western Alaska while the USSR\&M controlled numerous holdings on claims in the Fairbanks district. Combining these two companies spawned the largest dredge operator in Alaska and eventually changed the face of Alaskan placer mining. During the three years following its 1924 creation, the FEC focused its attention in the Fairbanks region conducting exploratory work, preparing its holdings for large-scale dredging. The FEC also began developing the 90-mile Davidson

\footnotetext{
${ }^{93}$ Wimmler, Placer-Mining Methods and Costs in Alaska, 102, 178-181.

${ }^{94}$ Phillip S. Smith, "Mineral Resources of Alaska, Report on Progress of Investigations in 1924", USGS Bulletin 783 (Washington: GPO, 1926) 11.
} 
Ditch, tapping into the headwaters of the Chatanika Creek and supplying the region with an adequate water supply for the company's ambitious proposals.

Preparing virgin ground for dredging required extensive development work, taking up to three years time to bring water into the area, strip the overburden and thaw the surface. ${ }^{95}$ The FEC used churn drills for prospecting. Churn drills removed six-inch cores from the frozen gravels that provided the company with information regarding the amount of overburden, composition of the frozen gravel and the grade and depth of the auriferous deposit. ${ }^{96}$

The full extent of the FEC's dredging operation became evident in 1927 when they finished construction of a large powerhouse creating electricity for the dredging operation. In 1927 the FEC also began receiving the disassembled parts of their first large dredges, scheduled to go into operation the following year. The first two dredges installed by the FEC were located near Pedro Dome on Goldstream Creek and on Cleary Creek near its junction with Chatanika Creek. These two dredges contained buckets with a capacity more than double that of the Fairbanks Gold No. 2, able to carry 10 cubic feet per bucket. ${ }^{97}$ In addition to the greater capacity bucket line, the dredges constructed by the FEC were built like tanks, constructed with materials usually reserved for dredges twice their size, fashioned in this manner to withstand the harsh conditions in Alaska. These two dredges went into operation in 1928, along with an additional smaller dredge built by the FEC on Gilmore Creek, leading to an increase in the yearly placer gold production for the Fairbanks region. In 1929 the annual placer gold output from Fairbanks increased by nearly $\$ 200,000$ from the previous

\footnotetext{
${ }^{95}$ Philip S. Smith, "Mineral Resources of Alaska, Report on progress of investigations, 1935", USGS Bulletin 880 (Washington: GPO, 1937) 40.

${ }^{96}$ John C. Boswell, History of the United States Smelting, Refining and Mining Company (Fairbanks: Mineral Industries Research Laboratory, UAF, 1979) 15.

${ }^{97}$ Philip S. Smith, "Mineral Resources of Alaska, 1927", USGS Bulletin 810 (Washington: GPO, 1930) 25.
} 
year's total and the dredge became the predominant producer for placer mining in Alaska, surmounting all other techniques and accounting for $71 \%$ of the total state yield. ${ }^{98}$ FEC constructed two additional dredges in 1929, giving them a total of five operating dredges in Fairbanks and upping the total number of operating dredges in Fairbanks to eight.

The FEC remained the primary dredge operator and placer gold producer in Fairbanks, along with becoming one of the largest employers, with over 500 men on their Fairbanks payroll in $1932 .{ }^{99}$ In 1932 , the FEC only operated in the Pedro Dome area, but in 1933 the company expanded their holdings to include some of the low-grade placers near Ester Dome. Along with the normal prospecting and development undertaken in virgin dredging grounds, the FEC also needed to supply the Ester Dome area with an adequate water supply for thawing. This need for water led to the construction ditches, pipes, flumes and a pump house that brought water to the Ester placers from the Chena Slough. In 1933, the FEC officially became recognized as the USSR\&MC Fairbanks Exploration Department, a name that would more or less stick with the operation for the next 30 years. Near the end of the 1936 season the dredge on Goldstream Creek had worked-out the low-grade deposit and the USSR\&MC disassembled the dredge and shipped it to the company's Ester holdings. ${ }^{100}$ In 1937, the dredge at Ester began operating and the USSR\&MC became the only active dredge operator in the Fairbanks region, buying out the Tanana Valley Gold Dredging Co.'s holdings and equipment on Fish Creek, creating a relative dredging monopoly in the district.

\footnotetext{
${ }^{98}$ Philip S. Smith, "Mineral Resources of Alaska, 1929", USGS Bulletin 824 (Washington: GPO, 1932) 32

${ }^{99}$ B.D. Stewart, Mining Investigations and Mine Inspection in Alaska, Including assistance to prospectors for the biennium ending March 31, 1933 (Juneau, Territorial Printing Press, 1934) 97. ${ }^{100}$ Phillip S. Smith, "Mineral Resources of Alaska, Report on Progress of Investigations 1936", USGS Bulletin 897 (Washington: GPO, 1938) 46.
} 
Prior to large scale dredging in the Fairbanks district, the region saw a progressive decline in placer production moving from a high of nearly $\$ 10$ million in 1909 to a low of $\$ 350,000$ in 1927 . The FEC's introduction of large modern dredges into the Fairbanks area revitalized the district's reputation as a leader in placer gold mining. The FEC/USSR\&MC also significantly contributed to the local economy of Fairbanks, adding between 400-600 jobs per season and over $\$ 50$ million in total payroll from 1926-1959. ${ }^{101}$ Dredging operations ceased in the Fairbanks district in the early 1960 s with the most valuable deposits becoming exhausted and the remaining holdings of the USSR\&MC being sold off, as the land held more value in real estate than auriferous material. Although the USSR\&MC abandoned dredging nearly 50 years ago, their immense undertaking remain evident today. Although many of the landscape features have become overgrown, signs of dredging remain; isolated features like broken trommel screens and equipment, linear features like ditches, roads and power lines and landscape features resembling giant worm castings, surround the Pedro Dome and Ester Dome regions. Three of the original dredges, now overgrown and idle, remain in the Fairbanks area, reminding visitors of the district's intense industrial past. It is clear that without the introduction of dredges into the Fairbanks Mining district and the formation of the FEC/USSR\&MC placer mining in the Fairbanks region would have dwindled to the point of obscurity 40 years prior to the last dredge settling in a pond and forever dropping its spud and stacker.

\footnotetext{
${ }^{101}$ Boswell, History of Alaskan Operations, ix.
} 
"The extensive but not remarkably rich gold-bearing areas of Alaska offers a field for men who propose to conduct their operations with energy, intelligence and economy. To others it can afford only ultimate poverty and despair." Methods and Costs of Gravel and Placer Mining in Alaska, Chester Wells Purington

\section{Chapter 6: The Placer Mining Landscape}

The primary objective of placer mining is reaching the bedrock floor of the placer deposit and exposing the displaced gold that settled there. The Fairbanks Mining District underwent three phases of placer mining, each phase seeing new technologies and improved mining methods applied to environmental challenges. Each phase created distinctive patterns on the landscape that reveal the historic mining trends in the district. The first phase of mining, the drift mining period, dominated the mining boom of 1903-1909. The drift mining phase utilized earlier, lower capacity technologies and had the least impact on the landscape compared to the other phases of mining. The second phase, the open-cut period, was defined by a period of technological maturation; the initial smaller capacity technologies used during the mining boom period were replaced with larger capacity technologies as mining methods progressed, creating the most widespread impact on the landscape. The third phase, the dredging period, revived the Fairbanks district by reworking some of the areas that were overlooked or ineffectively mined during the initial stampede. The dredging period created a distinct recycled landscape in the creek beds and reinvented the Fairbanks district as a top placer producer after years of decline.

Unlike other placer mining districts in Alaska, the Fairbanks district lacks the typical characteristics that often dominate a placer mining landscape. Missing are the rows of hand-stacked tailings and hoodoo ${ }^{1}$ like formations

\footnotetext{
${ }^{1}$ Hoodoos, most often associated with the awesome geologic formations of Bryce Canyon in Utah, are tall rock pillars created through erosional processes.
} 
created from intense hydraulicking along the face of a bench. Instead, the Fairbanks placer mining district, like many mining districts, is dominated by a succession of technology and landscape rework, where many of the older features have been obliterated as the miners attempted to make a profit by rewashing the tailings and overburden piles from the first mines in the area. Fortunately, pockets of early development work were left untouched by the new technologies, preserving fragments of the landscape characteristic to all three phases.

During the summer of 2011 and 2012, archaeological field crews from Michigan Technological University and the University of Alaska-Anchorage conducted archaeological investigations within historic mining claims in the Fairbanks Mining District. During the investigations, field crews recorded cultural features on the mining landscape, ranging from prospect pits and ditches to stamp mills and adits. Beginning in 1909, placer mining and lode mining overlapped in the Fairbanks district and this co-occurrence is evident in the mining features that the field crews recorded. The archaeological investigation of 2012 was focused largely in lode mining claims, compared to the surveys of 2011 that were spent predominantly in placer mining claims. Since the focus of the 2011 surveys were generally in historic placer mining locations these are the data that will be analyzed in this chapter. 


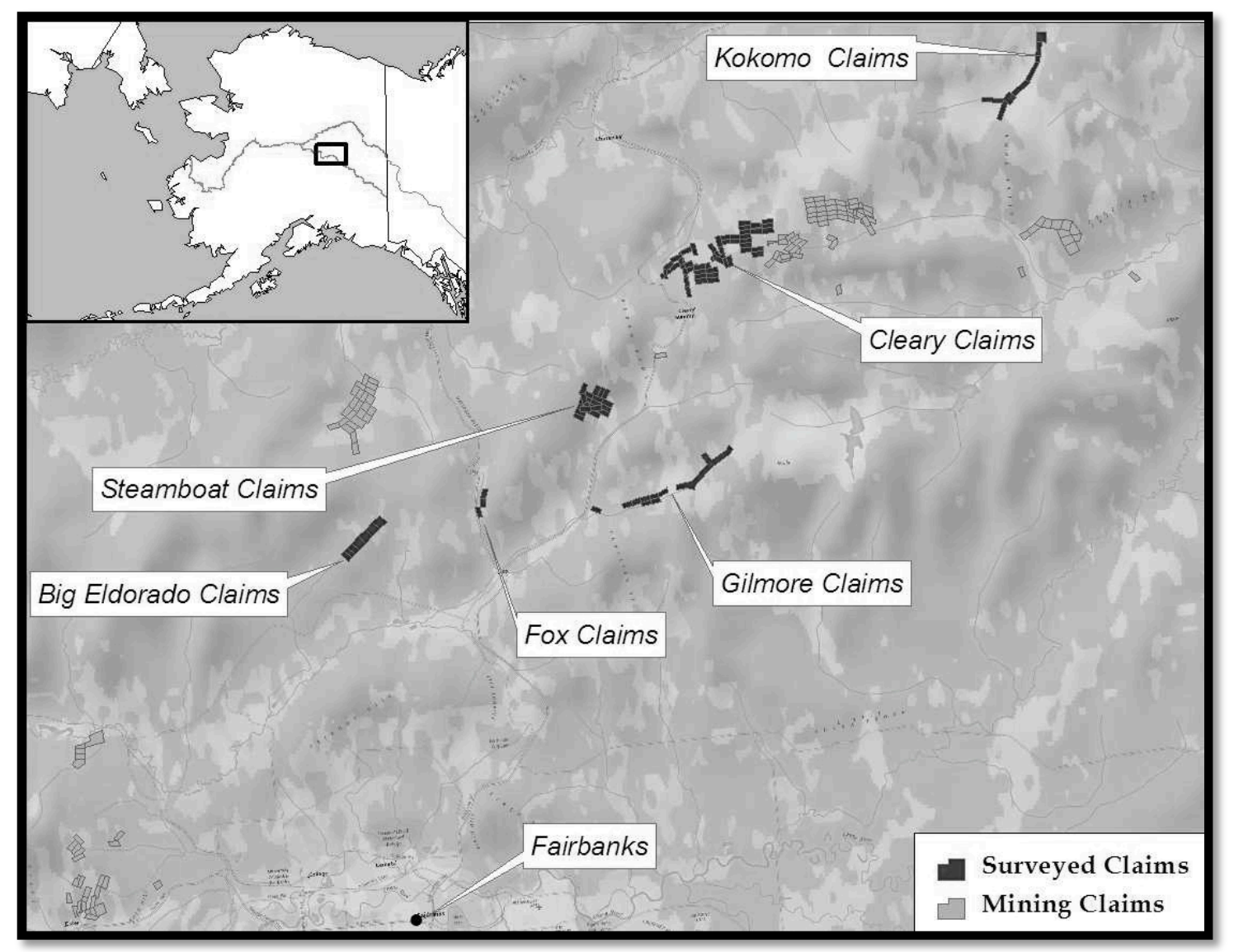

Figure 6.1: Overview of Claims in the Fairbanks District.

In 2011, roughly 1200 cultural features were recorded in the Fairbanks Mining District. These cultural features were found in six historic placer mining locations in the Pedro Dome area, specifically: Big Eldorado Creek, the Cleary Creek area (Bedrock, Chatham and Wolf Creeks), Fox Creek, Gilmore Creek, Kokomo Creek, and Steamboat Creek (see Figure 6.1). These cultural features were analyzed and grouped into roughly 60 sites, defined by the feature's typology, spatial extent and approximate age. Of these site clusters, I have selected the three that show surface characteristics distinctive to the mining landscapes of the three phases of mining in Fairbanks. These sites will be described below in the overview of each mining phase. 


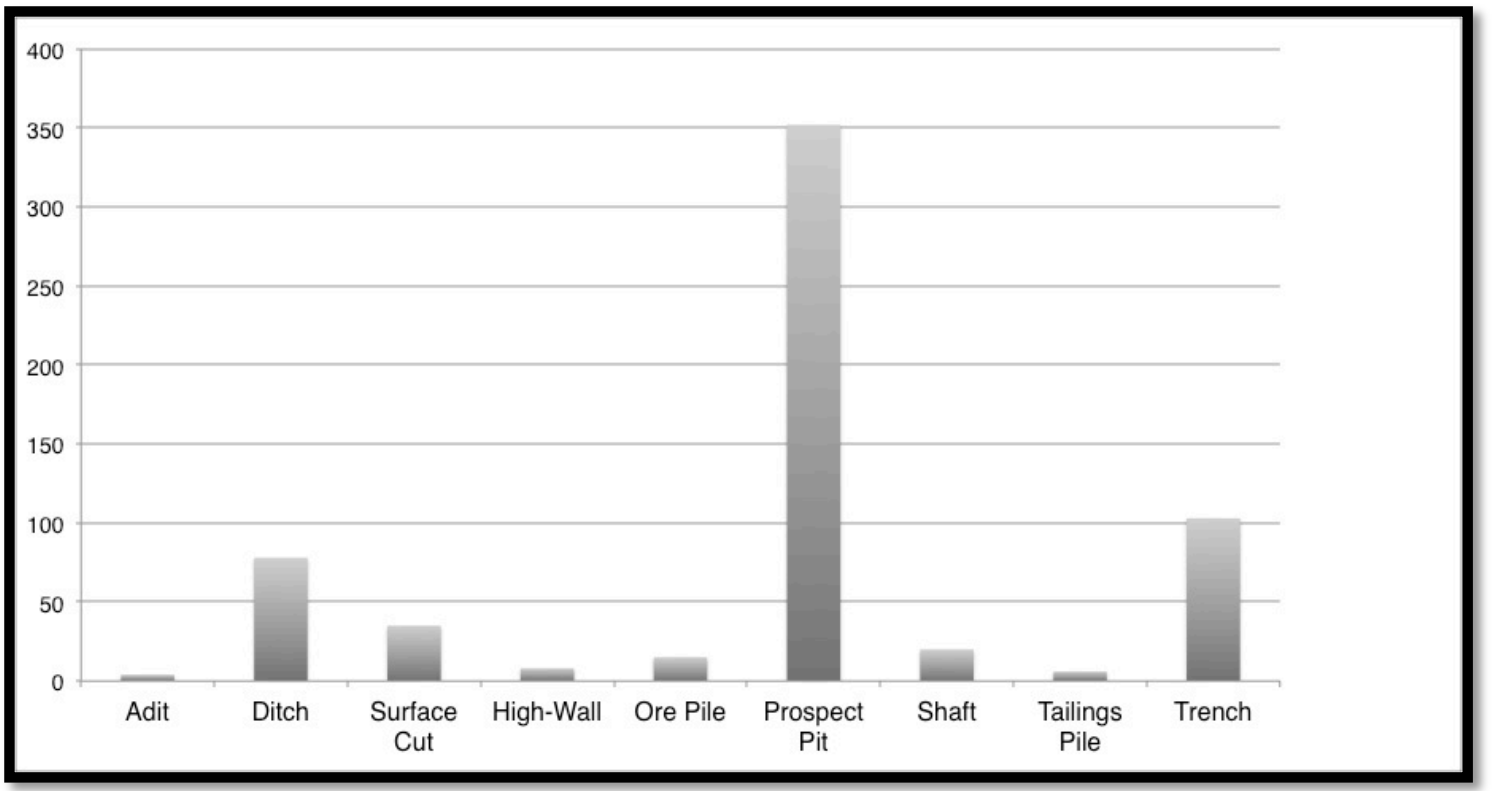

Figure 6.2: Landscape features recorded in 2011, note the abundance of prospecting features and ditches.

Although certain landscape patterns are distinct to a specific form of mining, the two most prominent landscape features in the Fairbanks district, the infrastructure created for water acquisition and prospect pits, co-occur among the three phrases (see Figure 6.2). The need for water, as both a washing and thawing agent, dominated all aspects of placer mining in the Fairbanks district, and this need is reflected in the landscape's intricate system of ditches, mentioned earlier in Chapter 3. Coupled with ditches, the remnants of prospecting are found in surface features consisting of a variety of pits and small linear cuts. Vegetative patterns emerge in these development features. Thriving in these old cuts, pits, pushes and ditches are dense patches of willows and alders that can serve almost as a predictive model for potential historic mining features (see Figure 6.3). 


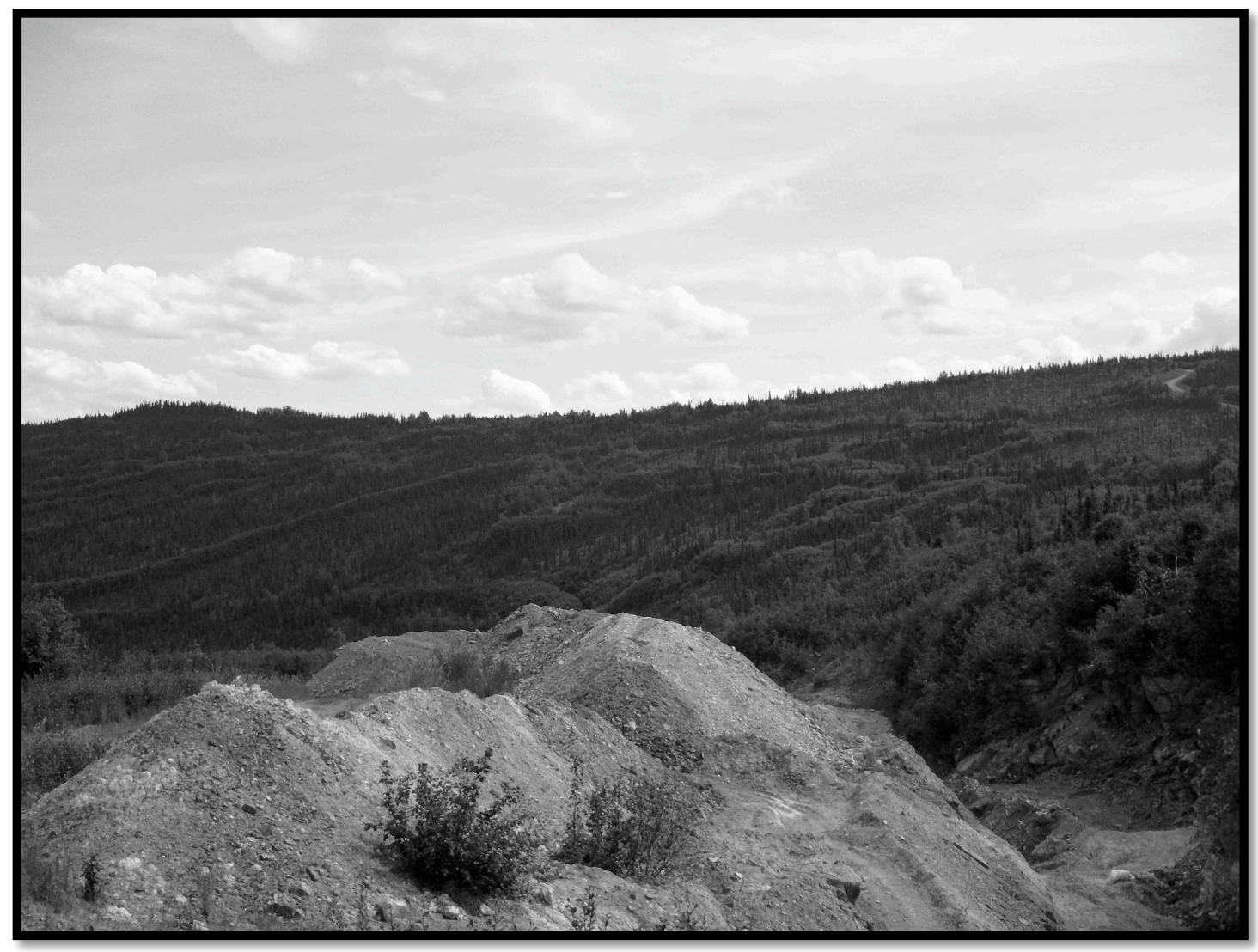

Figure 6.3: Modern open-cut landscape in foreground with historic workings in background marked by linear vegetation patterns. (Baeten: 2011)

This chapter will compare the three mining trends and their associated landscapes found in the Fairbanks district, starting with drift mining, followed by open-cut and concluding with dredging.

\section{Phase 1: Drift Mining}

The discovery of gold within a previously unexplored region often creates a stampede of speculators, miners and prospectors. The stampede period often commences with prospectors haphazardly searching for the highest-grade deposits that will yield them the greatest profit. In Fairbanks the highest-grade placer deposits were found within relatively old creek placers. These old creek placers contained the richest alluvium in the district and became the focus of the 
initial stampede. The initial mining technique used in many of the deep placers was unsystematic gophering, a technique that held little regard for efficiency or longevity. ${ }^{2}$ The majority of miners soon abandoned this method and systematic drift mining became the preferred technique, but the inefficient gophering of the stampede years would be reexamined later.

To reach the valuable material, the placer miners had two options: either using traditional open-cut techniques such as stripping the overburden off in layers through scraping and ground sluicing until they hit bedrock or by using the drift mining method of sinking a shaft directly to the paydirt. The first method required processing an exorbitant amount of worthless overburden, while the second option often required the construction of an extensive underground infrastructure to support the mine workings. Since the highest-grade deposits were found at extreme depths, the drift mining technique became the primary method used in the initial phase of placer mining in the Fairbanks region.

Compared to the other phases of placer mining in Fairbanks, the drift mining period created the smallest visual footprint on the landscape, owing in part to the employment of smaller capacity technologies along with the underground nature of extraction. While the visual effect of drift mining on the landscape is minimal, the actual impact of drift mining had on the region was extensive. Drift mining was the primary mining method for nearly the first 30 years of mining in the Fairbanks region. Early reports from the district claim that a miner could walk nearly three miles underground through the drifts from Cleary City to Chatanika. ${ }^{3}$

Drift mining created temporary landscapes. Drift mining landscapes were built up during the winter with miners accumulating large winter dumps of

\footnotetext{
2 Robert Peele, The Mining Engineers' Handbook (New York: John Wiley and Sons, 1927) 546.

${ }^{3}$ Dermot Cole, "Fairbanks, A Gold Rush Town that Beat the Odds", City History Series (Epicenter Press: Fairbanks-Seattle, 1999) 40.
} 
alluvium, and they were subsequently taken down the following summer as miners washed the alluvium away from the mine (see Figure 6.4). Many of the features typical in drift mining have become indistinct, blending in with the prospecting features found throughout the Fairbanks mining landscape. The typical surface arraignment of a drift mine in the Fairbanks region consisted of a cribbed shaft with collar, head-frame, boiler or engine house, hoist, gin pole, carrier and tackle. ${ }^{4}$ Most of these surface features are not entirely unique to drift mining; they also found use in simple prospecting and open-cut mining arrangements, but when these components are found together they undoubtedly signify a drift mining site.

\footnotetext{
${ }^{4}$ Chester Wells Purington, "Methods and Costs of Gravel and Placer Mining in Alaska", USGS Bulletin 263 (Washington:GPO, 1905) 82. On page 82, Purington includes a diagram of the typical surface arrangement of a small drift mine.
} 


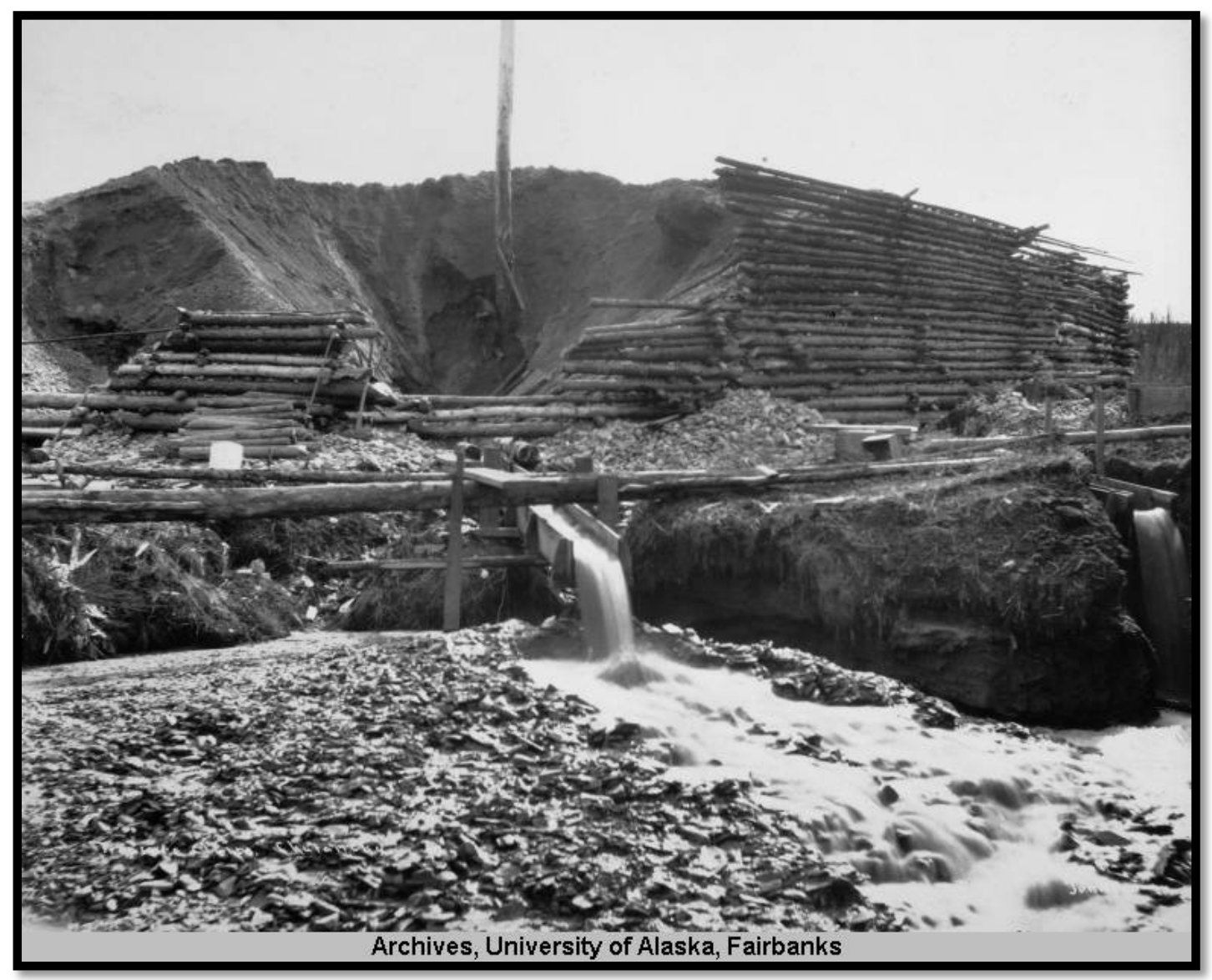

Figure 6.4: Washing a winter dump (Courtesy of University of Alaska Fairbanks, Alaska and Polar Regions Collection, Albert Jobnson Collection, Accession \#UAF-1989-166-22)

Many components of a typical drift mine deteriorate; specifically, the headframe, collar, and cribbing, often leaving the void of the shaft and various mechanical components as the only remaining surface features of a drift mine (see Figure 6.5). Equipment found in the surface arrangement of a drift mine can help characterize the drift mining landscape from open-cut mining arrangements, but the majority of equipment used found employment in both forms of placer mining (see Table 6.1). ${ }^{5}$

\footnotetext{
${ }^{5}$ In The Chisana-Gold Hill Landscape CLR, the author refers to an unpublished draft report by Logan Hovis in which he states, "Hoisting equipment, either hand or mechanical, is the best
} 


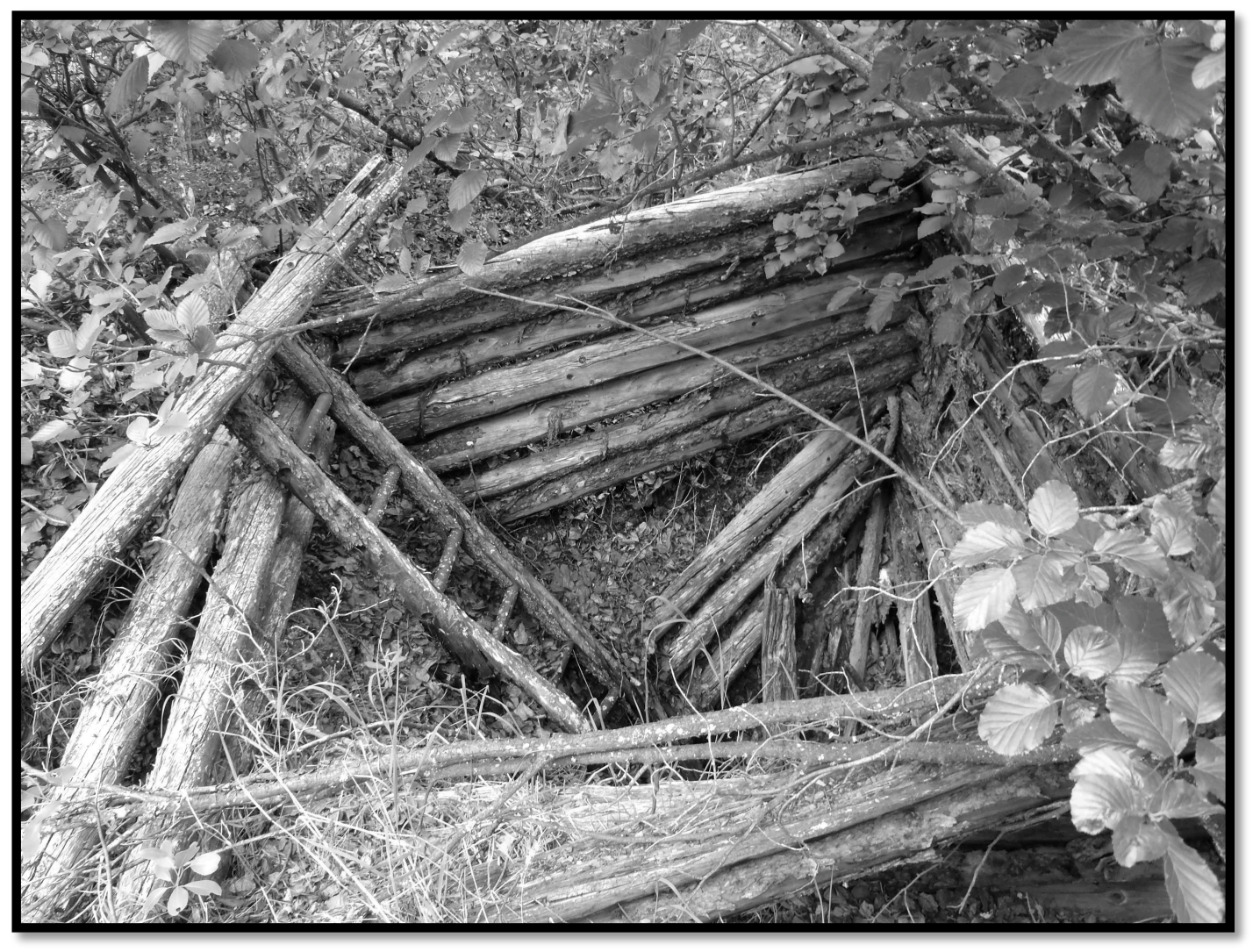

Figure 6.5: Cribbed shaft and ladder (Lassiter: 2011)

physical indicator". While hoists predominately found employment at placer miners engaged in drifting, they also were found at open-cut mines, specifically ones utilizing derricking and steam scraping. Winches, which played an important role in most open-cut mining activity, can be easily mistaken for a hoist, making the hoist a probable indicator but not a definitive indicator of a drift mine. Ore buckets seem to have found primary application in drifting operations, making their presence a more indicative sign of a drift mining operation. 
Table 6.1: Equipment used in the Fairbanks placer mines

\begin{tabular}{|c|c|c|}
\hline Equipment & Drift Mine & Open-Cut Mine \\
\hline Boiler & $\mathrm{X}$ & $\mathrm{X}$ \\
\hline Hoist & $\mathrm{X}$ & $\mathrm{X}$ \\
\hline Self Dumping Carrier & $\mathrm{X}$ & $\mathrm{X}$ \\
\hline Steam Points & $\mathrm{X}$ & $\mathrm{X}$ \\
\hline Ore Bucker & $\mathrm{X}$ & $\mathrm{X}$ \\
\hline Sluice Boxes & $\mathrm{X}$ & $\mathrm{X}$ \\
\hline Boomer Dams & $\mathrm{X}$ & $\mathrm{X}$ \\
\hline Ore Buckets & & \\
\hline Scrapers & $\mathrm{X}$ & $\mathrm{X}$ \\
\hline Gin Pole & & \\
\hline Headframes & & \\
\hline
\end{tabular}

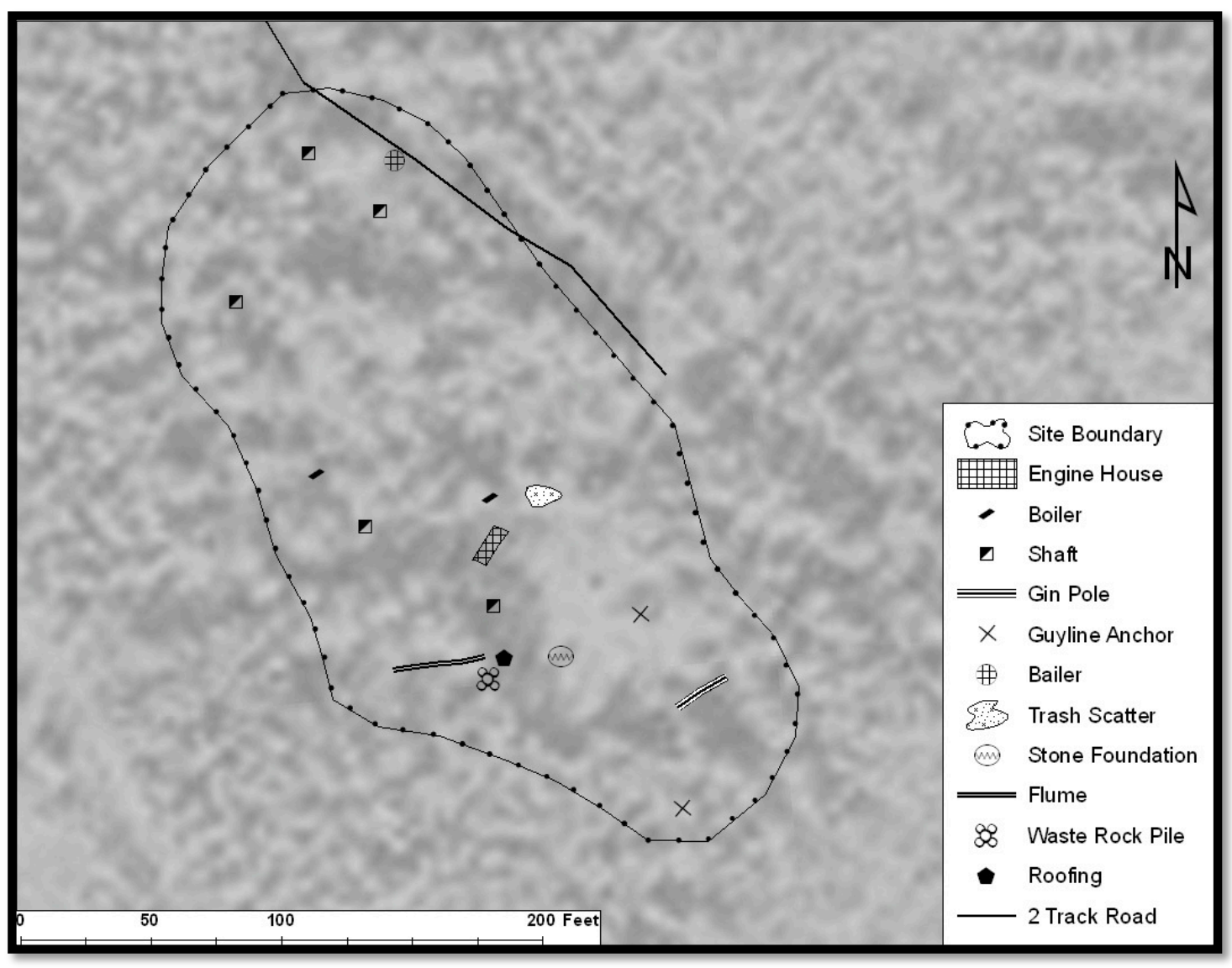

Figure 6.6: Chatham Creek Drift Mine Site (Baeten: 2012) 


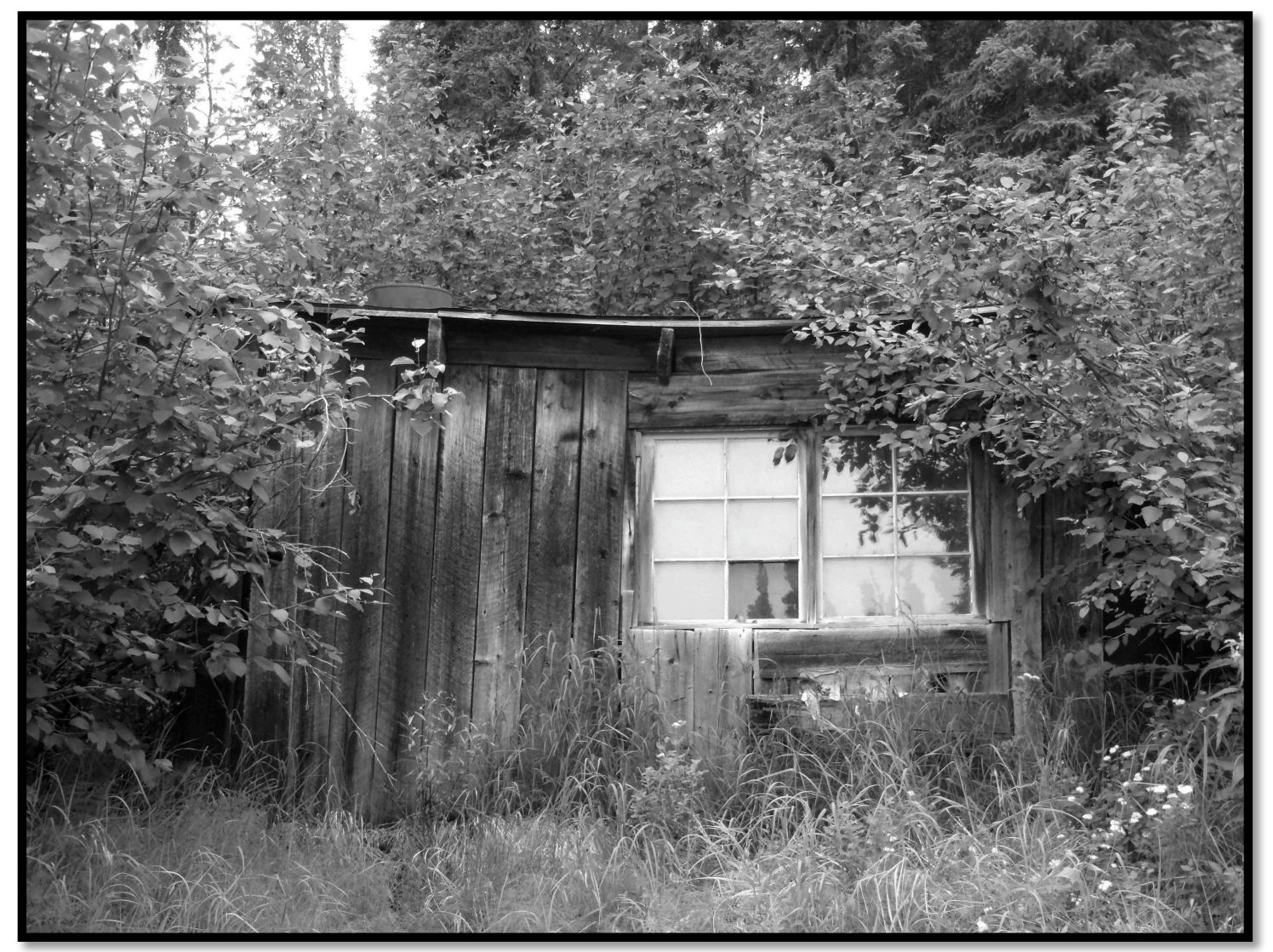

Figure 6.7: Chatham Creek Site Engine House (Baeten: 2011)

A particularly well-preserved drift mining site was located near the confluence of Tamarack Creek and Chatham Creek in the Pedro Dome region (see Figure 6.6). This site contains a surface arrangement nearly identical to the historic diagram pictured in Figure 32. The core of the site is an engine house that contains a hoist, diesel engine and the foundation for a vertical boiler (see Figure 6.7). The hoist and engine are located in the southeast corner of the engine house, situated in front of a window and small canvas covered opening in the southern wall. The hoisting cable ran through this canvas covered opening on its way to the main shaft, located just south of the engine house (an additional four shafts are located in the site boundary). The main shaft fits the description of a shaft found in a Fairbanks drift mining site, being cribbed with spruce poles and measuring roughly 6 feet $\times 6$ feet (see Figure 6.8). 


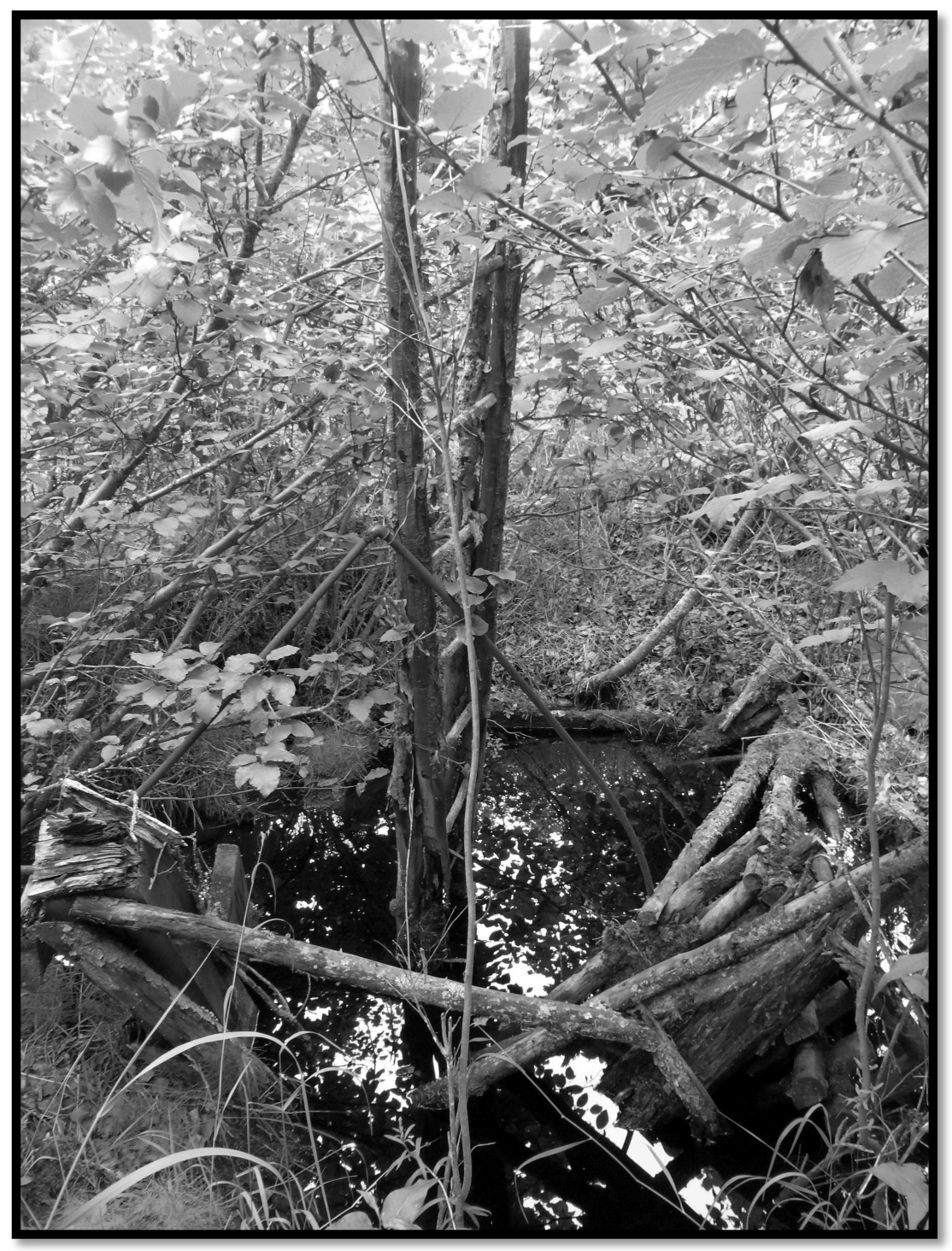

Figure 6.8: Cribbed Shaft (Baeten: 2011)

Within the shaft is a hand built ladder along with piping used for steam thawing that is running into the flooded pit. Immediately adjacent to the shaft is a small pile of corrugated iron that was likely used for roofing above the shaft during its operating years. Immediately south of the main shaft and wedged between two trees is the remains of a flume or a sluice. The flume runs generally east-west and was used to either wash the waste material away from the mine, 
or to collect the paydirt removed from the shaft. A small waste rock pile is found adjacent and to the south of the eastern end of the flume.

A collapsed gin pole is located in the southeast corner of the site, just to the east of the flume or sluice, and is accompanied by two sets of braided cable, located around the gin pole's circumference (see Figure 6.9). The gin pole is roughly ten inches in diameter and fell in a generally east-west orientation. Pieces of braided cable remain attached to the pole's eastern end, suggesting that the eastern end of the pole is its top, and that the pole fell to the east. The two sets of braided cable acted as anchors, or guylines, for the gin pole during its operation. The northernmost braided cable arrangement is attached at its end to a steam point, which was used as an anchor for the setup, driven into the ground much like a tent stake. This reuse of equipment is a pattern typically seen in mining locations, especially in remote locations like Fairbanks. 


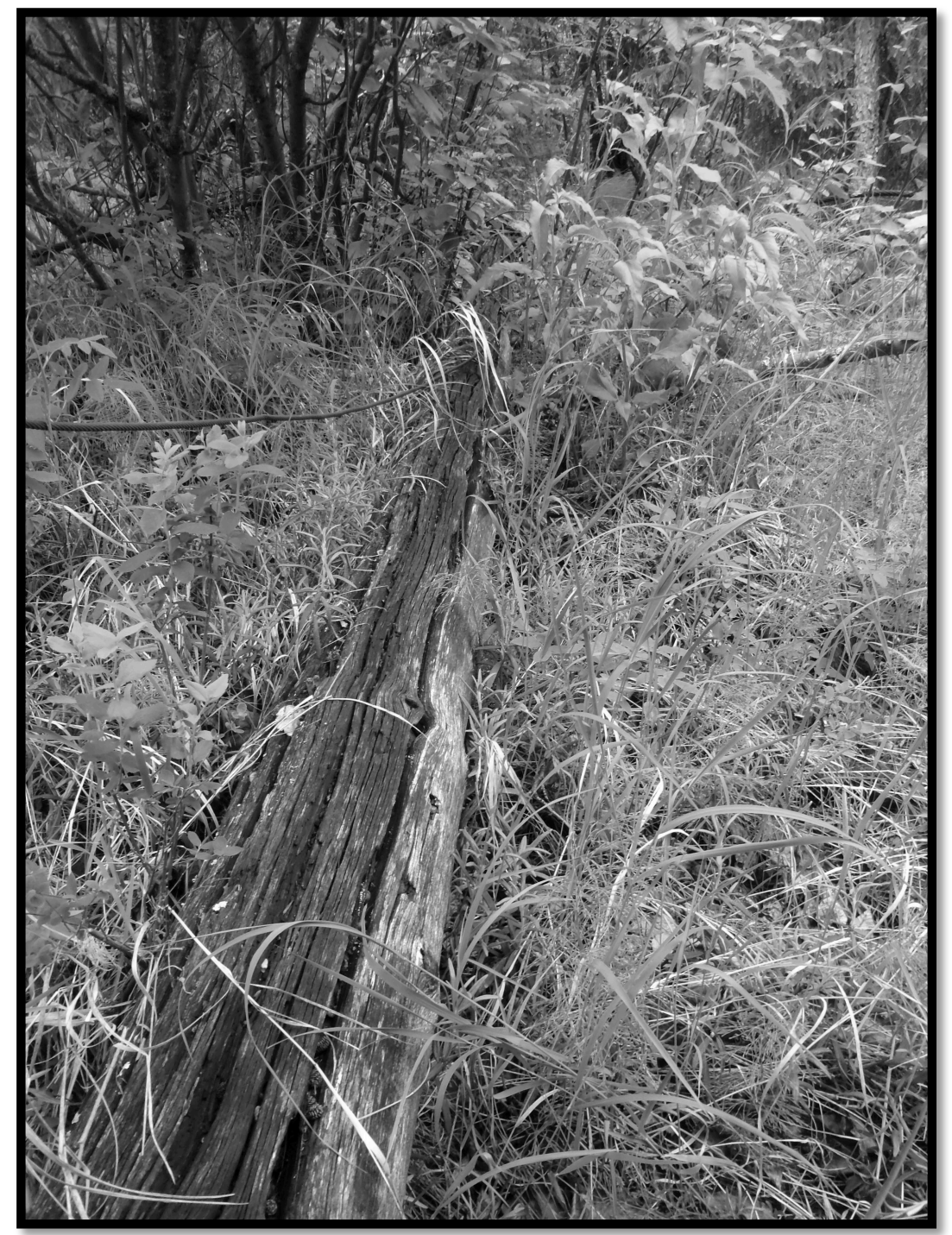

Figure 6.9: Collapsed Gin pole (Baeten: 2011)

In addition to the surface arrangement of the primary development area, additional features related to the drift mining operation are located around the site. West of the engine house is another water-filled, cribbed shaft and an additional larger vertical boiler. This area is likely the remains of an earlier mine development within the site, used prior to the development work of the site's main core, where miners felt the need to construct an engine house to shelter a diesel engine. In the northern most extent of the site, three additional water-filled shafts 
are located. These three shafts lack the cribbing seen in the two more developed shafts and may have functioned more as prospecting shafts than developed mine workings. Also located in the northern extent of the site is a bailer, modified from a 55-gallon fuel barrel (see Figure 6.10).

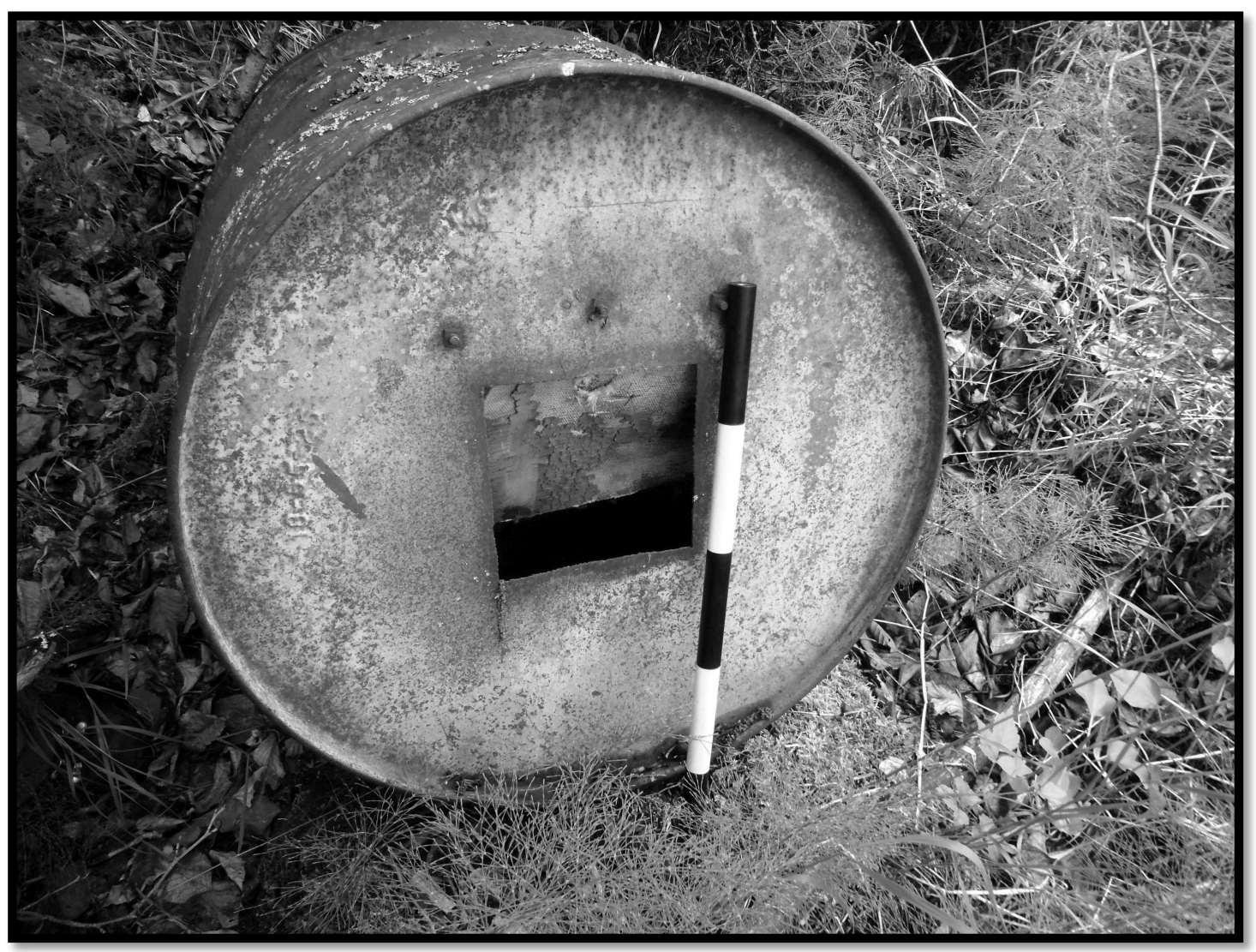

Figure 6.10: Modified fuel drum bailer (Baeten: 2011)

Miners cut a hole into the base of a 55-gallon drum and within the inside of the barrel they attached a heavy piece of canvas on top of one side of the perimeter of the hole, creating a flap. On the open side of the barrel, miners attached a heavy handle, similar to those seen in ore buckets. Miners lowered the bailer into the flooded shafts during the thawing months. As the bailer was lowered, water would push up the canvas flap and fill the bailer. Once the bailer was full it would be hoisted out of the shaft, with the water inside forcing the canvas flap back down against the interior of the bail. The bailer shows further 
reuse at the mine and adds to the distinctive landscape seen in the initial phase of mining in Fairbanks.

\section{Phase 2: Open-Cut Mining}

After the richest deep placers in the Fairbanks region were exhausted, miners turned their attention to the more accessible and unfrozen lower grade placer deposits. These shallow deposits could be worked profitably by stripping away the top unfrozen organic layers through either ground sluicing or mechanized scraping. Compared to drift mining, the methods used in open-cut mining created more of a lasting impact on the landscape, especially with the transition from relatively manual techniques to the introduction of large machines. Most of the landscape features created from the initial techniques of ground sluicing, shoveling-in and derricking have been reworked by steam shovels, drag lines and bulldozers, creating a landscape of widespread linear trenches, mounds and churned-up overburden.

Within the open-cut mining landscape, waste material tends to be the dominant feature, due to the large amount of overburden removed during extraction. Ground sluicing and horse scraping were the original methods used to remove the layers of overburden from the shallow bedrock floor. Using this method, miners would fill a water battery or boomer dam to its full capacity then open a gate, releasing a torrent rush of water over the surface of the mining area. This flow of water softened and loosened the surface material, allowing for easier removal of the overburden. Horses and mules pulled small capacity scraper buckets across the softened surface of the shallow placer as miners directed the animals to dumps away from the activity areas. As new technologies made their way into the Fairbanks district traditional ground sluicing and horse scraping were replaced with larger capacity steam driven scraper buckets and bulldozers. Found on the surface, these pieces of equipment play a role in defining the open- 
cut mining landscape. Penstocks, water batteries, sluice boxes, derrick buckets and long toms are all features of probable open-cut operations, but the most indicative is the presence of scraper buckets, bulldozer treads and hydraulic piping which found primary employment at open-cut plants (see Figure 6.11).

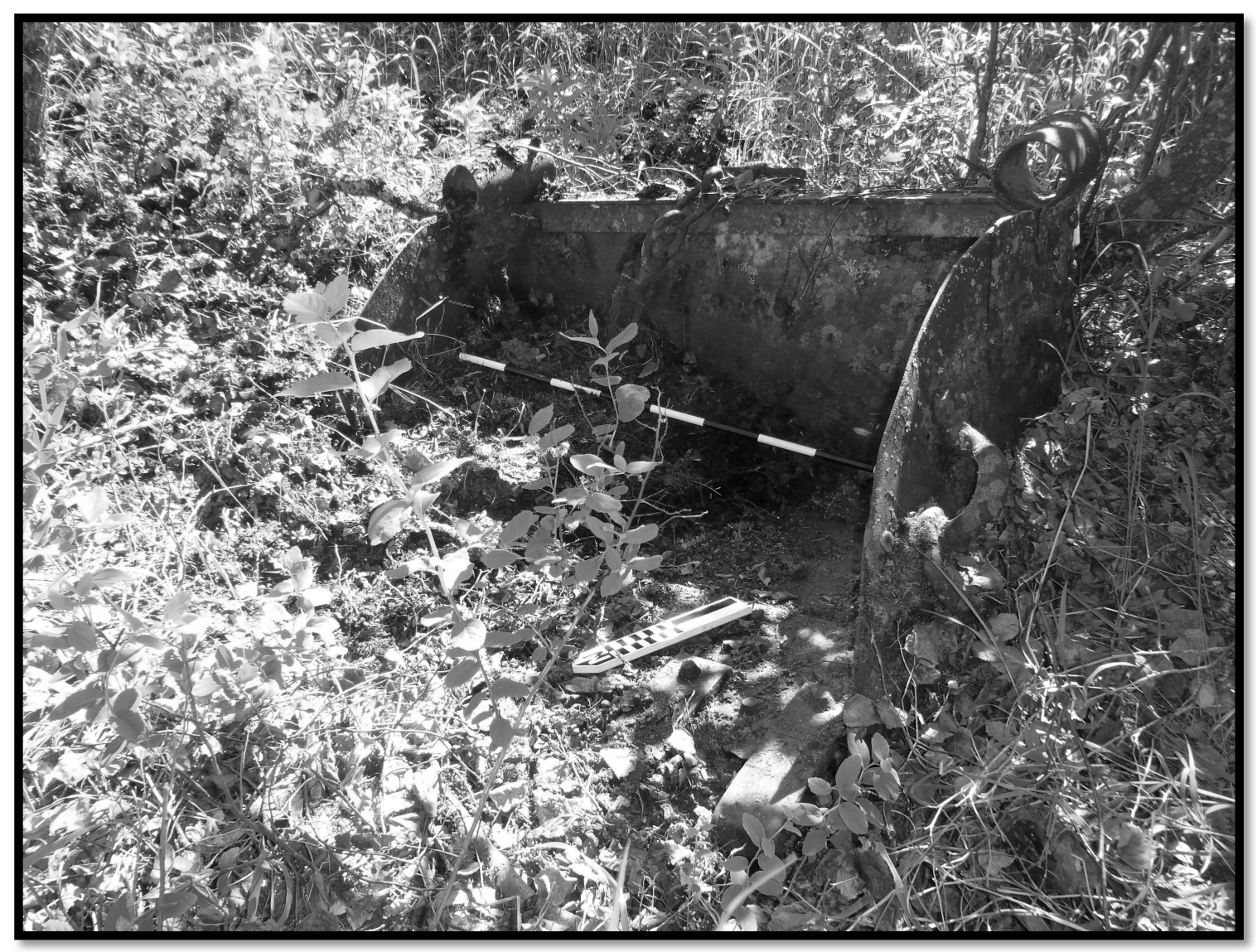

Figure 6.11: Slip scraper bucket at Cleary Creek. (Anderson: 2012)

These steam-scraping operations were arranged on the surface in a manner similar to drift mining. Both mining techniques utilized a gin pole as an anchor for hoisting, pulling the paydirt and waste material towards the mast. This hoisting method created the short-lived winter dumps of alluvium in drift mining, as well as conical overburden piles in the open-cut mines. The conical overburden piles are examples of a landscape by addition, a landscape defined 
by waste matter that tells a story of development. ${ }^{6}$ As mining activity moved within the shallow deposit, new gin poles were erected and new piles of overburden were built-up as the operation continued (see Figure 6.12).

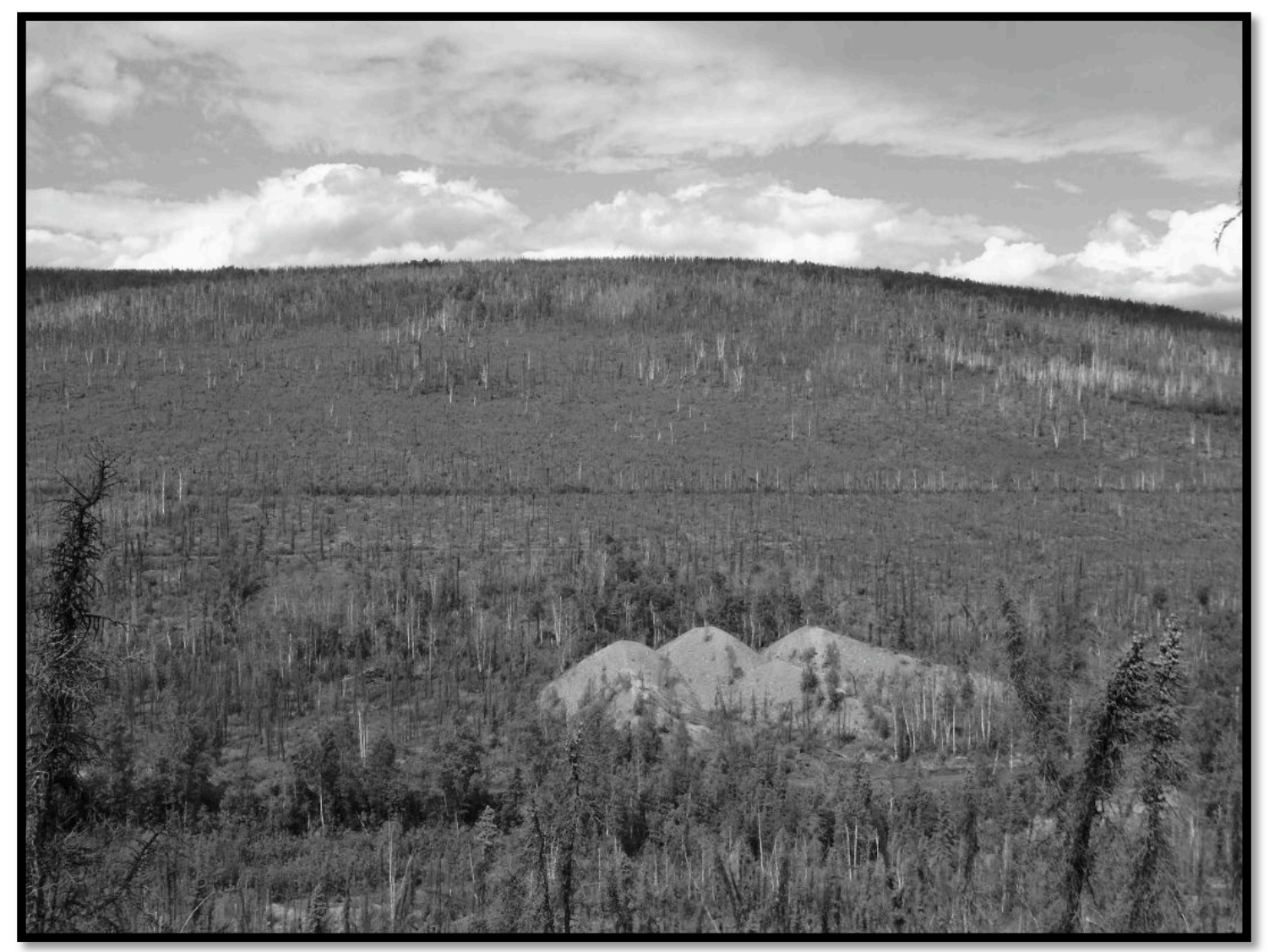

Figure 6.12: Overburden piles in the foreground show the "Landscape by Addition" while in the background, ditches signify the need for water at the Kokomo Creek site (Baeten: 2011)

Compared to the nearly uniform surface development patterns of drift mining, open-cut mining produced a greater diversity of surface arrangements and mining techniques. The initial rush of prospectors quickly exhausted the rich, deep deposits with inefficient and expensive methods. These methods experienced little technological change or dramatic innovation. On the other

\footnotetext{
${ }^{6}$ Richard Francaviglia, "Hard Places, Reading the Landscape of America's Historic Mining Districts", American Land and Life Series (lowa City: University of lowa Press, 1991) 137.
} 
hand, open-cut mining lasted longer; new technologies and modified mining techniques allowed for profitable returns from the lower grade deposits that are still being exploited today. As Fairbanks transitioned from a predominantly drift mining district to an open-cut one, many historic landscape features were obliterated. Successions of mining created a landscape in flux; bulldozers and backhoes pushed down and tore up the early signs of development and replaced them with new patterns that reflect the technological maturation of the open-cut system.

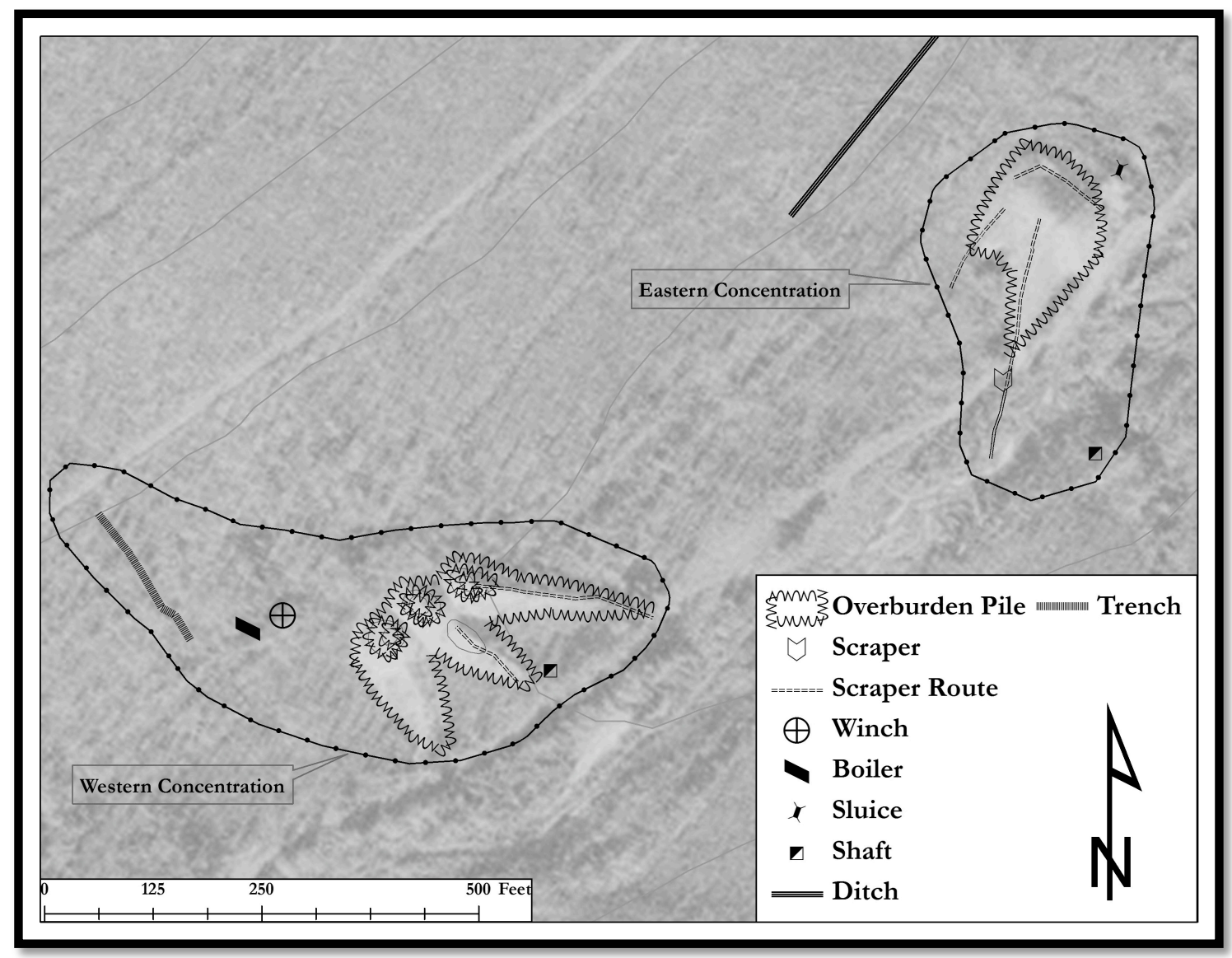

Figure 6.13: Kokomo Creek Open-cut Site (Baeten: 2012)

The most distinctive open-cut site located in 2011 was found at Kokomo Creek, in the eastern extent of the Fairbanks Mining District (see figure 6.13). This site consists of four large, conical overburden piles that dominate the 
surrounding landscape. The site is divided into eastern and western concentration, with the eastern concentration likely being the site's original development area. In comparison to both the drift mining and dredging sites (described later), whose landscape footprints are only visible at site, the overburden piles of the Kokomo Creek site are viewable even from aerial imagery, further denoting the intense surface development on the landscape.

Large waste piles make up the core of the Kokomo Creek site, but the associated pieces of equipment coupled with the landscape features, help in defining the site as an open-cut mine. Located to the south of the eastern concentration's overburden pile is a scraper bucket, found in situ with its historic conveyance route running up the side of the overburden pile (see figure 6.14). This overburden pile has three distinct conveyance routes, running from the outer extent of the waste pile towards its center apex, where a gin pole would have been located. These transportation patterns help with the interpretation of the site, making the operation of the scraper less opaque. In addition to the scraper bucket, a metal sluice is found on the eastern side of this overburden pile. During the site's operation, the paydirt would have been pulled up the overburden piles and then mechanically dumped into the sluice, where the paydirt would have been washed. 


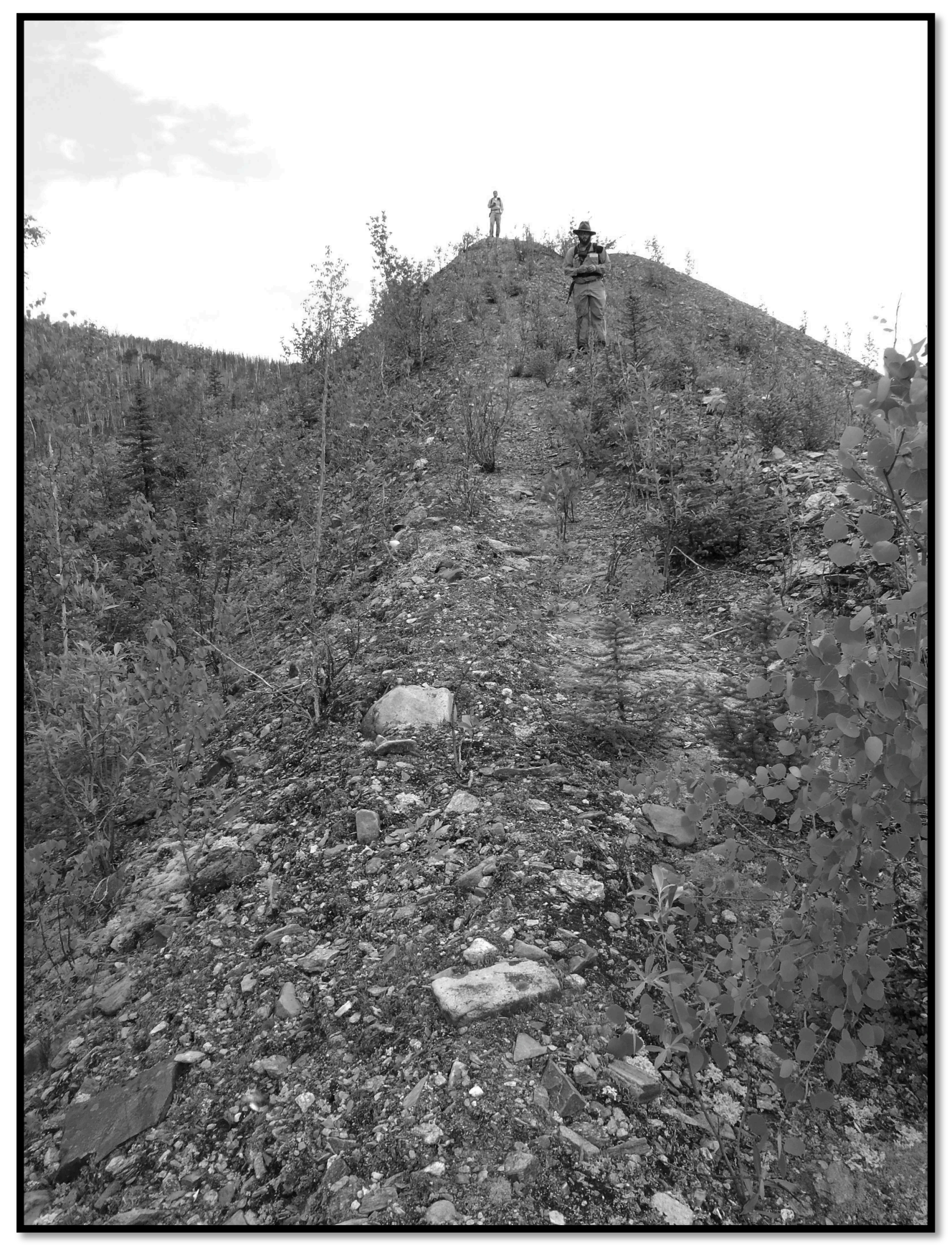

Figure 6.14: Crew members stand on the conveyance route of the scraper in the Eastern Foci Peterson: 2011)

The western concentration contains the remaining three overburden piles, which also show the distinctive conveyance routes used by the scraper buckets. These three overburden piles are more elongated than the eastern concentration, 
spreading towards Kokomo Creek, with the apex of the pile located furthest from the creek. Located upslope and northwest of the overburden piles are a locomotive boiler and a steam powered winching engine (see Figure 6.15). These pieces of equipment powered the steam scraper operation, the locomotive boiler fueling the adjacent engine, whose multiple pulleys dragged the scraper bucket from the creek towards the gin pole at the top of the overburden piles. These pieces of machinery suggest that the western concentration was the later producing development, as the eastern concentration is devoid of any power source.

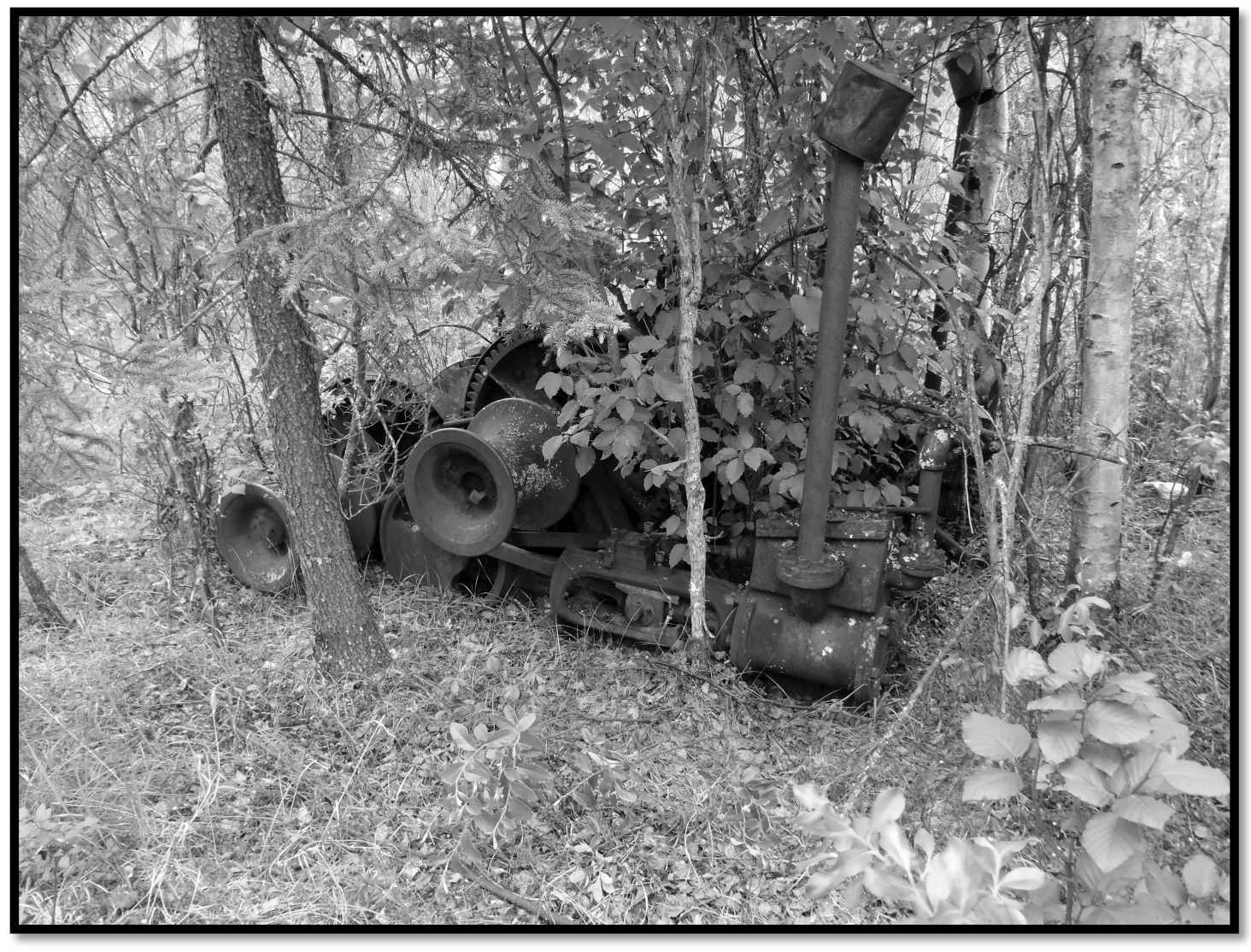

Figure 6.15: Steam powered winching engine (Baeten: 2011)

The landscape patterns of the Kokomo Creek site fit the distinctive patterns seen in the open-cut mining phase in the Fairbanks District. The conical overburden piles paired with the scraper bucket and its conveyance routes, along 
with the locomotive boiler and steam powered winching engine makeup the defining landscape features of the Kokomo Creek site, features that characterize the open-cut mining technique of ground scraping.

The succession of mining technologies that dominated the open-cut

phase in Fairbanks continues upstream and east of the Kokomo Creek site, where miners are actively engaged in an ongoing open-cut operation. These miners are using technologies like suction dredges, excavators and bulldozers to remove and wash the same low-grade deposits worked by the ground scrapers employed during the open-cut phase.

\section{Phase 3: Dredging}

Roughly thirty years after the first drifts were tunneled northeast of Fairbanks, a fleet of massive dredges reworked the abandoned mines, mine waste and low-grade placer deposits, profiting through improved technologies and the inefficient gold recovery of the past. The creek workings that were exploited with pick, pan and gophering at the turn of the century were reworked with bucket and trommel during the dredging boom of the 1930s. Similar to open-cut mining, the dredges created a new landscape by modifying an historic one. Ditches, ponds and especially tailings dominate the dredging landscape. As dredges reworked the creek bottoms the waste material passed through the dredge and was stacked in neat rows like worm castings that universally characterize the dredging landscape (see Figure 6.16). 


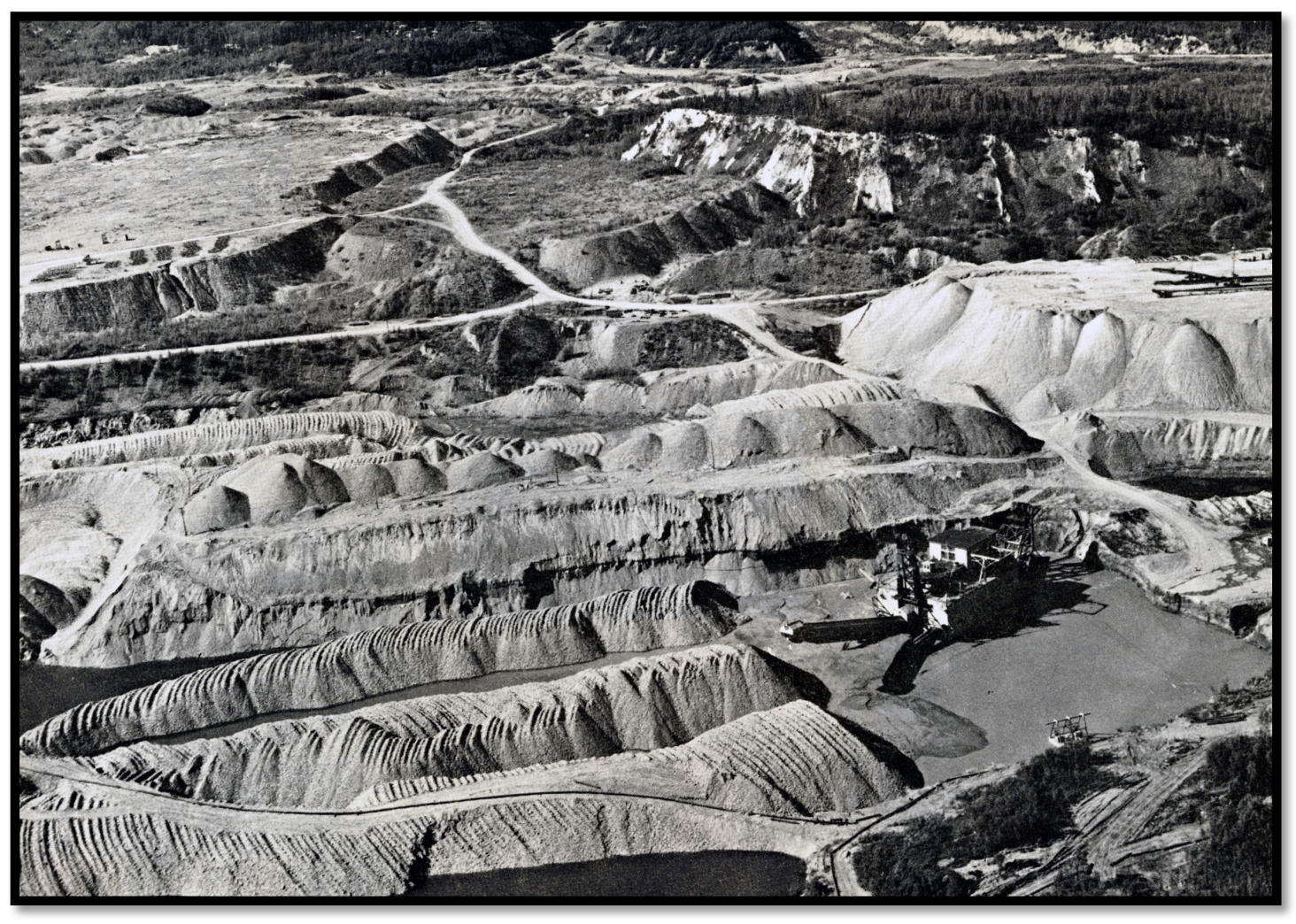

Figure 6.16: Typical Dredge Landscape in Ester (Boswell, 1979:85)

Compared to drift mining and open-cut operations, the surface arrangement of a dredging operation contains fewer structures and less equipment. This is due mainly to the portable nature of the dredge, as well as its operation both as an excavator and washing plant, limiting the amount of ancillary devices needed at the surface for the dredge to operate. Primary ancillary structures and features associated with dredging include: braided cable tie downs, ditches, ponds, hydraulic piping, trommel screens, small powerhouses, machine and blacksmith shops and utility poles.

The intense dredging activity of the 1930s made a lasting effect on the landscape, an impact more striking than any mining activity previously conducted. In addition to working new ground, the dredges actively worked the previously mined drifts of the early 1900s (see Figure 6.17). This reworking consisted of thawing the overburden with cold water, stripping off the top layers 
of debris by hydraulicking and with draglines, and then creating an artificial pond for the dredge to operate in. During the preparatory work previously constructed ditches, drifts and shafts were often obliterated, and occasionally entire mining camps succumbed to the magnitude of the Fairbanks Exploration Co.'s dredging operation, as seen in Chatankia, where an entire camp was consumed by the Fairbanks Gold Dredge No.3.

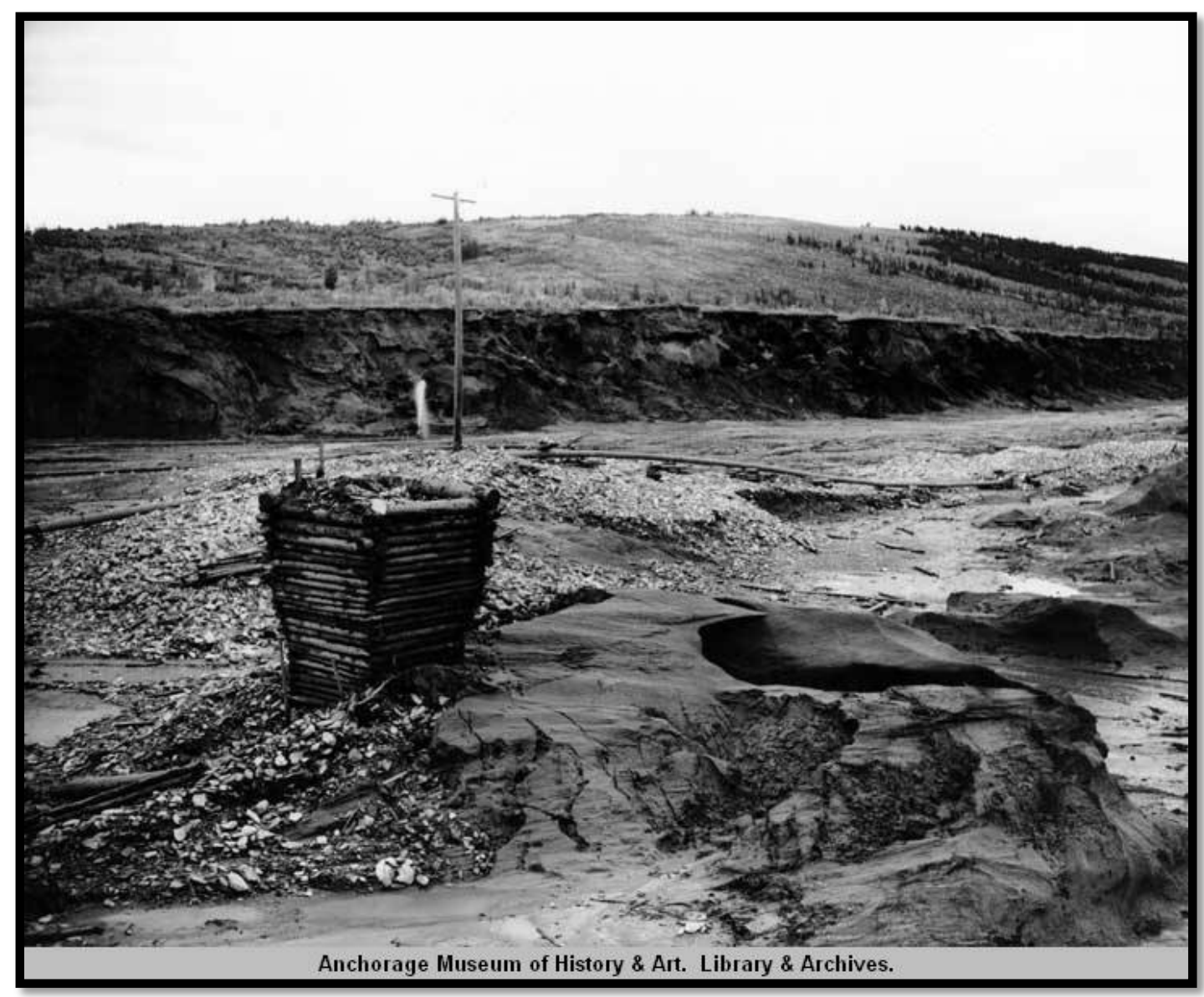

Figure 6.17: Thawed and prepared dredging area, showing intact cribbed shaft from prior drifting (Courtesy Anchorage Museum of History \& Art, Ickes Collection, Accession \#B75-175-259)

The defining pattern of tailings within the dredging landscape can become obscured by vegetation and erosion, depending on the age and intensity of dredging activity. Less intense and older dredging areas frequently resemble only a widened stream bed with interspersed mounds, rather than the lunar 
landscape that so often characterizes an area that has been thoroughly dredged (see Figure 6.18). Although the Fairbanks Mining District is home to a number of remaining dredges, complete dredges within the mining landscape are an atypical component compared to the larger proportion of discarded dredging equipment. Found in a greater abundance within the dredging landscape are individual pieces of the dredge; broken trommel screens, complete buckets or bucket lips and worn down spuds are often the only obvious remains these behemoths left in their wake. In the more obscure dredging landscapes, these remains assist in the eventual characterization of the workspace as a dredging one.

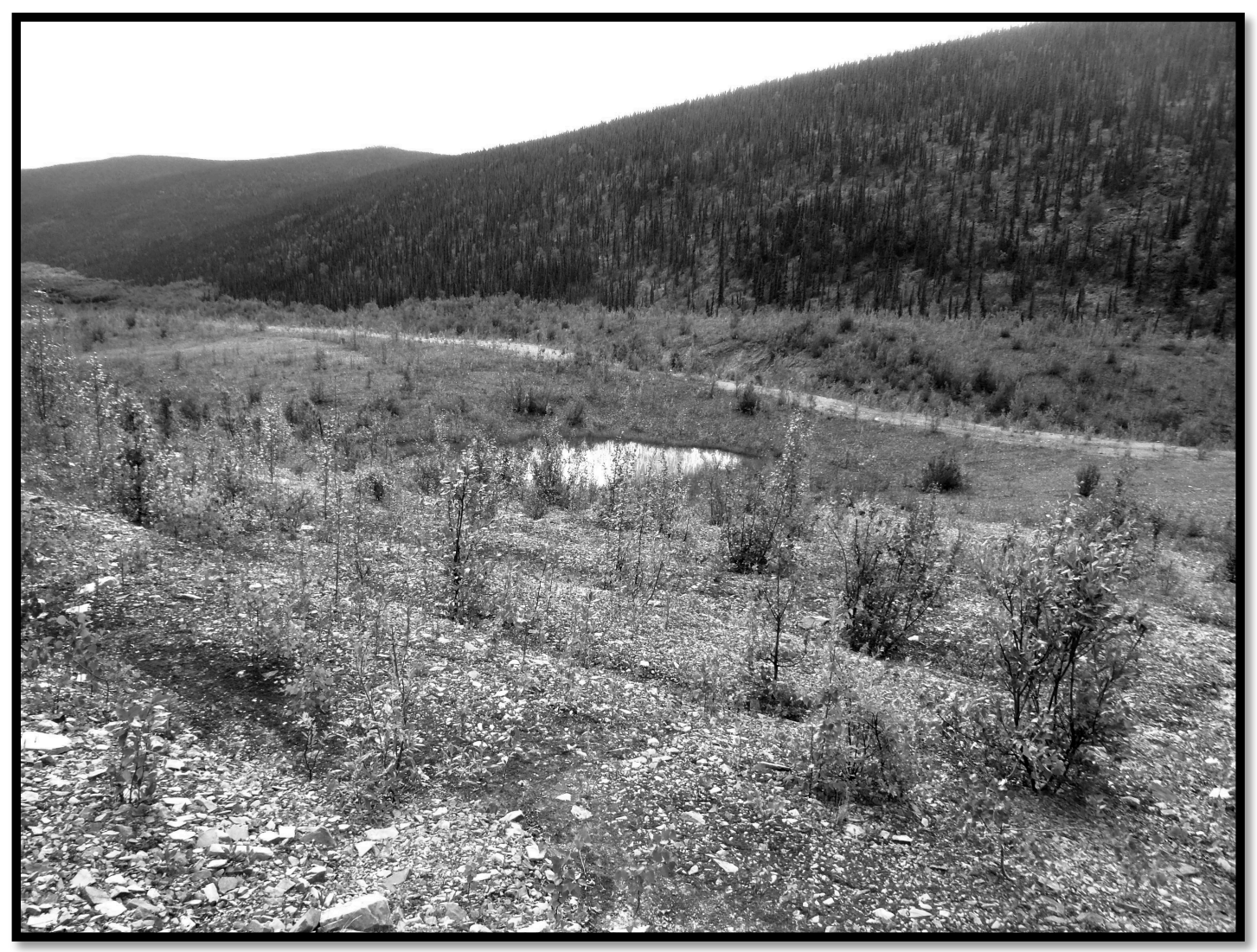

Figure 6.18: Dredged landscape at Fairbanks Creek. (Tinoco 2012)

The Fairbanks Exploration Co. began dredging on Gilmore Creek in 1928, exploiting the low-grade shallow deposits found near the confluence with Pedro 
Creek. Near this location a dredging site was identified in 2011 (see Figure 6.19). This site, although fairly obscure on the surface, shows some of the distinctive landscape features that help distinguish a dredging site from other open-cut mining sites.

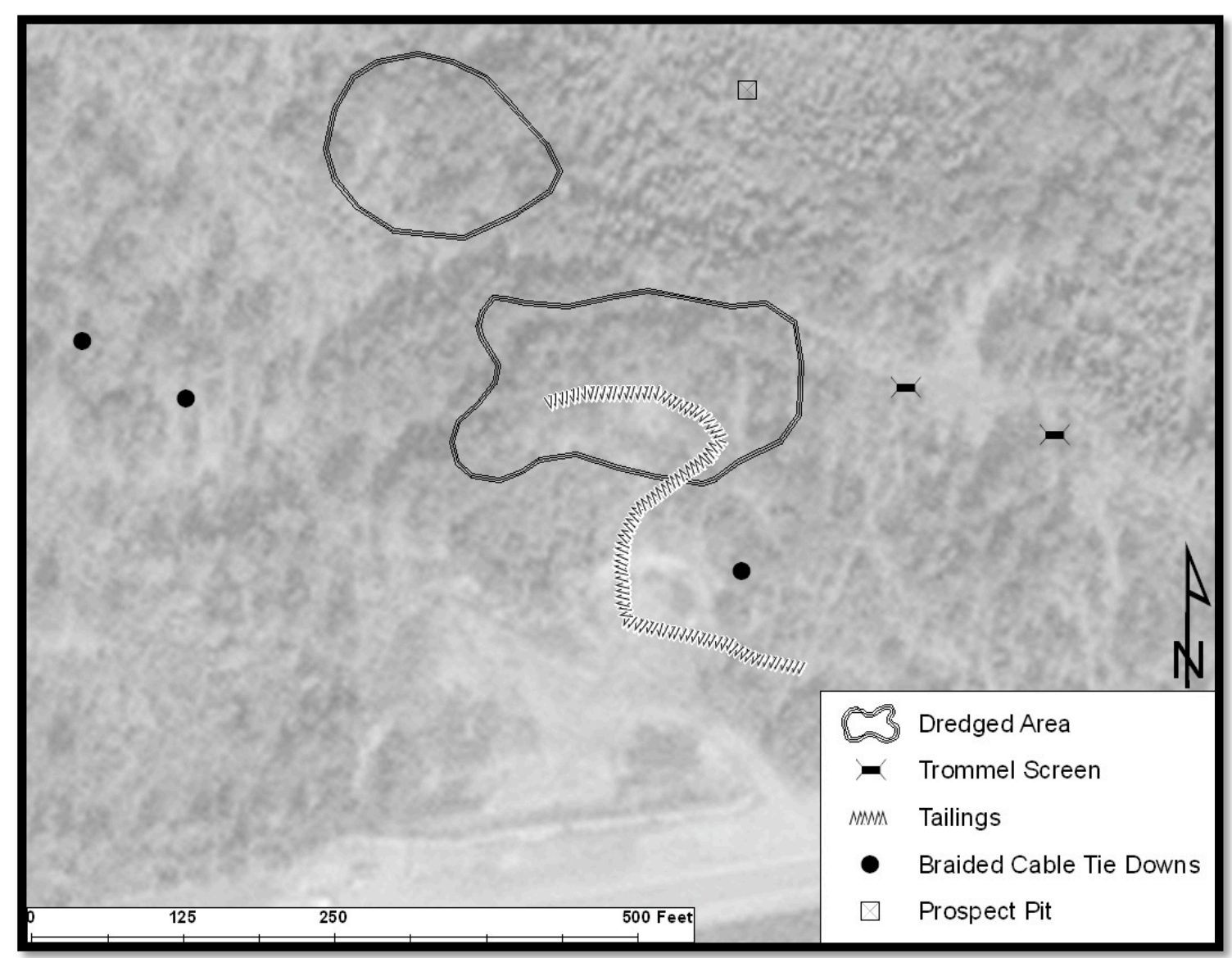

Figure 6.19: Gilmore Creek Dredging Site (Baeten:2012)

The core of the Gilmore Creek site is centered around two clusters of dredging activity, defined by disturbed soils and interspersed tussocks. These landscape features are fairly similar to the surface features seen in many opencut mining sites, adding to the relatively ambiguous nature of many dredging landscapes in Fairbanks. However, in addition to the clusters of disturbed earth, small linear berms of tailings are present, notably in the southern-most cluster of dredging activity. These tailings are heavily overgrown, but retain the neat linear 
arrangement that often characterizes dredge tailings on the landscape (see Figure 6.20).

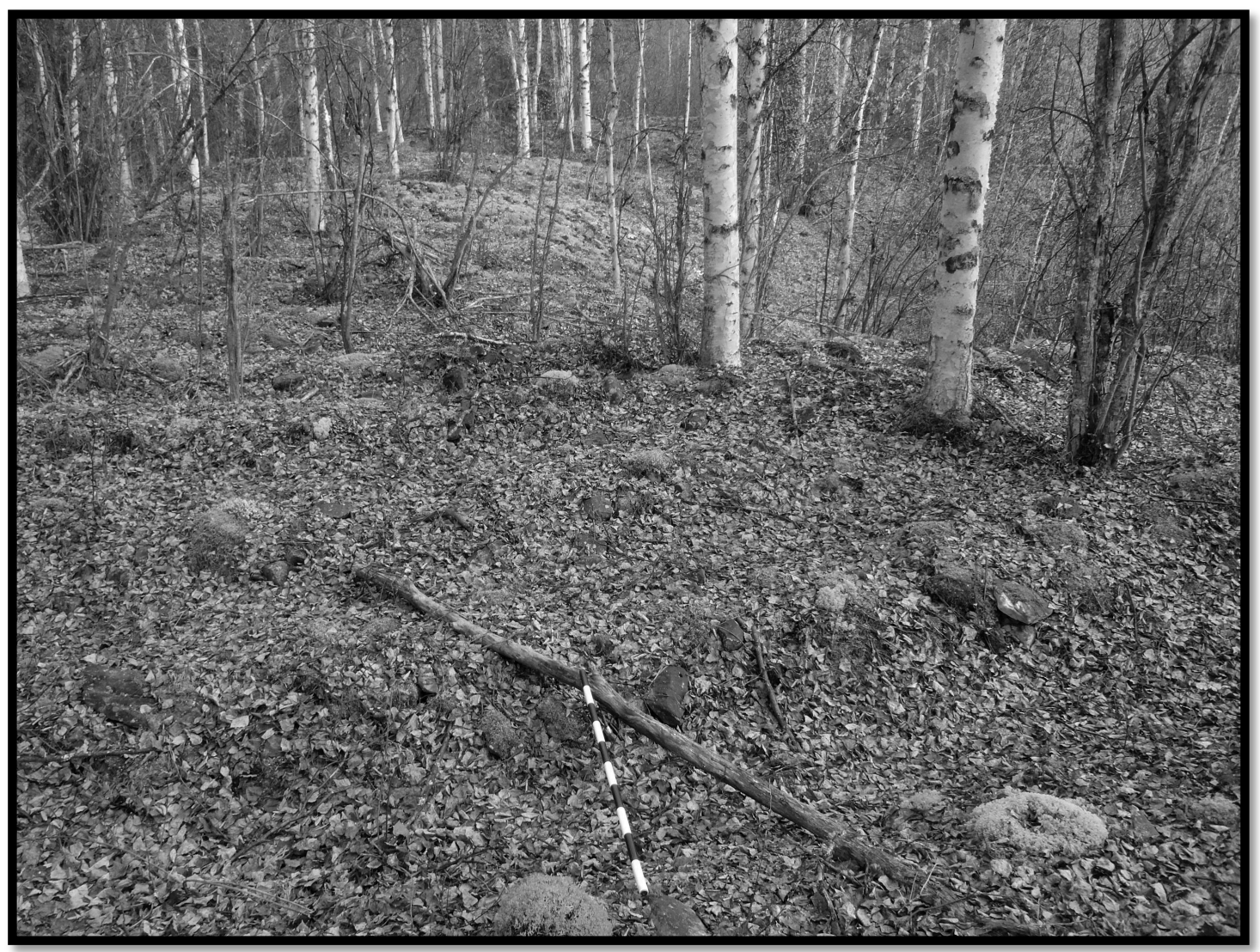

Figure 6.20: Linear dredge tailings (Peterson: 2011)

In addition to the tailings, trommel screens were located in the eastern extent of the site (see Figure 6.21). Dredges used trommels to classify paydirt and after periods of use, the screens within the trommel would become damaged and need to be replaced, with the damaged screens being swapped out and discarded on site. The trommel screens, combined with the tailings, are the most distinctive feature of the site and lend to the characterization of this mining landscape as a dredging one. In addition to the trommel screens, braided cable tie downs are located in rows within the southern edge of the site. These rows of braided cable show the movement of the dredge down the creek; the braided 
cable tie downs were used in conjunction with the dredge's spud to help keep the dredge from drifting within its pond while the buckets were digging.

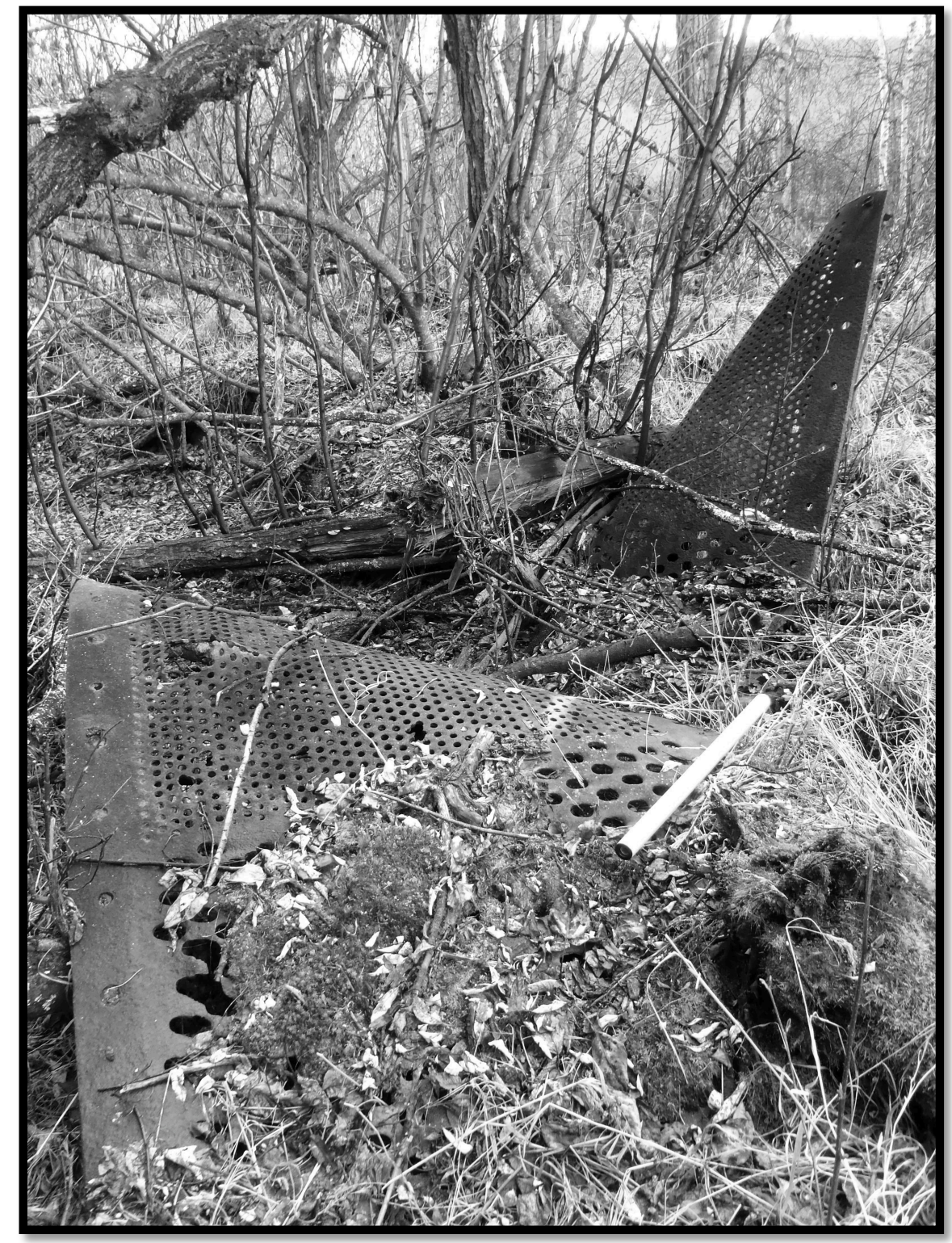

Figure 6.21: Damaged trommel screens (Baeten: 2011)

Much of the vegetation has reestablished itself at the Gilmore Creek site, making the landscape difficult to interpret; but when viewed in a GIS, the landscape patterns in the data begin to become apparent. The ' $S$ ' shaped pattern of the tailings and the arrangement of the braided cable give clues to 
where the dredge was situated and what direction it was moving. These landscape patterns provide further clues to the dredges operation and assist in the site's interpretation.

\section{Recognizing the Pattern}

The Fairbanks Mining District experienced concentrated placer mining activity over a span of nearly 100 years, mining activity that can be grouped into three phases. This activity created archaeological features that are evident in both material culture and within the landscape in the form of abandoned machinery, structures, pits, cuts and overburden piles; telltale signs of the historic technologies and mining systems. The miners left tools that reflect a chronology of technological change and economic development; as increased funds flowed into the interior, miners switched from simple wood-fired boilers producing steam for thawing, hoists and steam shovels, to larger, sophisticated diesel and electric powered engines, bulldozers and dredges. Recognizing these technological changes help us better understand the origin of the surrounding landscape features found in these historic workspaces.

Change is also evident in surface features, showing the progression from prospecting to production. Prospecting features are seen throughout the landscape in the older hand-dug pits and more extensive bulldozer cuts, while the mine production and development features are found within the piles of overburden and structures at the mine site. The landscape features reflect the mining methods and technologies used in placer operations and show patterns of prospecting and development within the workspace. These patterns show the extent of human activity within the mining workspace and signify the lasting impression these miners made in the Fairbanks Mining District. 
"There is no better way of winning knowledge than to give away the little that you have; all that we all of us know is but a small matter. The worst of all waste is the waste of

experience"

The Stamp Milling of Gold Ores, T.A. Rickard 1903

\section{Chapter 7: Summary and Conclusions}

In 1902 a down on his luck prospector named Felice Pedroni located gold near a fledgling trading post on the banks of the Chena River. This discovery spurred a gold rush, with experienced miners from the Klondike congregating in the creeks and speculators devising plans for quick profits near the trading post, later named Fairbanks. Although their relationship was often confrontational, the miners and speculators shared an underlying commonality, an unwavering optimism for the small mining camp. These founders remained committed to the Fairbanks camp even when faced with poor returns from the gold fields, food shortages and desolate living conditions. Their dedication paid off; in two years time the small mining camp was a bustling town and a top placer producer in Alaska. However, the success of the Fairbanks Mining District was not due to sheer optimism; instead, the success was the result of: experienced miners working an extensive placer deposit, an improved system of transportation allowing for higher capacity technologies at the mines, and a willingness to alter mining methods as the grade and depth of the placer deposits changed.

Pedroni's discovery of gold in Fairbanks was well timed, roughly 15 years after gold was discovered near the Alaska-Yukon border on the Fortymile River. Miners working the Fortymile, and subsequently in the Klondike, were faced with environmental conditions previously unknown to placer mining in the West, specifically permafrost. These early Klondike miners adapted to the environmental challenge through trial and error, developing technologies and mining methods that allowed for the efficient extraction of gold from alluvium 
within frozen ground. The miners brought these skills and technologies with them from the Klondike and applied them to the deep frozen deposits in Fairbanks. This technology, such as steam points, gave the Fairbanks Mining District a distinct advantage over previous Arctic gold rushes, where miners new to the arctic dominated the placer fields, using a system of trial and error while they slowly developed the Klondike System.

The steam points accelerated the driving of shafts in the Fairbanks mines, but due to an inadequate system of transportation and a lack of capital investment, the miners relied on relatively small capacity, portable equipment, limiting the amount of paydirt that could be taken out of the shafts and washed for a profit. Starting in 1905, the construction of the Tanana Valley Railroad began. This railway connected the mines by rail to Fairbanks, providing the miners with an avenue to affordably receive larger capacity boilers, hoists and machinery and securely ship the pay dirt back to Fairbanks for safe keeping. The introduction of improved technologies ignited the development of the Fairbanks placer fields, increasing the total output of the mines from $\$ 600,000$ to $\$ 6,000,000$ in the course of a year.

By 1909, the mining boom that put Fairbanks on the map was in decline; the larger capacity technologies performed so well that after only four years, the highest-grade deposits were nearly exhausted. As the district began its decline, the remaining miners turned their attention to both lode deposits and the shallow low-grade placer deposits throughout the region. New technologies, like steam shovels, were brought into the area that could extract and process the low-grade deposits at a profit, but the district continued to decline. For the next fifteen years the Fairbanks Mining District produced fractions of prior year production, until 1923 when large dredges began operating in the district (see Figures 7.1 and 7.2). These dredges reinvented the Fairbanks district, as the dredges shoveled through the previously worked mines and low grade deposits, yielding high profits until the early 1960 s. 


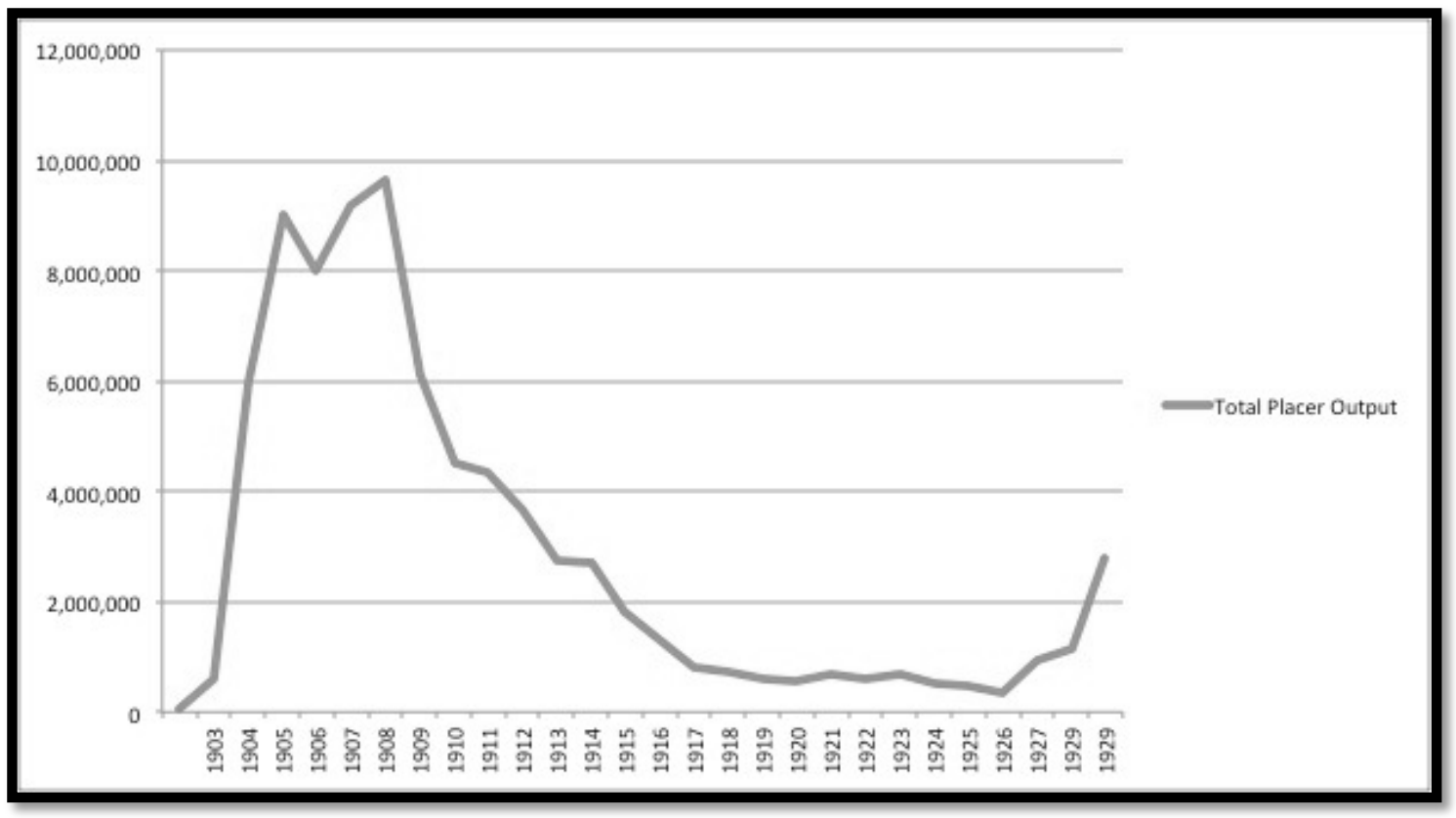

Figure 7.1: Total placer output from 1903-1929 (Digitized from Hill, 1933)

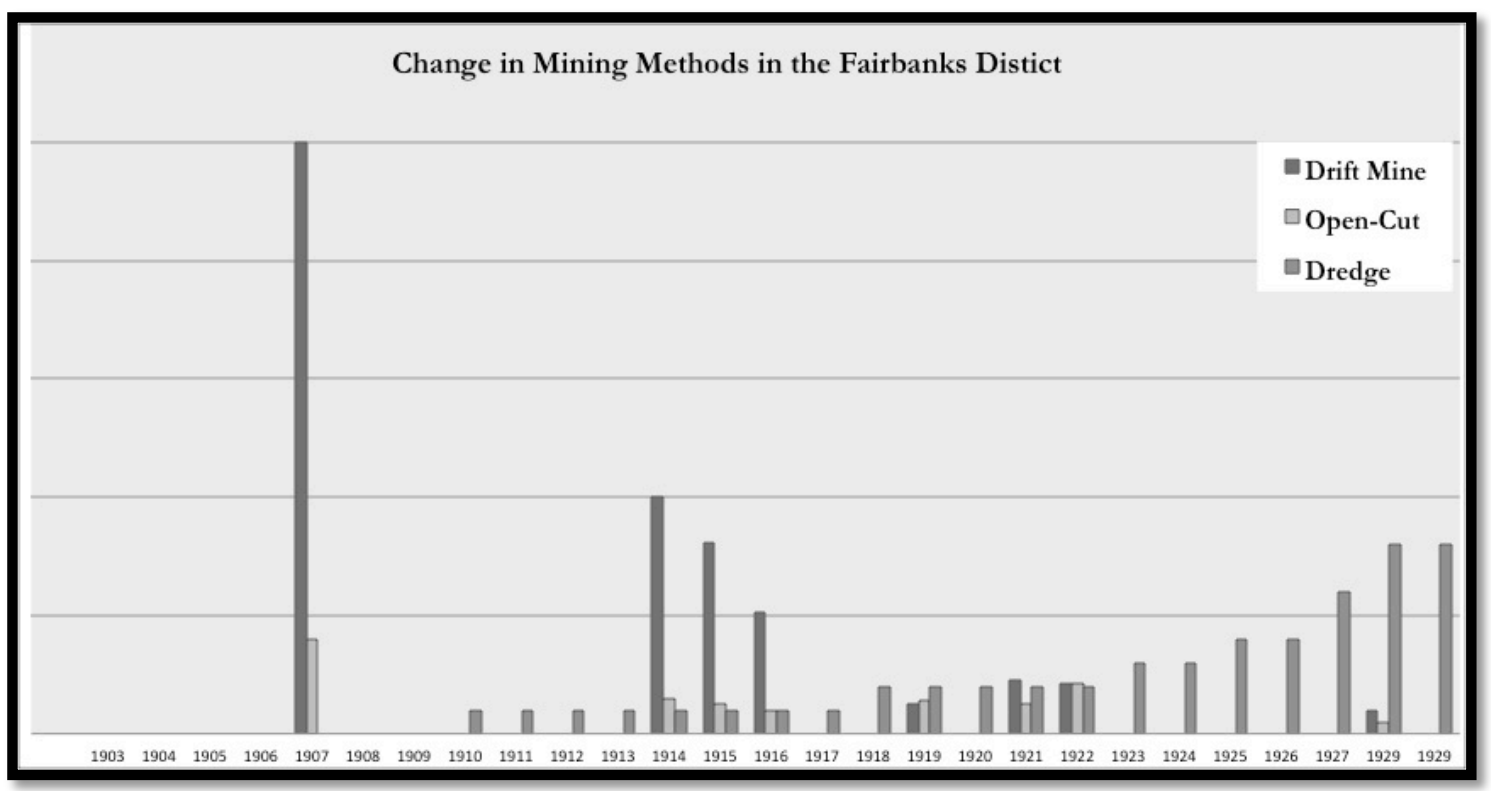

Figure 7.2: Chart shows the eventual shift from drift mining to open-cut mining and dredging (Digitized from USGS Bulletins and Alaska Annual Reports)

Owing to the breadth of the placers within the Fairbanks Mining District, open-cut mining continues today, but on a much smaller scale than in the 
district's boom years. Successive phases of mining helped Fairbanks stay a top placer producer for over 60 years, and the extent of this mining activity remains evident on the cultural landscape. Elements of prospecting dominate the majority of landscape features, showing a change from older, shovel-dug pits to the deep, modern holes and trenches dug by excavators. Intricate systems of ditches also show a change from hand dug to mechanized and serve as a reminder of the vernacular engineering undertaken by the miners, as they transformed an arid landscape into one with enough concentrated water to wash the alluvium. Additional signs of mine development including buildings, structures and machinery provide tangible evidence of the financial expenditure that tied these miners to their workspace.

Although the Fairbanks Mining District was not the first producer of placer gold it was the biggest. When the last dredges ceased operating, the Fairbanks Mining District had accounted for nearly $40 \%$ of the total Alaskan gold production to date. ${ }^{1}$ The success of the Fairbanks district was due not to an extremely high-grade deposit, nor was it the result of any unique mining method or technology; instead, the success of the district was due to an expansive lowgrade deposit, the resiliency of the early miners and the maturation of mining methods and technological systems. Similar to Aesop's tortoise, the Fairbanks district was always trying to catch-up; placer mining in the District had a relatively late start, miners used outdated technologies due to an insufficient transportation system, and full scale dredging began only after years of decline, but as the rich gold fields of the Seward Peninsula tired out the Fairbanks district pushed on, slowly out producing all other districts.

\footnotetext{
${ }^{1}$ Edward Cobb, "Placer Deposits of Alaska”, USGS Survey Bulletin 1374 (Washington: GPO, 1973) 128. Figure given is a production value up to 1961.
} 


\section{Works Cited}

Anonymous. "Mining News". The Engineering and Mining Journal Vol. XC, 09-171910, 1910.

Mining News, "Lemons-Alaska". The Engineering and Mining Journal, Vol. 90, 12-17-1910, 1910.

Berton, Pierre. The Klondike Fever. New York: Alfred A. Knopf, 1959.

Boswell, John C. History of the United States Smelting, Refining and Mining Company. Fairbanks: Mineral Industries Research Laboratory, 1979.

Bowie, Augustus J. A Practical Treatise on Hydraulic Mining in California. 10th Edition. New York: D. Van Nostrand Co., 1905.

Brooks, Alfred. Blazing Alaska's Trails. Washington: University of Alaska and the Arctic Institute of North America, 1953.

. "Report on Progress of Investigations of Mineral Resources of Alaska in 1904. USGS Bulletin No. 259, Washington: Government Printing Office, 1905.

. "Alaska". The Engineering and Mining Journal, Volume 79, 1905.

. "The Mineral Resources of Alaska, 1908", USGS Bulletin 37.

Washington: Government Printing Office, 1909.

. "Mineral Resources of Alaska, Report on Progress of Investigations in 1913". United States Geological Survey (USGS) Bulletin 592, Washington: Government Printing Office, 1914.

. "Mineral Resources of Alaska, 1916", USGS Bulletin 262, Washington:

Government Printing Office, 1916.

. "Mineral Resources of Alaska, Report on Progress of Investigations in 1920". USGS Bulletin 722, Washington: Government Printing Office, 1922. 
Cobb, Edward H. "Placer Deposits of Alaska". USGS Survey Bulletin 1374. Washington: Government Printing Office, 1973.

Cole, Dermot. "Fairbanks, A Gold Rush Town that Beat the Odds". Epicenter Press: Fairbanks-Seattle, 1999.

Cole, Terrence. Crooked Past: The History of a Frontier Mining Camp: Fairbanks, Alaska. Fairbanks: University of Alaska Press, 1984.

Cook, Donald J. "Placer Mining in Alaska". Mineral Industry Research Laboratory Report No. 65. Fairbanks: University of Alaska - Fairbanks, 1983.

Editorial Correspondence. The Engineering and Mining Journal, Volume 80, 0902-1905, 1905.

Ellis, Hubert Ingersoll. Mining Methods at Fairbanks. Unpublished Thesis: University of Washington, 1915.

. "Development Methods at Fairbanks". The Engineering \& Mining Journal, Volume 99, Number 24, 06-12-1915, 1915.

. "Thawing Methods at Fairbanks". The Engineering \& Mining Journal, Volume 100, Number 1, 07-03-1915, 1915.

Ellsworth, C.E. "Placer Mining in the Fairbanks and Circle District". Mineral Resources of Alaska, Report on progress of investigations in 1911, USGS Bulletin 520-H. Washington: Government Printing Office, 1912.

Feldman, Carol. "The Chisana-Gold Hill Landscape", A Cultural Landscape Report prepared for the National Park Service-Wrangell St. Elias Park and Preserve. University of Texas at Arlington, 1998.

Francaviglia, Richard. "Hard Places, Reading the Landscape of America's Historic Mining Districts". lowa City: University of lowa Press, 1991. Gardner, Eugene D. "Placer Mining in the Western United States". U.S. Bureau of Mines Information Circular 6788. Washington: Government Printing Office, 1935.

Griffith, S.V. Alluvial Prospecting and Mining. London: Pergamon Press, 1960. 
Harris, A.C. Alaska and the Klondike Gold Fields. Toronto: Coles Publishing Co., 1897.

Hildebrandt, James C. History of Placer Mining in Alaska. Fairbanks:

Unpublished Thesis, 1917.

Hill, James M. "Lode Deposits of the Fairbanks District, Alaska". USGS Survey

Bulletin 849-B. Washington: Government Printing Office, 1933.

Hittell, John S. Mining in the Pacific States of North America. San Francisco: H.H. Bancroft \& Co., 1861.

Hunt, William R. North of $53^{\circ}$, The Wild Days of the Alaska-Yukon Mining

Frontier 1870-1914. New York: MacMillen Publishing Co. Inc, 1974.

International Correspondence School Editorial Staff. "Steam Boilers: Settings,

Trials, and Designs". International Library of Technology Vol. 357.

International Textbook Company: Scranton, 1924.

International Correspondence School. A Treatise on Metal Mining, Volume II.

Scranton: The Colliery Engineer Co., 1899.

Jackson, Chas. F. "Small Scale Placer-Mining Methods". Bureau of Mines

Technical Paper 591. Washington: Government Printing Office, 1938.

Lewis, Robert S. Elements of Mining. New York: John Wiley \& Sons, Inc, 1933.

Lindstrom, C.B. Steam Boilers and Equipment. International Textbook Company:

Scranton, 1928.

MacDonald, Eoin H. Alluvial Mining, The geology, technology and economics of

placers. London: Chapman \& Hall, 1983.

Matheson, Janet and Haldemen, F. Bruce. "Historic Resources in the Fairbanks

North Star Borough". A Report of the Fairbanks North Star Borough

Planning Department. Fairbanks: The Borough, 1981.

Parker, Genevieve. The Evolution of Placer Mining Methods in Alaska.

Fairbanks: Unpublished Thesis,1929.

Peele, Robert. Mining Engineers' Handbook. New York: John Wiley \& Sons, 1927. 
Prindle, L.M. "Gold Placers of the Fairbanks Mining District, Alaska".

Contributions to Economic Geology, USGS Bulletin No. 225. Washington: Government Printing Office, 1903.

" "Gold Placers of the Fairbanks District, Alaska". USGS Bulletin No. 225,

Series A Economic Geology, 33. Washington: Government Printing Office, 1904.

. "The Fairbanks and Rampart Quadrangles Yukon-Tanana Region, Alaska". USGS Bulletin No. 337. Washington: Government Printing Office, 1908.

. "A Geologic Reconnaissance of the Fairbanks Quadrangle, Alaska". USGS Bulleting No. 525. Washington: Government Printing Office, 1913.

Prindle, L.M. and Katz, F.J. "The Fairbanks Gold Placer Region". USGS Bulletin No. 379. Washington: Government Printing Office, 1908. . "A Geologic Reconnaissance of the Fairbanks Quadrangle, Alaska". USGS Bulletin 525. Washington: Government Printing Office, 1913.

Purington, Chester Wells. "Methods and Costs of Gravel and Placer Mining in Alaska”. USGS Bulletin No. 263. Washington: Government Printing Office, 1905.

Rickard, T.A. Through the Yukon and Alaska. San Francisco: Mining and Scientific Press, 1909.

Riggs, Thomas J. "Report of the Governor of Alaska". Reports of the Department of the Interior, For the Fiscal Year Ended June 30 1919, Volume II. Washington: Government Printing Office, 1920.

Robe, Cecil. The Penetration of an Alaskan Frontier: The Tanana Valley and Fairbanks. Yale University: Unpublished Dissertation, 1943.

Savage, Eros M. Prospecting for Gold and Silver. New York: McGraw-Hill, 1934. Smith, Philip S. "Mineral Resources of Alaska, Report on Progress of Investigations in 1924". USGS Bulletin 783. Washington: Government Printing Office, 1926. 
"Mineral Resources of Alaska, 1927". USGS Bulletin 810. Washington:

Government Printing Office,1930.

. "Mineral Resources of Alaska, 1928". USGS Survey Bulletin 813.

Washington: Government Printing Office, 1930.

. "Mineral Resources of Alaska, 1929". USGS Bulletin 824. Washington:

Government Printing Office, 1932.

. "Mineral Resources of Alaska, Report on progress of investigations,

1935". USGS Bulletin 880. Washington: Government Printing Office, 1937.

. "Mineral Resources of Alaska, Report on Progress of Investigations

1936". USGS Bulletin 897. Washington: Government Printing Office, 1938.

Stewart, B.D. Annual Report of the Territorial Mine Inspector to the Governor of Alaska, 1920. Juneau: Alaska Daily Empire Print, 1921.

. Annual Report of the Territorial Mine Inspector to the Governor of Alaska, 1923. Juneau: Alaska Daily Empire Print, 1924.

. Mining Investigations and Mine Inspection in Alaska, Including assistance

to prospectors for the biennium ending March 31, 1933. Juneau, Territorial Printing Press, 1934.

Van Wagenen Theodore F. Manual of Hydraulic Mining for the use of The

Practical Miner. New York: D. Van Nostrand, 1880.

Williams, Catherine M., Reuther, Joshua D., and Bowers, Peter M. History of the Davidson Ditch, North of Fairbanks, Alaska. Unpublished report prepared for Fairbanks Gold Mining, Inc., 2003.

Wilson, Eugene B. Hydraulic and Placer Mining. New York: John Wiley \& Sons, 1900.

Wimmler, Norman L. "Placer-Mining Methods and Costs in Alaska". Bureau of Mines Bulletin No. 259. Washington: Government Printing Office, 1927.

Wolff, Ernest. "Handbook for the Alaskan Prospector". Mineral Industry Research Library. Fairbanks: University of Alaska, 1967. 
Young, George J. Elements of Mining. $3^{\text {rd }}$ Edition. New York: McGraw-Hill Book Company, 1932. 